\title{
molbank
}

Molecules from

Side Reactions

Printed Edition of the Special Issue Published in Molbank 
Molecules from Side Reactions 



\section{Molecules from Side Reactions}

Editor

Stefano D'Errico

MDPI $\bullet$ Basel $\bullet$ Beijing $\bullet$ Wuhan $\bullet$ Barcelona $\bullet$ Belgrade $\bullet$ Manchester $\bullet$ Tokyo $\bullet$ Cluj $\bullet$ Tianjin MDPI 
Editor

Stefano D'Errico

Department of Pharmacy,

University of Naples Federico II

Italy

\section{Editorial Office}

MDPI

St. Alban-Anlage 66

4052 Basel, Switzerland

This is a reprint of articles from the Special Issue published online in the open access journal Molbank (ISSN 1422-8599) (available at: https:/ /www.mdpi.com/journal/molbank/special_issues/ side_reaction).

For citation purposes, cite each article independently as indicated on the article page online and as indicated below:

LastName, A.A.; LastName, B.B.; LastName, C.C. Article Title. Journal Name Year, Volume Number, Page Range.

ISBN 978-3-0365-0004-1 (Hbk)

ISBN 978-3-0365-0005-8 (PDF)

(C) 2020 by the authors. Articles in this book are Open Access and distributed under the Creative Commons Attribution (CC BY) license, which allows users to download, copy and build upon published articles, as long as the author and publisher are properly credited, which ensures maximum dissemination and a wider impact of our publications.

The book as a whole is distributed by MDPI under the terms and conditions of the Creative Commons license CC BY-NC-ND. 


\section{Contents}

About the Editor $\ldots \ldots \ldots \ldots \ldots \ldots \ldots \ldots \ldots \ldots \ldots \ldots \ldots \ldots \ldots$

Stefano D’Errico

Editorial: Special Issue "Molecules from Side Reactions"

Reprinted from: Molbank 2020, 2020, M1172, doi:10.3390/M1172 . . . . . . . . . . . . . . 1

Nattawut Sawengngen, Alexandra A. Kolodina and Olga V. Serdyuk

(E)-4-(3-Phenylisoxazol-5-yl)but-3-en-2-one

Reprinted from: Molbank 2019, 2019, M1081, doi:10.3390/M1081 _ . . . . . . . . . . . . . 5

Dumitrela Cucu (Diaconu) and Violeta Mangalagiu

Pyridine-Imidazlolium Salts: Oxidatively Cleavage of N-C Bond via Nitration

Reprinted from: Molbank 2019, 2019, M1095, doi:10.3390/M1095 . . . . . . . . . . . . . 11

Michael R. Imrich and Thomas Ziegler

Access to D- and L-Psicose Derivatives via Hydroxy Methylation of Ribono Lactone

Reprinted from: Molbank 2019, 2019, M1096, doi:10.3390/M1096 . . . . . . . . . . . . . 15

Andrea Patrizia Falanga, Maria Marzano, Monica Terracciano and Stefano D’Errico

5'-Chloro-5'-deoxy-2', 3'-O-isopropylidene-6-fluoro nebularine

Reprinted from: Molbank 2019, 2019, M1097, doi:10.3390/M1097 . . . . . . . . . . . . . 23

Hamad H. Al Mamari and Yousuf Al Lawati

$\mathrm{N}$-(2-Hydroxy-1,1-dimethylethyl)-3-methylbenzamide

Reprinted from: Molbank 2020, 2020, M1099, doi:10.3390/M1099 . . . . . . . . . . . . . . . 29

Júlio C. A. V. Soares and Luiza R. S. Dias

$N^{\prime}$-Acetyl-3-methyl-1,6-diphenyl-1H-pyrazolo[3,4-b]pyridine-4-carbohydrazide

Reprinted from: Molbank 2020, 2020, M1104, doi:10.3390/M1104 . . . . . . . . . . . . . 35

Marius Bayer, Cäcilia Maichle-Mössmer and Thomas Ziegler

Unexpected Formation of Oxetanes during the Synthesis of Dodeco-6,7-diuloses

Reprinted from: Molbank 2020, 2020, M1108, doi:10.3390/M1108 . . . . . . . . . . . . . . 41

Eleni Dimitriou and Gavin J. Miller

Synthesis and Isolation of Diastereomeric Anomeric Sulfoxides from a D-Mannuronate

Thioglycoside Building Block

Reprinted from: Molbank 2020, 2020, M1111, doi:10.3390/M1111 . . . . . . . . . . . . . 51

Andrei Solodinin, James Helmkay, Samuel Ollivier and Hongbin Yan

8-Fluoro- $N$-2-isobutyryl-2'-deoxyguanosine: Synthesis and Reactivity

Reprinted from: Molbank 2020, 2020, M1119, doi:10.3390/M1119 . . . . . . . . . . . . 55

Kristin Leyerer, Stefan Koppermann and Christian Ducho

Unexpected Seven-Membered Ring Formation for Muraymycin-Type

Nucleoside-Peptide Antibiotics

Reprinted from: Molbank 2020, 2020, M1122, doi:10.3390/M1122 _ . . . . . . . . . . . . 65

Susanne M. Petrova and Leiv K. Sydnes

Formation of an Isomeric Mixture of Dienynes Instead of a Diallene

Reprinted from: Molbank 2020, 2020, M1133, doi:10.3390/M1133 . . . . . . . . . . . . . . 73 
Jérôme Husson and Laurent Guyard

$4^{\prime}$-(N-(Propan-1,2-dienyl)pyrrol-2-yl)-2,2': 6', 2"'-terpyridine

Reprinted from: Molbank 2020, 2020, M1142, doi:10.3390/M1142 . . . . . . . . . . . . . . . . . . 79

Peter W. R. Corfield and Joseph R. Dayrit

Poly[1,3-Dimethyltetrahydropyrimidin-2(1H)-iminium [tri- $\mu_{2}$-cyanido- $\kappa^{6} \mathrm{C}: \mathrm{N}-$ dicuprate(I)]]

Reprinted from: Molbank 2020, 2020, M1170, doi:10.3390/M1170 . . . . . . . . . . . . . . . . . 85 


\section{About the Editor}

Stefano D'Errico studied Organic Chemistry at the University of Naples Federico II. He finished his doctoral studies in 2009 with a thesis entitled "Synthesis and Structural Characterization of Quadruplex Forming Oligonucleotides and Studies on Solid Phase Synthesis of Nucleoside and Nucleotide Analogues". Between 2009 and 2015, he conducted his research at the Department of Pharmacy of University of Naples Federico II. Since 2016, he has been a Technologist at the same University. In 2017, he obtained qualification as Associate Professor in Organic Chemistry. His current research activities mainly focus on the development of innovative synthetic methodologies for the preparation of novel bioactive modified nucleosides and nucleotides, and on the solid-phase synthesis of oligonucleotides to be exploited in the fields of medicinal and supramolecular chemistry. 



\title{
Editorial \\ Editorial: Special Issue "Molecules from Side Reactions"
}

\author{
Stefano D'Errico \\ Department of Pharmacy, University of Naples Federico II, via D. Montesano, 49, 80131 Naples, Italy; \\ stefano.derrico@unina.it
}

Received: 24 November 2020; Accepted: 27 November 2020; Published: 30 November 2020

Organic synthesis is a powerful tool that allows researchers to express their scientific creativity. Its fundamental role in obtaining drugs and creating new materials is irrefutable evidence. However, a chemical process may often take a side route, generating novel unexplored products. Most chemical reactions produce side products, which are often set aside and even thrown away. If the side product is formed in large amounts or if its presence makes difficult the chromatographic purification procedures, the desire to throw it away is even stronger. Let us suppose that a chemist is in the middle of a total synthesis made up of several synthetic steps and that, during a key step, he or she notes on thin layer chromatography (TLC)the formation of an intense spot with Rf that, in their knowledge, cannot belong to the target compound. At first glance, this side product, generated by a side reaction, could be discouraging and frustrating; however, the isolation and characterization of that product could give the possibility to better investigate the mechanism of reaction. The obtainment of a side product cannot fail to fascinate a chemist that works in the field of synthesis as (i) novel reactions may be discovered and (ii) novel molecular scaffolds may be achieved. The purpose of the Special Issue "Molecules from Side Reactions" was to collect papers reporting on the synthesis and characterization of those products that could be useful building blocks for the whole scientific community. The Special Issue was launched in July 2019 and collected 13 contributions by the end of 2020. The authors contributing to this Special Issue, whom the Guest Editor sincerely thanks, described the science elegantly and rationally; in addition, they characterized the side products according to the rigorous standards of Molbank. The published papers cover the following aspects of the organic chemistry field:

- Synthesis of Heterocycles

- Synthesis of Carbohydrates

- $\quad$ Synthesis of Modified Nucleosides

- C-H Bond Functionalization

- Mechanisms of Reactions

In the first paper, an oxidative ring opening reaction was reported to convert a disubstituted furan ring to isoxazole [1]. This reaction could be useful for the construction of linked isoxazoles and other new complex structures containing an isoxazole subunit. In the second paper, the nitration of pyridine-imidazolium salt was described. It proceeded with the oxidative cleavage of a $\mathrm{N}-\mathrm{C}$ bond between imidazolium ring and methylene group, with the formation of two side products [2]. In the third paper, the authors described the access to the rare $\mathrm{D}$ - and L-psicose derivatives via hydroxy methylation of the ribono lactone [3]. The fourth paper dealt with the synthesis of an intriguing side product obtained during the $5^{\prime}$-ribose fluorination of the nucleoside 6-chloropurine riboside [4]. This reaction occurred during the preparation of a valuable, more lipophilic, analogue of the imidazo-nucleoside AICAR [5]. In the fifth paper, the synthesis of a $N$-(2-hydroxy-1,1-dimethylethyl)-3-methylbenzamide was accomplished. The importance of the compound lies in its potential reactivity as an 
$\mathrm{N}, \mathrm{O}$-bidentate directing group in metal-catalyzed $\mathrm{C}-\mathrm{H}$ bond functionalization reactions [6]. In the sixth paper, an interesting and unexpected obtainment of $N^{\prime}$-acetylhydrazides from hydrolysis of the 3-acetyl-2,3-dihydro-1,3,4-oxadiazole derivatives of 1,6-diphenyl-1H-pyrazolo[3,4-b]pyridine nucleus was presented [7]. In the seventh paper, an unexpected epoxide-oxetane rearrangement was observed during the synthesis of symmetrical dodeco-6,7-diuloses, that are potential candidates for inhibition of glycosidases [8]. In the eighth paper, a novel glycosyl sulfoxide was synthesized from a S-phenyl thioglycoside for the preparation of alginate oligosaccharides [9]. In the ninth paper, the authors discovered that the incorporation of 8-fluoro- $\mathrm{N}$-2-isobutyryl-2'-deoxyguanosine into oligonucleotides through the phosphoramidite chemistry-based solid phase synthesis failed to give the desired products. These results prompted the authors to explore an alternative $N$-protecting group and to modify the solid phase synthetic cycle conditions [10]. In the tenth paper, the authors focused on the synthesis of peptidyl nucleosides as antibacterial agents. During their study to prepare an intermediate to be attached to a solid support, they found an interesting side product with a seven-membered ring [11]. In the eleventh paper, the formation of an isomeric mixture of dienynes, instead of a diallene, was detected during a reduction reaction performed on the 1,1,2,2,7,7,8,8-octaethoxyocta-3,5-diyne [12]. In the twelfth paper, the authors reported on the synthesis of a new pyrrole-substituted terpyridine derivative that possessed an allene moiety. It was obtained as an unexpected sole product during attempts to alkylate the $\mathrm{N}$-atom of pyrrole [13]. In the last paper, the serendipitous formation of the cyclic guanidinium complex poly[1,3-dimethyltetrahydropyrimidin-2(1H)-iminium [tri- $\mu_{2}$-cyanido- $\kappa^{6} \mathrm{C}: \mathrm{N}$-dicuprate(I)]] was found during an $\mathrm{X}$-ray analysis of the crystals obtained after an attempted synthesis of a copper cyanide polymer involving the diamine $N, N^{\prime}$-1,3-dimethyldiaminopropane [14]. All this research confirms the importance of isolating, characterizing and always preserving all the products formed during a reaction. A side product obtained from a side reaction could be as useful an intermediate as a novel pharmaceutical lead. Finally, special thanks go also to all the reviewers, who always helped the Guest Editor to make clear and final decisions, maintaining the high-quality standards of Molbank.

Conflicts of Interest: The author declares no conflict of interest.

\section{References}

1. Sawengngen, N.; Kolodina, A.A.; Serdyuk, O.V. (E)-4-(3-Phenylisoxazol-5-yl)but-3-en-2-one. Molbank 2019, 2019, M1081. [CrossRef]

2. Cucu Diaconu, D.; Mangalagiu, V. Pyridine-imidazlolium salts: Oxidatively cleavage of N-C bond via nitration. Molbank 2019, 2019, M1095. [CrossRef]

3. Imrich, M.R.; Ziegler, T. Access to D-and L-psicose derivatives via hydroxy methylation of Ribono Lactone. Molbank 2019, 2019, M1096. [CrossRef]

4. Falanga, A.P.; Marzano, M.; Terracciano, M.; D'Errico, S. 5'-Chloro-5'-deoxy-2', 3'-O-isopropylidene-6-fluoro nebularine. Molbank 2019, 2019, M1097. [CrossRef]

5. D’Errico, S.; Oliviero, G.; Borbone, N.; Amato, J.; Piccialli, V.; Varra, M.; Mayol, L.; Piccialli, G. Solid-phase synthesis of a new diphosphate 5-aminoimidazole-4-carboxamide riboside (AICAR) derivative and studies toward cyclic AICAR diphosphate ribose. Molecules 2011, 16, 8110-8118. [CrossRef] [PubMed]

6. Al Mamari, H.H.; Al Lawati, Y. N-(2-Hydroxy-1,1-dimethylethyl)-3-methylbenzamide. Molbank 2020, 2020, M1099. [CrossRef]

7. Soares, J.C.A.V.; Dias, L.R.S. N'-Acetyl-3-methyl-1,6-diphenyl-1H-pyrazolo[3,4-b]pyridine-4-carbohydrazide. Molbank 2020, 2020, M1104. [CrossRef]

8. Bayer, M.; Maichle-Mössmer, C.; Ziegler, T. Unexpected formation of oxetanes during the synthesis of dodeco-6,7-diuloses. Molbank 2020, 2020, M1108. [CrossRef]

9. Dimitriou, E.; Miller, G.J. Synthesis and isolation of diastereomeric anomeric sulfoxides from a D-mannuronate thioglycoside building block. Molbank 2020, 2020, M1111. [CrossRef]

10. Solodinin, A.; Helmkay, J.; Ollivier, S.; Yan, H. 8-Fluoro-N-2-isobutyryl-2'-deoxyguanosine: Synthesis and Reactivity. Molbank 2020, 2020, M1119. [CrossRef] 
11. Leyerer, K.; Koppermann, S.; Ducho, C. Unexpected seven-membered ring formation for muraymycin-type nucleoside-peptide antibiotics. Molbank 2020, 2020, M1122. [CrossRef]

12. Petrova, S.M.; Sydnes, L.K. Formation of an isomeric mixture of dienynes instead of a diallene. Molbank 2020, 2020, M1133. [CrossRef]

13. Husson, J.; Guyard, L. 4' -(N-(Propan-1,2-dienyl)pyrrol-2-yl)-2,2' :6' ,2"'-terpyridine. Molbank 2020, 2020, M1142 [CrossRef]

14. Corfield, W.R.; Dayrit, J.R. Poly[1,3-Dimethyltetrahydropyrimidin-2(1H)-iminium [tri- $\mu_{2}$-cyanido- $\kappa^{6} \mathrm{C}: \mathrm{N}-$ dicuprate $\left.(\mathrm{I})\right]$. Molbank 2020, 2020, M1170. [CrossRef]

Publisher's Note: MDPI stays neutral with regard to jurisdictional claims in published maps and institutional affiliations.

(C) 2020 by the author. Licensee MDPI, Basel, Switzerland. This article is an open access article distributed under the terms and conditions of the Creative Commons Attribution (CC BY) license (http://creativecommons.org/licenses/by/4.0/). 



\title{
(E)-4-(3-Phenylisoxazol-5-yl)but-3-en-2-one
}

\author{
Nattawut Sawengngen ${ }^{1}$, Alexandra A. Kolodina ${ }^{2}$ and Olga V. Serdyuk ${ }^{1, *}$ \\ 1 Department of Chemistry and Pharmacy, Institute of Organic Chemistry I, University of \\ Erlangen-Nuremberg, Nikolaus-Fiebiger-Str. 10, 91058 Erlangen, Germany; sawengngen.n@gmail.com \\ 2 Institute of Physical and Organic Chemistry, Southern Federal University, 194/2 Stachki St., \\ Rostov on Don 344090, Russia; akolodina@sfedu.ru \\ * Correspondence: olga@serdyuk.de; Tel.: +49-9131-85-65345
}

Received: 19 August 2019; Accepted: 17 September 2019; Published: 18 September 2019

\begin{abstract}
E)-4-(3-Phenylisoxazol-5-yl)but-3-en-2-one was synthesized via the oxidative ring opening reaction of 2-(5-methylfuran-2-yl)-1-phenylethanone oxime, followed by the iodine mediated isomerization.
\end{abstract}

Keywords: oxazole; furan; RORC reaction; $(E, Z)$-isomerization

\section{Introduction}

The isoxazole ring is a structural motif of numerous bioactive compounds, including several marketed drugs [1]. Substituted isoxazoles are known as promising anticancer [2-5], antifungal [6], antidepressant [7], antioxidant [8], and antituberculous agents [9]. Additionally, some of the isoxazoles demonstrate herbicidal [10] and insecticidal [11] properties.

In 2017, Pinho e Melo et al. described a new synthesis of isoxazoles from tetrahydrofurooxazines via the intermediate formation of oximes (Scheme 1) [12]. Main products of this acid-catalyzed reaction were substituted 4-(isoxazol-5-yl)butan-2-ones 3. On the other hand, minor isoxazolylvinyl ketones (E)-4 are of special interest, due to an active enone fragment, which can be utilized for the construction of linked isoxazoles [13] and other new complex structures containing an isoxazole subunit [14].

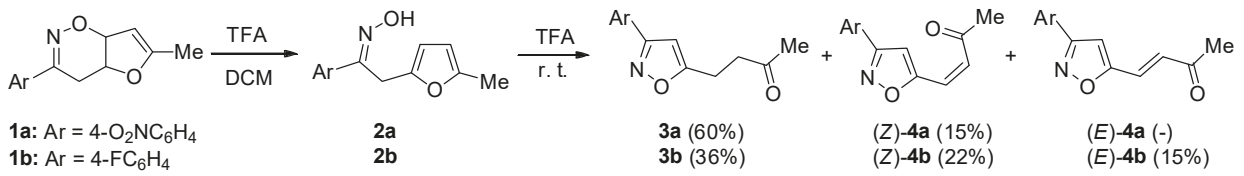

Scheme 1. Acid-catalyzed formation of isoxazolylvinyl ketones as minor products.

Herein, we describe an easy approach to (E)-4-(3-phenylisoxazol-5-yl)but-3-en-2-one 4c, and its characterization by $1 \mathrm{D}$ and 2D NMR spectroscopy.

\section{Results and Discussion}

Oxime $\mathbf{2 c}$ was synthesized via the reaction of furfuryl ketone 5 with hydroxylamine hydrochloride, and sodium acetate in ethanol. The subsequent furan ring opening-isoxazole ring closure reaction of $2 \mathrm{c}$ under oxidative conditions [15,16] provided the target 4-(3-phenylisoxazol-5-yl)but-3-en-2-one 4c in high yield as a mixture of (E,Z)-isomers (Scheme 2). 


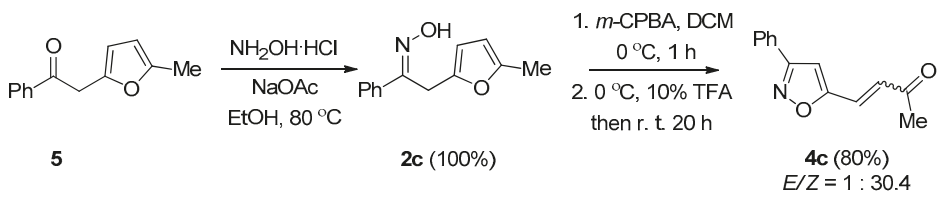

Scheme 2. Synthesis of compound 4c.

Isoxazole $(E)-4 \mathbf{c}$ was obtained in a pure form through iodine-mediated isomerization [17] and fully characterized (Scheme 3).

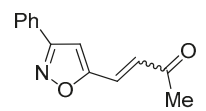

$(E, Z)-4 c$

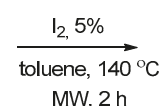

MW, 2 h

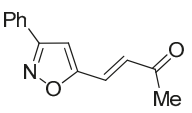

(E)-4c (100\%)

Scheme 3. Isomerization $(E, Z)-4 \mathbf{c} \rightarrow(E)-4 \mathbf{c}$.

The structure of compound $4 \mathrm{c}$ was confirmed by $1 \mathrm{H}$ and $2 \mathrm{D}$ nuclear magnetic resonance spectroscopy: $\quad{ }^{1} \mathrm{H}-{ }^{1} \mathrm{H}$ correlation spectroscopy (COSY), ${ }^{1} \mathrm{H}_{-}{ }^{13} \mathrm{C}$ heteronuclear single-quantum correlation spectroscopy (HSQC), and ${ }^{1} \mathrm{H}_{-}{ }^{13} \mathrm{C}$ heteronuclear multiple-bond correlation spectroscopy (HMBC) (Figures 1-3). In the ${ }^{1} \mathrm{H}$ NMR spectrum of $(E)-4 \mathrm{c}$, signals of the vinyl protons $\alpha-\mathrm{H}$ and $\beta-\mathrm{H}$ are observed at $\delta \mathrm{H}=6.95$ and $7.40 \mathrm{ppm}$, respectively, and have a coupling constant of $16.2 \mathrm{~Hz}$, which indicates a (E)-configuration (Figure S1). In the ${ }^{1} \mathrm{H}_{-}{ }^{13} \mathrm{C}$ HMBC spectrum, there are cross-peaks between the $\alpha-\mathrm{H}$ proton and $\mathrm{C}$-atom of the methyl group ( $\delta \mathrm{C} 28.5 \mathrm{ppm}$ ) and isoxazole $\mathrm{C}(5)$ atom $(\delta \mathrm{C} 166.3 \mathrm{ppm})$. The $\beta-\mathrm{H}$ proton correlates with carbonyl carbon atom at $\delta \mathrm{C} 197.0 \mathrm{ppm}$ and isoxazole $\mathrm{C}(4)$ atom at $\delta \mathrm{C}$ $104.5 \mathrm{ppm}$. Cross-peaks between the proton $\mathrm{H}(4)$ at $\delta \mathrm{H} 6.80 \mathrm{ppm}$ and $\beta-\mathrm{C}$ atom of the acetyl vinyl fragment at $\delta \mathrm{C} 125.4 \mathrm{ppm}$, and between protons of the methyl group at $\delta \mathrm{H} 2.41 \mathrm{ppm}$ and $\alpha-\mathrm{C}$ atom of the acetyl vinyl fragment at $\delta \mathrm{C} 130.8 \mathrm{ppm}$ are observed as well. All key cross-peaks are presented in Table 1.

Table 1. Cross-peaks in heteronuclear single-quantum correlation and heteronuclear multiple-bond correlation spectra of compound $(E)-4 c$.

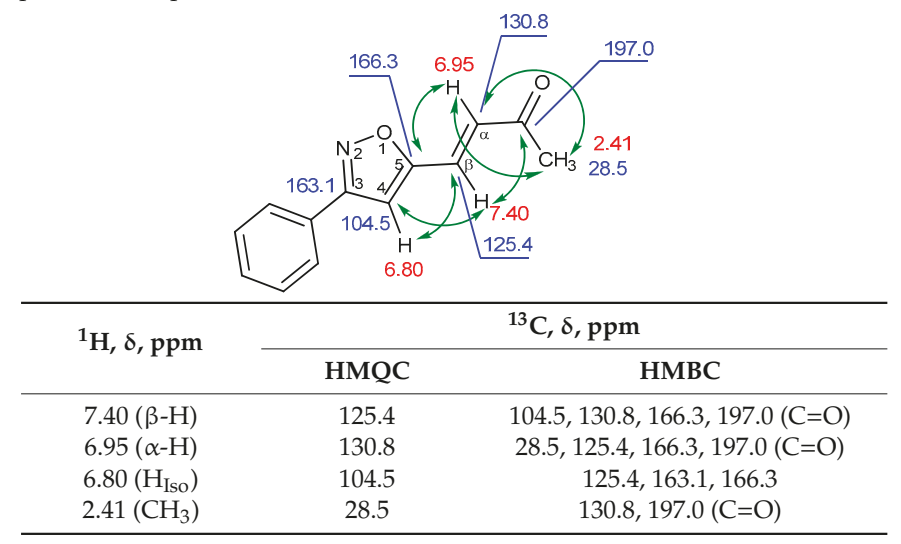

In summary, we have suggested an effective route to (E)-4-(3-phenylisoxazol-5-yl)but-3-en-2-one employing oxidative RORC reaction of furfuryl ketone oxime. The exploration of the reaction scope is underway in our laboratory. 


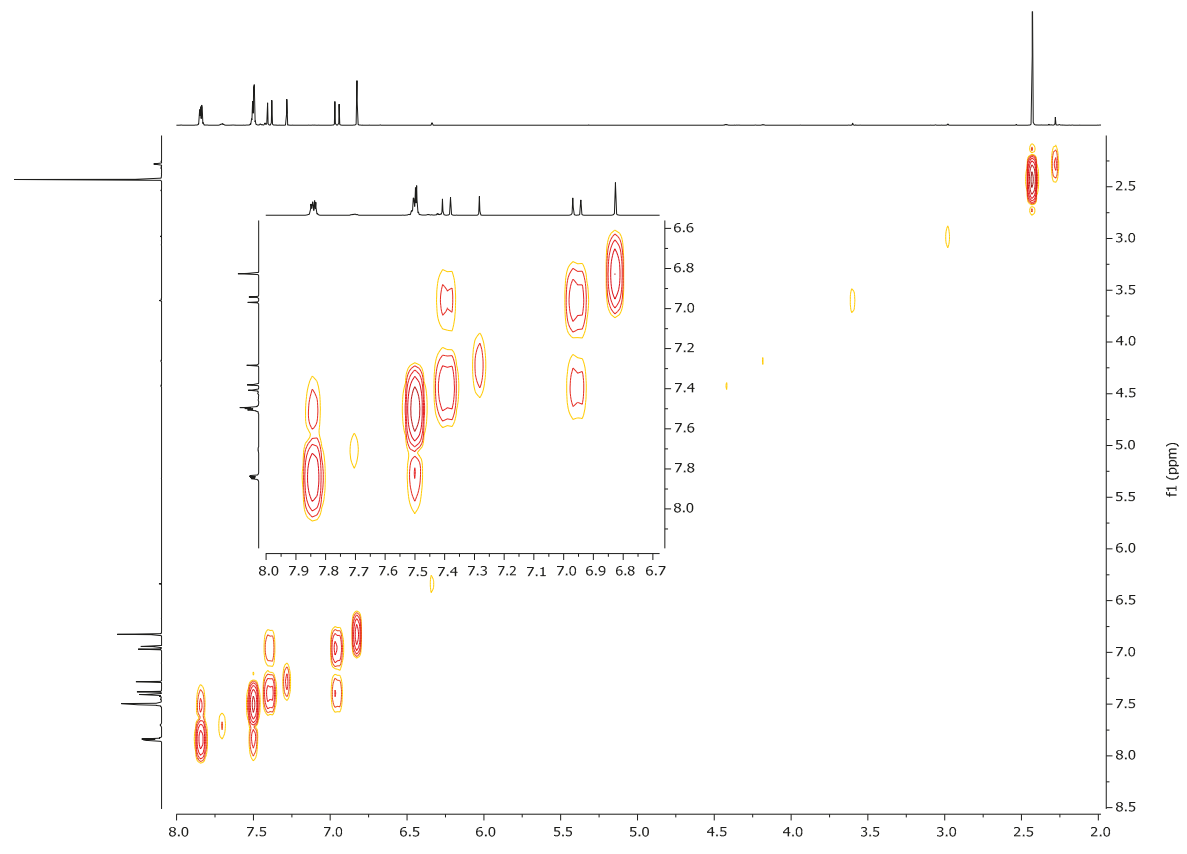

Figure 1. Data of ${ }^{1} \mathrm{H}-{ }^{1} \mathrm{H}$ correlation spectroscopy for compound $(E)-4 \mathrm{c}\left(\mathrm{CDCl}_{3}\right)$.

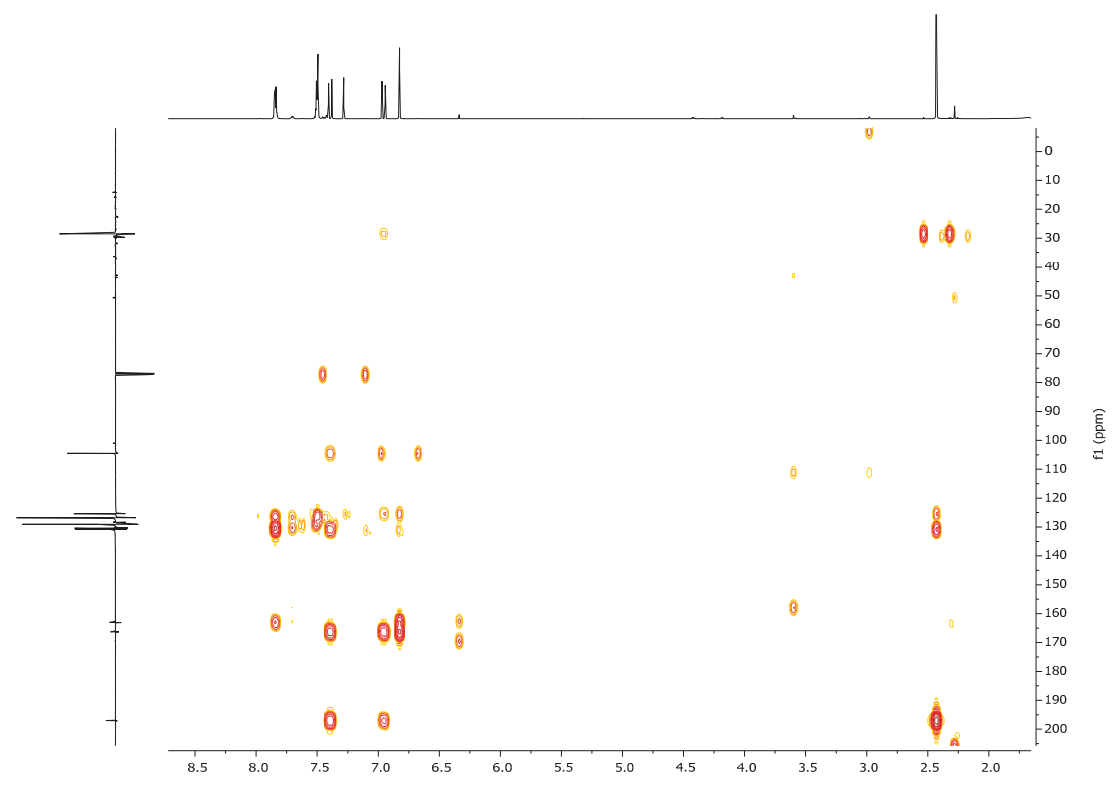

Figure 2. Data of ${ }^{1} \mathrm{H}_{-}{ }^{13} \mathrm{C}$ heteronuclear multiple-bond correlation spectroscopy for compound (E)-4c $\left(\mathrm{CDCl}_{3}\right)$. 


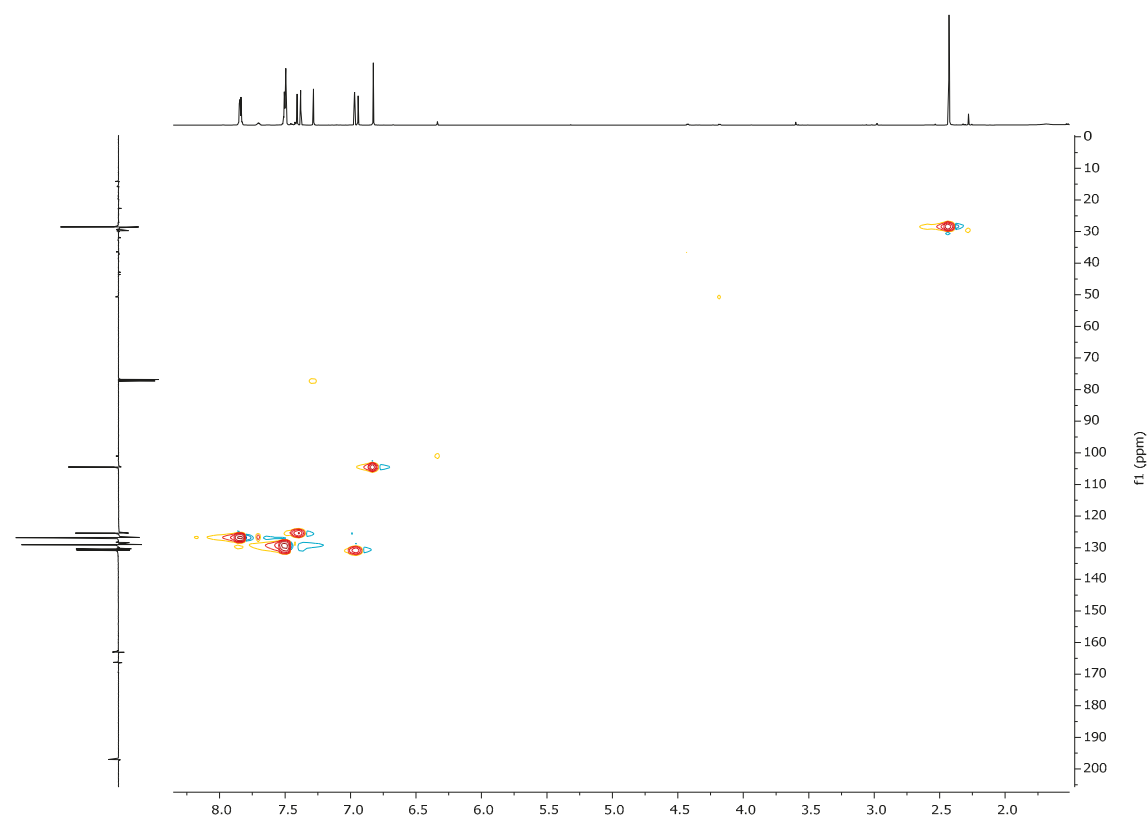

Figure 3. Data of ${ }^{1} \mathrm{H}_{-}{ }^{13} \mathrm{C}$ heteronuclear single-quantum correlation spectroscopy for compound (E)-4c $\left(\mathrm{CDCl}_{3}\right)$.

\section{Materials and Methods}

All commercial products and solvents were used without further purification (Fisher Scientific, Loughborough, UK). All reactions were run under the air unless noted otherwise.

The reactions under microwave irradiation were conducted in Microwave Synthesis Reactor «Biotage ${ }^{\circledR}$ Robot Eight» (Biotage AB, Uppsala, Sweden) using sealed microwave reaction vessels. TLC analyses were performed on Merck 60 F254 aluminum plates in combination with UV detection (254 nm). Flash chromatography was performed on silica gel 200-300 mesh (Merck, Darmstadt, Germany) using mixture EtOAc/i-hexane as eluents. Melting points were determined on a Mel-Temp II Laboratory Devices apparatus (Triad Scientific Manasquan, Manasquan, NJ, USA); the values are uncorrected. NMR spectra were recorded on a Bruker AV-600 $\left({ }^{1} \mathrm{H}\right.$ NMR at $600 \mathrm{MHz}$ and ${ }^{13} \mathrm{C}$ NMR at $151 \mathrm{MHz}$,) and Bruker AV-400 $\left({ }^{1} \mathrm{H}\right.$ NMR at $400 \mathrm{MHz}$ and ${ }^{13} \mathrm{C}$ NMR at $101 \mathrm{MHz}$ ) spectrometers (Bruker $\mathrm{GmbH}$, Mannheim, Germany). Proton chemical shifts ( $\delta$ ) are reported in parts per million (ppm) relative to tetramethylsilane (TMS), with the solvent resonance employed as the internal standard $\left(\mathrm{CDCl}_{3} \delta=7.26 \mathrm{ppm}\right)$. Data are reported as follows: chemical shift, multiplicity ( $\mathrm{s}=$ singlet, $\mathrm{d}=$ doublet, $\mathrm{t}=$ triplet, $\mathrm{q}=$ quartet $\mathrm{m}=$ multiplet, $\mathrm{dd}=$ doublet of doublets, $\mathrm{dt}=$ doublet of triplets), coupling constants $(J)$ and integration. Coupling constants $(J)$ are reported in Hertz $(\mathrm{Hz})$. Carbon chemical shifts are reported in ppm from tetramethylsilane (TMS), with the solvent resonance as the internal standard $\left(\mathrm{CDCl}_{3} \delta=77.16 \mathrm{ppm}\right)$.

IR spectra were measured on PerkinElmer Spectrum BX spectrophotometer $(\mathrm{NaCl}$ plates, PerkinElmer LAS GmbH, Rodgau, Germany). HRMS-ESI spectra were recorded at The Mass Spectroscopy Laboratory, Chair of Organic Chemistry, Friedrich-Alexander University of Erlangen-Nuremberg.

Starting furfuryl ketone 5 was obtained according to the published procedure [18].

2-(5-Methylfuran-2-yl)-1-phenylethan-1-one oxime (2c) 
Hydroxylamine hydrochloride $(2 \mathrm{mmol})$ and anhydrous $\mathrm{NaOAc}(4 \mathrm{mmol})$ were added to a solution of furfuryl ketone $5(2 \mathrm{mmol})$ in ethanol $(5 \mathrm{~mL})$, and the mixture was stirred for $24 \mathrm{~h}$ at $80{ }^{\circ} \mathrm{C}$ (TLC and LC-MS control). Then, the reaction mixture was poured into $\mathrm{H}_{2} \mathrm{O}(100 \mathrm{~mL})$ and extracted with EtOAc $(4 \times 25 \mathrm{~mL})$. The combined organic phases were washed with brine, dried over anhydrous $\mathrm{Na}_{2} \mathrm{SO}_{4}$, filtered, and evaporated under reduced pressure. The resulting crude product was purified by flash chromatography using EtOAc/i-Hex as eluents.

Yield $0.61 \mathrm{~g}(100 \%)$. White solid. M.p. $90-92{ }^{\circ} \mathrm{C} .{ }^{1} \mathrm{H}$ NMR $\left(600 \mathrm{MHz}, \mathrm{CDCl}_{3}\right): \delta=7.69-7.67(\mathrm{~m}$, 2H), 7.37-7.36 (m, 3H), $5.92(\mathrm{~d}, J=3.0 \mathrm{~Hz}, 1 \mathrm{H}), 5.83(\mathrm{~m}, 1 \mathrm{H}), 4.13(\mathrm{~s}, 2 \mathrm{H}), 2.24(\mathrm{~s}, 3 \mathrm{H}) \mathrm{ppm} .{ }^{13} \mathrm{C} \mathrm{NMR}$ $\left(101 \mathrm{MHz} \mathrm{CDCl}_{3}\right): \delta=155.2,150.9,147.9,135.3,129.4,128.5,126.4,107.5,106.3,25.5,13.6$ ppm. IR (NaCl): 3241, 2922, 1568, 1495, 1461, 1321, 1168, 1016, $960 \mathrm{~cm}^{-1}$. HRMS (ESI): $\mathrm{m} / z$ calcd. for $\mathrm{C}_{13} \mathrm{H}_{13} \mathrm{NO}_{2}$ $[\mathrm{M}-\mathrm{H}]^{+}:$214.0868; found: 214.0862 .

(E,Z)-4-(3-Phenylisoxazol-5-yl)but-3-en-2-one ((E,Z)-4c)

$m$-CPBA $(77 \% \mathrm{w} / \mathrm{w}, 0.135 \mathrm{~g}, 0.6 \mathrm{mmol})$ was added to a solution of oxime $2 \mathrm{c}(0.5 \mathrm{mmol})$ in DCM $(2 \mathrm{~mL})$ at $0{ }^{\circ} \mathrm{C}$. The reaction mixture was stirred at the same temperature for $1 \mathrm{~h}$. Then TFA $(0.038 \mathrm{~mL}$, $0.05 \mathrm{mmol}$ ) was added. The reaction mixture was allowed to reach room temperature and stirred for $20 \mathrm{~h}$. Once the reaction was complete, the mixture was washed with $\mathrm{Na}_{2} \mathrm{~S}_{2} \mathrm{O}_{3}$ solution three times, and then with brine. DCM was dried over anhydrous $\mathrm{Na}_{2} \mathrm{SO}_{4}$, filtered, and evaporated under reduced pressure to give a pure $(E, Z)-4$.

(Z)-4-(3-Phenylisoxazol-5-yl)but-3-en-2-one ((Z)-4c)

In a mixture with $(E)$-isomer. ${ }^{1} \mathrm{H} \mathrm{NMR}\left(600 \mathrm{MHz}, \mathrm{CDCl}_{3}\right): \delta=7.87-7.86(\mathrm{~m}, 2 \mathrm{H}), 7.69(\mathrm{~s}, 1 \mathrm{H})$, $7.48-7.44(\mathrm{~m}, 3 \mathrm{H}), 6.74(\mathrm{~d}, J=12.8 \mathrm{~Hz}, 1 \mathrm{H}), 6.43(\mathrm{~d}, J=12.8 \mathrm{~Hz}, 1 \mathrm{H}), 2.37(\mathrm{~s}, 3 \mathrm{H}) \mathrm{ppm} .{ }^{13} \mathrm{C}$ NMR $\left(101 \mathrm{MHz} \mathrm{CDCl}_{3}\right): \delta=197.8,166.0,163.2,130.8,130.4,130.1,128.9,126.8,123.5,106.0,31.5 \mathrm{ppm}$.

Isomerization $(E, Z)-\mathbf{4} \rightarrow(E)-\mathbf{4}$

Microwave reaction vessel was charged with $(E, Z)-4 \mathrm{c}(0.2 \mathrm{mmol}), \mathrm{I}_{2}(0.0034 \mathrm{~g}, 0.013 \mathrm{mmol})$, and toluene $(5 \mathrm{~mL})$. The reaction mixture was stirred at $140{ }^{\circ} \mathrm{C}$ in a microwave reactor for $2 \mathrm{~h}$. After completion of the reaction, toluene and iodine were removed under reduced pressure to afford pure $(E)-3 a$.

(E)-4-(3-Phenylisoxazol-5-yl)but-3-en-2-one) (E)-4c)

Yield $0.034 \mathrm{~g}(80 \%)$. White solid. M.p. $130-132{ }^{\circ} \mathrm{C} .{ }^{1} \mathrm{H}$ NMR $\left(600 \mathrm{MHz}, \mathrm{CDCl}_{3}\right): \delta=7.83-7.81$ (m, 2H), 7.49-7.47 (m, 3H), 7.40 (d, J = 16.2 Hz, 1H), 6.95 (d, J = 16.2 Hz, 1H), 6.80 (s, 1H), $2.41(\mathrm{~s}, 3 \mathrm{H})$ ppm. ${ }^{13} \mathrm{C} \mathrm{NMR}\left(151 \mathrm{MHz}, \mathrm{CDCl}_{3}\right): \delta=197.0,166.3,163.1,130.8,130.4,129.1,128.4,126.8,125.4,104.5$, 28.5 ppm. IR (NaCl): $1664(\mathrm{C}=\mathrm{O}), 1560,1439,1268,983,952,769 \mathrm{~cm}^{-1}$. HRMS (ESI): $m / z$ calcd. for $\mathrm{C}_{13} \mathrm{H}_{11} \mathrm{NO}_{2}[\mathrm{M}+\mathrm{H}]^{+}$: 214.0868; found: 214.0861 .

Supplementary Materials: The following are available online, Figure S1: ${ }^{1} \mathrm{H}$ NMR spectrum of compound 2c, Figure S2: ${ }^{13} \mathrm{C}$ NMR spectrum of compound 2c, Figure S3: ${ }^{1} \mathrm{H}$ NMR spectrum of compound $(E)-4 \mathrm{c}$, Figure S4: ${ }^{13} \mathrm{C}$ NMR spectrum of compound (E)-4c, Figure S5: ${ }^{1} \mathrm{H}$ NMR spectrum of compound $(Z)-4 c$, Figure S6: ${ }^{13} \mathrm{C}$ NMR spectrum of the compound (Z)-4c.

Author Contributions: N.S.—synthesis, A.A.K.-NMR data analysis, writing the manuscript, O.V.S. conceptualization, supervision, data analysis, writing the manuscript, funding acquisition. All authors read and approved the final manuscript.

Funding: This research was funded by the program "Promotion of Equal Opportunities for Women in Research and Teaching" (FFL) Bayern, Germany.

Acknowledgments: We thank Peter Gmeiner, Department of Chemistry and Pharmacy, University of Erlangen-Nuremberg, for his kind support.

Conflicts of Interest: The authors declare no conflict of interest. 


\section{References}

1. Sysak, A.; Obmińska-Mrukowicz, B. Isoxazole ring as a useful scaffold in a search for new therapeutic agents. Eur. J. Med. Chem. 2017, 137, 292-309. [CrossRef] [PubMed]

2. Rajanarendar, E.; Nagi Reddy, M.; Rama Krishna, S.; Govardhan Reddy, K.; Reddy, Y.N.; Rajam, M.V. Design, synthesis, in vitro antimicrobial and anticancer activity of novel methylenebis-isoxazolo [4,5- $b$ ]azepines derivatives. Eur. J. Med. Chem. 2012, 50, 344-349. [CrossRef] [PubMed]

3. Güiza, F.M.; Duarte, Y.B.; Mendez-Sanchez, S.C.; Bohórquez, A.R.R. Synthesis and in vitro evaluation of substituted tetrahydroquinoline-isoxazole hybrids as anticancer agents. Med. Chem. Res. 2019, 28, 1182-1196. [CrossRef]

4. Wang, H.; Ma, Y.; Lin, Y.; Liu, J.; Chen, R.; Xu, B.; Liang, Y. An Isoxazole derivative SHU00238 suppresses colorectal cancer growth through miRNAs regulation. Molecules 2019, 24, 2335. [CrossRef] [PubMed]

5. Xue, X.; Zhang, Y.; Wang, C.; Zhang, M.; Xiang, Q.; Wang, J.; Wang, A.; Li, C.; Zhang, C.; Zou, L.; et al. Benzoxazinone-containing 3,5-dimethylisoxazole derivatives as BET bromodomain inhibitors for treatment of castration-resistant prostate cancer. Eur. J. Med. Chem. 2018, 152, 542-559. [CrossRef] [PubMed]

6. Santos, M.M.M.; Faria, N.; Iley, J.; Coles, S.J.; Hursthouse, M.B.; Martins, M.L.; Moreira, R. Reaction of naphthoquinones with substituted nitromethanes. Facile synthesis and antifungal activity of naphtho[2,3-d]isoxazole-4,9-diones. Bioorg. Med. Chem. Lett. 2010, 20, 193-195. [CrossRef] [PubMed]

7. Yu, L.F.; Tückmantel, W.; Eaton, J.B.; Caldarone, B.; Fedolak, A.; Hanania, T.; Brunner, D.; Lukas, R.J.; Kozikowski, A.P. Identification of novel $\alpha 4 \beta 2$-nicotinic acetylcholine receptor (nAChR) agonists based on an isoxazole ether scaffold that demonstrate antidepressant-like activity. J. Med. Chem. 2012, 55, 812-823. [CrossRef] [PubMed]

8. Padmaja, A.; Rajasekhar, C.; Muralikrishna, A.; Padmavathi, V. Synthesis and antioxidant activity of oxazolyl/thiazolylsulfonylmethyl pyrazoles and isoxazoles. Eur. J. Med. Chem. 2011, 46, 5034-5038. [CrossRef] [PubMed]

9. Moraski, G.C.; Chang, M.; Villegas-Estrada, A.; Franzblau, S.G.; Möllmann, U.; Miller, M.J. Structure-activity relationship of new anti-tuberculosis agents derived from oxazoline and oxazole benzyl esters. Eur. J. Med. Chem. 2010, 45, 1703-1716. [CrossRef] [PubMed]

10. Zhou, Y.; Chen, Y.; Miao, W.; Qu, J. Synthesis, structures, and herbicidal activity of isoxazole derivatives. J. Heterocycl. Chem. 2010, 47, 1310-1316. [CrossRef]

11. Upadhyay, A.; Gopal, M.; Srivastava, C.; Pandey, N.D. Isoxazole derivatives as a potential insecticide for managing Callosobruchus chinensis. J. Pestic. Sci. 2010, 35, 464-469. [CrossRef]

12. Alves, A.J.S.; Lopes, S.M.M.; Henriques, M.S.C.; Paixão, J.A.; Pinho e Melo, T.M.V.D. Hetero-Diels-Alder and ring-opening reactions of furans applied to the synthesis of functionalized heterocycles. Eur. J. Org. Chem. 2017, 27, 4011-4025. [CrossRef]

13. Voskienè, A.; Mickevičius, V. Cyclization of chalcones to isoxazole and pyrazole derivatives. Chem. Heterocycl. Compd. 2009, 45, 1485-1488.

14. For application of some related systems through the functionalization of enone fragment, see: Trushkov, I.V.; Uchuskin, M.U.; Abaev, V.T.; Serdyuk, O.V. Indolylvinyl ketones: Building blocks for the synthesis of natural products and bioactive compounds. Synthesis 2019, 51, 787-815.

15. Merino, P.; Tejero, T.; Delso, J.I.; Matute, R. Furan oxidations in organic synthesis: Recent advances and applications. Curr. Org. Chem. 2007, 11, 1076-1091. [CrossRef]

16. Makarov, A.S.; Uchuskin, I.V.; Trushkov, I.V. Furan oxidation reactions in the total synthesis of natural products. Synthesis 2018, 50, 3059-3086.

17. Dugave, C.; Demange, L. Cis-Trans isomerization of organic molecules and biomolecules: implications and applications. Chem. Rev. 2003, 103, 2475-2532. [CrossRef] [PubMed]

18. Sawengngen, N.; Chalikidi, P.N.; Araby, S.; Hampel, F.; Gmeiner, P.; Serdyuk, O.V. Synthesis of pyrazolylvinyl ketones from furan derivatives. Org. Biomol. Chem. 2019, 17, 4850-4855. [CrossRef] [PubMed]

(C) 2019 by the authors. Licensee MDPI, Basel, Switzerland. This article is an open access article distributed under the terms and conditions of the Creative Commons Attribution (CC BY) license (http://creativecommons.org/licenses/by/4.0/). 


\title{
Pyridine-Imidazlolium Salts: Oxidatively Cleavage of N-C Bond via Nitration
}

\author{
Dumitrela Cucu (Diaconu) ${ }^{1}$ and Violeta Mangalagiu ${ }^{2, *}$ \\ 1 Faculty of Chemistry, Alexandru Ioan Cuza University of Iasi, 11 Carol, 700506 Iasi, Romania; \\ cucu.dumitrela@yahoo.ro \\ 2 Institute of Interdisciplinary Research-CERNESIM Center, Alexandru Ioan Cuza University of Iasi, \\ 11 Carol I, 700506 Iasi, Romania \\ * Correspondence: violeta.mangalagiu@uaic.ro
}

Received: 8 November 2019; Accepted: 21 November 2019; Published: 23 November 2019

\begin{abstract}
Azaheterocycles derivatives with pyridine-imidazole skeleton are compounds of great value for medicinal chemistry. We report herein the nitration of $1,1^{\prime}$-(pyridine-2,6diylbis(methylene))bis\{3-[2-(4-nitrophenyl)-2-oxoethyl]-1H-imidazol-3-ium\} bromide using a typical mixture of nitric and sulphuric acid. The nitration occur with the oxidative cleavage of $\mathrm{N}-\mathrm{C}$ bond between imidazolium ring and methylene group.
\end{abstract}

Keywords: nitration; azaheterocycles; $\mathrm{N}-\mathrm{C}$ bond cleavage; pyridine-imidazolium

\section{Introduction}

In the past decades five and six member ring azaheterocycles compounds, especially imidazole and (di)azine, became invaluable scaffolds in drug designing because of their large variety of biological activities, such as anticancer, antimicrobial (antibacterial, antifungal, antitubercular), antimalarial, anti-inflammatory, antidepressant, analgesic, antihypertensive etc. [1-7].

Taking into consideration our expertise in the area of obtaining new biologically active compounds with antimicrobial activity [8-14] using cycloimmonium ylides chemistry [15-21], we decided to study the reactions of pyridine-imidazolium salts with nitric acid.

\section{Results and Discussion}

In this respect, we perform the nitration of 1,1'-[pyridine-2,6-diylbis(methylene)]bis\{3-[2-(4nitrophenyl)-2-oxoethyl]-1 $\mathrm{H}$-imidazol-3-ium $\}$ bromide 1, using a typical mixture of nitric and sulphuric acid, Figure 1.

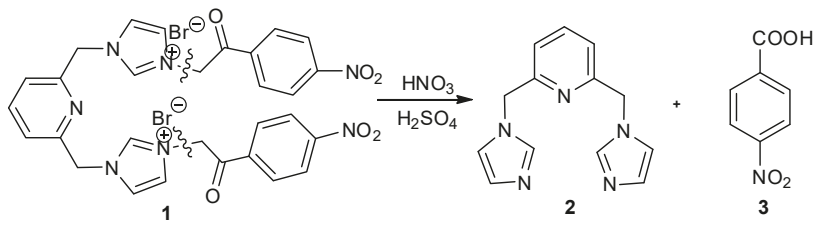

Figure 1. The nitration of 1,1'-[pyridine-2,6-diylbis(methylene)]bis\{3-[2-(4-nitrophenyl)-2-oxoethyl]- $1 H$ imidazol-3-ium\} bromide.

Our expectation was to have a nitration in the 3-position of pyridine ring or in the 4-position of the imidazole moiety. Instead of this an unexpected oxidative cleavage $\mathrm{N}-\mathrm{C}$ bond between imidazolium ring and methylene group took place, with the formation of 2,6-bis[(1H-imidazol-1-yl)methyl]pyridine 
2 and 4-nitrobenzoic acid 3. The structures of compounds were proven by spectroscopic analysis: ${ }^{1} \mathrm{H}-\mathrm{NMR},{ }^{13} \mathrm{C}-\mathrm{NMR}$, and two-dimensional experiments 2D- COSY, 2D-HMQC, 2D-HMBC.

In conclusions, nitration of 1,1'-[pyridine-2,6-diylbis(methylene)]bis\{3-[2-(4-nitrophenyl)-2oxoethyl]-1H-imidazol-3-ium\} bromide occur with the oxidative cleavage of $\mathrm{N}-\mathrm{C}$ bond between imidazolium ring and methylene group, with the formation of two side products 2,6-bis[( $1 \mathrm{H}$ imidazol-1-yl)methyl]pyridine 2 and 4-nitrobenzoic acid 3.

\section{Materials and Methods}

\subsection{Instrumentation}

All the reagents and solvents were purchased from commercial sources (Sigma Aldrich and Merck, Darmstadt, Germany) and used without further purification. Melting points were recorded on an Electrothermal MEL-TEMP (Barnstead International, Dubuque, IA, USA) apparatus in open capillary tubes and are uncorrected. Analytical thin-layer chromatography was performed with commercial silica gel plates 60 F254 (Merck) and visualized with UV light. The NMR spectra were recorded on a (Bruker, Vienna, Austria) Advance III $500 \mathrm{MHz}$ spectrometer operating at $500 \mathrm{MHz}$ for ${ }^{1} \mathrm{H}$ and 125 $\mathrm{MHz}$ for ${ }^{13} \mathrm{C}$. Chemical shifts were reported in delta $(\delta)$ units, part per million (ppm) and coupling constants $(J)$ in $\mathrm{Hz}$.

2,6-Bis[(1H-imidazol-1-yl)methyl]pyridine 2, was initially synthetized by Garrison and Co [22]; in the supporting information of the paper all the data concerning the compound can be found for comparison.

4-Nitrobenzoic acid 3, is a commercially available compound and relevant data can be found in the Sigma-Aldrich catalog [23].

\subsection{Nitration of Pyridine-Imidazolium Salts}

Concentrated nitric acid ( $\mathrm{HNO}_{3} 65 \%$, p.a.) (4.89 mmol, 9.78 equiv., $0.22 \mathrm{~mL}$ ) was added dropwise over the undissolved quaternary salt $1(0.5 \mathrm{mmol}, 1$ equiv., $0.36 \mathrm{~g})$ at $0{ }^{\circ} \mathrm{C}$ (ice bath) under vigorous stirring, until the entire precipitate has been dissolved $(10 \mathrm{~min})$ completely. Concentrated sulfuric acid $\left(\mathrm{H}_{2} \mathrm{SO}_{4} 98 \%\right)(3.825 \mathrm{mmol}, 7.65$ equiv., $0.21 \mathrm{~mL})$ was added dropwise, at $0{ }^{\circ} \mathrm{C}$ (ice bath), over the reaction mixture. The resulting solution was stirred at room temperature for $30 \mathrm{~min}$, and after that heated at $130{ }^{\circ} \mathrm{C}$ for $2 \mathrm{~h}$. The nitrogen oxides released were bubbled into a water bath. The reaction was processed by neutralization with a saturated $\mathrm{NaHCO}_{3}$ solution $(0.95 \mathrm{~mL})$. The formed precipitate was collected by filtration, washed with distilled $\mathrm{H}_{2} \mathrm{O}(5-7 \mathrm{~mL})$, and dried in vacuum, obtaining 2,6-bis[( $1 H$-imidazol-1-yl)methyl]pyridine 2 as a white powder.

From the aqueous phase the extraction was performed with ethyl acetate $(3 \times 20 \mathrm{~mL})$, the phase was separated and the organic layer was dried over sodium sulphate. After filtration, the solution was left overnight, resulting in the formation of a yellow acicular precipitate, 4-nitrobenzoic acid.

2,6-Bis[(1H-imidazol-1-yl)methyl]pyridine (2). White powder, m.p. $106-107^{\circ} \mathrm{C}$. Yield $32 \% .{ }^{1} \mathrm{H}-\mathrm{NMR}$ (500 MHz, DMSO) (ppm): $7.78\left(\mathrm{t}, 1 \mathrm{H}, 3 \mathrm{~J}=8.0 \mathrm{~Hz}, \mathrm{H}_{4}\right), 7.74\left(\mathrm{~s}, 2 \mathrm{H}, 2 \mathrm{H}_{2^{\prime}}\right), 7.19\left(\mathrm{as}, 2 \mathrm{H}, 2 \mathrm{H}_{5^{\prime}}\right), 7.03(\mathrm{~d}$, $\left.2 \mathrm{H}, 3 \mathrm{~J}=8.0 \mathrm{~Hz}, 2 \mathrm{H}_{3}\right), 6.92\left(\mathrm{as}, 2 \mathrm{H}, 2 \mathrm{H}_{4^{\prime}}\right), 5.28\left(\mathrm{~s}, 4 \mathrm{H}, 2\left(-\mathrm{CH}_{2}-\right) .{ }^{13} \mathrm{C}-\mathrm{NMR}(125 \mathrm{MHz}, \mathrm{DMSO})(\mathrm{ppm})\right.$ : $156.7\left(2 \mathrm{C}_{2}\right), 138.5\left(\mathrm{C}_{4}\right), 137.7\left(2 \mathrm{C}_{2^{\prime}}\right), 128.6\left(2 \mathrm{C}_{4^{\prime}}\right), 120.4\left(2 \mathrm{C}_{3}\right), 119.8\left(2 \mathrm{C}_{5^{\prime}}\right), 51.13\left(2\left(-\mathrm{CH}_{2}-\right)\right)$.

4-Nitrobenzoic Acid (3). Yellow acicular crystals, m.p. $237-238^{\circ} \mathrm{C}$. Yield 41\%. ${ }^{1} \mathrm{H}-\mathrm{NMR}(400 \mathrm{MHz}$, DMSO) (ppm): 13.67 (brs, $1 \mathrm{H},-\mathrm{COOH}), 8.30\left(\mathrm{~d}, 2 \mathrm{H}, 3 \mathrm{~J}=7.6 \mathrm{~Hz}, 2 \mathrm{H}_{3}\right), 8.15\left(\mathrm{~d}, 2 \mathrm{H}, 3 \mathrm{~J}=7.6 \mathrm{~Hz}, 2 \mathrm{H}_{2}\right)$. ${ }^{13} \mathrm{C}-\mathrm{NMR}(100 \mathrm{MHz}, \mathrm{DMSO})(\mathrm{ppm}): 165.8(-\mathrm{COOH}), 150.0\left(\mathrm{C}_{4}\right), 136.3\left(\mathrm{C}_{1}\right), 130.7\left(2 \mathrm{C}_{3}\right), 123.7\left(2 \mathrm{C}_{2}\right)$.

Supplementary Materials: ${ }^{1} \mathrm{H}$ - and ${ }^{13} \mathrm{C}$-NMR spectra for compounds $\mathbf{2}$ and $\mathbf{3}$ are available online.

Author Contributions: Conception and writing were performed by V.M. Experimental work and structure elucidation were performed by D.C. and V.M. All authors reviewed and approved the final version. 
Funding: This research was funded by Romanian Ministry of Research and Innovation, Program 1-Development of the national R \& D system, Subprogram 1.2-Institutional performance-RDI excellence financing projects, Grant No. 34PFE/19.10.2018.

Acknowledgments: Authors are thankful to Romanian Ministry of Research and Innovation, Program 1-Development of the national R \& D system, Subprogram 1.2-Institutional performance-RDI excellence financing projects, Grant No. 34PFE/19.10.2018, for financial support and the POSCCE-O 2.2.1, SMIS-CSNR 13984-901, No. 257/28.09.2010 Project, CERNESIM, for NMR experiments.

Conflicts of Interest: The authors declare no conflict of interest.

\section{References}

1. Popovici, L.; Amarandi, R.M.; Mangalagiu, I.I.; Mangalagiu, V.; Danac, R. Synthesis, molecular modelling and anticancer evaluation of new pyrrolo[1,2-b]pyridazine and pyrrolo[2,1-a]phthalazine derivatives. J. Enzym. Inh. Med. Chem. 2019, 34, 230-243. [CrossRef] [PubMed]

2. Lungu, C.N.; Bratanovici, B.I.; Grigore, M.M.; Antoci, V.; Mangalagiu, I.I. Hybrid imidazole-pyridine derivatives: An approach to novel anticancer DNA intercalators. Curr. Med. Chem. 2018, in press. [CrossRef] [PubMed]

3. Olaru, A.M.; Vasilache, V.; Danac, R.; Mangalagiu, I.I. Antimycobacterial activity of nitrogen heterocycles derivatives: 7-(pyridine-4-yl)-indolizine derivatives. Part VII. J. Enz. Inhib. Med. Chem. 2017, 32, 1291-1298. [CrossRef] [PubMed]

4. Mantu, D.; Antoci, V.; Moldoveanu, C.; Zbancioc, G.; Mangalagiu, I.I. Hybrid imidazole (benzimidazole)/pyridine (quinoline) derivatives and evaluation of their anticancer and antimycobacterial activity. J. Enz. Inhib. Med. Chem. 2016, 31, 96-103. [CrossRef] [PubMed]

5. Mantu, D.; Maftei, D.; Iurea, D.; Ursu, C.; Bejan, V. Synthesis, structure, and in vitro anticancer activity of new polycyclic 1,2-diazines. Med. Chem. Res. 2014, 23, 2909-2915. [CrossRef]

6. Luca, M.C.; Tura, V.; Mangalagiu, I.I. Considerations concerning design and mechanism of action of a new class of dual DNA intercalators. Med. Hyp. 2010, 75, 627-629. [CrossRef] [PubMed]

7. Gaba, M.; Mohan, C. Development of drugs based on imidazole and benzimidazole bioactive heterocycles: Recent advances and future directions. Med. Chem. Res. 2016, 25, 173-210. [CrossRef]

8. Al Matarneh, C.M.; Shova, S.; Mangalagiu, I.I.; Danac, R. Synthesis, structure, antimycobacterial and anticancer evaluation of new pyrrolo-phenanthroline derivatives. J. Enz. Inhib. Med. Chem. 2016, 31, 470-480. [CrossRef]

9. Danac, R.; Al Matarneh, C.M.; Shova, S.; Daniloaia, T.; Balan, M.; Mangalagiu, I.I. New indolizines with phenanthroline skeleton: Synthesis, structure, antimycobacterial and anticancer evaluation. Bioorg. Med. Chem. 2015, 23, 2318-2327. [CrossRef]

10. Danac, R.; Managalagiu, I.I. Antimycobacterial activity of nitrogen heterocycles derivatives: Bipyridine derivatives. Part III. Eur. J. Med. Chem. 2014, 74, 664-670. [CrossRef]

11. Tucaliuc, R.; Cotea, V.; Niculaua, M.; Tuchilus, C.; Mantu, D.; Mangalagiu, I.I. New Pyridazine-Fluorine Derivatives: Synthesis, Chemistry and Biological Activity. Part II. Eur. J. Med. Chem. 2013, 67, 367-372. [CrossRef] [PubMed]

12. Mantu, D.; Antoci, V.; Mangalagiu, I.I. Design, synthesis and antituberculosis activity of some new pyridazine derivatives: Bis-pyridazine. Part IV. Infect. Disord. Drug. Targets 2013, 13, 344-351. [CrossRef] [PubMed]

13. Mantu, D.; Luca, M.C.; Moldoveanu, C.; Zbancioc, G.; Mangalagiu, I.I. Synthesis and antituberculosis activity of some new pyridazine derivatives. Part II. Eur. J. Med. Chem. 2010, 45, 5164-5168. [CrossRef] [PubMed]

14. Butnariu, R.; Mangalagiu, I.I. New pyridazine derivatives: Synthesis, chemistry and biological activity. Bioorg. Med. Chem. 2009, 17, 2823-2829. [CrossRef]

15. Cucu, D.; Mangalagiu, V.; Amariucai-Mantu, D.; Antoci, V.; Mangalagiu, I.I. Imidazolium ylides: Cycloaddition versus hydrolysis. Studia UBB Chemia 2019, LXIV(3), 59-66. [CrossRef]

16. Zbancioc, G.; Mangalagiu, I.I.; Moldoveanu, C. Ultrasound assisted synthesis of imidazolium salts: An efficient way to ionic liquids. Ultrason. Sonochem. 2015, 23, 376-383. [CrossRef]

17. Zbancioc, G.; Zbancioc, A.M.; Mangalagiu, I.I. Ultrasound and microwave assisted synthesis of dihydroxyacetophenone derivatives with or without 1,2-diazine skeleton. Ultrason. Sonochem. 2014, 21, 802-811. [CrossRef] 
18. Zbancioc, G.; Zbancioc, A.M.; Mantu, D.; Miron, A.; Tanase, C.; Mangalagiu, I.I. Ultrasounds assisted synthesis of highly functionalized acetophenone. Rev. Roum. Chim. 2010, 55, 983-987.

19. Zbancioc, G.; Bejan, V.; Risca, M.; Moldoveanu, C.; Mangalagiu, I.I. Microwave assisted reactions of new azaheterocyles compounds. Molecules 2009, 14, 403-411. [CrossRef]

20. Mantu, D.; Moldoveanu, C.; Nicolescu, A.; Deleanu, C.; Mangalagiu, I.I. A facile synthesis of pyridazinone derivatives under ultrasonic irradiation. Ultrason. Sonochem. 2009, 16, 452-454. [CrossRef]

21. Bejan, V.; Moldoveanu, C.; Mangalagiu, I.I. Ultrasounds assisted reactions of steroid analogous of anticipated biological activities. Ultrason. Sonochem. 2009, 16, 312-315. [CrossRef] [PubMed]

22. Garrison, J.C.; Simons, R.S.; Talley, J.M.; Wesdemiotis, C.; Tessier, C.A.; Youngs, W.J. Synthesis and Structural Characterization of an Imidazolium-Linked Cyclophane and the Silver Complex of an N-Heterocyclic Carbene-Linked Cyclophane. Organometallics 2001, 20, 1276-1278. [CrossRef]

23. Available online: https://www.sigmaaldrich.com/catalog/product/sial/72910?lang=en\&region=RO\&gclid= EAIaIQobChMI2Lbo_oP55QIVE-R3Ch1CQwsMEAAYASAAEgIiTfD_BwE (accessed on 16 November 2019).

(C) 2019 by the authors. Licensee MDPI, Basel, Switzerland. This article is an open access article distributed under the terms and conditions of the Creative Commons Attribution (CC BY) license (http://creativecommons.org/licenses/by/4.0/). 
Communication

\title{
Access to D- and L-Psicose Derivatives via Hydroxy Methylation of Ribono Lactone
}

\author{
Michael R. Imrich and Thomas Ziegler * \\ Institute of Organic Chemistry, University of Tuebingen, Auf der Morgenstelle 18, 72076 Tuebingen, Germany; \\ michael.imrich@uni-tuebingen.de \\ * Correspondence: thomas.ziegler@uni-tuebingen.de; Tel.: +49-(0)7071-29-78763; Fax: +49-(0)7071-29-5244
}

Received: 18 November 2019; Accepted: 4 December 2019; Published: 10 December 2019

\begin{abstract}
Tri-O-benzyl- and 2,3,5-tri-O-methyl-D-ribono- $\gamma$-lactone were converted with (methoxyethoxymethoxy)methyl and benzyloxy tributylstannane into the corresponding protected D-psicoses as mixtures of anomers in $31 \%-72 \%$ yield. Treatment of 2,3,5-tri-O-methyl-L-ribono- $\gamma$-lactone with benzyloxy tributylstannane afforded the corresponding L-psicose derivative as an anomeric mixture in $72 \%$ yield. Both methylated psicoses were further converted into 1,2-O-isopropylidene-3,4,6-tri-O-methyl-D- and L-psicofuranosides, the respective $\alpha$ and $\beta$-anomers of which could be separated and characterized.
\end{abstract}

Keywords: ribose; psicose; ketose; rare sugar; hydroxy methylation

\section{Introduction}

Only a few ketoses occur in nature in significant amounts. D-Fructose is the only ketose that occurs in large quantities in nature and can be isolated from plant material [1]. Other ketoses like psicose (Figure 1) are rare carbohydrates which cannot be isolated in considerable amounts from natural sources. They can be synthesized either by isomerization of the corresponding aldoses in low yields or by multi-step syntheses involving different protection and deprotection steps or by enzymatic methods [2-8] resulting in a high price for these ketoses. As part of an ongoing research project about the synthesis of carbohydrate derived catalysts for asymmetric syntheses [9-12] we required considerable amounts of $\mathrm{D}$ - and L-psicofuranose derivatives 3 . Due to the high price of both enantiomers of psicose [13] we developed a specific synthetic route for the preparation of D- and L-psicose derivatives 3 , starting from $\mathrm{D}$ - and L-ribose (2). We chose ribose as the starting material because both enantiomers of this sugar are commercially available at decent costs [13] and the stereocenters possess the same configuration as psicose.<smiles>O=C(CO)C(O)C(O)C(O)CO</smiles>

D-1

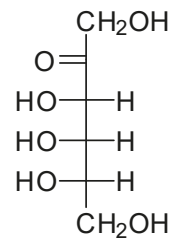

L-1<smiles>CC(CO)C(O)C(O)C=O</smiles>

D-2<smiles>O=CC(O)C(O)CO</smiles>

L-2<smiles>COC(C(C)O)C(OCCO)C(=O)CO</smiles>

D-3

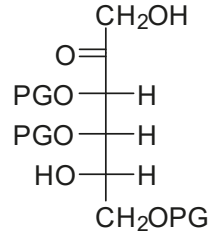

L-3

Figure 1. Fischer projection of D- and L-psicose (1), D- and L-ribose (2) and D- and L-psicose derivatives 3. PG-protective group. 


\section{Results and Discussion}

We first established a synthetic route starting with the cheap D-enantiomer of ribose and applied our findings later to the more expensive L-enantiomer. Since ribose is a pentose and psicose a hexose, the carbohydrate chain of the ribose had to be elongated by one carbon atom. Our strategy for accomplishing this was to first convert ribose to the corresponding lactone 6 and then elongate its carbon chain at C-1 via addition of the organometallic reagent 5 (Scheme 1). The latter could be obtained from tributylstannyl methanol 4 by transmetallation with butyl lithium and had already been used for the elongation of other carbohydrate derivatives [14-17].

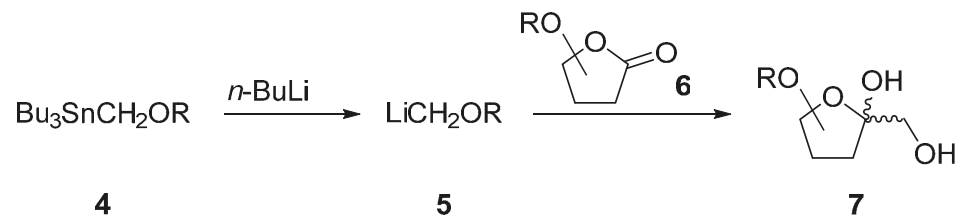

Scheme 1. Planned elongation of the carbohydrate chain in order to derive hexose from a pentose.

At first we attempted to react known tri-O-benzyl ribono lactone (8) [18] with unprotected 4 (4a, $\mathrm{R}=\mathrm{H}$ ) [19] since this approach would have led directly to the target molecules without the need of any additional protecting group manipulations. Unfortunately, treatment of $\mathbf{D}-8$ with 4 a only resulted in decomposition of the starting materials. Next, we decided to use a suitably protected stannyl reagent 4 since such reagents had previously been used successfully for the elongation of other aldose derivatives. As a protecting group we chose the methoxyethoxmethyl group (MEM) due to its orthogonality to benzyl protecting groups and its facile removal [20]. In fact, treatment of lactone $\mathbf{D}-8$ with MEM-protected $\mathbf{4 b}$ afforded the corresponding elongated sugar $\mathbf{D}-\mathbf{9}$, however in rather poor yield (Scheme 2).
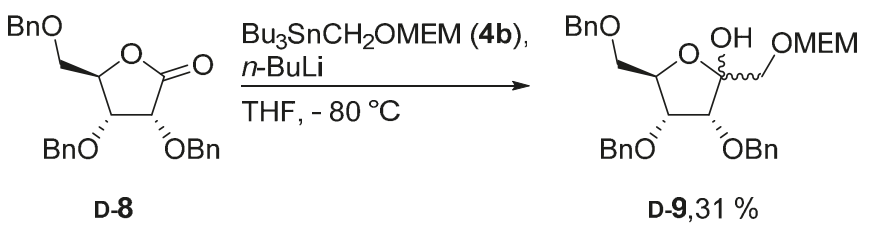

Scheme 2. Hydroxy methylation of D-8 with methoxyethoxmethyl group (MEM)-protected organotin compound $4 \mathrm{~b}$.

It is known that stannyl reagents of the type 4 may rearrange upon transmetallation, with butyl lithium. Most likely this was the reason for the observed low yield. Such rearrangements may depend on the nature of the protecting group in 4. [19] Therefore, we decided to use a supposedly more stable benzyl group instead of the MEM protective group for reagent 4 . In order to keep orthogonality between the protective groups at the ribono lactone and the stannyl reagent we also changed the substituents at the lactone accordingly. Here, we chose methyl groups as they can be introduced easily and are stable to broad range of reaction conditions. Thus known ribose derivative D-10 [21] was first oxidized to D-11 in excellent yield using iodine as the oxidant (Scheme 3). Addition of $\mathbf{D}-\mathbf{1 1}$ to a solution of the benzylated organotin reagent $\mathbf{4} \mathbf{c}$ and $n$-BuLi finally provided $\mathbf{D}-\mathbf{1 2}$ in good yield as an inseparable mixture of anomers. 
<smiles>COCC1O[C@H](O)[C@H](OC)[C@H]1OC</smiles>

D-10

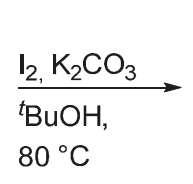

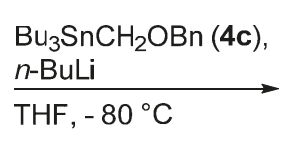<smiles>COCC1O[C@](O)(Cc2ccccc2)[C@H](OC)[C@H]1OC</smiles>

D-12,72\%

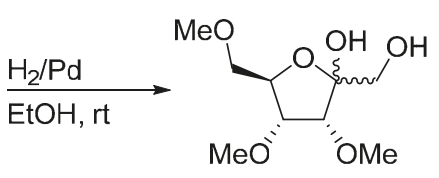

D-13,92\%
D-11, $92 \%$<smiles>COC[C@H]1OC(=O)[C@H](OC)[C@@H]1OC</smiles>
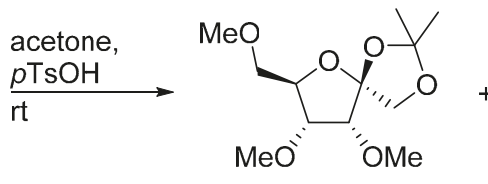

$\mathrm{D}-14,70 \%$<smiles>COCC1O[C@@]2(COC(C)(C)O2)[C@H](OC)[C@@H]1OC</smiles>

D-15,16\%

Scheme 3. Synthesis of methylated D-psicose derivatives.

Next, the benzyl group at position 1 of psicose derivative $\mathbf{D}-\mathbf{1 2}$ was reductively removed in very high yield using palladium on charcoal as the catalyst. Deprotected compound D-13 again emerges as a mixture of inseparable anomers. In order to obtain an anomerically pure substance we further modified $\mathbf{D}-\mathbf{1 3}$ by converting it into the corresponding isopropylidene derivatives $\mathbf{D}-\mathbf{1 4}$ and $\mathbf{D}-\mathbf{1 5}$ both of which could be isolated in pure form. The configuration at the anomeric center of $\mathbf{D}-\mathbf{1 4}$ and $\mathbf{D}-\mathbf{1 5}$ was verified by NMR spectroscopy. The NOESY spectrum of $\mathbf{D}-14$ shows a NOE between H-1 and the methyl groups at position 3 and 4 whereas the $\mathbf{D}-\mathbf{1 5}$ has a NOE between $\mathrm{H}-1$ and $\mathrm{H}-3$.

With a working synthetic sequence for the D-enantiomers in hand, we applied it to the L-enantiomer $\mathbf{L - 1 0}$ as well (Scheme 4). L-10 was prepared as described in the literature for the preparation of D-10. [21] As was expected, the synthetic route worked smoothly with yields nearly identical yields to those obtained for the D-enantiomers in all steps of the reaction sequence.<smiles>COC[C@H]1O[C@H](O)[C@@H](OC)[C@H]1OC</smiles>

L-10<smiles>COC[C@H]1OC(=O)[C@H](OC)[C@@H]1OC</smiles>

L-11, $90 \%$

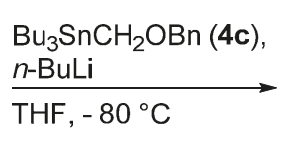<smiles>COC[C@H]1O[C@](O)(COCc2ccccc2)C(OC)[C@@H]1OC</smiles>

$\mathrm{L}-12,69 \%$

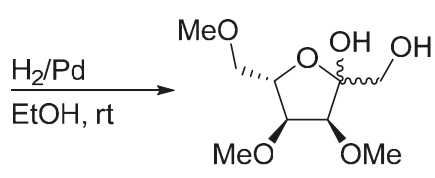

L-13,93\%
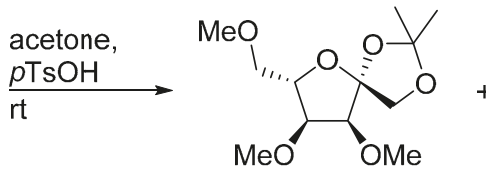

L-14,71\%<smiles>COC[C@H]1OC2(COC(C)(C)O2)[C@H](OC)C1OC</smiles>

L-15, $17 \%$

Scheme 4. Synthesis of methylated L-psicose derivatives. 


\section{Materials and Methods}

\subsection{General Remarks}

Reactions in dry solvents were carried out under an atmosphere of nitrogen. Dry THF was distilled from sodium/benzophenone, dry $\mathrm{CH}_{2} \mathrm{Cl}_{2}$ was distilled from $\mathrm{P}_{4} \mathrm{O}_{10}$, dry acetone was prepared from HPLC grade acetone by the addition of molecular sieves (4 $\AA$ ). Tert-butanol and ethanol were HPLC grade and used without further purification. Solvents used for column chromatography were techniqual grade and distilled prior to their use. Petroleum ether (PE) refers to the fraction boiling at 60-90 ${ }^{\circ} \mathrm{C}$. Silica gel “60 M" from Machery-Nagel was used for column chromatography. For reaction monitoring, TLC plates "Polygram Sil G/U 254 " from Machery-Nagel were used. Optical rotations were measured with a Perkin Elmer "Polarimeter 341". NMR spectra were measured at a Bruker "Avance III HD 400" or a Bruker "Avance HD 300 NanoBay" and are calibrated to the solvent signal. For peak assignment additional spectra (DEPT, COSY, HMBC, HSQC) were recorded. The atoms are numbered in accordance with the carbohydrate nomenclature. High resolution mass spectra were measured at a Bruker "maXis 4G". Elemental analysis was performed using a HEKAtech "Euro $3000 \mathrm{CHN}$ ".

\subsection{Synthesis of Compounds}

[(Methoxy-ethoxy-methoxy)-methyl]tributylstannane (4b): $\quad$ To a solution of tributylstannyl-methanol (4a) $(911 \mathrm{mg}, 2.83 \mathrm{mmol})$ [22] in dry $\mathrm{CH}_{2} \mathrm{Cl}_{2}$ (10 mL) DIPEA (0.72 mL, $4.25 \mathrm{mmol})$ and $\mathrm{MEM}-\mathrm{Cl}(0.49 \mathrm{~mL}, 4.25 \mathrm{mmol})$ were added and the reaction mixture was stirred at room temperature for $16 \mathrm{~h}$. Then, again $\mathrm{MEM}-\mathrm{Cl}(0.16 \mathrm{~mL}, 1.41 \mathrm{mmol})$ was added and the reaction mixture was stirred for additional $5 \mathrm{~h}$. The reaction was quenched by the addition of $\mathrm{MeOH}$ and afterwards water was added. The aqueous phase was extracted with $\mathrm{CH}_{2} \mathrm{Cl}_{2}(3 \times 10 \mathrm{~mL})$. The combined organic layers were dried $\left(\mathrm{Na}_{2} \mathrm{SO}_{4}\right)$ and the solvent was evaporated in vacuo. Column chromatography $\left(\mathrm{PE}+2 \% \mathrm{Et}_{3} \mathrm{~N} \rightarrow \mathrm{PE} / \mathrm{EtOAc}, 20 / 1+2 \% \mathrm{Et}_{3} \mathrm{~N}\right)$ provided $4 \mathrm{~b}(985 \mathrm{mg}, 85 \%)$ as colorless oil. $\mathrm{R}_{\mathrm{f}}=0.50$ $\left(\mathrm{PE} / \mathrm{EtOAc}, 10 / 1+2 \% \mathrm{Et}_{3} \mathrm{~N}\right) ;{ }^{1} \mathrm{H}-\mathrm{NMR}\left(400 \mathrm{MHz}, \mathrm{CDCl}_{3}\right) \delta=4.61\left(\mathrm{~s}, 2 \mathrm{H}, \mathrm{SnCH}_{2} \mathrm{O}\right), 3.76(\mathrm{~s}, 2 \mathrm{H}$, $\left.\mathrm{OCH}_{2} \mathrm{O}\right), 3.62-3.68\left(\mathrm{~m}, 2 \mathrm{H}, \mathrm{OCH}_{2} \mathrm{CH}_{2} \mathrm{O}\right), 3.53-3.61\left(\mathrm{~m}, 2 \mathrm{H}, \mathrm{OCH}_{2} \mathrm{CH}_{2} \mathrm{O}\right), 3.33-3.45\left(\mathrm{~m}, 3 \mathrm{H}, \mathrm{OCH}_{3}\right)$, 1.46-1.56 (m, 6H, $\left.\mathrm{C}_{4} \mathrm{H}_{9}\right), 1.26-1.35\left(\mathrm{~m}, 6 \mathrm{H}, \mathrm{C}_{4} \mathrm{H}_{9}\right), 0.78-0.99\left(\mathrm{~m}, 15 \mathrm{H}, \mathrm{C}_{4} \mathrm{H}_{9}\right) ;{ }^{13} \mathrm{C}-\mathrm{NMR}(101 \mathrm{MHz}$, $\left.\mathrm{CDCl}_{3}\right) \delta=98.6\left(\mathrm{SnCH}_{2} \mathrm{O}\right), 71.8\left(\mathrm{OCH}_{2} \mathrm{CH}_{2} \mathrm{O}\right), 66.5\left(\mathrm{OCH}_{2} \mathrm{CH}_{2} \mathrm{O}\right), 59.0\left(\mathrm{OCH}_{3}\right), 57.7\left(\mathrm{OCH}_{2} \mathrm{O}\right)$, $29.1\left(\mathrm{CH}_{2} \mathrm{C}_{3} \mathrm{H}_{7}\right), 27.3\left(\mathrm{CH}_{2} \mathrm{C}_{3} \mathrm{H}_{7}\right), 13.7\left(\mathrm{CH}_{3} \mathrm{C}_{3} \mathrm{H}_{6}\right), 8.8\left(\mathrm{CH}_{2} \mathrm{C}_{3} \mathrm{H}_{7}\right) ; \mathrm{HRMS}(\mathrm{ESI}-\mathrm{TOF}) \mathrm{m} / z$ [M + Na] ${ }^{+}$: calcd for $\mathrm{C}_{17} \mathrm{H}_{38} \mathrm{O}_{3} \mathrm{SnNa}$ : 433.17351, found: 433.17360; Anal calcd for $\mathrm{C}_{17} \mathrm{H}_{38} \mathrm{O}_{3} \mathrm{Sn}$ : C 49.9, $\mathrm{H}$ 9.36, found: C 49.76, H 9.38 .

3,4,6-Tri-O-benzyl-1-O-(methoxyethoxymethyl)-D-psicose (D-9): To a solution of $\mathbf{4 b}$ (239 $\mathrm{mg}$, $0.58 \mathrm{mmol})$ in dry THF (2 mL) $n$-BuLi (348 $\mu \mathrm{l}, 0.56 \mathrm{mmol} ; 1.6 \mathrm{~m}$ in hexanes) and lactone $\mathbf{D}-8$ (116 mg, $0.28 \mathrm{mmol}$; dissolved in $2 \mathrm{~mL}$ dry THF) were subsequently added at $-80{ }^{\circ} \mathrm{C}$. The reaction mixture was stirred at $-80^{\circ} \mathrm{C}$ for $40 \mathrm{~min}$ and afterwards the reaction was quenched by the addition of water $(5 \mathrm{~mL})$. The mixture was extracted with EtOAc $(3 \times 20 \mathrm{~mL})$ and the combined organic layers were dried $\left(\mathrm{Na}_{2} \mathrm{SO}_{4}\right)$. After evaporation of the solvent, the residue was purified by column chromatography $(\mathrm{PE} /$ EtOAc, $2 / 1 \rightarrow 1 / 1)$, which provided $\mathbf{D}-\mathbf{9}(47 \mathrm{mg}, 31 \%)$ as a colorless oil. $[\alpha]_{D}^{20}=-15.6^{\circ}(\mathrm{c}=1.0$, $\left.\mathrm{CHCl}_{3}\right) ; \mathrm{R}_{\mathrm{f}}=0.25(\mathrm{PE} / \mathrm{EtOAc}, 2 / 1) ;{ }^{1} \mathrm{H}-\mathrm{NMR}\left(400 \mathrm{MHz}, \mathrm{CDCl}_{3}\right) \delta=7.11-7.36(\mathrm{~m}, 15 \mathrm{H}, \mathrm{H}-\mathrm{Ar}), 5.60-5.77$ $(\mathrm{m}, 1 \mathrm{H}, \mathrm{OH}), 4.82-4.86\left(\mathrm{~m}, 1 \mathrm{H}, \mathrm{CH}_{2} \mathrm{Ph}\right), 4.66-4.69\left(\mathrm{~m}, 1 \mathrm{H}, \mathrm{CH}_{2} \mathrm{Ph}\right), 4.58-4.62(\mathrm{~m}, 1 \mathrm{H}, \mathrm{H}-1 \mathrm{a}), 4.54-4.58$ (m, 1H, H-1b), 4.43-4.52 (m, 3H, CH $\mathrm{CH}_{2} \mathrm{Ph}$, 4.35-4.42 (m, 1H, $\left.\mathrm{CH}_{2} \mathrm{Ph}\right), 4.21-4.24$ (m, 1H, H-5), 3.95-4.04 (m, 1H, H-6a), 3.64-3.75 (m, 2H, H-3, MEM), 3.44-3.63 (m, 4H, H-6b, MEM), 3.35-3.42 (m, 3H, H-4, MEM), $3.26\left(\mathrm{~s}, 3 \mathrm{H}, \mathrm{CH}_{3}\right) ;{ }^{13} \mathrm{C}-\mathrm{NMR}\left(101 \mathrm{MHz}, \mathrm{CDCl}_{3}\right) \delta=137.8,137.6,137.5,128.5,128.4,128.4,128.1$, 127.9, 127.9, 127.8, 127.4 (C-Ar), 97.5 (C-2), 95.9 (C-1), 75.4 (C-5), $75.1\left(\mathrm{CH}_{2} \mathrm{Ph}\right), 74.7$ (C-3 or C-4), 73.3 (C-3 or C-4), 71.6 (MEM), 71.4, $71.2\left(\mathrm{CH}_{2} \mathrm{Ph}\right), 69.1,66.9$ (MEM), $58.9\left(\mathrm{CH}_{3}\right), 57.5$ (C-6); HRMS (ESI-TOF) $m / z[\mathrm{M}+\mathrm{Na}]^{+}$: calcd for $\mathrm{C}_{31} \mathrm{H}_{38} \mathrm{O}_{8} \mathrm{Na}: 561.24589$, found: 561.24618 ; Anal calcd for $\mathrm{C}_{31} \mathrm{H}_{38} \mathrm{O}_{8}$ : C 69.13, H 7.11, found: C 68.82, H 7.19.

2,3,5-Tri-O-methyl-D-ribono-1,4-lactone (D-11): A mixture of D-10 (3.83 g, 19.9 mmol), I 2 (10.1 g, $39.8 \mathrm{mmol})$ and $\mathrm{K}_{2} \mathrm{CO}_{3}(5.51 \mathrm{~g}, 39.8 \mathrm{mmol})$ in tert-butanol $(100 \mathrm{~mL})$ was heated to $80{ }^{\circ} \mathrm{C}$ for $90 \mathrm{~min}$. 
The reaction mixture was cooled to room temperature and water $(10 \mathrm{~mL})$ and solid $\mathrm{Na}_{2} \mathrm{~S}_{2} \mathrm{O}_{4}$ were added to quench the excess of iodine. The mixture was filtered and the solvent was evaporated in vacuo. Column chromatography (PE/EtOAc, 2/1 $\rightarrow$ 1/1) provided D-11 (3.50 g, 92\%) as light yellow oil. $[\alpha]_{D}^{20}=+52.3^{\circ}\left(\mathrm{c}=1.0, \mathrm{CHCl}_{3}\right) ; \mathrm{R}_{\mathrm{f}}=0.59(\mathrm{EtOAc}) ;{ }^{1} \mathrm{H}-\mathrm{NMR}\left(300 \mathrm{MHz}, \mathrm{CDCl}_{3}\right) \delta=4.47-4.56(\mathrm{~m}, 1 \mathrm{H}$, $\mathrm{H}-4), 4.25(\mathrm{~d}, J=5.6 \mathrm{~Hz}, 1 \mathrm{H}, \mathrm{H}-2), 4.05(\mathrm{dd}, J=5.6,1.7 \mathrm{~Hz}, 1 \mathrm{H}, \mathrm{H}-3), 3.64\left(\mathrm{~s}, 3 \mathrm{H}, \mathrm{CH}_{3}\right), 3.62(\mathrm{t}, J=2.7 \mathrm{~Hz}$, $2 \mathrm{H}, \mathrm{H}-5), 3.48\left(\mathrm{~s}, 3 \mathrm{H}, \mathrm{CH}_{3}\right), 3.31-3.39\left(\mathrm{~m}, 3 \mathrm{H}, \mathrm{CH}_{3}\right) ;{ }^{13} \mathrm{C}-\mathrm{NMR}\left(75 \mathrm{MHz}, \mathrm{CDCl}_{3}\right) \delta=173.3(\mathrm{C}-1), 80.8$ (C-4), 77.5 (C-3), 76.4 (C-2), 71.6 (C-5), 59.5, 59.2, 58.0 $\left(\mathrm{CH}_{3}\right)$; HRMS (ESI-TOF) $\mathrm{m} / \mathrm{z}[\mathrm{M}+\mathrm{Na}]^{+}$: calcd for $\mathrm{C}_{8} \mathrm{H}_{14} \mathrm{O}_{5} \mathrm{Na}$ : 213.07334, found: 213.07374; Anal calcd for $\mathrm{C}_{8} \mathrm{H}_{14} \mathrm{O}_{5}$ : C 50.52, H 7.42, found: C 50.12, $\mathrm{H} 7.32$.

2,3,5-Tri-O-methyl-L-ribono-1,4-lactone (L-11): Prepared with the same protocol described for D-11, from L-10 (3.50 g, $18.2 \mathrm{mmol}), \mathrm{I}_{2}(9.24 \mathrm{~g}, 36.4 \mathrm{mmol})$ and $\mathrm{K}_{2} \mathrm{CO}_{3}(5.03 \mathrm{~g}, 36.4 \mathrm{mmol})$. Colorless oil, $(3.12 \mathrm{~g}, 90 \%)$ yield after column chromatography. $[\alpha]_{D}^{20}=-51.1^{\circ}\left(\mathrm{c}=1.0, \mathrm{CHCl}_{3}\right) ; \mathrm{R}_{\mathrm{f}}$ and NMR data was identical to D-11; HRMS (ESI-TOF) $m / z[\mathrm{M}+\mathrm{Na}]^{+}$: calcd for $\mathrm{C}_{8} \mathrm{H}_{14} \mathrm{O}_{5} \mathrm{Na}$ : 213.07334, found: 213.07350; Anal calcd for $\mathrm{C}_{8} \mathrm{H}_{14} \mathrm{O}_{5}$ : C 50.52, H 7.42, found: C 50.88, H 7.71.

3,4,6-Tri-O-methyl-1-O-benzyl-D-psicose (D-12): To a solution of 4c (6.36 g, $15.5 \mathrm{mmol})$ [23] in dry THF (25 mL) n-BuLi (11.6 mL, $18.5 \mathrm{mmol}$; $1.6 \mathrm{~m}$ in hexanes) and lactone D-11 (1.96, $10.3 \mathrm{mmol}$; dissolved in $25 \mathrm{~mL}$ dry THF) was subsequently added at $-80{ }^{\circ} \mathrm{C}$. The reaction mixture was stirred at $-80{ }^{\circ} \mathrm{C}$ for $90 \mathrm{~min}$ and afterwards allowed to reach room temperature and quenched by the addition of $\mathrm{AcOH}$ $(1 \mathrm{~mL})$, filtered and the solvent was evaporated in vacuo. Column chromatography (PE/EtOAc, 1/1) provided D-12 (2.32 g, 72\%) as colorless oil. The product was isolated as mixture of anomers in ratio 4:1. $[\alpha]_{D}^{20}=-6.7^{\circ}\left(\mathrm{c}=1.0, \mathrm{CHCl}_{3}\right) ; \mathrm{R}_{\mathrm{f}}=0.30(\mathrm{PE} / \mathrm{EtOAc}, 1 / 1) ;{ }^{1} \mathrm{H}-\mathrm{NMR}\left(300 \mathrm{MHz}, \mathrm{CDCl}_{3}\right) \delta=7.23-7.41$ (m 5H, H-Ar, both anomers), 4.48-4.73 (m, 2H, $\mathrm{CH}_{2} \mathrm{Ph}$, both anomers), 4.20-4.29 (m, 0.8H, H-5, major anomer), 4.07-4.17 (m, 0.2H, H-4, minor anomer), 4.01-4.05 (m, 0.2H, H-5, minor anomer), 3.89 (d, $J=5.1 \mathrm{~Hz}, 0.8 \mathrm{H}, \mathrm{H}-3$, major anomer), 3.78-3.85 (m, 0.8H, H-4, major anomer), $3.76(\mathrm{~d}, J=3.2 \mathrm{~Hz}, 0.2 \mathrm{H}$, $\mathrm{H}-3$, minor anomer), 3.29-3.68 (m, 13H, H-1a, H-1b, H-6a, H-6b, $\left.3 \times \mathrm{CH}_{3}\right)$; ${ }^{13} \mathrm{C}-\mathrm{NMR}\left(75 \mathrm{MHz}, \mathrm{CDCl}_{3}\right)$ $\delta=138.2,128.3,128.2,127.9,127.7,127.6,127.5$ (C-Ar), 104.8 (C-2, minor anomer), 102.8 (C-2, major anomer), 82.9 (C-3, minor anomer), 80.7 (C-5, minor anomer), 79.9 (C-4, minor anomer), 79.8 (C-4, major anomer), 79.1 (C-3, major anomer), 79.0 (C-5, major anomer), $73.7\left(\mathrm{CH}_{2} \mathrm{Ph}\right.$, minor anomer), $73.5\left(\mathrm{CH}_{2} \mathrm{Ph}\right.$, major anomer), 73.0 (C-6, minor anomer), 72.5 (C-6, major anomer), 71.1 (C-1, major anomer), 70.8 (C-1, minor anomer), $60.0\left(\mathrm{CH}_{3}\right.$, minor anomer $), 59.3\left(\mathrm{CH}_{3}\right.$, major anomer $), 59.2\left(\mathrm{CH}_{3}\right.$, minor anomer), $59.1\left(\mathrm{CH}_{3}\right.$, major anomer), $58.4\left(\mathrm{CH}_{3}\right.$, minor anomer $), 58.4\left(\mathrm{CH}_{3}\right.$, major anomer); HRMS (ESI-TOF) $m / z$ [M + Na $]^{+}$: calcd for $\mathrm{C}_{16} \mathrm{H}_{24} \mathrm{O}_{6} \mathrm{Na}$ : 335.14651, found: 335.14699; Anal calcd for $\mathrm{C}_{16} \mathrm{H}_{24} \mathrm{O}_{6}$ : C 61.52, $\mathrm{H}$ 7.74, found: C 61.05, $\mathrm{H} 7.84$.

3,4,6-Tri-O-methyl-1-O-benzyl-L-psicose (L-12): Prepared with the same protocol as described for D-12, from 4c (8.76 g, $21.3 \mathrm{mmol}), \mathbf{L - 1 1}(2.70,14.2 \mathrm{mmol})$ and $\mathrm{n}-\mathrm{BuLi}(16.0 \mathrm{~mL}, 25.6 \mathrm{mmol} ; 1.6 \mathrm{M} \mathrm{in}$ hexanes). Colorless oil, $(3.06 \mathrm{~g}, 69 \%)$ yield after column chromatography. $[\alpha]_{D}^{20}=+7.3^{\circ}\left(\mathrm{c}=1.0, \mathrm{CHCl}_{3}\right)$; $\mathrm{R}_{\mathrm{f}}$ and NMR data was identical to D-11; HRMS (ESI-TOF) $m / z[\mathrm{M}+\mathrm{Na}]^{+}$: calcd for $\mathrm{C}_{16} \mathrm{H}_{24} \mathrm{O}_{6} \mathrm{Na}$ : 335.14651, found: 335.14642; Anal calcd for $\mathrm{C}_{16} \mathrm{H}_{24} \mathrm{O}_{6}$ : C 61.52, H 7.74, found: C 61.53, H 7.87.

3,4,6-Tri-O-methyl-D-psicose (D-13): A mixture of D-12 (2.64 g, $8.45 \mathrm{mmol})$ and Pd (200 mg, $0.19 \mathrm{mmol} ; 10 \%$ on activated carbon) in degassed EtOH $(100 \mathrm{~mL})$ was stirred under an atmosphere of hydrogen for $3 \mathrm{~h}$. The reaction mixture was filtered through a pad of celite. After evaporation of the solvent in vacuo the residue was purified by column chromatography (EtOAc $\rightarrow$ EtOAc/i-PrOH 1/1) which provided $\mathbf{D}-\mathbf{1 3}(1.72 \mathrm{~g}, 92 \%)$ as a colorless oil. The product was isolated as mixture of anomers in ratio 4:1. $[\alpha]_{D}^{20}=+1.6^{\circ}\left(\mathrm{c}=1.0, \mathrm{CHCl}_{3}\right) ; \mathrm{R}_{\mathrm{f}}=0.60(\mathrm{EtOAc} / \mathrm{i}-\mathrm{PrOH}, 1 / 1) ;{ }^{1} \mathrm{H}-\mathrm{NMR}\left(400 \mathrm{MHz}, \mathrm{CDCl}_{3}\right)$ $\delta=4.32(\mathrm{~s}, 0.8 \mathrm{H}, \mathrm{OH}$, major anomer), 4.19-4.22 (m, 0.8H, H-5, major anomer), 4.12-4.18 (m, 0.2H, $\mathrm{H}-5$, minor anomer), 4.02-4.06 (m, 0.2H, H-4, minor anomer), 3.91-3.96 (m, 0.8H, H-4, major anomer), 3.87-3.90 (m, 0.8H, H-3, major anomer), 3.78-3.81 (m, 0.2H, H-3, minor anomer), 3.74 (s, 0.2H, OH, minor anomer), 3.32-3.68 (m, 13H, H-1a, H-1b, H-6a, H-6b, $\left.3 \times \mathrm{CH}_{3}\right), 2.50$ (bs, 1H, OH); ${ }^{13} \mathrm{C}-\mathrm{NMR}$ $\left(101 \mathrm{MHz}, \mathrm{CDCl}_{3}\right) \delta=105.2$ (C-2, minor anomer), 103.4 (C-2, major anomer), 83.9 (C-3, minor anomer), 80.7 (C-4, minor anomer), 80.2 (C-5, minor anomer), 80.2 (C-4, major anomer), 79.3 (C-3, major anomer), 
79.2 (C-5, major anomer), 72.7 (C-6, minor anomer), 72.1 (C-6, major anomer), 64.8 (C-1, major anomer), 64.2 (C-1, minor anomer), $60.0\left(\mathrm{CH}_{3}\right.$, minor anomer $), 59.6\left(\mathrm{CH}_{3}\right.$, major anomer $), 59.3\left(\mathrm{CH}_{3}\right.$, minor anomer), $59.3\left(\mathrm{CH}_{3}\right.$, major anomer), $58.6\left(\mathrm{CH}_{3}\right.$, major anomer $), 58.5\left(\mathrm{CH}_{3}\right.$, minor anomer); HRMS (ESI-TOF) $m / z$ [M + Na] ${ }^{+}$: calcd for $\mathrm{C}_{9} \mathrm{H}_{18} \mathrm{O}_{6} \mathrm{Na}$ : 245.09956, found: 245.09987; Anal calcd for $\mathrm{C}_{9} \mathrm{H}_{18} \mathrm{O}_{6}$ : C 48.64, H 8.16, found: C 48.39, H 7.84.

3,4,6-Tri-O-methyl-L-psicose (L-13): Prepared with the same protocol as described for $\mathbf{D}-\mathbf{1 3}$, from L-12 (1.47 g, $4.70 \mathrm{mmol})$ and Pd (150 mg, $0.14 \mathrm{mmol} ; 10 \%$ on activated carbon). Colorless oil, (971 mg, $93 \%$ ) yield after column chromatography. $[\alpha]_{D}^{20}=-0.7^{\circ}\left(\mathrm{c}=1.0, \mathrm{CHCl}_{3}\right) ; \mathrm{R}_{\mathrm{f}}$ and NMR data was identical to D-11; HRMS (ESI-TOF) $\mathrm{m} / z$ [M + Na] ${ }^{+}$: calcd for $\mathrm{C}_{9} \mathrm{H}_{18} \mathrm{O}_{6} \mathrm{Na}$ : 245.09956, found: 245.09987; Anal calcd for $\mathrm{C}_{9} \mathrm{H}_{18} \mathrm{O}_{6}$ : C 48.64, $\mathrm{H}$ 8.16, found: C 48.83, $\mathrm{H}$ 8.24.

1,2-O-Isopropylidene-3,4,6-tri-O-methyl- $\alpha$-D-psicofuranosid (D-14) and 1,2-O-isopropylidene3,4,6-tri-O-methyl- $\beta$-D-psicofuranosid (D-15): To a solution of $\mathbf{D}-13$ (26 mg, $0.117 \mathrm{mmol})$ in dry acetone $(1 \mathrm{~mL})$ para-toluene sulfonic acid $(2.3 \mathrm{mg}, 0.012 \mathrm{mmol}$; monohydrate) was added and the resulting mixture was stirred at room temperature for $20 \mathrm{~h}$. The reaction mixture was alkalized by the addition of $\mathrm{NH}_{3}\left(0.1 \mathrm{~mL} ; 25 \%\right.$ in $\left.\mathrm{H}_{2} \mathrm{O}\right)$ and the solvent was evaporated in vacuo. Column chromatography $(\mathrm{PE} / \mathrm{EtOAc}, 1 / 1 \rightarrow 1 / 3)$ afforded both anomers in two different fractions. Eluted first: D-14 $(22 \mathrm{mg}, 70 \%)$ as a colorless oil. $[\alpha]_{D}^{20}=-35.3^{\circ}\left(\mathrm{c}=1.0, \mathrm{CHCl}_{3}\right) ; \mathrm{R}_{\mathrm{f}}=0.56(\mathrm{PE} / \mathrm{EtOAc}, 1 / 1) ;{ }^{1} \mathrm{H}-\mathrm{NMR}\left(400 \mathrm{MHz}, \mathrm{CDCl}_{3}\right)$ $\delta=4.26(\mathrm{~d}, J=9.7 \mathrm{~Hz}, 1 \mathrm{H}, \mathrm{H}-1 \mathrm{a}), 4.05-4.09(\mathrm{~m}, 1 \mathrm{H}, \mathrm{H}-5), 3.97$ (d, J = 9.7 Hz, 1H, H-1b), 3.78-3.83 $(\mathrm{m}, 1 \mathrm{H}, \mathrm{H}-4), 3.76(\mathrm{~d}, J=4.5 \mathrm{~Hz}, 1 \mathrm{H}, \mathrm{H}-3), 3.56\left(\mathrm{~s}, 3 \mathrm{H}, \mathrm{CH}_{3} \mathrm{O}\right), 3.50$ (d, J = 5.1 Hz, 2H, H-6a, H-6b), $3.44\left(\mathrm{~s}, 3 \mathrm{H}, \mathrm{CH}_{3} \mathrm{O}\right), 3.40\left(\mathrm{~s}, 3 \mathrm{H}, \mathrm{CH}_{3} \mathrm{O}\right), 1.48\left(\mathrm{~s}, 3 \mathrm{H}, \mathrm{CH}_{3} \mathrm{C}\right), 1.40\left(\mathrm{~s}, 3 \mathrm{H} \mathrm{CH}_{3} \mathrm{C}\right) ;{ }^{13} \mathrm{C}-\mathrm{NMR}(101 \mathrm{MHz}$, $\left.\mathrm{CDCl}_{3}\right) \delta=111.8\left(\mathrm{C}\left(\mathrm{CH}_{3}\right)_{2}\right), 110.5(\mathrm{C}-2), 82.3(\mathrm{C}-3), 81.1(\mathrm{C}-4), 79.3(\mathrm{C}-5), 74.0(\mathrm{C}-6), 69.7$ (C-1), 59.8, 59.4, $58.4\left(\mathrm{CH}_{3} \mathrm{O}\right), 26.3,26.1\left(\mathrm{C}\left(\mathrm{CH}_{3}\right)_{2}\right)$; HRMS (ESI-TOF) $\mathrm{m} / z$ [M $\left.+\mathrm{Na}\right]^{+}$: calcd for $\mathrm{C}_{12} \mathrm{H}_{22} \mathrm{O}_{6} \mathrm{Na}: 285.13086$, found: 285.13089 . Eluted second: $\mathbf{D}-15(4.8 \mathrm{mg}, 16 \%)$ as a colorless oil. $[\alpha]_{D}^{20}=+10.5^{\circ}\left(\mathrm{c}=1.0, \mathrm{CHCl}_{3}\right)$; $\mathrm{R}_{\mathrm{f}}=0.20(\mathrm{PE} / \mathrm{EtOAc}, 1 / 1) ;{ }^{1} \mathrm{H}-\mathrm{NMR}\left(400 \mathrm{MHz}, \mathrm{CDCl}_{3}\right) \delta=4.23-4.26(\mathrm{~m}, 1 \mathrm{H}, \mathrm{H}-5), 4.08(\mathrm{~d}, J=9.1 \mathrm{~Hz}$, $1 \mathrm{H}, \mathrm{H}-1 \mathrm{a}), 4.03$ (d, J = 9.1 Hz, 1H, H-1b), 3.77 (dd, $J=6.4,2.9 \mathrm{~Hz}, 1 \mathrm{H}, \mathrm{H}-4), 3.59$ (d, J = 6.4 Hz, $1 \mathrm{H}$, $\mathrm{H}-3), 3.52\left(\mathrm{~s}, 3 \mathrm{H}, \mathrm{CH}_{3} \mathrm{O}\right), 3.48(\mathrm{~d}, J=3.9 \mathrm{~Hz}, 2 \mathrm{H}, \mathrm{H}-6 \mathrm{a}, \mathrm{H}-6 \mathrm{~b}), 3.44\left(\mathrm{~s}, 3 \mathrm{H}, \mathrm{CH}_{3} \mathrm{O}\right), 3.38\left(\mathrm{~s}, 3 \mathrm{H}, \mathrm{CH}_{3} \mathrm{O}\right)$,

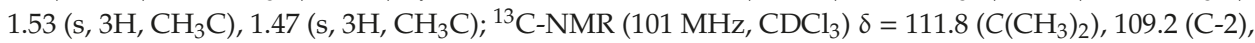
81.0 (C-5), 80.2 (C-3), 78.2 (C-4), $\left.73.2(\mathrm{C}-6), 71.8(\mathrm{C}-1), 59.5,58.7,58.5\left(\mathrm{CH}_{3} \mathrm{O}\right), 26.6,26.3\left(\mathrm{C}^{\left(\mathrm{CH}_{3}\right)}\right)_{2}\right)$; HRMS (ESI-TOF) $m / z$ [M + Na] $]^{+}$: calcd for $\mathrm{C}_{12} \mathrm{H}_{22} \mathrm{O}_{6} \mathrm{Na}$ : 285.13086, found: 285.13106; Anal calcd for $\mathrm{C}_{12} \mathrm{H}_{22} \mathrm{O}_{6:}$ : $54.95, \mathrm{H} 8.45$, found: C 54.47, $\mathrm{H} 8.28$.

1,2-O-Isopropylidene-3,4,6-tri-O-methyl- $\alpha$-L-psicofuranosid (L-14) and 1,2-O-isopropylidene-3,4,6tri-O-methyl- $\beta$-L-psicofuranosid (L-15): Prepared with the same protocol as described for $\mathbf{D}-\mathbf{1 4}$ and $\mathbf{D}-\mathbf{1 5}$, from L-13 (148 mg, $0.666 \mathrm{mmol}$ ) and para-toluene sulfonic acid (12.6 mg, $0.066 \mathrm{mmol}$; monohydrate). Eluted first: $\mathbf{L}-14(124 \mathrm{mg}, 71 \%)$ as a colorless oil. $[\alpha]_{D}^{20}=+37.6^{\circ}\left(\mathrm{c}=1.0, \mathrm{CHCl}_{3}\right) ; \mathrm{R}_{\mathrm{f}}$ and NMR data was identical to D-14; HRMS (ESI-TOF) $m / z$ [M + Na] ${ }^{+}$: calcd for $\mathrm{C}_{12} \mathrm{H}_{22} \mathrm{O}_{6} \mathrm{Na}$ : 285.13086, found: 285.13097; Anal calcd for $\mathrm{C}_{12} \mathrm{H}_{22} \mathrm{O}_{6}$ : C 54.95, H 8.45, found: C 55.62, H 8:72. Eluted second: $\mathbf{L}-\mathbf{1 5}$ (30 mg, 17\%) as a colorless oil. $[\alpha]_{D}^{20}=-9.2^{\circ}\left(\mathrm{c}=1.0, \mathrm{CHCl}_{3}\right) ; \mathrm{R}_{\mathrm{f}}$ and NMR data was identical to $\mathbf{D}-15$; HRMS (ESI-TOF) $m / z[\mathrm{M}+\mathrm{Na}]^{+}$: calcd for $\mathrm{C}_{12} \mathrm{H}_{22} \mathrm{O}_{6} \mathrm{Na}: 285.13086$, found: 285.13110 ; Anal calcd for $\mathrm{C}_{12} \mathrm{H}_{22} \mathrm{O}_{6}: 54.95$, H 8.45, found: C 55.18, H 8.45.

\section{Conclusions}

In summary, we describe a method to prepare derivatives of both enantiomers of rare ketoses (i.e., psicose) from inexpensively ribose. The ketoses have the protecting groups necessary for the synthesis of ligands for asymmetric catalysis. With other inexpensive commercially available pentoses like for instance L-arabinose $(100 \mathrm{~g}, 144 €)$ or D-xylose $(1 \mathrm{~kg}, 57 €)$ derivatives of other rare ketoses like L-fructose (50 mg, $126 €)$, or D-sorbose (100 mg, $224 €$ ) are accessible [24]. By using the benzylated lactone 8 in the sequence shown in Schemes 3 and 4, the completely deprotected psicose should be obtained after the reduction under an atmosphere of hydrogen. Since the methyl groups are hard to remove, other protective groups like MEM or TIPS at the carbohydrate may be used if an easily removable to benzyl orthogonal protective group is needed. 
Supplementary Materials: Supplementary information (copies of NMR spectra) is available online.

Author Contributions: Experiment design, M.R.I. and T.Z.; experiment performance, M.R.I.; data interpretation, M.R.I.; writing—original draft preparation, M.R.I.; writing—review and editing, M.R.I., T.Z.; supervision, T.Z.

Funding: This research received no external funding.

Acknowledgments: The work of Anna Stroppel (proofreading the manuscript), Petra Schülzle (elemental analysis) and Dorothee Wistuba (HRMS) is gratefully acknowledged.

Conflicts of Interest: The authors declare no conflict of interest.

\section{References and Notes}

1. Wen, L.; Huang, K.; Wei, M.; Meisner, J.; Liu, Y.; Garner, K.; Zang, L.; Wang, X.; Li, X.; Fang, J.; et al. Facile Enzymatic Synthesis of Ketoses. Angew. Chem. Int. Ed. 2015, 54, 12654-12658. [CrossRef] [PubMed]

2. Huwig, A.; Emmel, S.; Jäkel, G.; Giffhorn, F. Enzymatic synthesis of L-tagatose from galactitol with galactitol dehydrogenase from Rhodobacter sphaeroides D. Carbohydr. Res. 1997, 305, 337-339. [CrossRef]

3. Li, Z.; Gao, Y.; Nakanishi, H.; Gao, X.; Cai, L. Biosynthesis of rare hexoses using microorganisms and related enzymes. Beilstein J. Org. Chem. 2013, 9, 2434-2445. [CrossRef] [PubMed]

4. Ekeberg, D.; Morgenlie, S.; Stenstrøm, Y. Aldose-ketose interconversion in pyridine in the presence of aluminium oxide. Carbohydr. Res. 2007, 342, 1992-1997. [CrossRef]

5. Doner, L.W. Isomerization of D-fructose by base: liquid-chromatographic evaluation and the isolation of D-psicose. Carbohydr. Res. 1979, 70, 209-216. [CrossRef]

6. Mukaiyama, T.; Yuki, Y.; Suzuki, K. The steroselective synthesis of L-Tagatose-an application of Zn (II) mediated highly stereoselective addition of 2-furyllithium to polyoxygenated aldehyde. Chem. Lett. 1982, 11, 1169-1170.

7. Matsumoto, T.; Enomoto, T.; Kurosaki, T. Facile synthesis of the next higher ketoses from aldoses. Chem. Commun. 1992, 610-611. [CrossRef]

8. Chattopadhyay, S.; Raychaudhuri, U.; Chakraborty, R. Artificial sweeteners-a review. J. Food Sci. Technol. 2014, 51, 611-621. [CrossRef]

9. Imrich, M.R.; Biehler, L.E.; Maichle-Mössmer, C.; Ziegler, T. Carbohydrate-Based Chiral Iodoarene Catalysts: A Survey through the Development of an Improved Catalyst Design. Molecules 2019, 24, 3883. [CrossRef]

10. Imrich, M.R.; Kraft, J.; Maichle-Mössmer, C.; Ziegler, T. D-Fructose-based spiro-fused PHOX ligands: synthesis and application in enatioselective allylic alkylation. Beilstein J. Org. Chem. 2018, 14, 2082-2089. [CrossRef]

11. Imrich, M.R.; Maichle-Mössmer, C.; Ziegler, T. D-Fructose based spiro-fused PHOX ligands: Palladium complexes and application in catalysis. Eur. J. Org. Chem. 2019, 3955-3963. [CrossRef]

12. Imrich, M.R.; Ziegler, T. Carbohydrate based chiral iodoarene catalysts for enantioselective dearomative spirocyclization. Tetrahedron Lett. 2019, 60, 150954. [CrossRef]

13. Price found at www.sigmaaldrich.com on 17 September 2019.

14. Bols, M.; Szarek, W.A. Synthesis of 3-deoxy-3-fluoro-D-fructose. J. Chem. Soc. Chem. Commun. 1992, 445-446. [CrossRef]

15. Bols, M.; Grubbe, H.; Jespersen, T.M.; Szarek, W.A. Hydroxymethylation of aldonolactones and a chemical synthesis of 3-deoxy-3-fluoro-d-fructose. Carbohydr. Res. 1994, 253, 195-206. [CrossRef]

16. Shiozaki, M. Conversion of D-glucose to L-glucose: oxidative decarboxylation of alpha-oxycarboxylic acids via their diacyl peroxides. J. Org. Chem. 1991, 56, 528-532. [CrossRef]

17. Martin, O.R.; Saavedra, O.M. Concise chemical synthesis of $\beta$-homonojirimycin and related compounds. Tetrahedron Lett. 1995, 36, 799-802. [CrossRef]

18. Van Rijssel, E.R.; van Delft, P.; van Marle, D.V.; Bijvoets, S.M.; Lodder, G.; Overkleeft, H.S.; van der Marel, G.A.; Filippov, D.V.; Codée, J.D.C. Stereoselectivity in the Lewis Acid Mediated Reduction of Ketofuranoses. J. Org. Chem. 2015, 80, 4553-4565. [CrossRef]

19. Meyer, N.; Seebach, D. Doppelt metalliertes Methanol. Alkohol-d $\mathrm{d}^{1}-\mathrm{und}_{-\mathrm{d}} \mathrm{d}^{-R e a g e n z i e n .}$ Chem. Ber. 1980, 113, 1290-1303. [CrossRef]

20. Corey, E.; Gras, J.L.; Ulrich, P. A new general method for protection of the hydroxyl function. Tetrahedron Lett. 1976, 17, 809-812. [CrossRef] 
21. Nicolaou, K.C.; Snyder, S.A.; Longbottom, D.A.; Nalbandian, A.Z.; Huang, X. New Uses for the Burgess Reagent in Chemical Synthesis: Methods for the Facile and Stereoselective Formation of Sulfamidates, Glycosylamines, and Sulfamides. Chem. Eur. J. 2004, 10, 5581-5606. [CrossRef]

22. Lohse-Fraefel, N.; Carreira, E.M. Polyketide building blocks via diastereoselective nitrile oxide cycloadditions with homoallylic alcohols and monoprotected homoallylic diols. Chem. Eur. J. 2009, 15, 12065-12081. [CrossRef] [PubMed]

23. Di Bussolo, V.; Fiasella, A.; Romano, M.R.; Favero, L.; Pineschi, M.; Crotti, P. Stereoselective synthesis of 2, 3-unsaturated-aza-O-glycosides via new diastereoisomeric $\mathrm{N}-\mathrm{Cbz}$-imino glycal-derived allyl epoxides. Org. Lett. 2007, 9, 4479-4482. [CrossRef] [PubMed]

24. Price found at www.sigmaaldrich.com on 23 September 2019.

(C) 2019 by the authors. Licensee MDPI, Basel, Switzerland. This article is an open access article distributed under the terms and conditions of the Creative Commons Attribution (CC BY) license (http://creativecommons.org/licenses/by/4.0/). 


\title{
$5^{\prime}$-Chloro-5'-deoxy-2', $3^{\prime}$-O-isopropylidene-6-fluoro
} nebularine

\author{
Andrea Patrizia Falanga ${ }^{1}$, Maria Marzano ${ }^{2}$, Monica Terracciano ${ }^{2}$ and Stefano D’Errico ${ }^{2, *}$ \\ 1 Department of Molecular Medicine and Medical Biotechnology, University of Naples Federico II, via Sergio \\ Pansini, 5, 80131 Napoli, Italy; andreapatrizia.falanga@unina.it \\ 2 Department of Pharmacy, University of Naples Federico II, via Domenico Montesano, 49, 80131 Napoli, Italy; \\ maria.marzano@unina.it (M.M.); monica.terracciano@unina.it (M.T.) \\ * Correspondence: stefano.derrico@unina.it; Tel.: +39-081-679981
}

Received: 20 November 2019; Accepted: 10 December 2019; Published: 13 December 2019

\begin{abstract}
In this paper, we report on the synthesis and spectroscopic characterization of the novel nucleoside $5^{\prime}$-chloro- $5^{\prime}$-deoxy-2', $3^{\prime}$-O-isopropylidene-6-fluoro nebularine, obtained as a side product during the second step of the synthesis of $5^{\prime}$-fluoro- $5^{\prime}$-deoxy-5-aminoimidazole-4-carboxamide- $\beta$-Driboside (5'-F-AICAR), a non-phosphorylable analogue of 5 -aminoimidazole-4-carboxamide- $\beta$-Driboside (AICAR).
\end{abstract}

Keywords: AICAR; acadesine; phosphorylation; fluorination; fluorinated nucleosides; nucleoside analogues; modified nucleosides; chlorinated nucleosides; AMPK

\section{Introduction}

Nucleoside and nucleotide analogues are synthetic modified compounds that have been developed to mimic their physiological counterparts [1]. Considering that several nucleoside and nucleotide analogues have been approved by the Food and Drug Administration (FDA) for the treatment of viral and cancer diseases and others have entered clinical trials [2,3], many research groups have focused their attention on the preparation of novel compounds to expand the pool of molecules with potential biological activities, with the aim of discovering "leads" that are safer and more effective. For example, the replacement of $\mathrm{OH}$ groups of sugar moieties with the isosteric $\mathrm{F}$ atom has generated life-saving drugs for the treatment of infectious diseases, such as HIV [4], HBV [5], and HCV [6].

The nucleoside AICAR (1, Figure 1), besides being an intermediate involved in purine biosynthesis, is an activator of the enzyme adenosine monophosphate-activated protein kinase (AMPK) in the $5^{\prime}$-phosphorylated form $[7,8]$. This activation leads to a cascade of metabolic events, such as the inhibition of basal and insulin-stimulated glucose uptake, lipogenesis, and glucose oxidation [9]. The AMPK pathway is also implicated in the regulation of cell proliferation, and activation by AICAR could result in pro-apoptotic effects [10]. Given the importance of such a molecule, the synthesis of novel AICAR analogues is an appealing goal to better understand its mechanism of action [11-15]. Considering AICAR's low intestinal absorption and poor penetration of the blood-brain barrier, we synthesized a more lipophilic analogue, where the $5^{\prime}-\mathrm{OH}$ group was replaced by a fluorine atom (2, 5'-F-AICAR) [16].

For the preparation of nucleoside 2, a key step was the $5^{\prime}$-fluorination of compound 4 (Scheme 1) [16]. In this paper, we report on the synthesis and structural characterization of the novel nucleoside 8 (Scheme 2), obtained by a side reaction during the fluorination step. This nucleoside could represent a valuable intermediate for a modular derivatization of the purine base moiety and the sugar residue. 

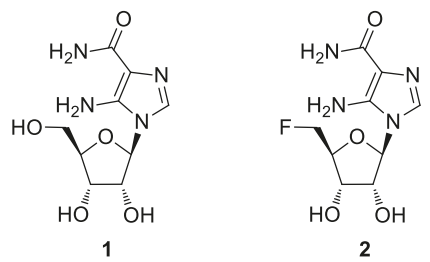

Figure 1. Structures of AICAR (1) and 5'-F-AICAR (2).

\section{Results and Discussion}

For the synthesis of $5^{\prime}$-F-AICAR (2), we used as the starting material the commercially available 6-chloronebularine ( 3 , Scheme 1$)$, which was readily transformed into its $2^{\prime}, 3^{\prime}-O$-isopropylidene derivative 4 [17]. After $5^{\prime}$-fluorination, the 6-chloropurine was converted into hypoxanthine and the obtained nucleoside 6 transformed into the derivative 7. The strong electron-withdrawing 2,4-dinitrophenyl group, introduced at the N1 hypoxanthine position, allowed us to obtain the 5'-F-AICAR 2 through a 1,2-diaminoethane-mediated purine ring degradation [18].

In the second step of the synthesis, the $5^{\prime}-\mathrm{OH}$ group of nucleoside 4 was replaced by a $5^{\prime}-\mathrm{F}$ in a one-pot tosylation/fluorination sequence, through the treatment with the tosyl fluoride/tetrabutylammonium fluoride (TsF/TBAF) reagent system with tetrahydrofuran (THF) as solvent, according to Shimizu's procedure [19]. As previously observed by Ashton and Scammells [19], we noted (TLC monitoring in $n$-hexane/AcOEt; $1: 1$ ) that the process led not only to the formation of the expected fluorinated product $5 \mathbf{a}$ with $\mathrm{Rf}=0.48$ (Scheme 1), but also to the formation of the bis-fluorinated product $5 \mathbf{b}$ with $\mathrm{Rf}=0.42$, as a consequence of the substitution in species 4 of the $\mathrm{C} 6$ chlorine atom by a fluoride ion.

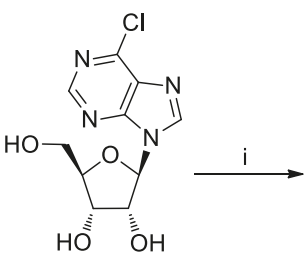

3

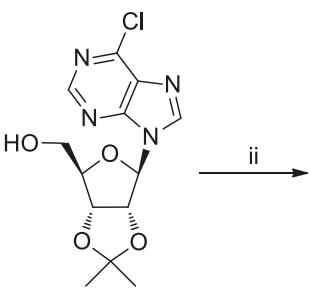

4

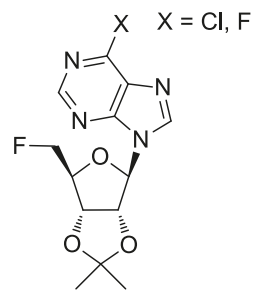

$5 \mathrm{a}, \mathrm{X}=\mathrm{Cl}$

5b, $X=F$

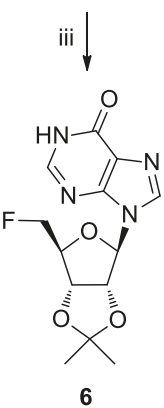

Scheme 1. Reagents and conditions: (i) acetone, 2,2-dimethoxypropane (DMP), $p$-toluensulfonic acid ( $p$-TsOH), 2 h, r.t.; (ii) TsF, TBAF, THF, reflux, 18 h; (iii) $0.1 \mathrm{M} \mathrm{NaOH}, 4$ h, r.t.; (iv), $\mathrm{K}_{2} \mathrm{CO}_{3}$, 1-chloro-2,4-dinitrobenzene, $\mathrm{N}, \mathrm{N}$-dimethylformamide (DMF), $3 \mathrm{~h}, 80^{\circ} \mathrm{C}$; (v) 1,2-diaminoethane, DMF, $16 \mathrm{~h}, 50{ }^{\circ} \mathrm{C}$; (vi) $50 \%$ trifluoracetic acid (TFA) in $\mathrm{H}_{2} \mathrm{O}, 4 \mathrm{~h}$. 


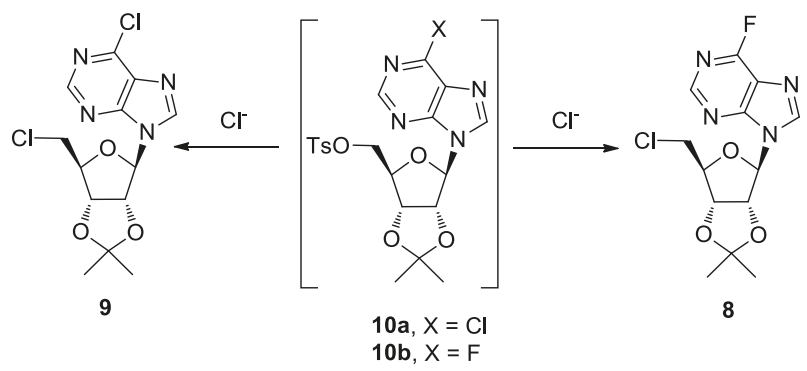

Scheme 2. Proposed mechanisms for the formation of nucleosides 8 and 9.

The TLC also showed a third spot with $\mathrm{Rf}=0.52$, whose corresponding product was isolated (10\% yield) and analyzed by ${ }^{1} \mathrm{H}-\mathrm{NMR}$. The spectrum evidenced the presence of two compounds in a ratio of 1:8, which were resolved only by means of high-performance liquid chromatography (HPLC). The nucleoside in lower amounts and with $\mathrm{Rt}=21.2 \mathrm{~min}$ was assigned as the novel 5'-chloro-5'-deoxy-2', 3'-O-isopropylidene-6-fluoro nebularine (8, Scheme 2). Its structure was established through 1D-, 2D-NMR, and HRESI-MS experiments (see Supplementary Materials). In detail, in the ${ }^{1} \mathrm{H}-\mathrm{NMR}$ spectrum the $5^{\prime}-\mathrm{H}_{\mathrm{a}, \mathrm{b}}$ protons resonated as two doublets of doublets at 3.81 and $3.70 \mathrm{ppm}$, whereas in the ${ }^{13} \mathrm{C}-\mathrm{NMR}$ spectrum the $5^{\prime} \mathrm{C}$ carbon resonated at $43.4 \mathrm{ppm}$. These data were consistent with the presence of a $5^{\prime} \mathrm{C}-\mathrm{Cl}$ bond [20]. In the HMBC spectrum, the 2-H proton at $8.69 \mathrm{ppm}$ correlated with the $\mathrm{C} 6$ purine carbon at $159.9 \mathrm{ppm}$, which appeared as a doublet with $J=261.8 \mathrm{~Hz}$, as a consequence of the coupling with the $\mathrm{F}$ atom.

A similar compound, with the $2^{\prime}$ - and $3^{\prime}$-ribose hydroxyls protected as acetates, was synthesized by Robins et al. [21] and used to obtain fluorescent probes for detecting the cellular uptake of the drug gemcitabine.

The main component with $\mathrm{Rt}=24.2 \mathrm{~min}$ was instead identified as the known $5^{\prime}$-chloro-5'-deoxy$2^{\prime}, 3^{\prime}$-O-isopropylidene-6-chloro nebularine 9 [20].

A plausible mechanism for the formation of compounds $\mathbf{8}$ and $\mathbf{9}$ is described in Scheme 2. The $\mathrm{Cl}^{-}$ ions, derived from the partial $\mathrm{Cl}^{-} / \mathrm{F}^{-}$exchange at the $\mathrm{C} 6$ purine position during the $5^{\prime}$-fluorination step, yielded the nucleosides 8 and 9 by $\mathrm{S}_{\mathrm{N}} 2$ displacement of the tosylate groups in the intermediates $10 \mathrm{~b}$ and 10a, respectively.

\section{Materials and Methods}

All the reagents and solvents for the chemical syntheses were obtained from commercial sources and used without further purification. The ${ }^{1} \mathrm{H}-,{ }^{19} \mathrm{~F}$ - and ${ }^{13} \mathrm{C}-\mathrm{NMR}$ spectra were acquired on $400 / 700 \mathrm{MHz}$ instruments (Bruker, Billerica, MA, USA) using $\mathrm{CDCl}_{3}$ as the solvent. The chemical shifts were reported in parts per million ( $)$ relative to the residual solvent signal $\left({ }^{1} \mathrm{H}: \mathrm{CHCl}_{3} 7.27\right.$; ${ }^{13} \mathrm{C}: \mathrm{CDCl}_{3}$ 77.0) and assigned by 2D-NMR experiments. All the NMR spectra were processed using the iNMR software package (Nucleomatica, Molfetta, Italy). The HRESI-MS spectra were recorded in positive mode on a Thermo Orbitrap XL mass spectrometer (ThermoFisher, Waltham, MA, USA). The column chromatography was performed by using silica gel 60, 70-230 mesh (Merck, Darmstadt, Germany). The TLC analyses were performed using $0.2 \mathrm{~mm}$ thick F254 silica gel plates (Merck, Darmstadt, Germany). The TLC spots were detected under UV light $(254 \mathrm{~nm})$. The high-performance liquid chromatography (HPLC) was performed on a UP-2075 Plus pump equipped with a UV-2075 Plus UV detector (Jasco, Cremella, Italy) using a $5 \mu \mathrm{m}, 250-10$ Si column (Purosphere ${ }^{\circledR}$ STAR, Merck, Darmstadt, Germany) eluted with $n$-hexane/AcOEt, $6: 4$ with a flow rate of $2.0 \mathrm{~mL} / \mathrm{min}$.

5'-Chloro-5'-deoxy-2', 3'-O-isopropylidene-6-fluoro nebularine (8). To a stirred solution of 4 (0.28 g, $0.86 \mathrm{mmol})$ in dry THF $(7.5 \mathrm{~mL}), \mathrm{TsF}(0.30 \mathrm{~g}, 1.7 \mathrm{mmol})$ and TBAF $(2.6 \mathrm{~mL}$ of a $1.0 \mathrm{M}$ solution in dry THF, $2.6 \mathrm{mmol}$ ) were added and the mixture refluxed for $16 \mathrm{~h}$ (TLC monitoring: $n$-hexane/AcOEt; 1:1). 
The solvent was removed under reduced pressure and the crude residue purified by silica gel flash chromatography ( $n$-hexane/AcOEt, 6:4) to afford, in addition to the two expected compounds 5 a and $5 b$ [19], the inseparable mixture of the two nucleosides 8 and 9 with $\mathrm{Rf}=0.52$ (10\% yield). The mixture was purified by HPLC (see above), thus obtaining the pure compound 8 . Colorless foam $(3.5 \mathrm{mg}, 1.2 \%$ yield). ${ }^{1} \mathrm{H}-\mathrm{NMR}\left(400 \mathrm{MHz} ; \mathrm{CDCl}_{3}\right): \delta 8.69(\mathrm{~s}, 1 \mathrm{H}, 2-\mathrm{H}), 8.29(\mathrm{~s}, 1 \mathrm{H}, 8-\mathrm{H}), 6.24\left(\mathrm{~d}, J=2.6 \mathrm{~Hz}, 1 \mathrm{H}, 1^{\prime}-\mathrm{H}\right)$, $5.40\left(\mathrm{dd}, J=6.4,2.7 \mathrm{~Hz}, 1 \mathrm{H}, 2^{\prime}-\mathrm{H}\right), 5.13\left(\mathrm{dd}, J=6.4,3.1 \mathrm{~Hz}, 1 \mathrm{H}, 3^{\prime}-\mathrm{H}\right), 4.58-4.55\left(\mathrm{~m}, 1 \mathrm{H}, 4^{\prime}-\mathrm{H}\right), 3.82$ $\left(\mathrm{dd}, J=11.6,6.1 \mathrm{~Hz}, 1 \mathrm{H}, 5^{\prime}-\mathrm{H}_{\mathrm{a}}\right), 3.70\left(\mathrm{dd}, J=11.6,4.9 \mathrm{~Hz}, 1 \mathrm{H}, 5^{\prime}-\mathrm{H}_{\mathrm{b}}\right), 1.66\left(\mathrm{~s}, 3 \mathrm{H}, \mathrm{CH}_{3}\right), 1.42(\mathrm{~s}, 3 \mathrm{H}$, $\left.\mathrm{CH}_{3}\right) ;{ }^{19} \mathrm{~F}-\mathrm{NMR}\left(377 \mathrm{MHz} ; \mathrm{CDCl}_{3}\right): \delta-68.4(\mathrm{~s}) ;{ }^{13} \mathrm{C}-\mathrm{NMR}\left(176 \mathrm{MHz} ; \mathrm{CDCl}_{3}\right): \delta 159.9(\mathrm{~d}, J=261.8,6-\mathrm{C})$, $154.5(\mathrm{~d}, J=11.1,4-\mathrm{C}), 152.2(\mathrm{~d}, J=14.3,2-\mathrm{C}), 144.0(8-\mathrm{C}), 121.15(\mathrm{~d}, J=29.2,5-\mathrm{C}), 115.1$ (C $\mathrm{q}$ acetonide), $91.3\left(1^{\prime}-\mathrm{C}\right), 86.2\left(4^{\prime}-\mathrm{C}\right), 84.2\left(2^{\prime}-\mathrm{C}\right), 82.3\left(3^{\prime}-\mathrm{C}\right), 43.9\left(\mathrm{CH}_{2} \mathrm{Cl}\right), 27.1\left(\mathrm{CH}_{3}\right), 25.3\left(\mathrm{CH}_{3}\right)$; HRESI-MS m/z 329.0809, $\left([\mathrm{M}+\mathrm{H}]^{+}\right.$calcd. for $\left.\mathrm{C}_{13} \mathrm{H}_{15} \mathrm{ClFN}_{4} \mathrm{O}_{3} 329.0817\right)$.

Supplementary Materials: The following are available online, Figure S1: copies of ${ }^{1} \mathrm{H}$ - and ${ }^{19} \mathrm{~F}-\mathrm{NMR}$ spectra of compound 8; Figure S2: copy of ${ }^{13} \mathrm{C}-\mathrm{NMR}$ spectrum of compound 8; Figure S3: copy of HMBC spectrum of compound 8; Figure S4: copy of HRESI-MS spectrum of compound 8.

Author Contributions: S.D. conceived and designed the experiments; A.P.F. performed the synthetic experiments; M.M. performed the spectroscopic experiments; M.T. analyzed the data; S.D. wrote the paper. All authors read and approved the final manuscript.

Funding: This research was funded by "Campania Onco Terapie - Combattere la resistenza tumorale: piattaforma integrata multidisciplinare per un approccio tecnologico innovativo alle oncoterapie" - POR Campania FESR 2014/2020 O.S. 1.2 Az. 1.2.2 Avviso per Manifestazione di interesse per la Realizzazione di Technology Platform nell'ambito della lotta alle patologie oncologiche CUP B61G18000470007".

Acknowledgments: The authors are grateful to Luisa Cuorvo for her technical assistance.

Conflicts of Interest: The authors declare no conflict of interest.

\section{References}

1. Burke, M.; Borland, K.; Litosh, V. Base-modified nucleosides as chemotherapeutic agents: Past and future. Curr. Top. Med. Chem. 2016, 16, 1231-1241. [CrossRef]

2. Berdis, A.J. Inhibiting DNA polymerases as a therapeutic intervention against cancer. Front. Mol. Biosci. 2017, 4, 78. [CrossRef]

3. De Clercq, E.; Li, G. Approved antiviral drugs over the past 50 years. Clin. Microbiol. Rev. 2016, 29, 695-747. [CrossRef]

4. Andreatta, K.; Willkom, M.; Martin, R.; Chang, S.; Wei, L.; Liu, H.; Liu, Y.-P.; Graham, H.; Quirk, E.; Martin, H.; et al. Switching to bictegravir/emtricitabine/tenofovir alafenamide maintained HIV-1 RNA suppression in participants with archived antiretroviral resistance including M184V/I. J. Antimicrob. Chemother. 2019, 74, 3555-3564. [CrossRef]

5. Zhang, J.; Wang, Y.; Peng, Y.; Qin, C.; Liu, Y.; Li, J.; Jiang, J.; Zhou, Y.; Chang, J.; Wang, Q. Novel fluoronucleoside analog NCC inhibits lamivudine-resistant hepatitis B virus in a hepatocyte model. Brazilian J. Infect. Dis. 2018, 22, 477-486. [CrossRef]

6. Sofia, M.J.; Bao, D.; Chang, W.; Du, J.; Nagarathnam, D.; Rachakonda, S.; Reddy, P.G.; Ross, B.S.; Wang, P.; Zhang, H.R.; et al. Discovery of a $\beta$-D-2'-deoxy-2'- $\alpha$-fluoro- $2^{\prime}-\beta-C$-methyluridine nucleotide prodrug (PSI-7977) for the treatment of hepatitis C virus. J. Med. Chem. 2010, 53, 7202-7218. [CrossRef]

7. Daignan-Fornier, B.; Pinson, B. 5-Aminoimidazole-4-carboxamide-1-beta-D-ribofuranosyl 5'-monophosphate (AICAR), a highly conserved purine intermediate with multiple effects. Metabolites 2012, 2, 292-302. [CrossRef]

8. Scudiero, O.; Nigro, E.; Monaco, M.L.; Oliviero, G.; Polito, R.; Borbone, N.; D’Errico, S.; Mayol, L.; Daniele, A.; Piccialli, G. New synthetic AICAR derivatives with enhanced AMPK and ACC activation. J. Enzyme Inhib. Med. Chem. 2015, 6366, 1-6. [CrossRef] [PubMed]

9. Merrill, G.F.; Kurth, E.J.; Hardie, D.G.; Winder, W.W. AICA riboside increases AMP-activated protein kinase, fatty acid oxidation, and glucose uptake in rat muscle. Am. J. Physiol. - Endocrinol. Metab. 1997, 273, 1107-1112. [CrossRef] [PubMed] 
10. Su, C.C.; Hsieh, K.L.; Liu, P.L.; Yeh, H.C.; Huang, S.P.; Fang, S.H.; Cheng, W.C.; Huang, K.H.; Chiu, F.Y.; Lin, I.L.; et al. AICAR induces apoptosis and inhibits migration and invasion in prostate cancer cells through an AMPK/mTOR-dependent pathway. Int. J. Mol. Sci. 2019, 20, 1647. [CrossRef] [PubMed]

11. Oliviero, G.; Amato, J.; Borbone, N.; D’Errico, S.; Piccialli, G.; Mayol, L. Synthesis of N-1 and ribose modified inosine analogues on solid support. Tetrahedron Lett. 2007, 48, 397-400. [CrossRef]

12. Oliviero, G.; Amato, J.; Borbone, N.; D’Errico, S.; Piccialli, G.; Bucci, E.; Piccialli, V.; Mayol, L. Synthesis of 4- $\mathrm{N}$-alkyl and ribose-modified AICAR analogues on solid support. Tetrahedron 2008, 64, 6475-6481. [CrossRef]

13. D'Errico, S.; Oliviero, G.; Borbone, N.; Amato, J.; Piccialli, V.; Varra, M.; Mayol, L.; Piccialli, G. Solid-phase synthesis of a new diphosphate 5-aminoimidazole-4-carboxamide riboside (AICAR) derivative and studies toward cyclic AICAR diphosphate ribose. Molecules 2011, 16, 8110-8118. [CrossRef]

14. D'Errico, S.; Oliviero, G.; Borbone, N.; Amato, J.; Piccialli, V.; Varra, M.; Mayol, L.; Piccialli, G. Synthesis of new acadesine (AICA-riboside) analogues having acyclic D-ribityl or 4-hydroxybutyl chains in place of the ribose. Molecules 2013, 18, 9420-9431. [CrossRef] [PubMed]

15. D'Errico, S.; Oliviero, G.; Borbone, N.; Piccialli, V.; Piccialli, G. Synthesis of 5-aminoimidazole-4-carboxamide riboside (AICAR) and its derivatives using inosine as starting material. Curr. Protoc. Nucleic Acid Chem. 2015, 63, 1.35.1-1.35.24. [CrossRef]

16. D’Errico, S.; Oliviero, G.; Borbone, N.; Amato, J.; D'Alonzo, D.; Piccialli, V.; Mayol, L.; Piccialli, G. A facile synthesis of $5^{\prime}$-fluoro-5'-deoxyacadesine (5'-F-AICAR): A novel non-phosphorylable AICAR analogue. Molecules 2012, 17, 13036-13044. [CrossRef]

17. Kappler, F.; Hampton, A. Approaches to isozyme-specific inhibitors. 17.1 Attachment of a selectivity-inducing substituent to a multisubstrate adduct. Implications for facilitated design of potent, isozyme-selective inhibitors. J. Med. Chem. 1990, 33, 2545-2551. [CrossRef]

18. Oliviero, G.; D’Errico, S.; Borbone, N.; Amato, J.; Piccialli, V.; Piccialli, G.; Mayol, L. Facile solid-phase synthesis of AICAR 5'-monophosphate (ZMP) and its 4- $\mathrm{N}$-alkyl derivatives. Eur. J. Org. Chem. 2010, 2010, 1517-1524. [CrossRef]

19. Ashton, T.D.; Scammells, P.J. An improved synthesis of 5'-fluoro-5'-deoxyadenosines. Bioorg. Med. Chem. Lett. 2005, 15, 3361-3363. [CrossRef]

20. Amiable, C.; Pochet, S. Unprecedented formation of $8(R), 5^{\prime}-O$-cycloribonucleosides through a triflation reaction of purine ribonucleosides. Tetrahedron 2015, 71, 2525-2529. [CrossRef]

21. Robins, M.J.; Peng, Y.; Damaraju, V.L.; Mowles, D.; Barron, G.; Tackaberry, T.; Young, J.D.; Cass, C.E. Improved syntheses of 5'-S-(2-aminoethyl)-6-N-(4-nitrobenzyl)-5'-thioadenosine (SAENTA), analogues, and fluorescent probe conjugates: Analysis of cell-surface human equilibrative nucleoside transporter 1 (hENT1) levels for prediction of the antitumor efficacy of gemcitabine. J. Med. Chem. 2010, 53, 6040-6053. [PubMed]

(C) 2019 by the authors. Licensee MDPI, Basel, Switzerland. This article is an open access article distributed under the terms and conditions of the Creative Commons Attribution (CC BY) license (http://creativecommons.org/licenses/by/4.0/). 

$N$-(2-Hydroxy-1,1-dimethylethyl)-3-methylbenzamide

\author{
Hamad H. Al Mamari * and Yousuf Al Lawati \\ Department of Chemistry, College of Science, Sultan Qaboos University, P.O. Box 36, Al Khoudh 123, Muscat, \\ Oman; ymaa91@gmail.com \\ * Correspondence: halmamari@squ.edu.om; Tel.: +968-24142471
}

Received: 14 November 2019; Accepted: 14 December 2019; Published: 19 December 2019

\begin{abstract}
The title compound, N-(2-hydroxy-1,1-dimethylethyl)-3-methylbenzamide was synthesized by reacting 3-methylbenzoyl chloride or 3-methylbenzoic acid with 2-amino-2-methyl-1-propanol. In the present report, the synthesized target compound was fully characterized by various spectroscopic methods ( ${ }^{1} \mathrm{H}$ NMR, ${ }^{13} \mathrm{C}$ NMR, IR, GC-MS), its composition confirmed by elemental analysis, and its structure determined and confirmed by X-ray analysis. The importance of this compound lies in its possession of an N,O-bidentate directing group. Such a structural motif is potentially suitable for metal-catalyzed $\mathrm{C}-\mathrm{H}$ bond functionalization reactions.
\end{abstract}

Keywords: organic synthesis; bidentate directing groups; benzamides; chelation assistance; bis-chelates; $\mathrm{C}-\mathrm{H}$ bond functionalization; $\mathrm{X}$-ray structure determination

\title{
1. Introduction
}

Functionalization of $\mathrm{C}-\mathrm{H}$ bonds $[1,2]$ has risen to be a powerful method for the transformation of inert $\mathrm{C}-\mathrm{H}$ bonds into reactive ones. Accordingly, the bond activation science enables rapid access of functionalized molecules from simple non-reactive starting materials. In turn, $\mathrm{C}-\mathrm{H}$ bond functionalization enables construction of complex molecules in an atom-economical and step-economical fashion. Site-selectivity remains a challenge in the environmentally benign strategy $[3,4]$. The problem has been tackled by development of monondentate $[5,6]$ and bidentate directing groups [7]. The Lewis-base-contained directing groups promote formation of cyclometallated complexes via chelation-assistance thus the setting stage for $\mathrm{C}-\mathrm{H}$ bond functionalization. Specifically, relative thermodynamic stability favors the formation of five-membered chelates, allowing the formation of mono five-membered chelates (1, Figure 1 ) and double-five-membered chelates (2, Figure 1$)$ by monodentate and bidentate directing groups, respectively (Figure 1) [8].

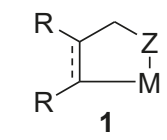

Five-membered chelate

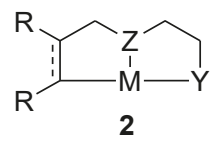

Double five-membered

chelate

Figure 1. Five-membered chelates.

Formation of the thermodynamically stable five-membered chelates necessitates a two-carbon distance between the Lewis basic atom and the position to be functionalized and the same carbon distance among the two Lewis basic atoms in bidentate directing groups. Such structural requirements have triggered the design of bidentate directing groups (3, Figure 2) that led to modular triazole directing groups (4, Figure 2). Thus, Ackermann et al. have recently disclosed a novel design of a triazole-based $\mathrm{N}, \mathrm{N}$-bidentate (TAM) directing group (5, Figure 2) that enables different $\mathrm{C}-\mathrm{H}$ bond functionalization reactions catalyzed by various transition metals $[9,10]$. 


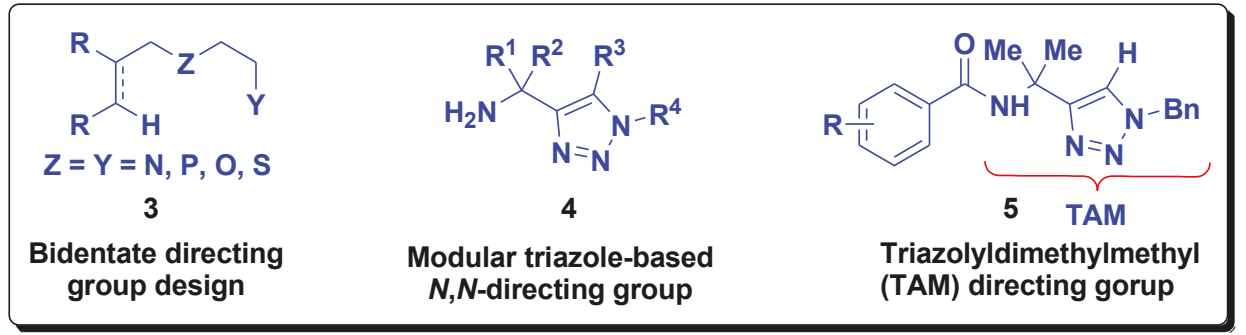

Figure 2. Development of triazole-based directing groups.

In order to mimic the modular triazole design 4 (Figure 2) and, in turn, mimic TAM group 5 (Figure 2), we developed a design of the $\mathrm{N}, \mathrm{O}$-bidentate directing groups based on 2-aminoethanol. The basis was the presence of the two-carbon distance between the $\mathrm{N}$ and $\mathrm{O}$ Lewis basic atoms thus enabling the design-based formation of the five-membered and double five-membered cyclometallated complexes. Thus, amides containing hydroxymethyl(dimethylmethyl) were envisaged (6, Scheme 1) which would have as a retrosynthetic precursor 2-amino-2-methyl-1-propanol 7 (Scheme 1).<smiles>[R]C=C([R])C(=O)NC(C)(C)CO</smiles>

6<smiles>CC(C)(N)CO</smiles>

2-amino-2-methyl-1-propanol 7

Scheme 1. Design-based 2-amino-2-methyl-1-propanol directing group.

Based on the strategic design considerations above and as part of our research program on the development of design-based bidentate directing groups, [11] we initiated synthesis of amides containing 2-amino-2-methyl-1-propanol as a potential $\mathrm{N}, \mathrm{O}$-bidentate directing group. The aim would ultimately be to test such amides in metal-catalyzed $\mathrm{C}-\mathrm{H}$ bond functionalization reactions. Based on the possession of $\mathrm{N}$ and $\mathrm{O}$ Lewis basic atoms strategically separated by two carbons in the amides, it was projected that amides containing 2-amino-2-methyl-1-propanol (6, Scheme 2) could potentially allow formation of the corresponding double-five-membered chelate (8, Scheme 2$)$ which sets the stage for the ultimate $\mathrm{C}-\mathrm{H}$ bond cleavage leading to functionalized amide 9 (Scheme 2). Therefore, amides containing 2-amino-2-methyl-1-propanol could potentially function as a bidentate directing group in $\mathrm{C}-\mathrm{H}$ bond functionalization reactions.<smiles>[R]C=C([R])C(=O)NC(C)(C)CO</smiles>

6

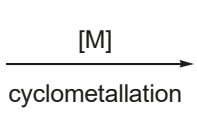

cyclometallation

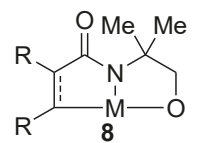<smiles>C=CC1CCCC1</smiles><smiles>[R]C(=O)C([R])=C(C)NC(C)(C)CO</smiles>

\section{Double five-membered} chelate

Scheme 2. Potential use of amides containing 2-amino-2-methyl-1-propanol in C-H bond functionalization.

In the present communication, a synthesis of the title compound, $N$-(2-hydroxy-1,1-dimethylethyl)3-methylbenzamide is reported. The importance of the compound lies in its potential reactivity as a $\mathrm{N}, \mathrm{O}$-bidentate directing group in metal-catalyzed $\mathrm{C}-\mathrm{H}$ bond functionalization reactions. The literature reports studies involving a similar synthesis which suggests the possible formation of the title compound as a possible reaction intermediate or byproduct $[12,13]$. However, the compound was not isolated, its formation was not confirmed, and neither its characterization by spectroscopic methods nor structure determination have been reported. Li et al. [12] reported Pd-catalyzed C-H 
fluorination of arenes using oxazolines as removable directing groups. The reported synthesis could have involved the title compound as a possible reaction intermediate or a byproduct. However, no spectroscopic characterization was reported. In addition, a similar oxazoline synthesis was reported by Swenton et al. [13]. The reported synthesis could have involved the title compound as a possible reaction intermediate or byproduct. However, yet again, the title compound was not isolated and, thus, spectroscopic information or characterization have not been reported.

We wish to report herein a standard synthesis of the title compound, N-(2-hydroxy-1,1dimethylethyl)-3-methylbenzamide (11), from the corresponding benzoyl chloride or benzoic acid. The compound was full characterized by various spectroscopic methods, elemental analysis, and its structure was determined and confirmed by X-ray analysis (Please see the Supporting Information for spectra and other Supporting Materials).

\section{Results and Discussion}

Toward investigating 2-amino-2-methyl-1-propanol as a potential directing group in metal-catalyzed $\mathrm{C}-\mathrm{H}$ functionalization, 3-methylbenzamide containing the requisite amino alcohol indicated above, the title compound, $N$-(2-hydroxy-1,1-dimethylethyl)-3-methylbenzamide (11), was synthesized. Thus, 3-methylbenzolyl chloride (10, Scheme 3) was reacted with 2-amino-2-methyl-1propanol $(7$, Scheme 3$)$ under standard amide formation reaction conditions to give the corresponding amide in isolated $62 \%$ yield.<smiles>Cc1cccc(C(=O)Cl)c1</smiles>

10<smiles>CC(C)(N)CO</smiles>

7

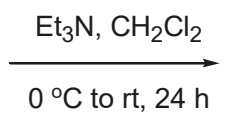

$0^{\circ} \mathrm{C}$ to rt, $24 \mathrm{~h}$<smiles>Cc1cccc(C(=O)NC(C)(C)CO)c1</smiles>

11: $62 \%$

Scheme 3. Synthesis of N-(2-hydroxy-1,1-dimethylethyl)-3-methylbenzamide from 3-methylbenzoyl chloride.

For comparison purposes, the target compound (11) was also obtained using a carboxylic acid-amine coupling method. Thus the 3-methylbenzoic acid (12, Scheme 4) was treated with the coupling agent; DCC (dicyclohexylcarbodiimide) and 2-amino-2-methyl-1-propanol (7) in the presence of DMAP (4- $N, N$-dimethylaminopyridine) to give the desired title compound, $N$-(2-hydroxy-1,1-dimethylethyl)-3-methylbenzamide (11), in 11\% yield.<smiles>Cc1cccc(C(=O)O)c1</smiles>

12<smiles>CC(C)(N)CO</smiles>

7

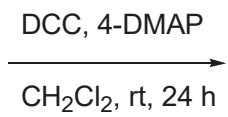

$\mathrm{CH}_{2} \mathrm{Cl}_{2}, \mathrm{rt}, 24 \mathrm{~h}$<smiles>Cc1cccc(C(=O)NC(C)(C)CO)c1</smiles>

11: $11 \%$

Scheme 4. Synthesis of N-(2-hydroxy-1,1-dimethylethyl)-3-methylbenzamide from 3-methylbenzoic acid.

The product was characterized by various spectroscopic methods; ${ }^{1} \mathrm{H}$ NMR, ${ }^{13} \mathrm{C}$ NMR, IR, GC-MS, and its elemental composition was confirmed by elemental analysis. In addition, the crystal structure of the compound was determined and confirmed by X-ray analysis (Figure 3). CCDC 1965367 contains the supplementary crystallographic data for this paper. These data can be obtained free of charge from The Cambridge Crystallographic Data Centre via http://www.ccdc.cam.ac.uk/conts/retrieving.html (or from the CCDC, 12 Union Road, Cambridge CB2 1EZ, UK; Fax: +44 1223 336033; E-mail: deposit@ccdc.cam.ac.uk). 


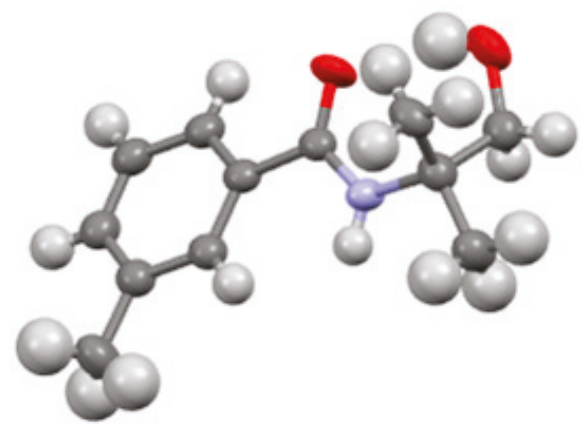

Figure 3. Molecular structure of the title compound. Thermal ellipsoids correspond to $50 \%$ probability.

Formation of amides was recently reported by Machetti et al. [14] to proceed from methyl esters and amines. For comparison purposes, the title amide compound (11) was attempted to be prepared using the reported ester amidation reaction. Thus, methyl 3-methylbenzoate was treated with an equimolar amount of 2-amino-2-methyl-1-propanol (7) at $60{ }^{\circ} \mathrm{C}$ for $24 \mathrm{~h}$. The reaction resulted in formation of only a very small amount of the desired amide product as detected by thin-layer chromatography (TLC) and ${ }^{1} \mathrm{H}$ NMR.

\section{Materials and Methods}

\subsection{General Methods}

All chemicals, reagents, and solvents were purchased from chemical companies (Sigma-Aldrich Chemie GmbH, Taufkirchen, Germany) and were used as received without prior purification. Reactions that required dry conditions were performed in an inert atmosphere with Ar gas. Syringes and needles for the transfer of reagents were oven dried and cooled in a desiccator over silica gel before use. The reaction's progress was monitored by thin-layer chromatography (TLC) on glass plates pre-coated with Merck silica gel. Thhe TLC plates were examined under a UV lamplight (UVGL-58 Handheld 254/365 nm). Büchi-USA rotary evaporators were used to evaporate solvents using appropriate temperatures. Flash column chromatography was performed using silica gel (Kieselgel) (70-230) mesh as an adsorbent. The purified products were characterized using analyses $\mathrm{NMR}\left({ }^{1} \mathrm{H} \mathrm{NMR},{ }^{13} \mathrm{C}\right.$ NMR$)$, IR, mass spectra, and melting points. Melting points were recorded on a GallenKamp-MPd350.bm2.5 melting point apparatus (Gallenkamp, Kent, UK). Attenuated total-reflectance IR spectra were recorded on pure samples on Agilent Technologies Cary 630 FTIR (Agilent, Santa Clara, CA, USA). ${ }^{1} \mathrm{H}$ NMR spectra were recorded in $\mathrm{CDCl}_{3}$ on JEOL ECX-400 spectrometers (JEOL Ltd., Tokyo, Japan). ${ }^{1} \mathrm{H}$ NMR chemical shifts $(\delta)$ were assigned in parts per million $(\mathrm{ppm})$ downfield using an internal standard trimethyl silane (TMS) and were referenced to $\mathrm{CDCl}_{3}, \delta=7.24$. Abbreviations s, $\mathrm{d}, \mathrm{t}$, q, quin, sept, and $\mathrm{m}$ refer to singlet, doublet, triplet, quartet, quintet, septet, and multiplet, respectively. Chemical shifts in ${ }^{13} \mathrm{C}$ spectra $(175 \mathrm{MHz})$ were quoted in ppm and referenced to the central line of the $\mathrm{CDCl}_{3}$ triplet, $\delta \mathrm{C}$ 77.0. Coupling constants $(J)$ were recorded in hertz $(\mathrm{Hz})$. The GC-MS spectra were obtained using an Agilent mass spectrometer (Agilent, Santa Clara, CA, USA). Elemental analysis was performed using an EuroEA Elemental Analyzer (configuration CHN (EuroVector Instruments \& Software, Milano, Italy) with a calibration type of K-factor. Single-crystal X-ray structure determinations were performed at room temperature on a Stoe IPS II diffractometer using monochromatic $\mathrm{Mo}-\mathrm{K}_{\alpha}$ radiation $(\lambda=$ $0.71073 \AA$ ). A multi-scan absorption correction was applied. The data reduction, including an empirical absorption correction using spherical harmonics, was implemented in LANA. The crystal structures were solved by direct methods using the online version of WinGX and then refined by full-matrix least-squares (SHELXL2014) on $\mathrm{F}^{2}$. The non-hydrogen atoms were refined anisotropically. All of the hydrogen atoms were positioned geometrically in idealized positions and refined with the riding 
model approximation with $\mathrm{Uiso}(\mathrm{H})=1.2$ or $1.5 \mathrm{Ueq}(\mathrm{C})$. The molecular graphics program MERCURY from the Cambridge Structural Database (CSD) package was used.

\subsection{Synthesis of N-(2-Hydroxy-1,1-dimethylethyl)-3-methylbenzamide (11)}

3-Methylbenzoyl chloride (10) $(1.30 \mathrm{~mL}, 9.86 \mathrm{mmol})$ was added dropwise under an atmosphere of $\mathrm{N}_{2}$ into a cold $\left(0{ }^{\circ} \mathrm{C}\right.$ ice-water bath) solution of 2-amino-2-methylpropan-1-ol (7) $(0.50 \mathrm{~mL}, 5.2 \mathrm{mmol})$, in $\mathrm{CH}_{2} \mathrm{Cl}_{2}(20 \mathrm{~mL})$. Triethylamine $\left(\mathrm{Et}_{3} \mathrm{~N}(1.40 \mathrm{~mL}, 10.0 \mathrm{mmol})\right.$ was then added to the $0^{\circ} \mathrm{C}$ mixture under $\mathrm{N}_{2}$. The mixture was stirred for $1 \mathrm{~h}$ at $0{ }^{\circ} \mathrm{C}$, allowed to warm up to room temperature, and then stirred for an additional $23 \mathrm{~h}$. To the reaction mixture, an aqueous saturated $\mathrm{NaHCO}_{3}$ solution $(20 \mathrm{~mL})$ was added. The mixture was extracted with $\mathrm{CH}_{2} \mathrm{Cl}_{2}(3 \times 20 \mathrm{~mL})$. The combined organic extracts were dried over anhydrous $\mathrm{MgSO}_{4}$ and filtered. The solvents were evaporated under reduced pressure, and the crude residue was purified by flash chromatography $\left(\mathrm{SiO}_{2}\right)$ using hexane: $\mathrm{Et}_{2} \mathrm{O}(5: 1)$, giving the title compound $11(0.66 \mathrm{~g}, 62 \%)$ as white crystals after recrystallization from $\mathrm{CH}_{2} \mathrm{Cl}_{2}$ :hexane; $\mathrm{R}_{\mathrm{f}}=0.12$ (Pet. Ether/EtOAc, 1:1) and $\mathrm{mp}=81-83^{\circ} \mathrm{C} .{ }^{1} \mathrm{H}$ NMR $\left(400 \mathrm{MHz}, \mathrm{CDCl}_{3}\right): \delta 7.52(\mathrm{~s}, 1 \mathrm{H}), 7.49(\mathrm{~d}, J=2.3 \mathrm{~Hz}$, $1 \mathrm{H}), 7.48(\mathrm{~d}, J=1.9 \mathrm{~Hz}, 1 \mathrm{H}), 7.28 \mathrm{~Hz}(\mathrm{dd}, J=3.8,3.3 \mathrm{~Hz}, 1 \mathrm{H}), 7.25(\mathrm{~s}, 1 \mathrm{H}), 6.24(\mathrm{~s}, 1 \mathrm{H}), 3.66(\mathrm{~s}, 2 \mathrm{H})$, 2.37 (s, $3 \mathrm{H}), 1.39$ (s, $6 \mathrm{H}) .{ }^{13} \mathrm{C}$ NMR $\left(176 \mathrm{MHz}, \mathrm{CDCl}_{3}\right): \delta 168.8,138.6,134.8,132.5,128.6,127.7,123.9$, 70.8, 56.5, 24.8, 24.4. IR (film): $v \max / \mathrm{cm}^{-1}: 3340,3198,2924,1627,1535,1548,1481$. Elemental analysis calculated: C (69.54), H (8.27), N (6.76), found (average of two runs): C (69.33), H (8.17), N (6.53).

\subsection{Refinement Details of the X-ray Structure}

Single-crystal $\mathrm{X}$-ray structure determinations were performed at room temperature on a Stoe IPS II diffractometer using monochromatic Mo- $\mathrm{K}_{\alpha}$ radiation $(\lambda=0.71073 \AA)$. A multiscan absorption correction was applied. The data reduction, including an empirical absorption correction using spherical harmonics, implemented in LANA. The crystal structures were solved by direct methods using the online version of WinGX [15] and then refined by full-matrix least-squares (SHELXL2014) on $\mathrm{F}^{2}[16,17]$. The nonhydrogen atoms were refined anisotropically. All of the hydrogen atoms were positioned geometrically in idealized positions and refined with the riding model approximation, with Uiso $(\mathrm{H})=1.2$ or $1.5 \mathrm{Ueq}(\mathrm{C})$. The molecular graphics the program MERCURY from the CSD package was used [18]. The structure was solved by direct methods. The data used for the refinement are up to a resolution of 2-theta $=37.7$ degrees as the intensity of the data dropped rapidly after this point. The flack parameter $(x=-0.901)$ was refined by full-matrix least squares (i.e., using the TWIN/BASF commands in the SHELXL.ins file) [19]. Hydrogen atoms were included in calculated positions.

\section{Conclusions}

The title compound, $\mathrm{N}$-(2-hydroxy-1,1-dimethylethyl)-3-methylbenzamide, was synthesized from either the acid chloride (62\%, Scheme 3) or the carboxylic acid (11\%, Scheme 4$)$ with the former being the more efficient method. The compound was characterized by various spectroscopic methods $\left({ }^{1} \mathrm{H}\right.$ NMR, ${ }^{13} \mathrm{C}$ NMR, IR, GC-MS), its elemental composition was determined by elemental analysis measurements, and its crystal structure was determined and confirmed by $\mathrm{X}$-ray analysis. With amides containing the requisite 2-amino-2-methyl-1-propanol now in hand, work is currently underway to investigate their potential in functioning as $\mathrm{N}, \mathrm{O}$-bidentate directing groups in metal-catalyzed $\mathrm{C}-\mathrm{H}$ bond functionalization reactions.

Supplementary Materials: The following are available online, Figure S1: GC-MS of the tile compound, Figure S2: IR of the title compound, Figure S3: ${ }^{1} \mathrm{H}$ NMR of the title compound, Figure S4: ${ }^{13} \mathrm{C}$ NMR of the title compound, Figure S5: Elemental analysis of the title compound.

Author Contributions: Y.A.L. carried out all experimental work under the supervision of H.H.A.M. All authors have read and agreed to the published version of the manuscript.

Funding: This research work was funded by a Sultan Qaboos University Internal Grant (IG/SCI/CHEM/15/02). 
Acknowledgments: The support of Sultan Qaboos University is gratefully acknowledged. The authors would like to thank Nawal Al Rasbi at the Department of Chemistry, College of Science, Sultan Qaboos University, for X-ray measurements.

Conflicts of Interest: Authors declare no conflict of interest.

\section{References}

1. Shilov, A.E.; Shul'pin, G.B. Activation of C-H bonds by metal complexes. Chem. Rev. 1997, 97, $2879-2932$. [CrossRef] [PubMed]

2. Ryabov, A. Mechanisms of intramolecular activation of carbon-hydrogen bonds in transition-metal complexes. Chem. Rev. 1990, 90, 403-424. [CrossRef]

3. Dick, A.R.; Sanford, M.S. Transition metal catalyzed oxidative functionalization of carbon-hydrogen bonds. Tetrahdedron 2006, 2439-2463. [CrossRef]

4. Li, J.; De Sarkar, S.; Ackermann, L. Meta- and para-selective C-H functionalization by C-H cctivation. Top. Organomet. Chem. 2016, 55, 217-257. [CrossRef]

5. Sato, T.; Yoshida, T.; Al Mamari, H.H.; Ilies, L.; Nakamura, E. Manganese-catalyzed directed methylation of $\mathrm{C}\left(\mathrm{sp}^{2}\right)-\mathrm{H}$ bonds at $25^{\circ} \mathrm{C}$ with high catalytic turnover. Org. Lett. 2017, 19, 5458-5461. [CrossRef] [PubMed]

6. Sambiagio, C.; Schönbauer, D.; Blieck, R.; Dao-Huy, T.; Pototschnio, G.; Schaaf, P.; Wiesinger, T.; Zia, M.F.; Wencel-Delord, J.; Besset, T.; et al. A Comprehensive review of directing groups applied in metal-catalyzed C-H functionalization chemistry. Chem. Soc. Rev. 2018, 47, 6603-6743. [CrossRef] [PubMed]

7. Rouquet, G.; Chatani, N. Catalytic functionalization of $\mathrm{C}\left(\mathrm{sp}^{2}\right)-\mathrm{H}$ and $\mathrm{C}\left(\mathrm{sp}^{3}\right)-\mathrm{H}$ bonds by using bidentate directing groups. Angew. Chem. Int. Ed. 2013, 52, 11726-11743. [CrossRef]

8. Omae, I. Intramolecular five-membered ring compounds and their applications. Coord. Chem. Rev. 2004, 248, 995-1023. [CrossRef]

9. Al Mamari, H.H.; Diers, E.; Ackermann, L. Triazole-assisted ruthenium-catalyzed C-H arylation of aromatic amides. Chem. Eur. J. 2014, 20, 9739-9743. [CrossRef] [PubMed]

10. Gu, Q.; Al Mamari, H.H.; Graczyk, K.; Diers, E.; Ackermann, L. Iron-catalyzed C(sp $\left.{ }^{2}\right)-\mathrm{H}$ and C(sp $\left.{ }^{3}\right)$-H arylation by triazole assistance. Angew. Chem. Int. Ed. 2014, 53, 3868-3871, Angew. Chem. 2014, 126, 3949-3952. [CrossRef] [PubMed]

11. Al Mamari, H.H.; Al Awaimri, N.; Al Lawati, Y. N-Benzo[c][1,2,5]thiazol-4-yl-3 -trifluoromethylbenzamide. Molbank 2019, 2019, M1075. [CrossRef]

12. Guiterrez, D.A.; Lee, W.-C.C.; Shen, Y.; Li, J.J. Palladium-catalyzed electrophilic C-H fluorination of arenes usingoxazoline as a removable directing group. Tetrahedron Lett. 2016, 57, 5372-5376. [CrossRef]

13. Swenton, J.S.; Platz, M.; Venham, L.D. Rates of hydrogen atom abstraction from benzyltrimethylsilanes by bromine and tert-butoxy radical. The Question of the stability of the $\alpha$-(trimethylsilyl)benzyl radical. J. Org. Chem. 1988, 53, 2764-2768. [CrossRef]

14. Machetti, F.; Bucelli, I.; Indiani, G.; Kappe, C.O.; Guarna, A. Parallel synthesis of an amide library based on the 6,8-dioxa-3-azabicyclo [3.2.1] octane scaffold by direct aminolysis of methyl esters. J. Comb. Chem. 2007, 9, 454-461. [CrossRef] [PubMed]

15. Farrugia, L.J. WinGX suite for small-molecule single-crystal crystallography. J. Appl. Cryst. 1999, 32, 837-838. [CrossRef]

16. Sheldrick, G.M. SADABS: A Program for Absorption Correction with the Siemens SMART System; University of Göttingen: Göttingen, Germany, 1996.

17. Sheldrick, G.M. SHELXS-97: A Program for Solution and Refinement of Crystal Structures; University of Göttingen: Göttingen, Germany, 1997.

18. Macrae, C.F.; Edgington, P.R.; McCabe, P.; Pidcock, E.; Shields, G.P.; Taylor, R.; Towler, M.; van de Streek, J. Mercury: Visulaization and analysis of crystal structures. J. Appl. Cryst. 2006, 39, 453-457. [CrossRef]

19. Hooft, R.W.W.; Straver, L.H.; Spek, A.L. Using the t-distribution to improve the absolute structure assignment with likelihood calculations. J. Appl. Cryst. 2010, 43, 665-668. [CrossRef]

(C) 2019 by the authors. Licensee MDPI, Basel, Switzerland. This article is an open access article distributed under the terms and conditions of the Creative Commons Attribution (CC BY) license (http://creativecommons.org/licenses/by/4.0/). 


\title{
$N^{\prime}$-Acetyl-3-methyl-1,6-diphenyl-1H- pyrazolo $[3,4-b]$ pyridine-4-carbohydrazide
}

\author{
Júlio C. A. V. Soares and Luiza R. S. Dias * \\ Laboratório de Química Medicinal-LQMed, Faculdade de Farmácia, Universidade Federal Fluminense, \\ Rua Mário Viana, 523, Santa Rosa, Niterói, RJ 24241-000, Brazil; juliovanelis@id.uff.br \\ * Correspondence: lrsdias@id.uff.br; Tel.: +55-21-2629-9578
}

Received: 7 December 2019; Accepted: 29 December 2019; Published: 7 January 2020

\begin{abstract}
Synthesis of $N^{\prime}$-acetyl-3-methyl-1,6-diphenyl-1H-pyrazolo[3,4-b]pyridine-4-carbohydrazide from the phenyl acetates of 3-acetyl-5-(3-methyl-1,6-diphenyl-1 $H$-pyrazolo[3,4-b]pyridine-4-yl)-2,3dihydro-1,3,4-oxadiazol-2-yl in alkaline medium and its characterization by spectroscopic methods.
\end{abstract}

Keywords: $N^{\prime}$-acetylhydrazide; 3-acetyl-2,3-dihydro-1,3,4-oxadiazole; $1 H$-pyrazolo[3,4-b]pyridine; heterocycle

\section{Introduction}

$N^{\prime}$-acetyl and $N^{\prime}$-benzoyl hydrazide derivatives containing a heterocycle nucleus have shown antimicrobial and anti-TB activities [1,2]. These compounds are usually synthesized from carbohydrazide derivatives by an addition-elimination reaction with acyl chlorides [3,4]. $N^{\prime}$-acetyl and $N^{\prime}$-benzoyl hydrazides are also used for the synthesis of 1,3,4-oxadiazole compounds, which can be found in the structure of molecules with reported bioactivity to several targets and related to a wide range of diseases [5-7].

On the other hand, $N^{\prime}$-acetyl derivatives are often found as the metabolites of the hydrazide group from drugs, such as isoniazid [8,9]. However, the administration of acetylisoniazid leads to diacetylhydrazine $\left(\mathrm{CH}_{3} \mathrm{CONHNHCOCH}{ }_{3}\right)$ as the primary metabolite excreted in which the acyl $\mathrm{C}-\mathrm{N}$ bond from the pyridine-carboxamide is more susceptible to lysis than is the acyl $\mathrm{C}-\mathrm{N}$ bond from the alkylamide group [8].

Herein, we describe an unexpected approach to obtain $N^{\prime}$-acetylhydrazides from hydrolysis of the 3-acetyl-2,3-dihydro-1,3,4-oxadiazole derivatives of 1,6-diphenyl-1H-pyrazolo[3,4-b]pyridine nucleus and their characterization by spectroscopic methods.

\section{Results and Discussion}

Hydrolysis methods using sodium acetate are widely used in aromatic acetate deprotection reactions, whereas the ordinarily, stable, aliphatic amides require stronger hydrolysis conditions than the ester motif [10]. In this sense, it could be expected that the mild alkaline and/or no heating conditions could provide the selective hydrolysis of the $O$-acetyl group from the phenyl acetates of 3-acetyl-5-(3-methyl-1,6-diphenyl-1H-pyrazolo[3,4-b]pyridin-4-yl)-2,3-dihydro-1,3,4-oxadiazol-2-yl.

In fact, if the treatment of compounds 1a-1c with a $4.2 \mathrm{M}$ aqueous $\mathrm{NaOAc}$ solution in $n$-butanol at room temperature did not give any reaction, the exposure to a methanolic/aqueous $\mathrm{NaHCO}_{3}$ solution at room temperature resulted as being effective in the $\mathrm{O}$-acetyl group cleavage [11]. Conversely, both the treatment with a $4.2 \mathrm{M}$ aqueous $\mathrm{NaOAc}$ solution in $n$-butanol under conventional heating or microwave irradiation (Methods $\mathrm{A}$ and $\mathrm{B}$, respectively) and with a methanolic $\mathrm{KOH}$ (3 equiv.) solution (Method C) yielded the $N^{\prime}$-acetylhydrazide derivative 2 (Scheme 1), as a consequence of the 2,3-dihydro-1,3,4-oxadiazole rings' degradation [12]. The opening of the 2,3-dihydro-1,3,4-oxadiazoles was previously reported under acidic conditions only [13,14]. 


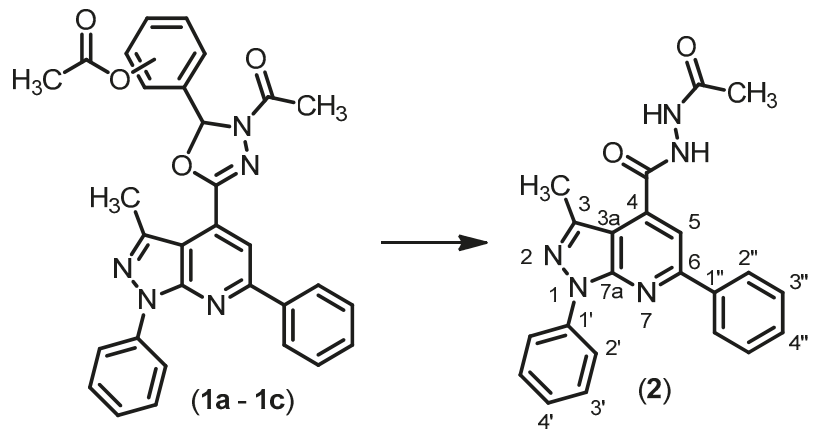

Scheme 1. $N^{\prime}$-acetyl-3-methyl-1,6-diphenyl-1H-pyrazolo[3,4-b]pyridine-4-carbohydrazide (2) from 2,3-dihydro-1,3,4-oxadiazoles derivatives: $\mathbf{1 a}(4-\mathrm{OAc}), \mathbf{1 b}$ (3-OAc-4-OCH 3$), \mathbf{1 c}(3,4-d i-O A c)$. Methods: (A) NaOAc, $n$-BuOH, reflux; (B) NaOAc, $n-\mathrm{BuOH}$, M.W.; (C) $\mathrm{KOH}, \mathrm{MeOH}$, r.t.

The structure of compound 2 was confirmed by spectroscopic methods (Infrared (IR), nuclear magnetic resonance (NMR) and high-resolution mass spectrometry (HRMS), Figures S1-S4). In the protonic nuclear magnetic resonance $\left({ }^{1} \mathrm{H}-\mathrm{NMR}\right)$ spectrum of compound 2 , the signals of the protons from 1,6-dipheny-1H-pyrazolo[3,4- $b$ ]pyridine nucleus were observed at $\delta 2.64 \mathrm{ppm}(\mathrm{s}, 3 \mathrm{H})$ for the methyl group at the C-3 position; $\delta 7.36(\mathrm{dd}, 1 \mathrm{H}), \delta 7.55-7.62 \mathrm{ppm}(\mathrm{m}, 5 \mathrm{H}), \delta 8.25(\mathrm{~d}, 2 \mathrm{H})$ and $\delta$ $8.33 \mathrm{ppm}(\mathrm{d}, 2 \mathrm{H})$ for phenyl groups in the $\mathrm{N}-1$ and $\mathrm{C}-6$ positions; and $\delta 7.90 \mathrm{ppm}(\mathrm{s}, 1 \mathrm{H})$ for the aromatic proton at the C-5 position [11]. Additionally, one signal at $\delta 2.00 \mathrm{ppm}(\mathrm{s}, 3 \mathrm{H})$ corresponding to the methyl group from acetyl-hydrazine moiety and two signals at $\delta 10.03 \mathrm{ppm}(\mathrm{s}, 1 \mathrm{H})$ and $\delta 10.56$ ppm $(\mathrm{s}, 1 \mathrm{H})$ corresponding to hydrazide protons (RCONHNHCOR'), were observed. The protons of the 2,3-dihydro-1,3,4-oxadiazole ring (singlet at $\delta 7.1 \mathrm{ppm}$ ) and of the substituted phenyl groups present in the compounds $\mathbf{1 a}-\mathbf{1 c}$ were not observed [11]. In the same way, the signals corresponding to the carbons of these moieties in the APT spectrum were also not detected. The splitting of signals observed in the NMR spectra of compound 2 could be related to the presence of conformers around the $\mathrm{N}-\mathrm{CO}$ bond, as reported for similar compounds $[15,16]$. However, it needs further analysis. In the HRMS spectrum of compound 2, the presence of the molecular ion peak at $m / z=386.1611\left([\mathrm{M}+\mathrm{H}]^{+}\right)$ supported the proposed structure.

In conclusion, we have described the unusual synthesis of $N^{\prime}$-acetylhydrazide 2 from derivatives 1a-1c. These results show the lability of the 2,3-dihydro-1,3,4-oxadiazole ring in alkaline medium. This fact could be exploited for stability studies related to drugs containing this moiety.

\section{Materials and Methods}

All commercial products (Sigma-Aldrich Brasil Ltda., São Paulo, Brazil) and solvents (Vetec Química Fina Ltda., Duque de Caxias, Brazil) were used without further purification. Compounds 1a-1c were synthesized according to methods previously described in the literature [11,17]. The reactions under microwave irradiation were conducted in a domestic microwave device (Brastemp ${ }^{\circledR}$, São Paulo, Brazil, model BMX35, 900W, $30 \mathrm{~L}$ ) using a flat bottom balloon connected to an L-shaped adapter joint glassware. All reactions were monitored by thin-layer chromatography (TLC) analysis from reaction aliquots and were performed on Merck 60 F254 aluminum in combination with ultraviolet (UV) detection (254 and $365 \mathrm{~nm}$ ). Melting points were determined in a capillary Thomas Hoover PC03296 apparatus, and the values are uncorrected. IR spectra were measured on a Varian 660-IR, FT-IR spectrophotometer (Agilent Technologies, Santa Clara, CA, USA), by using the KBr pellet method. NMR spectra were recorded on a Varian VNMRS spectrophotometer (Agilent Technologies, ${ }^{1} \mathrm{H}-\mathrm{NMR}$ at $500 \mathrm{MHz}$ and ${ }^{13} \mathrm{C}-\mathrm{NMR}$ at $\left.125 \mathrm{MHz}\right)$.

Proton chemical shifts $(\delta)$ are reported in parts per million (ppm) relative to tetramethylsilane (TMS), with the solvent employed as the internal standard (dimethyl sulfoxide DMSO- $d_{6}$ ). The structure 
identification was aided by an Attached Proton Test (APT) spectrum. Mass spectra were recorded on AmaZon SL-Electrospray (ESI) ion trap Bruker spectrometer, and HRMS (positive ESI-Q-TOF) analyses were performed on an Impact HD mass spectrometer (Bruker Corporation, Billerica, MA, USA).

N'-Acetyl-3-methyl-1,6-diphenyl-1H-pyrazolo[3,4-b]pyridine-4-carbohydrazide (2)

Method A

A suspension of 2-(acetoxyphenyl)-2,3-dihydro-1,3,4-oxadiazole (1b, $0.12 \mathrm{~g}, 0.21 \mathrm{mmol}$ ) in $n$-butanol $(1 \mathrm{~mL})$ was stirred at reflux temperature until complete solubilization. Then, NaOAc ( $0.5 \mathrm{~mL}$ of a $4.2 \mathrm{M}$ aqueous solution, $2.1 \mathrm{mmol}$ ) was added, and the mixture was stirred for additional $3 \mathrm{~h}$ at reflux temperature. The reaction was monitored by TLC using ethyl acetate in hexane 3:4 $v / v$ as the eluent. At the end of the reaction, the solution was cooled at room temperature and poured into water $(10 \mathrm{~mL})$. The mixture was extracted with ethyl acetate $(3 \times 10 \mathrm{~mL})$. The combined organic phases were washed with brine, dried over anhydrous sodium sulfate, and the solvent was removed under vacuum. Recrystallization from methanol gave pure 2 ( $0.052 \mathrm{~g}, 64 \%$ yield).

\section{Method B}

A suspension of 2-(acetoxyphenyl)-2,3-dihydro-1,3,4-oxadiazole (1b or 1c, $0.12 \mathrm{~g}, 0.21 \mathrm{mmol}$ ) in $n$-butanol $(1 \mathrm{~mL})$ was prepared. $\mathrm{NaOAc}(0.5 \mathrm{~mL}$ of a $4.2 \mathrm{M}$ aqueous solution, $2.1 \mathrm{mmol})$ was added to the mixture and homogenized manually. The mixture was put under microwave irradiation $(900 \mathrm{~W})$ at regular intervals of $30 \mathrm{~s}$. The monitoring of the reaction, work-up and purification steps were identical to Method A. The pure compound $2(0.079 \mathrm{~g}$, 97\% yield) was obtained after $3 \mathrm{~min}$ or $10 \mathrm{~min}$ of reaction from $1 \mathbf{b}$ or $1 \mathrm{c}$, respectively.

Method C

$\mathrm{KOH}(0.016 \mathrm{~g}, 0.28 \mathrm{mmol})$ was added to a suspension of 2-(acetoxyphenyl)-2,3-dihydro-1,3,4oxadiazole (1a, $0.050 \mathrm{~g}, 0.090 \mathrm{mmol})$ in methanol $(10 \mathrm{~mL})$. The mixture reaction was stirred for $1 \mathrm{~h}$ at room temperature, and its progress monitored like previously described. At the end of the reaction, the $\mathrm{pH}$ was adjusted to 7.0 (neutral) with a $1 \mathrm{M}$ aqueous solution of $\mathrm{HCl}(20 \mathrm{~mL})$. The mixture was poured into water $(10 \mathrm{~mL})$ and extracted with ethyl acetate $(3 \times 10 \mathrm{~mL})$. The combined organic phases were dried over anhydrous sodium sulfate and the solvent was removed under vacuum. Recrystallization from methanol gave pure 2 ( $0.032 \mathrm{~g} ; 87 \%$ yield).

\section{Structural Characterization}

White solid. m.p. $=268-270{ }^{\circ} \mathrm{C} \cdot \mathrm{R}_{\mathrm{f}}=0.51$ (ethyl acetate-hexane, 3:4 v/v). IR $\left(v-\mathrm{cm}^{-1}\right): 3197$ $(\mathrm{N}-\mathrm{H}) ; 3040\left(\mathrm{C}_{\mathrm{sp} 2}-\mathrm{H}\right) ; 2922\left(\mathrm{C}_{\mathrm{sp} 3}-\mathrm{H}\right) ; 1611(\mathrm{C}=\mathrm{O}) .{ }^{1} \mathrm{H}-\mathrm{NMR}\left(\mathrm{DMSO}-d_{6} / \mathrm{TMS}\right): \delta(\mathrm{ppm})=2.00(\mathrm{~s}, 3 \mathrm{H}$, $\left.\mathrm{H}_{3} \mathrm{C}(\mathrm{CO}) \mathrm{N}-\right) ; 2.64$ (s, 3H, H-8); $7.36\left(\mathrm{t}, 1 \mathrm{H}, J=7.5 \mathrm{~Hz}, \mathrm{H}-4^{\prime}\right) ; 7.55-7.62$ (m, 5H, H-3'/H-3"/H-4"); 7.90 (s, 1H, H-5); 8.25 (d, 2H, J = 7.5 Hz, H-2"); 8.33 (d, 2H, $\left.J=8.0 \mathrm{~Hz}, \mathrm{H}-2^{\prime}\right) ; 10.03$ (s, 1H, N-H); 10.56 (s, $1 \mathrm{H}$, $\mathrm{N}-\mathrm{H}) .{ }^{13} \mathrm{C}$ NMR-APT (DMSO-d 6 /TMS): (ppm) = 14.0 (C-8); $20.2\left(\mathrm{H}_{3} \mathrm{CC}=\mathrm{O}\right) ; 111.4$ (C-3a); 112.7 (C-5); 120.3 (C-2'); 125.4 (C-4'); 127.0 (C-1"); 127.1 (C-2"); 128.7 (C-4"); 128.9 (C-3'); 129.7 (C-3"); 137.7 (C-4); 138.8 (C-1'); 142.2 (C-3); 150.9 (C-7a); 156.0 (C-6); 164.2 (-HNHNC=O); $168.1\left(\mathrm{H}_{3} \mathrm{CC}=\mathrm{O}\right)$. HRESI-MS $m / z$ 386.1611, $\left([\mathrm{M}+\mathrm{H}]+\right.$ calcd. for $\left.\mathrm{C}_{22} \mathrm{H}_{19} \mathrm{~N}_{5} \mathrm{O}_{2} 386.1611\right)$.

Supplementary Materials: The following are available online, Compound 2 spectra: IR (Figure S1); ${ }^{1} \mathrm{H}-\mathrm{NMR}$ (Figure S2); APT (Figure S3); HRMS (Figure S4).

Author Contributions: J.C.A.V.S.-synthesis, spectroscopic analysis, writing the manuscript; L.R.S.D.conceptualization, supervision, data analysis, writing the manuscript. The authors read and approved the final manuscript. All authors have read and agreed to the published version of the manuscript.

Funding: This study was supported in part by Brazil's funding agencies, CAPES (Coordination of Improvement of Higher Education Personnel) and FAPERJ (Foundation for Research Support of the State of Rio de Janeiro).

Acknowledgments: We thank CAPES-BR for the fellowship of J.C.A.V.S. 
Conflicts of Interest: The authors declare no conflict of interest.

\section{References}

1. Azab, M.; El-Hashash, M.; Morsy, J.; Mahmoud, N. Design, synthesis and anticancer activity of novel 2,3and 2,4-disubstituted quinazoline and quinazolinone derivatives. Heterocycles 2016, 92, 316. [CrossRef]

2. Joshi, S.D.; Dixit, S.R.; Kulkarni, V.H.; Lherbet, C.; Nadagouda, M.N.; Aminabhavi, T.M. Synthesis, biological evaluation and in silico molecular modeling of pyrrolyl benzohydrazide derivatives as enoyl ACP reductase inhibitors. Eur. J. Med. Chem. 2017, 126, 286-297. [CrossRef] [PubMed]

3. Pouliot, M.F.; Angers, L.; Hamel, J.D.; Paquin, J.F. Synthesis of 1,3,4-oxadiazoles from 1,2-diacylhydrazines using [Et 2NSF 2]BF 4 as a practical cyclodehydration agent. Org. Biomol. Chem. 2012, 10, 988-993. [CrossRef] [PubMed]

4. Abbas, A.; Ali, B.; Khan, K.M.; Iqbal, J.; Ur Rahman, S.; Zaib, S.; Perveen, S. Synthesis and in vitro urease inhibitory activity of benzohydrazide derivatives, in silico and kinetic studies. Bioorg. Chem. 2019, 82, 163-177. [CrossRef] [PubMed]

5. Boström, J.; Hogner, A.; Llinàs, A.; Wellner, E.; Plowright, A.T. Oxadiazoles in medicinal chemistry. J. Med. Chem. 2012, 55, 1817-1830. [CrossRef] [PubMed]

6. Khalilullah, H.; Ahsan, M.J.; Hedaitullah, M.; Khan, S.; Ahmed, B. 1,3,4-oxadiazole: A biologically active scaffold. Mini Rev. Med. Chem. 2012, 12, 789-801. [CrossRef] [PubMed]

7. Pitasse-Santos, P.; Sueth-Santiago, V.; Lima, M.E.F. 1,2,4- and 1,3,4-oxadiazoles as scaffolds in the development of antiparasitic agents. J. Braz. Chem. Soc. 2018, 29, 435-456. [CrossRef]

8. Preziosi, P. Isoniazid: Metabolic aspects and toxicological correlates. Curr. Drug Metab. 2007, 8, 839-851. [CrossRef] [PubMed]

9. Semina, I.I.; Balashov, V.P.; Kurmysheva, T.V.; Tarasova, R.I.; Shilovskaya, E.V.; Voskresenskaya, O.V.; Baichurina, A.Z.; Al'Myasheva, M.I. Synthesis and pharmacological activity of (2-chloroethoxy-4'dimethylaminophenyl)phosphorylacetic acid hydrazide (CAPAH) and its metabolite ( $N$-acetyl derivative). Pharm. Chem. J. 2013, 47, 28-30. [CrossRef]

10. Wang, G.B.; Wang, L.F.; Li, C.Z.; Sun, J.; Zhou, G.M.; Yang, D.C. A facile and efficient method for the selective deacylation of $\mathrm{N}$-arylacetamides and 2-chloro-Narylacetamides catalyzed by SOCl2. Res. Chem. Intermed. 2012, 38, 77-89. [CrossRef]

11. Soares, J.C.A.V. Planejamento, Síntese e Avaliação da Atividade Antichagásica de Novos Derivados 1H-Pirazolo[3,4-b]piridina. Master's Thesis, Universidade Federal Fluminense, Niterói, Brazil, 2018.

12. Narender, T.; Reddy, K.P.; Madhur, G. NaOAc-mediated selective deprotection of aromatic acetates and its application in the synthesis of natural products. Synth. Commun. 2009, 39, 1949-1956. [CrossRef]

13. Zhou, Y.; Wang, B.; Di, F.; Xiong, L.; Yang, N.; Li, Y.; Li, Z. Synthesis and biological activities of 2,3-dihydro-1,3,4-oxadiazole compounds and its derivatives as potential activator of ryanodine receptors. Bioorg. Med. Chem. Lett. 2014, 24, 2295-2299. [CrossRef] [PubMed]

14. Omar, R.H.; El-Fattah, B.A. Synthesis of certain pyridyl 1,3,4-oxadiazoles of biological interest and study of the cleavage of certain substituted oxadiazole rings with primary amines [abstract]. Egypt J. Pharm. Sci. 1985, 24, 49-56.

15. Hamzi, I.; Fray, M.; Abidi, R.; Barhoumi-Slimi, T. Synthesis, characterization and conformational study of new $\alpha, \beta$-unsaturated acylhydrazones based on calix [4]arene backbone. J. Mol. Struct. 2019, 1185, 78-84. [CrossRef] 
16. Litvinov, I.A.; Lodochnikova, O.A.; Bukharov, S.V.; Nugumanova, G.N.; Tagasheva, R.G.; Karamov, F.A. Molecular and crystal structure of indole and camfora with sterically hindered phenol fragments. J. Struct. Chem. 2019, 60, 308-314. [CrossRef]

17. Lee, L.; Robb, L.M.; Lee, M.; Davis, R.; Mackay, H.; Chavda, S.; Babu, B.; O’Brien, E.L.; Risinger, A.L.; Mooberry, S.L.; et al. Design, synthesis, and biological evaluations of 2,5-diaryl-2,3-dihydro-1,3,4-oxadiazoline analogs of combretastatin-A4. J. Med. Chem. 2010, 53, 325-334. [CrossRef] [PubMed]

(C) 2020 by the authors. Licensee MDPI, Basel, Switzerland. This article is an open access article distributed under the terms and conditions of the Creative Commons Attribution (CC BY) license (http://creativecommons.org/licenses/by/4.0/). 



\title{
Communication \\ Unexpected Formation of Oxetanes during the Synthesis of Dodeco-6,7-diuloses
}

\author{
Marius Bayer, Cäcilia Maichle-Mössmer and Thomas Ziegler* \\ Institute of Organic Chemistry, University of Tuebingen, Auf der Morgenstelle 18, 72076 Tuebingen, Germany; \\ marius.bayer@uni-tuebingen.de (M.B.); Caecilia.Maichle-Moessmer@uni-tuebingen.de (C.M.-M.) \\ * Correspondence: thomas.ziegler@uni-tuebingen.de
}

Received: 11 December 2019; Accepted: 9 January 2020; Published: 14 January 2020

\begin{abstract}
During the synthesis of symmetrical dodeco-6,7-diuloses that are potential candidates for inhibition of glycosidases, an unanticipated epoxide-oxetane rearrangement was observed. A bicyclic sugar consisting of a glycal moiety and an anomeric esterified furanose was oxidized under epoxidation conditions ( $m \mathrm{CPBA} / \mathrm{KF}$ ). The isolation of the pure epoxide was not possible since a rapid reversible conversion accompanied by the migration of the ester group took place and resulted in the formation of an unusual oxetane-bridged disaccharide scaffold. X-ray diffractometric structure elucidation and the suggested mechanism of the rearrangement are provided.
\end{abstract}

Keywords: oxetane; epoxide; rearrangement; carbohydrate; C-glycosylation; spiro-oxetane; ester group migration

\section{Introduction}

Oxetane rings attached directly to a carbohydrate unit rarely occur in literature, due to steric reasons [1]. The most common representatives are 3,5-anhydrofuranose derivatives, which are formed by nucleophilic [2,3] or additive [4] intramolecular ring closure reactions. In addition to the furanoid 3,5-linked oxetanes, there also exists a limited number of 1,2-fused or anomeric spiro-oxetanes having a pyranoid constitution. These highly strained scaffolds are prepared photochemically [5-7] or via template-directing $C$-glycosylations $[8,9]$. In synthesis, sugar oxetanes are used as versatile precursors since the rigid conformation and steric repulsion of the bridge favor high stereoselectivities [10]. Furthermore, the detection of antimicrobial properties has brought these structures closer to the focus of current research [4]. In this communication, we introduce a new method for the generation of anomerically bridged oxetanes whose formation was initiated by an unexpected rearrangement of an epoxide assisted by an adjacent ester group.

\section{Results and Discussion}

Starting from the known compounds $\mathbf{1}$ [11] and 2 [12] a base-induced coupling of two anomeric centers analogous to Shiozaki's protocol [13] was performed (Scheme 1). Contrary to Shiozaki's procedure, which involved the use of toxic stannylated glycals, we could employ 1-phenylsulfinyl glycals since it is known that they are easily lithiated in a similar fashion with one equivalent of phenyllithium [14]. Sulfoxide 1 was treated with phenyllithium at $-78^{\circ} \mathrm{C}$ followed by quenching with manno-lactone 2 after 5 minutes. The observance of this reaction time is mandatory since a longer reaction time results in the irreversible formation of the protonated glycal species in increasing amounts leading to by-products. The coupled disaccharide 3 was isolated as an anomeric mixture $(\alpha / \beta$ ratio $1: 5)$ in $80 \%$ yield. Next, the anomeric hydroxyl group was masked in order to avoid its coordinating effect on the envisaged stereoselective epoxidation. For this purpose, we decided to choose the ester protecting groups acetyl and benzoyl. Thus, the fully protected disaccharides $4 \mathbf{a}$ and $\mathbf{4 b}$ were obtained 
after the acylation step in $96 \%$ and $68 \%$ yield, respectively. In both cases solely the $\beta$-anomers were obtained which was proven by H,H-NOESY NMR spectroscopy (see Supplementary Materials).
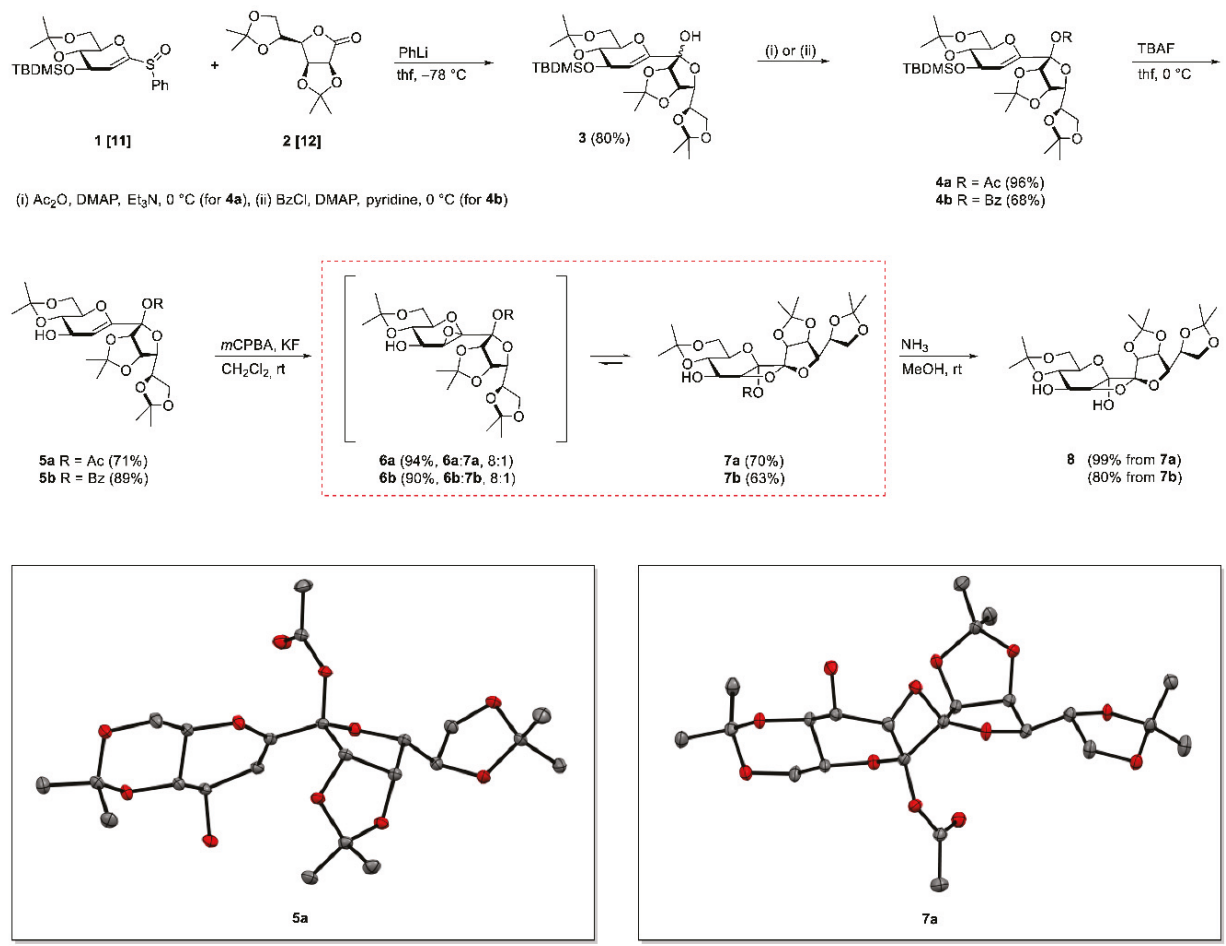

Scheme 1. Synthesis of the isopropylidene-protected oxetane-bridged disaccharide 8 and X-ray structures of $5 \mathbf{a}$ and $7 \mathbf{a}$.

Furthermore, the configuration could be confirmed by growing crystals of 5a suitable for X-ray diffraction by recrystallization of the latter from $n$-hexane and ethyl acetate. Compound 5 a was obtained through desilylation of $\mathbf{4 a}$ with tetra- $n$-butylammonium fluoride (Scheme 1 ). The moderate yield of $71 \%$ can be explained by detectable partial cleavage of the acetyl group in alkaline milieu during desilylation. The benzoyl protecting group was significantly more stable under the same conditions resulting in a yield of $89 \%$ for the conversion of $4 \mathbf{b}$ to $5 \mathbf{b}$. In our efforts to synthesize symmetrical dodeco-6,7-diuloses both sugar moieties need to be manno-configured. Therefore, the next step was to stereoselectively convert the glycal entity into a mannose derivative. Conventional methods for the implementation of stereoselective dihydroxylation on similar allyl alcohol systems use substrate-directing reagents such as molybdenum catalysts [15], vanadyl acetylacetonate (VO(acac) $\left.)_{2}\right)[16,17]$ or meta-chloroperbenzoic acid ( $m$ CPBA) $[17,18]$ for epoxidation. Subsequent epoxide opening leads to the desired diol derivatives. When these methodologies were applied to disaccharides $\mathbf{5 a}$ and $\mathbf{5 b}$ the best results were achieved using the Camps reagent $(m \mathrm{CPBA} / \mathrm{KF})[18,19]$. The addition of potassium fluoride reduces the solubility of $m \mathrm{CPBA}$ and $m \mathrm{CBA}$ and thus, inhibiting nucleophilic epoxide opening by the acids. However, we could not isolate the pure epoxides $6 \mathbf{a}$ and $\mathbf{6 b}$ for a rapid rearrangement of the latter to oxetane species $7 \mathbf{a}$ and $7 \mathbf{b}$ occurred. Upon early quenching of the epoxidation reaction, only 8:1 mixtures of epoxide and oxetane could be isolated in yields of $94 \%$ for $\mathbf{6 a}$ and $90 \%$ for $\mathbf{6 b}$, respectively. In order to enable the complete conversion of the epoxide to the oxetane derivatives the reaction times were extended and $7 \mathbf{a}$ and $7 \mathbf{b}$ could be obtained neatly in $70 \%$ and $63 \%$ yields, respectively. Crystals of compound 7 a suitable for X-ray crystallography could be obtained by overlaying a saturated solution of $7 \mathbf{a}$ in methylene 
chloride with $n$-heptane and slowly evaporating the methylene chloride. Thus, the oxetane-bridged disaccharide structure of $7 \mathrm{a}$ with two anomeric $\alpha$-configurations could be unambiguously verified (Scheme 1). For the formation of oxetanes 7 we propose a mechanism deduced from the X-ray data in which ester group migration from position 7 to 6 occurs simultaneously with $O$-heterocyclic ring extension of the oxirane ring to the less strained oxetane ring (Figure 1). The rearrangement process can also be visualized by ${ }^{1} \mathrm{H}-\mathrm{NMR}$ spectroscopy since the $\mathrm{H}-5$ signal of oxetane $7 \mathbf{a}(4.96 \mathrm{ppm}, 4.6 \mathrm{~Hz})$ is significantly shifted to lower field compared to the characteristic doublet of H-5 in epoxide 6 a (3.66 ppm, 2.4 Hz) (Figure 1). To some extent, this rearrangement resembles the Ferrier rearrangement of acetylated glycals. Alternatively, a stepwise mechanism via the intermediate formation of carbenium ions can also be envisaged.

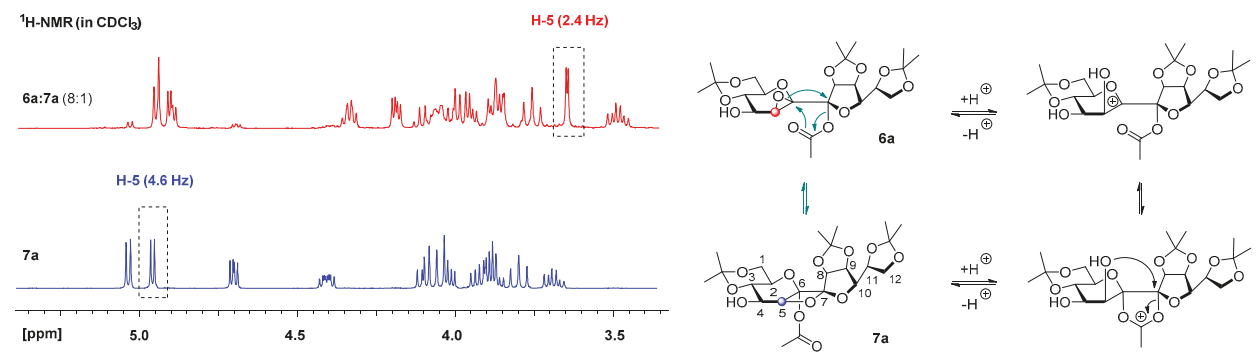

Figure 1. Proposed mechanisms for the rearrangement from epoxide $6 \mathbf{a}$ to oxetane $7 \mathbf{a}$ and their ${ }^{1} \mathrm{H}-\mathrm{NMR}$ spectra in $\mathrm{CDCl}_{3}$ to illustrating the reaction progress.

It must also be mentioned that the rearrangement appeared to be reversible for in attempts to recrystallize $7 \mathbf{a}$ from boiling $n$-hexane the precipitation of an amorphous substance which turned out to be epoxide 6a was observed. Studies are ongoing to evaluate both the effect of the temperature and of the solvent on the equilibrium ratio between compounds $6 \mathbf{a}$ and $7 \mathbf{a}$. After removal of the ester protecting groups of $7 \mathbf{a}$ and $7 \mathbf{b}$ with ammonia in methanol, oxetane 8 was obtained from both compounds in $99 \%$ and $80 \%$ yield respectively (Scheme 1). Oxetanes 8 did not recede to the corresponding epoxides according to TLC monitoring. Consequently, it was proven that $7 \mathbf{b}$ is also present as an oxetane-fused disaccharide.

\section{Materials and Methods}

All reactions were performed under an atmosphere of nitrogen using solvents dried by standard procedures. Reaction progress was monitored by TLC on Polygram SIL G/UV 254 silica gel plates from Macherey and Nagel, Germany. Detection of spots was affected by carbonizing with sulfuric acid (5\% in EtOH), staining by spraying the plates with an alkaline aqueous solution of potassium permanganate or by inspection of the TLC plates under UV light $(254 \mathrm{~nm})$. Preparative flash chromatography was performed on silica gel $(0.032-0.063 \mathrm{~mm})$ from Macherey-Nagel, using plastic cartridges from Götec. The flowrate was regulated by a Sykam S1122 solvent delivery system. Nuclear magnetic resonance (NMR) spectra were recorded with a Bruker Avance 400 spectrometer and calibrated for the solvent signal $\left({ }^{1} \mathrm{H}: \mathrm{CDCl}_{3}: \delta=7.26 \mathrm{ppm}\right.$; acetone- $d_{6}: \delta=2.05 \mathrm{ppm}$; DMSO- $d_{6}: \delta=2.50 \mathrm{ppm} ;{ }^{13} \mathrm{C}: \mathrm{CDCl}_{3}$ : $\delta=77.16 \mathrm{ppm}$; acetone- $\left.\mathrm{d}_{6}: \delta=29.92 \mathrm{ppm} ; \mathrm{DMSO}-\mathrm{d}_{6}: \delta=39.52 \mathrm{ppm}\right)$. All NMR-assignments were proven by 2D-experiments to be correct. ESI-TOF-HRM spectrometry was performed on a Bruker MAXIS 4G spectrometer. Elemental analyses were obtained from a HEKA tech Euro EA 3000 apparatus. Optical rotations were determined with a Perkin-Elmer Polarimeter 341 in a $10 \mathrm{~cm}$ cuvette at $20^{\circ} \mathrm{C}$ with a wavelength of $589 \mathrm{~nm}$ (Na-lamp). Melting points were measured with a Büchi Melting Point M-560 apparatus. 
2,6-Anhydro-5-deoxy-4-O-(tert-butyldimethylsilyl)-1,3:8,9:11,12-tri-O-isopropylidene-D-arabino-L-gulododeco-7-ulo-6-enitol (3)

To a suspension of 1 ( $2.62 \mathrm{~g}, 6.18 \mathrm{mmol})$ and grounded molecular sieve $(3 \AA, 30 \mathrm{mg})$ in THF $(40 \mathrm{~mL})$ was added phenyllithium $\left(1.9 \mathrm{M}\right.$ in $\left.\mathrm{Bu}_{2} \mathrm{O}, 3.57 \mathrm{~mL}, 6.79 \mathrm{mmol}\right)$ at $-78{ }^{\circ} \mathrm{C}$ over a period of $15 \mathrm{~min}$. After $5 \mathrm{~min}$ a further solution containing $2(1.75 \mathrm{~g}, 6.79 \mathrm{mmol})$ in THF $(20 \mathrm{~mL})$ was added dropwise over a period of $30 \mathrm{~min}$. Subsequently, the reaction mixture was stirred for $2 \mathrm{~h}$ at the same temperature before the cooling bath was removed. The reaction was quenched by addition of sat. aq. $\mathrm{NH}_{4} \mathrm{Cl}$-solution $(60 \mathrm{~mL})$ at ambient temperature and the molecular sieve was filtered off. The organic layer was separated, the aqueous layer was extracted with $\mathrm{CH}_{2} \mathrm{Cl}_{2}(3 \times 20 \mathrm{~mL})$ and the combined organic layers were dried with $\mathrm{Na}_{2} \mathrm{SO}_{4}$. Removing of the solvent followed by column chromatography (methylene chloride/ethyl acetate 5:1) furnished 3 (2.77 mg, $4.97 \mathrm{mmol}, 80 \%$, anomeric mixture $\alpha: \beta, 1: 5)$ as a colorless crystalline solid. $R_{\mathrm{f}}=0.22-0.46$ (methylene chloride/ethyl acetate 5:1).

$3 \beta^{*}$ (major anomer): ${ }^{1} \mathrm{H}-\mathrm{NMR}\left(400 \mathrm{MHz}, \mathrm{CDCl}_{3}\right): \delta(\mathrm{ppm})=5.04\left(\mathrm{~d}, \mathrm{~J}_{5,4}=2.2 \mathrm{~Hz}, 1 \mathrm{H}, \mathrm{H}-5\right), 4.82(\mathrm{dd}$, $\left.J_{9,8}=5.7 \mathrm{~Hz}, J_{9,10}=3.5 \mathrm{~Hz}, 1 \mathrm{H}, \mathrm{H}-9\right), 4.53$ (d, $\left.J_{8,9}=5.9 \mathrm{~Hz}, 1 \mathrm{H}, \mathrm{H}-8\right), 4.38-4.44$ (m, 1H, H-11), 4.33-4.35 (m, 1H, H-4), 4.15 (dd, $\left.J_{10,11}=7.2 \mathrm{~Hz}, J_{10,9}=3.5 \mathrm{~Hz}, 1 \mathrm{H}, \mathrm{H}-10\right), 4.07-4.11$ (m, 1H, H-12a), 4.03 (dd, $J=8.7 \mathrm{~Hz}, J=4.9 \mathrm{~Hz}, 1 \mathrm{H}, \mathrm{H}-12 \mathrm{~b}), 3.86-3.95$ (m, 2H, H-1a, H-1b), 3.71-3.76 (m, 2H, H-2, H-3), 2.77 (s, 1H, OH), 1.50, 1.44, 1.42, 1.40, 1.38, $1.31\left(6 \mathrm{~s}, 18 \mathrm{H}, \mathrm{C}\left(\mathrm{CH}_{3}\right)_{2}\right), 0.87\left(\mathrm{~s}, 9 \mathrm{H}, \mathrm{SiC}\left(\mathrm{CH}_{3}\right)_{3}\right), 0.07,0.06(2 \mathrm{~s}$, $\left.6 \mathrm{H}, \mathrm{SiCH}_{3}\right) .{ }^{13} \mathrm{C}-\mathrm{NMR}\left(101 \mathrm{MHz}, \mathrm{CDCl}_{3}\right): \delta(\mathrm{ppm})=150.4(\mathrm{C}-6), 113.3,109.1\left(\mathrm{C}_{\left(\mathrm{CH}_{3}\right)}\right), 104.3(\mathrm{C}-5)$, 103.4 (C-7), $99.4\left(\mathrm{C}\left(\mathrm{CH}_{3}\right)_{2}\right), 86.7$ (C-8), 80.0 (C-9), 79.4 (C-10), 73.2 (C-11), 72.9 (C-3), 70.2 (C-2), 68.2 (C-4), 66.7 (C-12), $61.7(\mathrm{C}-1), 28.9,26.8,25.8\left(\mathrm{C}\left(\mathrm{CH}_{3}\right)_{2}\right), 25.7\left(\mathrm{SiC}\left(\mathrm{CH}_{3}\right)_{3}\right), 25.4,25.0,19.1\left(\mathrm{C}\left(\mathrm{CH}_{3}\right)_{2}\right), 18.1$ $\left(\mathrm{SiC}\left(\mathrm{CH}_{3}\right)_{3}\right),-4.4,-4.8\left(\mathrm{SiCH}_{3}\right)$.

$3 \alpha^{*}$ (minor anomer): ${ }^{1} \mathrm{H}-\mathrm{NMR}\left(400 \mathrm{MHz}, \mathrm{CDCl}_{3}\right): \delta(\mathrm{ppm})=5.07\left(\mathrm{~d}, J_{5,4}=2.1 \mathrm{~Hz}, 1 \mathrm{H}, \mathrm{H}-5\right), 4.79(\mathrm{dd}$, $\left.J_{9,8}=6.0 \mathrm{~Hz}, J_{9,10}=3.7 \mathrm{~Hz}, 1 \mathrm{H}, \mathrm{H}-9\right), 4.62\left(\mathrm{~d}, J_{8,9}=6.0 \mathrm{~Hz}, 1 \mathrm{H}, \mathrm{H}-8\right), 4.34-4.35$ (m, 2H, H-4, H-11), 4.10-4.11 (m, 1H, H-12a), 4.01-4.02 (m, 1H, H-12b), 3.85-3.88 (m, 2H, H-1a, H-1b, 3.76-3.80 (m, 3H, $\mathrm{H}-2, \mathrm{H}-3, \mathrm{H}-10), 2.77$ (s, 1H, OH), 1.57, 1.49, 1.42, 1.40, $1.36\left(5 \mathrm{~s}, 18 \mathrm{H}, \mathrm{C}\left(\mathrm{CH}_{3}\right)_{2}\right), 0.88\left(\mathrm{~s}, 9 \mathrm{H}, \mathrm{SiC}\left(\mathrm{CH}_{3}\right)_{3}\right)$, $0.08,0.07\left(2 \mathrm{~s}, 6 \mathrm{H}, \mathrm{SiCH}_{3}\right) .{ }^{13} \mathrm{C}-\mathrm{NMR}\left(101 \mathrm{MHz}, \mathrm{CDCl}_{3}\right): \delta(\mathrm{ppm})=150.8(\mathrm{C}-6), 113.6,109.3\left(\mathrm{C}\left(\mathrm{CH}_{3}\right)_{2}\right)$, 103.1 (C-5), $100.6(\mathrm{C}-7), 99.6\left(\mathrm{C}\left(\mathrm{CH}_{3}\right)_{2}\right), 80.7$ (C-8), 80.0 (C-9), $78.6(\mathrm{C}-10), 73.2(\mathrm{C}-11), 72.8(\mathrm{C}-3), 70.3$ (C-2), $67.8(\mathrm{C}-4), 67.2(\mathrm{C}-12), 61.7(\mathrm{C}-1), 28.9,26.9,25.9\left(\mathrm{C}\left(\mathrm{CH}_{3}\right)_{2}\right), 25.8\left(\mathrm{SiC}\left(\mathrm{CH}_{3}\right)_{3}\right), 25.2,24.6,19.0$ $\left(\mathrm{C}\left(\mathrm{CH}_{3}\right)_{2}\right), 18.2\left(\mathrm{SiC}\left(\mathrm{CH}_{3}\right)_{3}\right),-4.4,-4.8\left(\mathrm{SiCH}_{3}\right)$. HRESIMS m/z 581.27570 (calcd for $\mathrm{C}_{27} \mathrm{H}_{46} \mathrm{O}_{10} \mathrm{SiNa}_{\text {, }}$ 581.27524); anal. C 58.37, $\mathrm{H} 8.21$, calcd for $\mathrm{C}_{27} \mathrm{H}_{46} \mathrm{O}_{10} \mathrm{Si}, \mathrm{C} 58.04, \mathrm{H} 8.39$. *Anomers $3 \beta$ and $3 \alpha$ could be interchanged

\section{2,6-Anhydro-5-deoxy-7-O-acetyl-4-O-(tert-butyldimethylsilyl)-1,3:8,9:11,12-tri-O-isopropylidene- $\beta$-D-} manno-D-lyxo-dodeco-6-enitol (4a)

A solution of $3(300 \mathrm{mg}, 0.537 \mathrm{mmol})$ and 4-dimethylaminopyridine (13 $\mathrm{mg}, 0.107 \mathrm{mmol})$ in triethylamine $(7 \mathrm{~mL})$ was treated with acetic anhydride $(508 \mu \mathrm{L}, 5.37 \mathrm{mmol})$ at $0{ }^{\circ} \mathrm{C}$. After stirring for $12 \mathrm{~h}$ at ambient temperature until TLC indicated complete transformation of the starting material, the reaction mixture was diluted with ethyl acetate $(20 \mathrm{~mL})$. The organic phase was washed with $1 \mathrm{~N}$ hydrochloric acid $(3 \times 10 \mathrm{~mL})$, sat. aq. $\mathrm{NH}_{4} \mathrm{Cl}$-solution $(1 \times 10 \mathrm{~mL})$ and brine $(1 \times 10 \mathrm{~mL})$. The solution was dried with $\mathrm{Na}_{2} \mathrm{SO}_{4}$, the solvent was removed and the crude product was purified by column chromatography (petroleum ether/ethyl acetate 5:1) to afford 4 a (309 $\mathrm{mg}, 0.515 \mathrm{mmol}, 96 \%$ ) as a colorless crystalline solid. $R_{\mathrm{f}}=0.82$ (methylene chloride/ethyl acetate $\left.5: 1\right) .[\alpha]_{\mathrm{D}}^{20}=+64.3(\mathrm{c}=1.0$, $\left.\mathrm{CHCl}_{3}\right)$. M.p. $52{ }^{\circ} \mathrm{C}$ (n-hexane). ${ }^{1} \mathrm{H}-\mathrm{NMR}\left(400 \mathrm{MHz}, \mathrm{CDCl}_{3}\right): \delta(\mathrm{ppm})=4.99\left(\mathrm{~d}, J_{5,4}=2.2 \mathrm{~Hz}, 1 \mathrm{H}, \mathrm{H}-5\right)$, $4.86\left(\mathrm{dd}, J_{9,8}=5.6 \mathrm{~Hz}, J_{9,10}=3.4 \mathrm{~Hz}, 1 \mathrm{H}, \mathrm{H}-9\right), 4.69\left(\mathrm{~d}, J_{8,9}=5.6 \mathrm{~Hz}, 1 \mathrm{H}, \mathrm{H}-8\right), 4.42(\mathrm{ddd}, J=8.3 \mathrm{~Hz}$, $J=5.9 \mathrm{~Hz}, J=3.9 \mathrm{~Hz}, 1 \mathrm{H}, \mathrm{H}-11), 4.35\left(\mathrm{dd}, J_{4,3}=6.7 \mathrm{~Hz}, J_{4,5}=2.1 \mathrm{~Hz}, 1 \mathrm{H}, \mathrm{H}-4\right), 4.09-4.15(\mathrm{~m}, 1 \mathrm{H}$, H-12a), 3.99-4.07 (m, 2H, H-10, H-12b), 3.80-3.89 (m, 2H, H-1aH-1b), 3.61-3.73 (m, 2H, H-2, H-3), 2.01 $\left(\mathrm{s}, 3 \mathrm{H}, \mathrm{COCH}_{3}\right), 1.48,1.47,1.45,1.37,1.37,1.33\left(6 \mathrm{~s}, 18 \mathrm{H}, \mathrm{C}\left(\mathrm{CH}_{3}\right)_{2}\right), 0.83\left(\mathrm{~s}, 9 \mathrm{H}, \mathrm{SiC}\left(\mathrm{CH}_{3}\right)_{3}\right), 0.03,0.03$

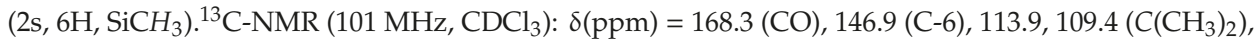

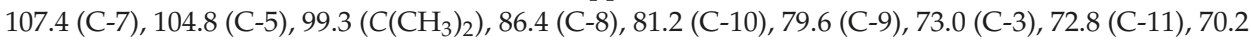


(C-2), $\left.68.2(\mathrm{C}-4), 67.1(\mathrm{C}-12), 61.7(\mathrm{C}-1), 28.9,27.0,25.8\left(\mathrm{C}\left(\mathrm{CH}_{3}\right)_{2}\right), 25.6\left(\mathrm{SiC}\left(\mathrm{CH}_{3}\right)_{3}\right), 25.1,25.1\left(\mathrm{C}^{(} \mathrm{CH}_{3}\right)_{2}\right)$,

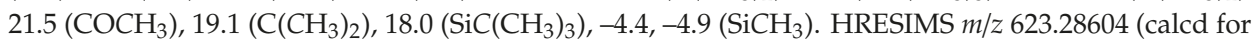
$\mathrm{C}_{29} \mathrm{H}_{48} \mathrm{O}_{11} \mathrm{SiNa}$, 623.28581); anal. C 58.10, H 8.21, calcd for $\mathrm{C}_{29} \mathrm{H}_{48} \mathrm{O}_{11} \mathrm{Si}, \mathrm{C}$ 57.98, H 8.05.

2,6-Anhydro-5-deoxy-7-O-benzoyl-4-O-(tert-butyldimethylsilyl)-1,3:8,9:11,12-tri-O-isopropylidene- $\beta$-Dmanno-D-lyxo-dodeco-6-enitol (4b)

A solution of 3 ( $930 \mathrm{mg}, 1.67 \mathrm{mmol}$ ) and DMAP (41 mg, $0.333 \mathrm{mmol})$ in pyridine $(15 \mathrm{~mL})$ was treated with benzoyl chloride $(1.92 \mathrm{~mL}, 16.7 \mathrm{mmol})$ at $0{ }^{\circ} \mathrm{C}$. After stirring for $48 \mathrm{~h}$ at ambient temperature TLC indicated complete transformation of the starting material and the reaction mixture was diluted with ethyl acetate $(60 \mathrm{~mL})$. The organic layer was washed with $1 \mathrm{~N}$ hydrochloric acid $(3 \times 30 \mathrm{~mL})$, sat. aq. $\mathrm{NaHCO}_{3}$-solution $(3 \times 20 \mathrm{~mL})$ and brine $(1 \times 20 \mathrm{~mL})$. The solution was dried with $\mathrm{Na}_{2} \mathrm{SO}_{4}$, the solvent was removed and the crude product was purified by column chromatography (toluene/ethyl acetate, gradient: $100: 1-20: 1)$ to afford $4 \mathbf{b}(749 \mathrm{mg}, 1.13 \mathrm{mmol}, 68 \%)$ as a colorless crystalline solid. $R_{\mathrm{f}}=0.66$ (toluene/ethyl acetate $\left.4: 1\right) . \quad[\alpha]_{\mathrm{D}}^{20}=+57.1\left(\mathrm{c}=1.0, \mathrm{CHCl}_{3}\right)$. M.p. $58{ }^{\circ} \mathrm{C} .{ }^{1} \mathrm{H}-\mathrm{NMR}$ $\left(400 \mathrm{MHz}, \mathrm{CDCl}_{3}\right): \delta(\mathrm{ppm})=7.90-8.02(\mathrm{~m}, 2 \mathrm{H}, \mathrm{Ph}), 7.52-7.62(\mathrm{~m}, 1 \mathrm{H}, \mathrm{Ph}), 7.39-7.48(\mathrm{~m}, 2 \mathrm{H}, \mathrm{Ph}), 5.11(\mathrm{~d}$, $\left.J_{5,4}=2.3 \mathrm{~Hz}, 1 \mathrm{H}, \mathrm{H}-5\right), 4.90-5.01(\mathrm{~m}, 2 \mathrm{H}, \mathrm{H}-8, \mathrm{H}-9), 4.47$ (ddd, $J=8.2 \mathrm{~Hz}, J=6.0 \mathrm{~Hz}, J_{11,12 \mathrm{~b}}=4.0 \mathrm{~Hz}$, $1 \mathrm{H}, \mathrm{H}-11), 4.41\left(\mathrm{dd}, J_{4,3}=6.7 \mathrm{~Hz}, J_{4,5}=2.2 \mathrm{~Hz}, 1 \mathrm{H}, \mathrm{H}-4\right), 4.08-4.17$ (m, 2H, H-10, H-12a), 4.05 (dd, $\left.J_{12 \mathrm{~b}, 12 \mathrm{a}}=9.1 \mathrm{~Hz}, J_{12 \mathrm{~b}, 11}=4.0 \mathrm{~Hz}, 1 \mathrm{H}, \mathrm{H}-12 \mathrm{~b}\right), 3.66-3.84$ (m, 4H, H-1a, H-1b, H-2, H-3), 1.52, 1.48, 1.42, $1.38,1.37\left(5 \mathrm{~s}, 18 \mathrm{H}, \mathrm{C}\left(\mathrm{CH}_{3}\right)_{2}\right), 0.86\left(\mathrm{~s}, 9 \mathrm{H}, \mathrm{SiC}\left(\mathrm{CH}_{3}\right)_{3}\right), 0.06,0.06\left(2 \mathrm{~s}, 6 \mathrm{H}, \mathrm{SiCH}_{3}\right) .{ }^{13} \mathrm{C}-\mathrm{NMR}(101 \mathrm{MHz}$, $\left.\mathrm{CDCl}_{3}\right): \delta(\mathrm{ppm})=164.0(\mathrm{CO}), 147.3(\mathrm{C}-6), 133.4,130.2,129.9,128.5(\mathrm{Ph}), 114.2,109.6\left(\mathrm{C}_{\left.\left(\mathrm{CH}_{3}\right)_{2}\right), 108.2}\right.$ (C-7), 105.1 (C-5), $99.5\left(\mathrm{C}^{\left(\mathrm{CH}_{3}\right)}\right.$ ) $), 86.7$ (C-8), 81.8 (C-10), 80.0 (C-9), 73.3 (C-3), 73.0 (C-11), 70.4 (C-2), 68.5 (C-4), $\left.67.3(\mathrm{C}-12), 61.8(\mathrm{C}-1), 29.1,27.1,26.0\left(\mathrm{C}\left(\mathrm{CH}_{3}\right)_{2}\right), 25.8\left(\mathrm{SiC}\left(\mathrm{CH}_{3}\right)_{3}\right), 25.4,25.3,19.3\left(\mathrm{C}_{(\mathrm{CH}}\right)_{2}\right)$, $18.2\left(\mathrm{SiC}\left(\mathrm{CH}_{3}\right)_{3}\right),-4.2,-4.7\left(\mathrm{SiCH}_{3}\right)$. HRESIMS $m / z 685.30154$ (calcd for $\mathrm{C}_{34} \mathrm{H}_{50} \mathrm{O}_{11} \mathrm{SiNa}, 685.30146$ ); anal. C 61.26, $\mathrm{H}$ 8.02, calcd for $\mathrm{C}_{34} \mathrm{H}_{50} \mathrm{O}_{11} \mathrm{Si}, \mathrm{C} 61.61, \mathrm{H}$ 7.60.

\section{General Procedure A for Desilylation of $\mathbf{4 a}$ and $\mathbf{4 b}$}

Tetra- $n$-butylammonium fluoride (1.0 M in THF, 1.5 eq.) was added to a solution of $4 \mathbf{a}$ or $4 \mathbf{b}$ $(1.0 \mathrm{mmol})$ in $\mathrm{THF}(10 \mathrm{~mL})$ at $0{ }^{\circ} \mathrm{C}$. The reaction mixture was warmed to room temperature and stirring was continued until complete conversion of the starting material was detected by TLC. Subsequently, the solution was diluted with $\mathrm{CH}_{2} \mathrm{Cl}_{2}(20 \mathrm{~mL})$ and washed with brine $(3 \times 10 \mathrm{~mL})$. The aqueous phase was extracted with $\mathrm{CH}_{2} \mathrm{Cl}_{2}(2 \times 20 \mathrm{~mL})$ and the combined organic phases were dried with $\mathrm{Na}_{2} \mathrm{SO}_{4}$. The solvent was evaporated and the residue was purified by column chromatography (petroleum ether/ethyl acetate 2:1 containing $0.5 \% \mathrm{Et}_{3} \mathrm{~N}$ ).

\section{2,6-Anhydro-5-deoxy-7-O-acetyl-1,3:8,9:11,12-tri-O-isopropylidene- $\beta$-D-manno-D-lyxo-dodeco-6-enitol (5a)}

Following general procedure A $5 \mathbf{a}$ was obtained as a white amorphous solid and was prepared from $4 \mathrm{a}$ in $71 \%$ yield stirring the reaction mixture for $20 \mathrm{~h} . \mathrm{R}_{\mathrm{f}}=0.28$ (petroleum ether/ethyl acetate $1: 1) \cdot[\alpha]_{\mathrm{D}}^{20}=+98.0\left(\mathrm{c}=1.0, \mathrm{CHCl}_{3}\right)$. M.p. $179{ }^{\circ} \mathrm{C}\left(n\right.$-hexane/ethyl acetate). ${ }^{1} \mathrm{H}-\mathrm{NMR}\left(400 \mathrm{MHz}, \mathrm{CDCl}_{3}\right)$ : $\delta(\mathrm{ppm})=5.14\left(\mathrm{~d}, J_{5,6}=2.2 \mathrm{~Hz}, 1 \mathrm{H}, \mathrm{H}-5\right), 4.88\left(\mathrm{dd}, J_{9,8}=5.7 \mathrm{~Hz}, J_{9,10}=3.5 \mathrm{~Hz}, 1 \mathrm{H}, \mathrm{H}-9\right), 4.71(\mathrm{~d}$, $\left.J_{8,9}=5.7 \mathrm{~Hz}, 1 \mathrm{H}, \mathrm{H}-8\right), 4.37-4.45$ (m, 2H, H-4, H-11), 4.01-4.12 (m, 3H, H-10, H-12a, H-12b), 3.85-3.94 (m, 2H, H-1a, H-1b), 3.68-3.80 (m, 2H, H-2, H-3), 2.02 (s, 3H, $\left.\mathrm{COCH}_{3}\right), 1.53,1.47,1.45,1.42,1.37,1.33$ $\left(6 \mathrm{~s}, 18 \mathrm{H}, \mathrm{C}\left(\mathrm{CH}_{3}\right)_{2}\right) .{ }^{13} \mathrm{C}-\mathrm{NMR}\left(101 \mathrm{MHz}, \mathrm{CDCl}_{3}\right): \delta(\mathrm{ppm})=168.2(\mathrm{CO}), 148.0(\mathrm{C}-6), 113.7,109.4$ $\left(\mathrm{C}\left(\mathrm{CH}_{3}\right)_{2}\right), 107.1(\mathrm{C}-7), 102.9(\mathrm{C}-5), 99.7\left(\mathrm{C}\left(\mathrm{CH}_{3}\right)_{2}\right), 86.3(\mathrm{C}-8), 81.5(\mathrm{C}-10), 79.6(\mathrm{C}-9), 73.2(\mathrm{C}-3), 72.8$ (C-11), 69.9 (C-2), 67.8 (C-4), 67.0 (C-12), $61.5(\mathrm{C}-1), 28.9,27.0,25.8,25.1,24.9\left(\mathrm{C}\left(\mathrm{CH}_{3}\right)_{2}\right), 21.6\left(\mathrm{COCH}_{3}\right)$,

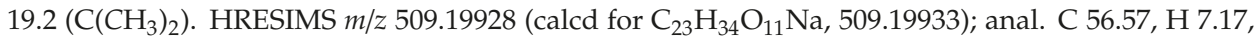
calcd for $\mathrm{C}_{23} \mathrm{H}_{34} \mathrm{O}_{11}, \mathrm{C} 56.78, \mathrm{H} 7.04$.

\section{2,6-Anhydro-5-deoxy-7-O-benzoyl-1,3:8,9:11,12-tri-O-isopropylidene- $\beta$-D-manno-D-lyxo-dodeco-6-enitol (5b)}

Following general procedure A $\mathbf{5 b}$ was obtained as a colorless amorphous solid and was prepared from $4 \mathbf{b}$ in $89 \%$ yield stirring the reaction mixture for $24 \mathrm{~h}$. $R_{\mathrm{f}}=0.37$ (petroleum ether/ethyl acetate 1:1). 
$[\alpha]_{\mathrm{D}}^{20}=+89.4\left(\mathrm{c}=1.0, \mathrm{CHCl}_{3}\right) .{ }^{1} \mathrm{H}-\mathrm{NMR}\left(400 \mathrm{MHz}, \mathrm{CDCl}_{3}\right): \delta(\mathrm{ppm})=7.92-7.99(\mathrm{~m}, 2 \mathrm{H}, \mathrm{Ph}), 7.54-7.60$ $(\mathrm{m}, 1 \mathrm{H}, \mathrm{Ph}), 7.41-7.47(\mathrm{~m}, 2 \mathrm{H}, \mathrm{Ph}), 5.26\left(\mathrm{~d}, J_{5,4}=2.2 \mathrm{~Hz}, 1 \mathrm{H}, \mathrm{H}-5\right), 4.99\left(\mathrm{dd}, J_{9,8}=5.9 \mathrm{~Hz}, J_{9,10}=3.6 \mathrm{~Hz}\right.$, $1 \mathrm{H}, \mathrm{H}-9), 4.95$ (d, $\left.J_{8,9}=5.9 \mathrm{~Hz}, 1 \mathrm{H}, \mathrm{H}-8\right), 4.41-4.50$ (m, 2H, H-4, H-11), 4.09-4.14 (m, 2H, H-10, H-12a), $4.04(\mathrm{dd}, J=9.1 \mathrm{~Hz}, J=4.2 \mathrm{~Hz}, 1 \mathrm{H}, \mathrm{H}-12 \mathrm{~b}), 3.72-3.88$ (m, 4H, H-1a, H-1b, H-2, H-3), 2.11 (br. s., $1 \mathrm{H}$, $\mathrm{OH}), 1.53,1.52,1.42,1.41,1.38,1.36\left(6 \mathrm{~s}, 18 \mathrm{H}, \mathrm{C}\left(\mathrm{CH}_{3}\right)_{2}\right) .{ }^{13} \mathrm{C}-\mathrm{NMR}\left(101 \mathrm{MHz}, \mathrm{CDCl}_{3}\right): \delta(\mathrm{ppm})=163.9$ (CO), $148.4(\mathrm{C}-6), 133.5,130.1,129.9,128.6(\mathrm{Ph}), 114.0,109.6\left(\mathrm{C}\left(\mathrm{CH}_{3}\right)_{2}\right), 107.9$ (C-7), $103.2(\mathrm{C}-5), 99.9$ $\left(\mathrm{C}\left(\mathrm{CH}_{3}\right)_{2}\right), 86.6$ (C-8), 82.0 (C-10), 79.9 (C-9), 73.4 (C-3), 73.0 (C-11), 70.2 (C-2), 68.1 (C-4), 67.2 (C-12), $61.6(\mathrm{C}-1), 29.1,27.1,26.0,25.2,25.1,19.4\left(\mathrm{C}_{(}\left(\mathrm{CH}_{3}\right)_{2}\right)$. HRESIMS $\mathrm{m} / z$ 571.21543 (calcd for $\mathrm{C}_{28} \mathrm{H}_{36} \mathrm{O}_{11} \mathrm{Na}$, 571.21498); anal. C 61.18, H 6.77, calcd for $\mathrm{C}_{28} \mathrm{H}_{36} \mathrm{O}_{11}, \mathrm{C} 61.30, \mathrm{H} 6.61$.

\section{General Procedure B for Epoxidation of $\mathbf{5} \mathbf{a}$ and $\mathbf{5} \mathbf{b}$ and Further Rearrangement to the Oxetanes}

To a solution of $m \mathrm{CPBA}$ (2.5 eq.) in $\mathrm{CH}_{2} \mathrm{Cl}_{2}(10 \mathrm{~mL}$ ) was added potassium fluoride (5 eq.) and the resulting suspension was stirred for $30 \mathrm{~min}$ at ambient temperature. A solution containing $\mathbf{5 a}$ or $5 \mathbf{b}(0.5 \mathrm{mmol})$ in $\mathrm{CH}_{2} \mathrm{Cl}_{2}(10 \mathrm{~mL})$ was added in one portion and stirring was continued for $2 \mathrm{~h}$ (epoxidation). To enforce the rearrangement to the oxetanes the reaction mixture was stirred for $20 \mathrm{~h}$, the white precipitate was filtered off and the solution was stirred for further $20 \mathrm{~h}$. The reaction was quenched by addition of sat. aq. $\mathrm{NaHCO}_{3}$-solution $(10 \mathrm{~mL})$ and sat. aq. $\mathrm{Na}_{2} \mathrm{~S}_{2} \mathrm{O}_{3}$-solution $(10 \mathrm{~mL})$. Subsequently, the aqueous layer was extracted by $\mathrm{CH}_{2} \mathrm{Cl}_{2}(3 \times 10 \mathrm{~mL})$, the combined organic layers were dried with $\mathrm{Na}_{2} \mathrm{SO}_{4}$, the solvent was removed and the crude product was purified by column chromatography.

5,6-Anhydro-7-O-acetyl-1,3:8,9:11,12-tri-O-isopropylidene- $\beta$-D-manno- $\beta$-D-manno-dodeco-6,7-diulo-2,6pyranose-7,10-furanose (6a)

Following general procedure B a mixture of $6 \mathbf{a}$ and $7 \mathbf{a}(8: 1)$ was obtained after quenching the reaction after $2 \mathrm{~h}$ as a white amorphous solid and was prepared from $5 \mathrm{a}$ in $94 \%$ yield. A mixture of petroleum ether/ethyl acetate $3: 1$ containing $0.5 \% \mathrm{Et}_{3} \mathrm{~N}$ was used as the eluent for column chromatography. $\mathrm{R}_{\mathrm{f}}=0.58$ (petroleum ether/ethyl acetate 1:2). ${ }^{1} \mathrm{H}-\mathrm{NMR}\left(400 \mathrm{MHz}, \mathrm{CDCl}_{3}\right)$ : $\delta(\mathrm{ppm})=4.96\left(\mathrm{~d}, J_{8,9}=6.0 \mathrm{~Hz}, 1 \mathrm{H}, \mathrm{H}-8\right), 4.91\left(\mathrm{dd}, J_{9,8}=6.0 \mathrm{~Hz}, J_{9,10}=3.9 \mathrm{~Hz}, 1 \mathrm{H}, \mathrm{H}-9\right), 4.31-4.38$ (m, 1H, H-11), $4.20\left(\mathrm{dd}, J_{10,11}=6.6 \mathrm{~Hz}, J_{10,9}=3.9 \mathrm{~Hz}, 1 \mathrm{H}, \mathrm{H}-10\right), 3.85-4.06(\mathrm{~m}, 5 \mathrm{H}, \mathrm{H}-1 \mathrm{a}, \mathrm{H}-3, \mathrm{H}-4$, H-12a, H-12b), 3.77 (dd, $J=10.7 \mathrm{~Hz}, J=10.7 \mathrm{~Hz}, 1 \mathrm{H}, \mathrm{H}-1 \mathrm{~b}), 3.66$ (d, $\left.J_{5,4}=2.4 \mathrm{~Hz}, 1 \mathrm{H}, \mathrm{H}-5\right), 3.49$ (ddd, $J=10.2 \mathrm{~Hz}, J=10.2 \mathrm{~Hz}, J=5.7 \mathrm{~Hz}, 1 \mathrm{H}, \mathrm{H}-2), 2.38$ (br. s., $1 \mathrm{H}, \mathrm{OH}), 2.06\left(\mathrm{~s}, 3 \mathrm{H}, \mathrm{COCH}_{3}\right), 1.57,1.48$, $1.42,1.39,1.35,1.33\left(6 \mathrm{~s}, 18 \mathrm{H}, \mathrm{C}\left(\mathrm{CH}_{3}\right)_{2}\right) .{ }^{13} \mathrm{C}-\mathrm{NMR}\left(101 \mathrm{MHz}, \mathrm{CDCl}_{3}\right): \delta(\mathrm{ppm})=169.2(\mathrm{CO}), 114.2$,

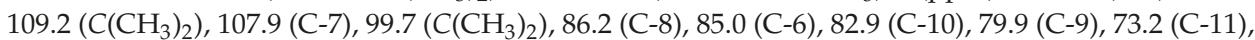
73.0 (C-3), 70.6 (C-2), 69.9 (C-4), 66.4, 61.7 (C-1), 57.3 (C-5), 29.1, 27.0, 25.6, 25.3, 24.6 (C( $\left.\left(\mathrm{CH}_{3}\right)_{2}\right), 21.9$

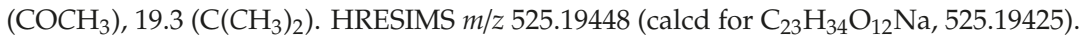

5,6-Anhydro-7-O-benzoyl-1,3:8,9:11,12-tri-O-isopropylidene- $\beta$-D-manno- $\beta$-D-manno-dodeco-6,7-diulo-2,6pyranose-7,10-furanose (6b)

Following general procedure B, a mixture of $\mathbf{6 b}$ and $7 \mathbf{b}(8: 1)$ was obtained after quenching the reaction after $2 \mathrm{~h}$ as a white amorphous solid and was prepared from $\mathbf{5 b}$ in $90 \%$ yield. A mixture of petroleum ether/ethyl acetate $3: 1$ containing $0.5 \% \mathrm{Et}_{3} \mathrm{~N}$ was used as the eluent for column chromatography. $\mathrm{R}_{\mathrm{f}}=0.64$ (petroleum ether/ethyl acetate 1:2). ${ }^{1} \mathrm{H}-\mathrm{NMR}\left(400 \mathrm{MHz}, \mathrm{CDCl}_{3}\right)$ : $\delta(\mathrm{ppm})=7.92-7.99(\mathrm{~m}, 2 \mathrm{H}, \mathrm{Ph}), 7.59-7.63(\mathrm{~m}, 1 \mathrm{H}, \mathrm{Ph}), 7.45-7.50(\mathrm{~m}, 2 \mathrm{H}, \mathrm{Ph}), 5.18\left(\mathrm{~d}, \mathrm{~J}_{8,9}=6.0 \mathrm{~Hz}\right.$, $1 \mathrm{H}, \mathrm{H}-8), 5.03\left(\mathrm{dd}, J_{9,8}=6.1 \mathrm{~Hz}, J_{9,10}=4.0 \mathrm{~Hz}, 1 \mathrm{H}, \mathrm{H}-9\right), 4.34-4.41(\mathrm{~m}, 1 \mathrm{H}, \mathrm{H}-11), 4.31(\mathrm{dd}$, $\left.J_{10,11}=6.6 \mathrm{~Hz}, J_{10,9}=3.9 \mathrm{~Hz}, 1 \mathrm{H}, \mathrm{H}-10\right), 4.13-4.18(\mathrm{~m}, 1 \mathrm{H}, \mathrm{H}-4), 4.03(\mathrm{dd}, J=8.9 \mathrm{~Hz}, J=6.2 \mathrm{~Hz}$, 1H, H-12a), 3.91-3.99 (m, 2H, H-3, 12b), 3.73-3.83 (m, 3H, H-1a, H-1b, H-5), 3.54 (ddd, $J=10.0 \mathrm{~Hz}$, $J=10.0 \mathrm{~Hz}, J=6.0 \mathrm{~Hz}, 1 \mathrm{H}, \mathrm{H}-2), 2.42$ (br. s., $1 \mathrm{H}, \mathrm{OH}), 1.62,1.48,1.39,1.37,1.34\left(5 \mathrm{~s}, 18 \mathrm{H}, \mathrm{C}\left(\mathrm{CH}_{3}\right)_{2}\right)$.

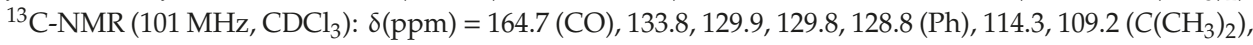

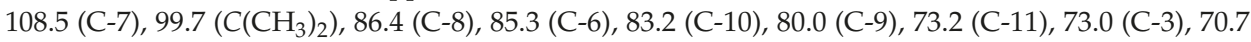


(C-2), 69.9 (C-4), 66.4 (C-12), 61.6 (C-1), 57.4 (C-5), 29.0, 26.9, 25.6, 25.3, 24.6, $19.3\left(\mathrm{C}\left(\mathrm{CH}_{3}\right)_{2}\right)$. HRESIMS $\mathrm{m} / \mathrm{z} 587.21029$ (calcd for $\mathrm{C}_{28} \mathrm{H}_{36} \mathrm{O}_{12} \mathrm{Na}, 587.20990$ ).

5,7-Anhydro-6-O-acetyl-1,3:8,9:11,12-tri-O-isopropylidene- $\beta$-D-manno- $\beta$-D-manno-dodeco-6,7-diulo-2,6pyranose-7,10-furanose (7a)

Following general procedure B 7a was obtained after quenching the reaction after $40 \mathrm{~h}$ as a white crystalline solid and was prepared from $5 \mathbf{a}$ in $70 \%$ yield. A mixture of petroleum ether/ethyl acetate 2:1 was used as the eluent for column chromatography. Crystals from 7a were grown by overlaying a saturated solution of $7 \mathrm{a}$ in methylene chloride with $n$-heptane and slowly evaporating the methylene chloride. $R_{\mathrm{f}}=0.51$ (petroleum ether/ethyl acetate 1:2). $[\alpha]_{\mathrm{D}}^{20}=+18.5\left(\mathrm{c}=1.0, \mathrm{CHCl}_{3}\right)$. M.p. $151^{\circ} \mathrm{C}$ (n-hexane/ethyl acetate). ${ }^{1} \mathrm{H}-\mathrm{NMR}\left(400 \mathrm{MHz}, \mathrm{CDCl}_{3}\right): \delta(\mathrm{ppm})=5.04\left(\mathrm{~d}, J_{8,9}=5.6 \mathrm{~Hz}, 1 \mathrm{H}, \mathrm{H}-8\right), 4.96$ $\left(\mathrm{d}, J_{4,5}=4.9 \mathrm{~Hz}, 1 \mathrm{H}, \mathrm{H}-5\right), 4.70\left(\mathrm{dd}, J_{9,8}=5.6 \mathrm{~Hz}, J_{9,10}=4.0 \mathrm{~Hz}, 1 \mathrm{H}, \mathrm{H}-9\right), 4.37-4.46$ (m, $\left.1 \mathrm{H}, \mathrm{H}-11\right)$, 4.00-4.13 (m, 3H, H-3, H-12a, H12b), 3.86-3.97 (m, 3H, H-1a, H-4, H-10), 3.80 (dd, J = 10.5 Hz, 1H, H-1b), $3.65-3.74(\mathrm{~m}, 1 \mathrm{H}, \mathrm{H}-2), 2.14\left(\mathrm{~d}, \mathrm{JOH}_{\mathrm{OH}}=9.0 \mathrm{~Hz}, 1 \mathrm{H}, \mathrm{OH}\right), 2.10\left(\mathrm{~s}, 3 \mathrm{H}, \mathrm{COCH}_{3}\right), 1.56,1.55,1.43,1.43,1.39$, $1.36\left(6 \mathrm{~s}, 18 \mathrm{H}, \mathrm{C}\left(\mathrm{CH}_{3}\right)_{2}\right) .{ }^{13} \mathrm{C}-\mathrm{NMR}\left(101 \mathrm{MHz}, \mathrm{CDCl}_{3}\right): \delta(\mathrm{ppm})=169.4(\mathrm{CO}), 114.2\left(\mathrm{C}_{\left.\left(\mathrm{CH}_{3}\right)_{2}\right), 112.9}\right.$

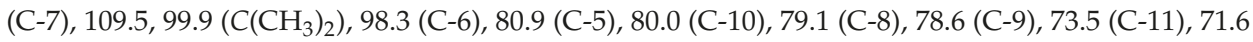
(C-3), 69.1 (C-2), 68.9 (C-4), 67.1 (C-12), $\left.61.8(\mathrm{C}-1), 29.1,27.1,25.9,25.8,25.4\left(\mathrm{C}_{(\mathrm{CH}}\right)_{2}\right), 21.2\left(\mathrm{COCH}_{3}\right)$,

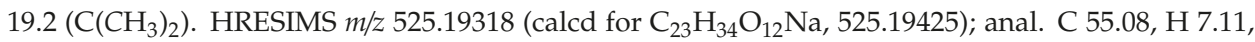
calcd for $\mathrm{C}_{23} \mathrm{H}_{34} \mathrm{O}_{12}, \mathrm{C} 54.97, \mathrm{H} 6.82$.

5,7-Anhydro-6-O-benzoyl-1,3:8,9:11,12-tri-O-isopropylidene- $\beta$-D-manno- $\beta$-D-manno-dodeco-6,7-diulo-2,6pyranose-7,10-furanose ( $7 \mathbf{b}$ )

Following general procedure B $7 \mathbf{b}$ was obtained after quenching the reaction after $40 \mathrm{~h}$ as a white amorphous solid and was prepared from $5 \mathbf{b}$ in $63 \%$ yield. A mixture of petroleum ether/ethyl acetate 2:1 was used as the eluent for column chromatography. $R_{\mathrm{f}}=0.60$ (petroleum ether/ethyl acetate 1:2). $[\alpha]_{\mathrm{D}}^{20}=+15.7\left(\mathrm{c}=1.0, \mathrm{CHCl}_{3}\right) .{ }^{1} \mathrm{H}-\mathrm{NMR}\left(400 \mathrm{MHz}\right.$, acetone- $\left.\mathrm{d}_{6}\right): \delta(\mathrm{ppm})=8.04-8.10(\mathrm{~m}, 2 \mathrm{H}, \mathrm{Ph})$, 7.68-7.74 (m, 1H, Ph), 7.53-7.59 (m, 2H, Ph), $5.16\left(\mathrm{~d}, J_{8,9}=5.6 \mathrm{~Hz}, 1 \mathrm{H}, \mathrm{H}-8\right), 5.10$ (d, $J_{5,4}=4.5 \mathrm{~Hz}$, $1 \mathrm{H}, \mathrm{H}-5), 4.82\left(\mathrm{dd}, J_{9,8}=5.6 \mathrm{~Hz}, J_{9,10}=3.7 \mathrm{~Hz}, 1 \mathrm{H}, \mathrm{H}-9\right), 4.36(\mathrm{ddd}, J=6.5 \mathrm{~Hz}, J=6.5 \mathrm{~Hz}, J=5.1 \mathrm{~Hz}$, 1H, H-11), 4.15-4.26 (m, 2H, H-3, OH), 3.99-4.06 (m, 3H, H-4, H-10, H-12a), 3.80-3.97 (m, 4H, H-1a, $\mathrm{H}-1 \mathrm{~b}, \mathrm{H}-2, \mathrm{H}-12 \mathrm{~b}), 1.52,1.51,1.37,1.35,1.34,1.28\left(6 \mathrm{~s}, 18 \mathrm{H}, \mathrm{C}\left(\mathrm{CH}_{3}\right)_{2}\right) .{ }^{13} \mathrm{C}-\mathrm{NMR}\left(101 \mathrm{MHz}\right.$, acetone- $\left.\mathrm{d}_{6}\right)$ : $\delta(\mathrm{ppm})=165.7(\mathrm{CO}), 135.0,130.8,130.2,129.7(\mathrm{Ph}), 114.2\left(\mathrm{C}_{\left.\left(\mathrm{CH}_{3}\right)_{2}\right),} 113.5(\mathrm{C}-7), 109.5,100.2\left(\mathrm{C}_{(\mathrm{CH}}\right)_{2}\right)$, 99.5 (C-6), 83.3 (C-5), 80.1 (C-10), 79.6 (C-9), 79.6 (C-8), 74.5 (C-11), 72.1 (C-3), 70.7 (C-2), 69.4 (C-4),

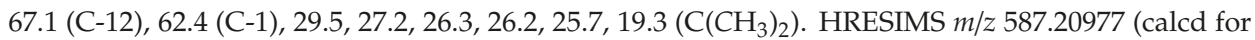
$\mathrm{C}_{28} \mathrm{H}_{36} \mathrm{O}_{12} \mathrm{Na}$, 587.20990); anal. C 59.64, H 6.86, calcd for $\mathrm{C}_{28} \mathrm{H}_{36} \mathrm{O}_{12}, \mathrm{C} 59.57$, H 6.43.

5,7-Anhydro-1,3:8,9:11,12-tri-O-isopropylidene- $\beta$-D-manno- $\beta$-D-manno-dodeco-6,7-diulo-2,6-pyranose-7,10furanose (8)

From $7 \mathbf{a}: 7 \mathbf{a}(50 \mathrm{mg}, 0.10 \mathrm{mmol})$ was dissolved in methanol $(2 \mathrm{~mL})$ and ammonia $(7 \mathrm{~N}$ in methanol, $280 \mu \mathrm{L}, 1.99 \mathrm{mmol}$ ) was added at ambient temperature. TLC indicated complete transformation of the starting material after $5 \mathrm{~h}$ and the volatile components were removed. Neat 8 (46 mg, $0.099 \mathrm{mmol}$, $99 \%$ ) remained as a white crystalline solid.

From $7 \mathbf{b}: 7 \mathbf{b}(20 \mathrm{mg}, 0.0354 \mathrm{mmol})$ was dissolved in methanol $(1 \mathrm{~mL})$ and ammonia $(7 \mathrm{~N}$ in methanol, $101 \mu \mathrm{L}, 0.708 \mathrm{mmol}$ ) was added at ambient temperature. TLC indicated complete transformation of the starting material after $5 \mathrm{~h}$ and the volatile components were removed. Subsequently, the crude product was purified by column chromatography (petroleum ether/ethyl acetate 1:2) and 8 (13 mg, $0.282 \mathrm{mmol}, 80 \%$ ) was isolated as a white crystalline solid.

$\mathrm{R}_{\mathrm{f}}=0.32$ (petroleum ether/ethyl acetate 1:3). $[\alpha]_{\mathrm{D}}^{20}=+17.5\left(\mathrm{c}=1.0, \mathrm{CHCl}_{3}\right)$. M.p. $122^{\circ} \mathrm{C}(n$-hexane). ${ }^{1} \mathrm{H}-\mathrm{NMR}\left(600 \mathrm{MHz}, \mathrm{DMSO}-d_{6}\right): \delta(\mathrm{ppm})=7.09(\mathrm{~s}, 1 \mathrm{H}, \mathrm{OH}-6), 5.16\left(\mathrm{~d}, J_{\mathrm{OH}, 4}=5.7 \mathrm{~Hz}, 1 \mathrm{H}, \mathrm{OH}-4\right), 4.75$ $\left(\mathrm{d}, J_{8,9}=5.9 \mathrm{~Hz}, 1 \mathrm{H}, \mathrm{H}-8\right), 4.57-4.63(\mathrm{~m}, 2 \mathrm{H}, \mathrm{H}-5, \mathrm{H}-9), 4.22\left(\mathrm{ddd}, J_{11,10}=7.3 \mathrm{~Hz}, J_{11,12 \mathrm{a}}=6.4 \mathrm{~Hz}\right.$, $\left.J_{11,12 \mathrm{~b}}=5.1,1 \mathrm{H}, \mathrm{H}-11\right), 4.01\left(\mathrm{dd}, J_{12 \mathrm{a}, 12 \mathrm{~b}}=8.4 \mathrm{~Hz}, J_{12 \mathrm{a}, 11}=6.4 \mathrm{~Hz}, 1 \mathrm{H}, \mathrm{H}-12 \mathrm{a}\right), 3.92\left(\mathrm{dd}, J_{12 \mathrm{~b}, 12 \mathrm{a}}=8.4 \mathrm{~Hz}\right.$, 
$\left.J_{12 \mathrm{~b}, 11}=5.1 \mathrm{~Hz}, 1 \mathrm{H}, \mathrm{H}-12 \mathrm{~b}\right), 3.78-3.85(\mathrm{~m}, 2 \mathrm{H}, \mathrm{H}-1 \mathrm{a}, \mathrm{H}-3), 3.76\left(\mathrm{dd}, J_{10,11}=7.3 \mathrm{~Hz}, J_{10,9}=3.7 \mathrm{~Hz}\right.$, $1 \mathrm{H}, \mathrm{H}-10), 3.68\left(\mathrm{dd}, J_{1 \mathrm{~b}, 1 \mathrm{a}}=10.5 \mathrm{~Hz}, J_{1 \mathrm{~b}, 2}=10.5 \mathrm{~Hz}, 1 \mathrm{H}, \mathrm{H}-1 \mathrm{~b}\right), 3.52\left(\mathrm{ddd}, J=9.7 \mathrm{~Hz}, J_{4, \mathrm{OH}}=5.1 \mathrm{~Hz}\right.$, $J=4.4 \mathrm{~Hz}, 1 \mathrm{H}, \mathrm{H}-4), 3.40\left(\mathrm{ddd}, J_{2,1 \mathrm{~b}}=9.9 \mathrm{~Hz}, J=9.9 \mathrm{~Hz}, J=5.8 \mathrm{~Hz}, 1 \mathrm{H}, \mathrm{H}-2\right), 1.45,1.39,1.32,1.31$, $1.28,1.26\left(6 \mathrm{~s}, 18 \mathrm{H}, \mathrm{C}\left(\mathrm{CH}_{3}\right)_{2}\right){ }^{13} \mathrm{C}-\mathrm{NMR}\left(101 \mathrm{MHz}, \mathrm{DMSO}-d_{6}\right): \delta(\mathrm{ppm})=112.5(\mathrm{C}-7), 112.3,108.2,98.8$

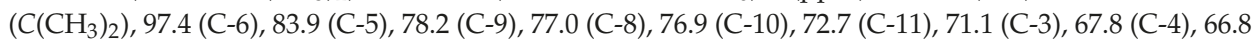

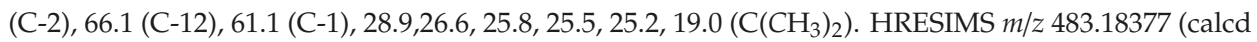
for $\mathrm{C}_{21} \mathrm{H}_{32} \mathrm{O}_{11} \mathrm{Na}$, 483.18368); anal. C 54.58, $\mathrm{H}$ 7.41, calcd for $\mathrm{C}_{21} \mathrm{H}_{32} \mathrm{O}_{11}, \mathrm{C} 54.78, \mathrm{H}$ 7.00.

\section{Conclusions}

In summary, we have demonstrated that the stability of 2,5-anhydro sugars depends on their chemical environment. In the case of epoxide $\mathbf{6} \mathbf{a}$ and $\mathbf{6} \mathbf{b}$, where an ester group is adjacent to the epoxide group, reversible rearrangements to highly annulated oxetane-bridged disaccharides $7 \mathbf{a}$ and $7 \mathrm{~b}$ occur. In further studies, these compounds serve as precursors for the synthesis of symmetrical dodeco-6,7-diuloses.

Supplementary Materials: The following are available online, ${ }^{1} \mathrm{H}-\mathrm{NMR}$ and ${ }^{13} \mathrm{C}-\mathrm{NMR}$ spectra of all compounds, H,H-NOESY-NMR spectra of compounds $4 \mathbf{a}$ and $\mathbf{4 b}$ and X-ray data of compounds $5 \mathbf{a}$ and $7 \mathbf{a}$.

Author Contributions: Synthesis, conceptualization, investigation, writing—original draft preparation, formal analysis, M.B.; X-ray crystallography, C.M.-M.; conceptualization, investigation, writing-review and editing, validation, supervision, T.Z. All authors have read and agreed to the published version of the manuscript.

Funding: This research received no external funding.

Acknowledgments: We thank Petra Schülzle (elemental analysis), Dorothee Wistuba, Claudia Kruse and Peter Haiss (mass spectra) for their contributions to this work.

Conflicts of Interest: The authors declare no conflict of interest.

\section{References}

1. Hadzic, P.; Popsavin, M.; Borozan, S. Alkylating ability of carbohydrate oxetanes: Practical synthesis of bolaform skeleton derivative. J. Serb. Chem. Soc. 2015, 80, 1273-1278. [CrossRef]

2. Kawana, M.; Kuzuhara, H.; Emoto, S. The Use of Grignard Reagents in the Synthesis of Carbohydrates. III. The One-way Anomerization of Methyl Glycofuranosides and the Opening of Their Furanose Rings. Bull. Chem. Soc. Jpn. 1981, 54, 1492-1504. [CrossRef]

3. Hadzic, P.; Vukojevic, N.; Popsavin, M.; Canadi, J. Nucleophilic opening of the 3,5-anhydro ring in 1,2-O-cyclohexylidene-D-xylofuranose. J. Serb. Chem. Soc. 2001, 66, 1-8. [CrossRef]

4. Telli, F.Ç.; Ay, K.; Murat, G.; Kök, G.; Salman, Y. Acid promoted intramolecular formation of 3,5-anhydro-1,4-furano-7-ulose derivatives via the Wittig-cyclization procedure and their antimicrobial properties. Med. Chem. Res. 2013, 22, 2253-2259. [CrossRef]

5. Ong, K.-S.; Whistler, R.L. Photochemical addition of acetone to D-glucal triacetate and subsequent oxetane ring cleavage. J. Org. Chem. 1972, 37, 572-574. [CrossRef]

6. Brunckova, J.; Crich, D. Intramolecular hydrogen atom abstraction: The $\beta$-oxygen effect in the Norrish type II photoreaction. Tetrahedron 1995, 51, 11945-11952. [CrossRef]

7. Lichtenthaler, F.W.; Weimer, T.; Immel, S. [4+2] and [2+2] Photocycloadditions of 1,2-diketones to glycal and hydroxyglycal esters. Tetrahedron Asymmetry 2004, 15, 2703-2709. [CrossRef]

8. Craig, D.; Tierney, J.P.; Williamson, C. Template-directed intramolecular C-glycosidation. Stereoselective synthesis of bicyclic ketooxetanes from anomeric sulfones. Tetrahedron Lett. 1997, 38, 4153-4156. [CrossRef]

9. Craig, D.; Munasinghe, V.R.N.; Tierney, J.P.; White, A.J.P.; Williams, D.J.; Williamson, C. Template-directed intramolecular C-glycosidation. cation-mediated synthesis of ketooxetanes from thioglycosides. Tetrahedron 1999, 55, 15025-15044. [CrossRef]

10. Schulze, O.; Voss, J.; Adiwidjaja, G. Convenient preparation of 3,5-anhydro- and 2,5-anhydropentofuranosides, and 5,6-anhydro-d-glucofuranose by use of the Mitsunobu reaction. Carbohydr. Res. 2005, 340, 587-595. [CrossRef] [PubMed] 
11. Bayer, M.; Bächle, F.; Ziegler, T. Synthesis and Pd-catalyzed coupling of 1-C-stannylated glycals. J. Carbohydr. Chem. 2018, 37, 347-369. [CrossRef]

12. Oddo, A.; Holl, R. Design and stereoselective synthesis of a $C$-aryl furanoside as a conformationally constrained CHIR-090 analogue. Carbohydr. Res. 2012, 359, 59-64. [CrossRef] [PubMed]

13. Mochizuki, T.; Shiozaki, M. Synthesis of (6R,7R)-D-gluco-L-gulo-6,7-dodecodiulose-(6,2),(7,11). Chem. Lett. 1997, 26, 801-802. [CrossRef]

14. Jarowicki, K.; Kilner, C.; Kocienski, P.J.; Komsta, Z.; Milne, J.E.; Wojtasiewicz, A.; Coombs, V. A synthesis of 1-lithiated glycals and 1-tributylstannyl glycals from 1-phenylsulfinyl glycals via sulfoxide-lithium ligand exchange. Synthesis 2008, 2008, 2747-2763.

15. Marín, I.; Matheu, M.I.; Díaz, Y.; Castillón, S. Stereoselective Tandem Epoxidation-Alcoholysis/Hydrolysis of Glycals with Molybdenum Catalysts. Adv. Synth. Catal. 2010, 352, 3407-3418. [CrossRef]

16. Borowski, D.; Zweiböhmer, T.; Ziegler, T. 1,2-Annulated Sugars: Synthesis of Polyhydroxylated 2,10-Dioxadecalins with $\beta$-manno Configuration. Eur. J. Org. Chem. 2016, 2016, 5248-5256. [CrossRef]

17. Borowski, D.; Maichle-Mössmer, C.; Ziegler, T. Synthetic Adventures with 2-C-Branched Carbohydrates: 4-C-Formyl Branched Octoses with Structural Analogy to Bradyrhizose. Eur. J. Org. Chem. 2019, 2019, 2653-2670. [CrossRef]

18. Bellucci, G.; Catelani, G.; Chiappe, C.; D'Andrea, F. A simple and highly diastereoselective preparation of glycal epoxides using the MCPBA-KF complex. Tetrahedron Lett. 1994, 35, 8433-8436. [CrossRef]

19. Camps, F.; Coll, J.; Messeguer, A.; Pujol, F. m-Chloroperoxybenzoic acid-potassium fluoride system: Study of its stability and reaction with. alpha.-methylstyrene. J. Org. Chem. 1982, 47, 5402-5404. [CrossRef]

(C) 2020 by the authors. Licensee MDPI, Basel, Switzerland. This article is an open access article distributed under the terms and conditions of the Creative Commons Attribution (CC BY) license (http://creativecommons.org/licenses/by/4.0/). 



\title{
Communication
}

\section{Synthesis and Isolation of Diastereomeric Anomeric Sulfoxides from a D-Mannuronate Thioglycoside Building Block}

\author{
Eleni Dimitriou and Gavin J. Miller * \\ Lennard-Jones Laboratory, School of Chemical and Physical Sciences, Keele University, Keele, \\ Staffordshire ST5 5BG, UK; e.dimitriou@keele.ac.uk \\ * Correspondence: g.j.miller@keele.ac.uk; Tel.: +44-1782-734442
}

Received: 13 December 2019; Accepted: 16 January 2020; Published: 18 January 2020

\begin{abstract}
Methyl [S-phenyl 4-O-acetyl-2,3-di-O-benzyl-1-thio- $\alpha$-D-mannopyranoside $(\mathrm{R} / \mathrm{S})_{\mathrm{S}}$-oxide] uronate was synthesised from a thioglycoside mannosyl uronate donor in a $98 \%$ yield. By using one equivalent of meta-chloroperbenzoic acid (m-CPBA) as the sulphur oxidant, a smooth conversion to the diastereomeric sulfoxide products was achieved. The product was fully characterized by ${ }^{1} \mathrm{H}$, ${ }^{13} \mathrm{C}$ and $2 \mathrm{D}$ NMR alongside MS analysis.
\end{abstract}

Keywords: glycosyl sulfoxide; uronate; thioglycoside oxidation; mannose

\section{Introduction}

Glycosyl sulfoxides have been successfully used as glycosyl donors within carbohydrate synthesis ever since a report by Kahne and co-workers in which they activated an anomeric sulfoxide with triflic anhydride to glycosylate a deoxycholic ester derivative [1]. Since then, glycosyl sulfoxides' use has continued, along with developments in mechanistically understanding their role in glycosylation reactions [2]. Glycosyl sulfoxides are traditionally formed by the careful oxidation of a parent thioglycoside component to form an S-oxide, typically by using meta-chloroperbenzoic acid (m-CPBA) as the oxidant, although other methods, including $\mathrm{OXONE}^{\circledR}$, have recently been developed [3,4]. Whilst the oxidation generally proceeds to yield diastereomeric mixtures, stereoselective sulfoxidations have been reported for particular classes of parent thioglycosides, e.g., $\alpha$-mannopyranose thioglycosides [5-7].

Uronic acids, where the C6 pyranosyl carbon is at the carboxylic acid oxidation level, have also been prepared as glycosyl sulfoxide donors for the synthesis of oligosaccharide targets that contain D-glucuronic acid [8]. As part of a wider project concerning the chemical synthesis of alginate oligosaccharides [9], we required access to a D-mannuronic acid glycosyl sulfoxide building block (3) and provide here our record of its synthesis and full characterization from $S$-phenyl thioglycoside (2).

\section{Results}

Starting from D-mannose 1, we prepared thioglycoside uronate donor 2 by using established procedures (Scheme 1) [10-14]. Briefly, peracetylation of $\mathbf{1}$ followed by anomeric thioglycosidation using $\mathrm{PhSH} / \mathrm{BF}_{3} \cdot \mathrm{Et}_{2} \mathrm{O}$ enabled global deacetylation and 4,6-benzylidenation. The benzyl protection of the remaining hydroxy groups was then followed by 4,6-benzylidene hydrolysis to allow for regioselective $\mathrm{C} 6$ oxidation of the corresponding mannuronic acid. Finally, methylation of the carboxylic acid and 4-OH protection with acetate delivered thioglycoside donor 2 .

We next pursued the preparation of glycosyl sulfoxide 3 by using one equivalent of $\mathrm{m}$-CPBA as the oxidant at $-78^{\circ} \mathrm{C}$ (Scheme 1). Following the addition of the oxidant, the reaction was slowly allowed to warm to $-30^{\circ} \mathrm{C}$ over four hours. Thin layer chromatography (TLC) analysis at this point showed 
the appearance of two new, lower $R_{\mathrm{f}}$ spots, which were indicative of an oxidised material. Following workup, ${ }^{1} \mathrm{H}$ NMR analysis of the crude residue indicated that a mixture of sulfoxide diastereomers had formed (3major:3minor, 2:1). The diastereoisomers were separated by column chromatography and analytical data collected for both.
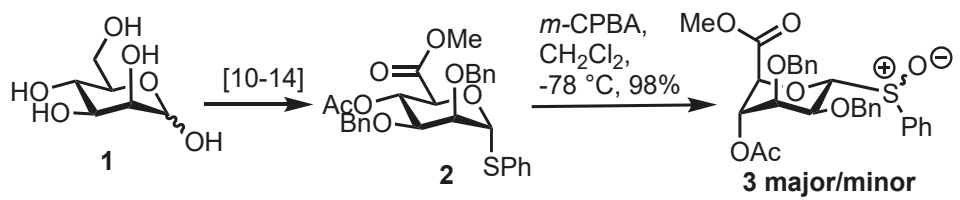

Scheme 1. Synthesis of methyl [S-phenyl 4-O-acetyl-2,3-di-O-benzyl-1-thio- $\alpha$-D-mannopyranoside $(\mathrm{R} / \mathrm{S})_{\mathrm{S}}$-oxide] uronate 3 from thioglycoside 2.

For the major diastereoisomer, an analysis of the ${ }^{1} \mathrm{H}$ NMR data [5.11 ppm (d (doublet), $J=10.1$ $\mathrm{Hz}, \mathrm{H} 1)]$ suggested that the product adopted a ${ }^{1} \mathrm{C}_{4}$ conformation in solution and the $\mathrm{H} 1-\mathrm{H} 2$ coupling supported a trans-diaxial relationship. This observation was further supported by the multiplicity for $\mathrm{H} 4$ (dd (doublet of doublets), $J=3.9,1.4 \mathrm{~Hz}$ ), which was distinct from the usual trans-diaxial coupling observed for ${ }^{4} \mathrm{C}_{1}$ mannose derivatives (Figure 1). The coupling observed for the minor diastereoisomer was different $[5.26 \mathrm{ppm}(\mathrm{br} \mathrm{d}, J=7.4 \mathrm{~Hz}, \mathrm{H1})]$ and more closely matched the $J$ value that was observed for $2[5.80 \mathrm{ppm}(\mathrm{d}, J=7.1 \mathrm{~Hz}, \mathrm{H} 1)]$, thus suggesting that the barrier to interconvert between ${ }^{1} \mathrm{C}_{4}$ and ${ }^{4} C_{1}$ was lower for this diastereoisomer, as evidenced by signal broadening and $J$ value averaging in the ${ }^{1} \mathrm{H}$ NMR spectrum. Diastereomeric sulfoxide 3 is currently being evaluated as a glycosyl donor for the synthesis of mannonate-containing oligosaccharides. Copies of NMR data for the major and minor isomers of $\mathbf{3}$ are included in the Supplementary Materials.

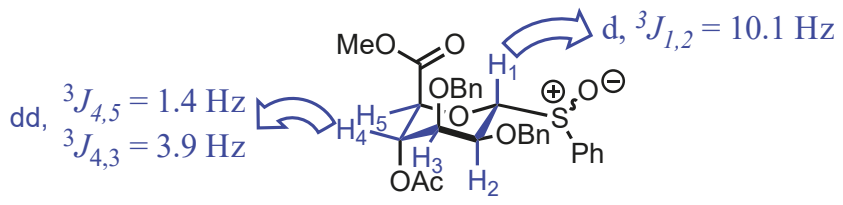

Figure 1. Indication of ${ }^{1} \mathrm{C}_{4}$ conformation for (3) using ${ }^{1} \mathrm{H}$ NMR coupling constant data.

\section{Materials and Methods}

\subsection{General}

All reagents and solvents that were available commercially were purchased from Acros Organics ${ }^{\mathrm{TM}}$ Belgium, Alfa AesarTM Ward Hill, MA, Fisher Scientific ${ }^{\mathrm{TM}}$ Waltham MA, or Sigma Aldrich ${ }^{\mathrm{TM}}$ St. Louis $\mathrm{MO}$. All reactions in non-aqueous solvents were conducted in flame-dried glassware under a nitrogen atmosphere with a magnetic stirring device. Solvents were purified by passing through activated alumina columns, used directly from a PureSolv-MD solvent purification system, and transferred under nitrogen. Reactions requiring low temperatures used the following cooling baths: $-78{ }^{\circ} \mathrm{C}$ (dry ice). Infrared spectra were neatly recorded on a Perkin Elmer Spectrum 100 FT-IR spectrometer; selected absorbencies $\left(v_{\max }\right)$ are reported in $\mathrm{cm}^{-1}$. ${ }^{1} \mathrm{H}$ NMR spectra were recorded at $400 \mathrm{MHz}$, and ${ }^{13} \mathrm{C}$ spectra were recorded at $100 \mathrm{MHz}$ with the use of a Bruker AVIII 400 spectrometer. ${ }^{1} \mathrm{H}$ NMR signals were assigned with the aid of gDQCOSY. ${ }^{13} \mathrm{C}$ NMR signals were assigned with the aid of gHSQCAD. Coupling constants are reported in Hertz. Chemical shifts ( $\delta$, in ppm) were standardized against the deuterated solvent peak. NMR data were analysed with the Nucleomatica iNMR software. ${ }^{1} \mathrm{H}$ NMR splitting patterns were assigned as follows: $\mathrm{s}$ (singlet), br d (broad doublet), $\mathrm{d}$ (doublet), $\mathrm{t}$ (triplet), $\mathrm{dd}$ (doublet of doublets), ddd (doublet of doublet of doublets), or m (multiplet and/or multiple resonances). Reactions were followed by TLC by using Merck silica gel 60F254 analytical plates (aluminium support) 
and were developed with the use of standard visualising agents: short wave UV radiation $(245 \mathrm{~nm})$ and $5 \%$ sulfuric acid in methanol/ $\Delta$. Purification via flash column chromatography was conducted by using silica gel $60(0.043-0.063 \mathrm{~mm})$. Optical activities were recorded on a Rudolph autopol I automatic polarimeter (concentration in g/100mL). MS and HRMS (ESI) were obtained on Waters (Xevo, G2-XS TOF) or Waters Micromass LCT spectrometers by using a methanol mobile phase. High resolution (ESI) spectra were obtained on a Xevo, G2-XS TOF mass spectrometer.

\subsection{Methyl [S-phenyl 4-O-acetyl-2,3-di-O-benzyl-1-thio- $\alpha$-D-mannopyranoside $(R / S)_{S}$-oxide] uronate 3}

m-CPBA (66 mg, $0.38 \mathrm{mmol}, 1.0$ equiv.) was added to a stirred solution of $2(200 \mathrm{mg}, 0.38 \mathrm{mmol}$, 1.0 equiv.) in $\mathrm{CH}_{2} \mathrm{Cl}_{2}(20 \mathrm{~mL})$ at $-78{ }^{\circ} \mathrm{C}$, followed by warming to $-30{ }^{\circ} \mathrm{C}$ over $4 \mathrm{~h}$, whereupon TLC analysis (EtOAc/hexane, 1/2) indicated that no starting material remained. The reaction was quenched by the addition of a saturated aqueous $\mathrm{NaHCO}_{3}$ solution $(25 \mathrm{~mL})$ and the organic layer separated and washed with brine $(2 \times 25 \mathrm{~mL})$. The organic layer was dried $\left(\mathrm{MgSO}_{4}\right)$, filtered, and concentrated under reduced pressure, furnishing crude 3 as a yellow oil. Purification was conducted with the use of silica gel flash column chromatography eluting with EtOAc/hexane (0/100, 20/80, 40/60, 90/10) to afford (3) (201 mg, $0.34 \mathrm{mmol}, 98 \%$ ) as two separable diastereoisomers (3major:3minor, 2:1, $132 \mathrm{mg}: 69 \mathrm{mg}$ ).

Analytical data for 3minor. $\mathrm{R}_{\mathrm{f}} 0.18$ (EtOAc/hexane, $\left.1 / 2\right) ;[\alpha]_{\mathrm{D}}^{26}+100$ (c. 1.0, $\left.\mathrm{CHCl}_{3}\right) ;{ }^{1} \mathrm{H} \mathrm{NMR}(400 \mathrm{MHz}$; $\left.\mathrm{CDCl}_{3}\right) \delta 7.63-6.91(15 \mathrm{H}, \mathrm{m}, \mathrm{ArH}), 5.51(1 \mathrm{H}, \mathrm{dd}, \mathrm{J}=5.3,3.4 \mathrm{~Hz}, \mathrm{H} 4), 5.24(1 \mathrm{H}, \mathrm{d}, \mathrm{J}=7.4 \mathrm{~Hz}, \mathrm{H1}), 4.57$ $(1 \mathrm{H}, \mathrm{d}, \mathrm{J}=3.2, \mathrm{~Hz}, \mathrm{H} 5), 4.50\left(1 \mathrm{H}, \mathrm{d}, \mathrm{J}=12.9 \mathrm{~Hz}, \mathrm{CH}_{2} \mathrm{Ph}\right.$-attached to C3), $4.47(1 \mathrm{H}, \mathrm{d}, \mathrm{J}=12.6 \mathrm{~Hz}$, $\mathrm{CH}_{2}$ Ph-attached to $\left.\mathrm{C} 3\right), 4.40\left(1 \mathrm{H}, \mathrm{d}, \mathrm{J}=11.8 \mathrm{~Hz}, \mathrm{CH}_{2} \mathrm{Ph}\right.$-attached to $\left.\mathrm{C} 2\right), 4.33(1 \mathrm{H}, \mathrm{d}, \mathrm{J}=11.8 \mathrm{~Hz}$, $\mathrm{CH}_{2}$ Ph-attached to C2), $4.05(1 \mathrm{H}, \mathrm{dd}, \mathrm{J}=7.5,2.9 \mathrm{~Hz}, \mathrm{H} 2), 3.92(1 \mathrm{H}, \mathrm{dd}, \mathrm{J}=5.0,2.8 \mathrm{~Hz}, \mathrm{H} 3), 3.58(3 \mathrm{H}$, $\left.\mathrm{s}, \mathrm{CO}_{2} \mathrm{CH}_{3}\right), 2.05\left(3 \mathrm{H}, \mathrm{s}, \mathrm{C}(\mathrm{O}) \mathrm{CH}_{3}\right) ;{ }^{13} \mathrm{C} \mathrm{NMR}\left(101 \mathrm{MHz} ; \mathrm{CDCl}_{3}\right) \delta 169.7\left(\mathrm{C}=\mathrm{O}\right.$ of $\left.\mathrm{C}(\mathrm{O}) \mathrm{CH}_{3}\right), 168.1$ $\left(\mathrm{C}=\mathrm{O}\right.$ of $\left.\mathrm{CO}_{2} \mathrm{CH}_{3}\right), 140.7,137.3,137.3,130.7,128.9,128.3,128.2,127.9,127.7,127.7,124.5,92.2(\mathrm{C} 1), 74.5$ (C5), 73.2 (C3), $72.7\left(\mathrm{CH}_{2}\right.$ Ph-attached to $\left.\mathrm{C} 3\right), 71.2\left(\mathrm{CH}_{2}\right.$ Ph-attached to $\left.\mathrm{C} 2\right), 70.0$ (C2), $69.4(\mathrm{C} 4), 52.4$ $\left(\mathrm{CO}_{2} \mathrm{CH}_{3}\right), 20.9\left(\mathrm{C}(\mathrm{O}) \mathrm{CH}_{3}\right)$; LRMS $\left(\mathrm{ESI}^{+}\right) \mathrm{m} / z 539\left[(\mathrm{M}+\mathrm{H})^{+}, 100 \%\right] ; \mathrm{HRMS}\left(\mathrm{ESI}^{+}\right) \mathrm{m} / z$ Found: $(\mathrm{M}+$ $\mathrm{H})^{+} 539.1739 \mathrm{C}_{29} \mathrm{H}_{30} \mathrm{O}_{8} \mathrm{~S}$ requires $(\mathrm{M}+\mathrm{H})^{+}, 539.1734 ; \mathrm{IR} v \max / \mathrm{cm}^{-1} 1735$ (s, C=O), $1183(\mathrm{~s}, \mathrm{C}-\mathrm{O}), 1143$ (s, C-O), $1074(\mathrm{~s}, \mathrm{~S}=\mathrm{O})$.

Analytical data for 3major. $\mathrm{R}_{\mathrm{f}} 0.10$ (EtOAc/hexane, $\left.1 / 2\right) ;[\alpha]_{\mathrm{D}}^{26}-2.3$ (c. $\left.1.0, \mathrm{CHCl}_{3}\right) ;{ }^{1} \mathrm{H} \mathrm{NMR}(400 \mathrm{MHz}$;

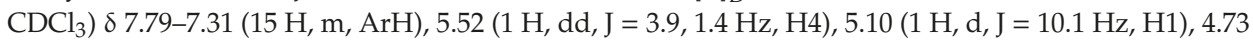
$\left(1 \mathrm{H}, \mathrm{d}, \mathrm{J}=11.1 \mathrm{~Hz}, \mathrm{CH}_{2} \mathrm{Ph}\right.$-attached to $\mathrm{C} 2$ or C3), $4.62\left(1 \mathrm{H}, \mathrm{d}, \mathrm{J}=12.0 \mathrm{~Hz}, \mathrm{CH}_{2} \mathrm{Ph}\right.$-attached to $\mathrm{C} 2$ or C3), 4.58 ( $2 \mathrm{H}, \mathrm{d}, \mathrm{J}=12.0 \mathrm{~Hz}, \mathrm{CH}_{2} \mathrm{Ph}$-attached to $\mathrm{C} 2$ or C3), $4.57\left(1 \mathrm{H}, \mathrm{d}, \mathrm{J}=11.1 \mathrm{~Hz}, \mathrm{CH}_{2} \mathrm{Ph}\right.$-attached to $\mathrm{C} 2$ or C3), $4.39(1 \mathrm{H}, \mathrm{d}, \mathrm{J}=1.0 \mathrm{~Hz}, \mathrm{H} 5), 4.21$ (1 H, dd, J = 10.1, 2.7 Hz, H2), 3.92-3.90 (1 H, m, H3), $3.42\left(3 \mathrm{H}, \mathrm{s}, \mathrm{CO}_{2} \mathrm{CH}_{3}\right), 2.09\left(3 \mathrm{H}, \mathrm{s}, \mathrm{C}(\mathrm{O}) \mathrm{CH}_{3}\right) ;{ }^{13} \mathrm{C} \mathrm{NMR}\left(101 \mathrm{MHz} ; \mathrm{CDCl}_{3}\right) \delta 170.0\left(\mathrm{C}=\mathrm{O}\right.$ of $\left.\mathrm{C}(\mathrm{O}) \mathrm{CH}_{3}\right)$, $167.9\left(\mathrm{C}=\mathrm{O}\right.$ of $\left.\mathrm{CO}_{2} \mathrm{CH}_{3}\right), 137.0,137.0,130.6,128.6,128.5,128.4,128.4,128.2,128.1,128.0,125.1,86.8(\mathrm{C} 1)$, 74.5 (C5), $72.6\left(\mathrm{CH}_{2} \mathrm{Ph}\right.$-attached to $\mathrm{C} 2$ or $\left.\mathrm{C} 3\right), 72.4\left(\mathrm{CH}_{2} \mathrm{Ph}\right.$-attached to $\mathrm{C} 2$ or $\left.\mathrm{C} 3\right), 72.4(\mathrm{C} 3), 70.6$ (C2), $69.4(\mathrm{C} 4), 52.1\left(\mathrm{CO}_{2} \mathrm{CH}_{3}\right), 21.1\left(\mathrm{C}(\mathrm{O}) \mathrm{CH}_{3}\right)$; LRMS $\left(\mathrm{ESI}^{+}\right) \mathrm{m} / \mathrm{z} 539\left[(\mathrm{M}+\mathrm{H})^{+}, 100 \%\right] ; \mathrm{HRMS}\left(\mathrm{ESI}^{+}\right) \mathrm{m} / z$ Found: $(\mathrm{M}+\mathrm{H})^{+} 539.1719 \mathrm{C}_{29} \mathrm{H}_{30} \mathrm{O}_{8} \mathrm{~S}$ requires $(\mathrm{M}+\mathrm{H})^{+}, 539.1734 ; \mathrm{IR}$ vmax/cm ${ }^{-1} 1735(\mathrm{~s}, \mathrm{C}=\mathrm{O}), 1183$ (s, C-O), 1143 (s, C-O), 1074 (s, S=O).

Supplementary Materials: The following are available online, Figure S1: ${ }^{1} \mathrm{H}$ NMR spectrum of compound 3 major, Figure S2: ${ }^{13} \mathrm{C}$ NMR spectrum of compound 3major, Figure S3: ${ }^{1} \mathrm{H}$ NMR spectrum of compound 3minor, Figure S4: ${ }^{13} \mathrm{C}$ NMR spectrum of compound 3minor.

Author Contributions: E.D. and G.J.M. conceived and designed the experiments; E.D. performed the experiments and analysed the data; G.J.M. and E.D. wrote the manuscript. All authors have read and agreed to the published version of the manuscript.

Funding: This research received no external funding.

Acknowledgments: University are thanked for a PhD studentship to E.D. and the EPSRC UK National Mass Spectrometry Facility (NMSF) at Swansea University are thanked for MS analyses.

Conflicts of Interest: The authors declare no conflict of interest. 


\section{References}

1. Kahne, D.; Walker, S.; Cheng, Y.; Vanengen, D.J. Glycosylation of unreactive substrates. J. Am. Chem. Soc. 1989, 111, 6881-6882. [CrossRef]

2. Fascione, M.A.; Brabham, R.; Turnbull, W.B. Mechanistic Investigations into the Application of Sulfoxides in Carbohydrate Synthesis. Chem. Eur. J. 2016, 22, 3916-3928. [CrossRef] [PubMed]

3. Chen, M.-Y.; Patkar, L.N.; Lin, C.-C. Selective Oxidation of Glycosyl Sulfides to Sulfoxides Using Magnesium Monoperoxyphthalate and Microwave Irradiation. J. Org. Chem. 2004, 69, 2884-2887. [CrossRef] [PubMed]

4. Chen, M.-Y.; Patkar, L.N.; Chen, H.-T.; Lin, C.-C. An efficient and selective method for preparing glycosyl sulfoxides by oxidizing glycosyl sulfides with $\mathrm{OXONE}$ or $t$ - $\mathrm{BuOOH}$ on $\mathrm{SiO}_{2}$. Carbohydr. Res. 2003, 338, 1327-1332. [CrossRef]

5. Crich, D.; Mataka, J.; Zakharov, L.N.; Rheingold, A.L.; Wink, D.J.J. Stereoselective Formation of Glycosyl Sulfoxides and Their Subsequent Equilibration: Ring Inversion of an $\alpha$-Xylopyranosyl Sulfoxide Dependent on the Configuration at Sulfur. J. Am. Chem. Soc. 2002, 124, 6028-6036. [CrossRef] [PubMed]

6. Crich, D.; Mataka, J.; Sun, S.; Wink, D.J.; Lam, K.C.; Rheingold, A.L. Stereoselective sulfoxidation of $\alpha$-mannopyranosyl thioglycosides: The exo-anomeric effect in action. Chem. Commun. 1998, 2763-2764. [CrossRef]

7. Poláková, M.; Jankovič, L'.; Kucková, L.; Kožíšek, J. Application of oxone immobilized on montmorillonite for an efficient oxidation of mannose thioglycoside. Monatsh. Chem. 2013, 144, 969-973. [CrossRef]

8. Bindschädler, P.; Noti, C.; Castagnetti, E.; Seeberger, P.H. Synthesis of a Potential 10E4 Tetrasaccharide Antigen Involved in Scrapie Pathogenesis. Helv. Chim. Acta 2006, 89, 2591-2610. [CrossRef]

9. Dimitriou, E.; Miller, G.J. Exploring a glycosylation methodology for the synthesis of hydroxamate-modified alginate building blocks. Org. Biomol. Chem. 2019, 17, 9321-9335. [CrossRef] [PubMed]

10. Watt, J.A.; Williams, S.J. Rapid, iterative assembly of octyl $\alpha$-1,6-oligomannosides and their 6-deoxy equivalents. Org. Biomol. Chem. 2005, 3, 1982-1992. [CrossRef] [PubMed]

11. Van der Marel, G.; Codée, J.D.C. Carbohydrate Chemistry: Proven Synthetic Methods; CRC Press Taylor \& Francis Group: Boca Raton, FL, USA, 2014; Volume 2, pp. 175-182.

12. Oshitari, T.; Shibasaki, M.; Yoshizawa, T.; Tomita, M.; Takao, K.I.; Kobayashi, S. Synthesis of 2-O-(3-O-carbamoyl- $\alpha$-d-mannopyranosyl)-l-gulopyranose: Sugar moiety of antitumor antibiotic bleomycin. Tetrahedron 1997, 53, 10993-11006. [CrossRef]

13. Crich, D.; Smith, M.J. Solid-Phase Synthesis of $\beta$-Mannosides. J. Am. Chem. Soc. 2002, 124, 8867-8869. [CrossRef] [PubMed]

14. Van den Bos, E.J.L.; Dinkelaar, J.; Overkleeft, H.S.; van der Marel, G.A.J. Stereocontrolled Synthesis of $\beta$-D-Mannuronic Acid Esters: Synthesis of an Alginate Trisaccharide. J. Am. Chem. Soc. 2006, 128, 13066-13067. [CrossRef] [PubMed]

(C) 2020 by the authors. Licensee MDPI, Basel, Switzerland. This article is an open access article distributed under the terms and conditions of the Creative Commons Attribution (CC BY) license (http://creativecommons.org/licenses/by/4.0/). 


\title{
Communication
}

\section{8-Fluoro- $N$-2-isobutyryl-2'-deoxyguanosine: Synthesis and Reactivity}

\author{
Andrei Solodinin, James Helmkay, Samuel Ollivier and Hongbin Yan * \\ Department of Chemistry, Brock University, 1812 Sir Isaac Brock Way, St. Catharines, ON L2S 3A1, Canada; \\ as17lp@brocku.ca (A.S.); jh11hk@brocku.ca (J.H.); samuel.ollivier@ecole.ensicaen.fr (S.O.) \\ * Correspondence: tyan@brocku.ca; Tel.: +1-9056885550 (ext. 3545)
}

Academic Editor: Stefano D’Errico

Received: 18 February 2020; Accepted: 28 February 2020; Published: 6 March 2020

\begin{abstract}
O-Bis(tert-butyldimethylsilyl)-8-fluoro- $\mathrm{N}$-2-isobutyryl-2'-deoxyguanosine was synthesized from $3^{\prime}, 5^{\prime}$-O-bis(tert-butyldimethylsilyl)- $N$-2-isobutyryl-2'-deoxyguanosine by the treatment with $\mathrm{N}$-fluorobenzenesulfonimide. A similar fluorination reaction with $3^{\prime}, 5^{\prime}$-O-bis(tert-butyldimethylsilyl)$\mathrm{N}$-2-(N,N-dimethylformamidine)-2'-deoxyguanosine, however, failed to give the corresponding fluorinated product. It was found that 8-fluoro- $N$-2-isobutyryl-2'-deoxyguanosine is labile under acidic conditions, but sufficiently stable in dichloroacetic acid used in solid phase synthesis. Incorporation of 8-fluoro- $N$-2-isobutyryl-2'-deoxyguanosine into oligonucleotides through the phosphoramidite chemistry-based solid phase synthesis failed to give the desired products. Furthermore, treatment of 8-fluoro- $\mathrm{N}$-2-isobutyryl-2'-deoxyguanosine with aqueous ammonium hydroxide did not give 8-fluoro- $2^{\prime}$-deoxyguanosine, but led to the formation of a mixture consisting of 8-amino-N-2-isobutyryl-2'-deoxyguanosine and C8:5'-O-cyclo-2'-deoxyguanosine. Taken together, an alternative $\mathrm{N}$-protecting group and possibly modified solid phase synthetic cycle conditions will be required for the incorporation of 8-fluoro-2'-deoxyguanosine into oligonucleotides through the phosphoramidite chemistry-based solid phase synthesis.
\end{abstract}

Keywords: 8-Fluoro-2'-deoxyguanosine; ${ }^{19} \mathrm{~F}$ NMR spectroscopy; fluorination; solid phase synthesis; phosphoramidite

\section{Introduction}

Among the numerous modifications to nucleic acids, introduction of fluorine has attracted significant interest due to its small size and the ability for stereochemical control [1]. In this respect, presence of fluorine in the sugar residues allows for the control over sugar puckers, while introduction of fluorine to the nucleobases enables unique hydrogen bonding properties. Furthermore, presence of fluorine in nucleic acids presents an opportunity to study the structures of nucleic acids and the interaction involving these molecules by ${ }^{19} \mathrm{~F}$ NMR spectroscopy due to the abundance of ${ }^{19} \mathrm{~F}$ among its isotopes, large gyromagnetic ratio, and the sensitivity of ${ }^{19} \mathrm{~F}$ chemical shifts to structural changes [2]. We recently demonstrated that 5-fluoro-2'-deoxycytidine $\mathbf{1}$ (Figure 1 ) is a useful probe for the study of the B/Z-DNA handedness switch by ${ }^{19} \mathrm{~F}$ NMR [3]. 

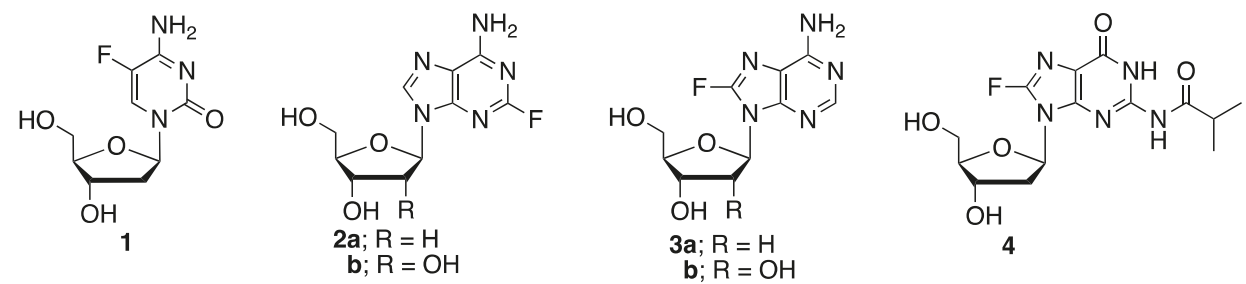

Figure 1. Nucleosides with fluorine modification in the nucleobase.

We are interested in expanding the scope of fluorine modification of nucleobases, especially to the guanine base in this respect, as $d(C G)$ repeats are the most widely studied sequences for the DNA handedness switch. We wish to describe the chemical synthesis of 8-fluoro- $\mathrm{N}$-isobutyryl-2'-deoxyguanosine 4 and its reactivity under the conditions for the assembly of oligonucleotides through the phosphoramidite chemistry-based solid phase.

\section{Results and Discussion}

Syntheses of adenine nucleosides, such as 2-fluoro-2'-deoxyadenosine 2a [4-7] and 2-fluoroadenosine $\mathbf{2} \mathbf{b}[6,8]$ have been demonstrated through different approaches. Introduction of fluorine to the C-8 position of purine nucleosides is more challenging, likely due to the instability of the resulting nucleosides. The F-C bond in 8 -F-rA $3 \mathbf{b}$ is labile under basic conditions. In this respect, basic conditions that are required for the removal of $\mathrm{N}$-acyl protecting groups can lead to defluorination. Thus, an early attempt to synthesize 8-fluoroadenosine $\mathbf{3 b}$ by the treatment of $2^{\prime}, 3^{\prime}, 5^{\prime}$-O-triacetyl-8-fluoroadenosine with methanolic ammonia [9] was later found not to give the desired 8-F-rA [10]. Enzymatic [11] or deprotection conditions under mild acidic conditions [12] allowed for the access of 8-F-rA. Fluorination of guanosine at the C-8 position was demonstrated by treatment with elemental fluorine [13]. This method, however, is inconvenient due to the difficulty in handling elemental fluorine. More recently, syntheses of protected 8-fluoro deoxyinosine, deoxyadenosine (which led to the formation of 8-fluoro-2'-deoxyadenosine 3 a after deprotection), and deoxyguanosine derivatives were demonstrated through metalation-electrophilic fluorination by the treatment of suitably protected purine nucleosides with lithium diisopropylamide (LDA) followed by $N$-fluorobenzenesulfonimide (NFSI) [14], all in low or moderate yields. In this chemistry, guanosine derivatives had to be protected at $\mathrm{O}-6$ position. We found that $\mathrm{N}$-2-isobutyryl protected, but not $\mathrm{N}$-2-formamidine protected, $2^{\prime}$-deoxyguanosine, compounds 6 and 8, respectively, can be fluorinated using this chemistry. Thus, 3',5'-O-bis(tert-butyldimethylsilyl)-N-2-isobutyryl-2'-deoxyguanosine 6 was subjected to metalation-electrophilic fluorination with LDA and NSFI to generate the corresponding 8-fluoro analog 7 in 30\% yield (Scheme 1), with recovery of 50\% the starting material 6 . A similar reaction with $3^{\prime}, 5^{\prime}$-O-bis(tert-butyldimethylsilyl)- $\mathrm{N}$-2- dimethylformamidine-2'-deoxyguanosine 8 failed to give the corresponding fluorinated product 9 . 


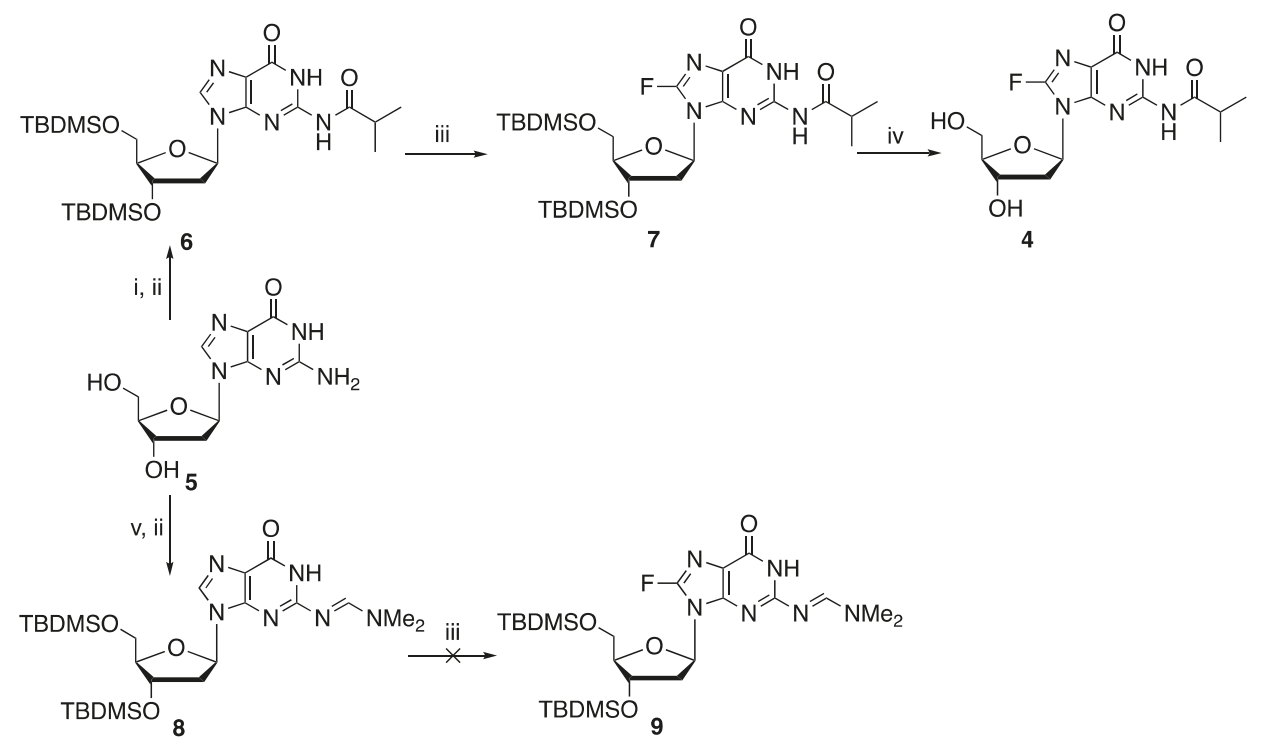

Scheme 1. Synthesis of 8-fluoro-deoxyguanosine derivatives. Reagents and conditions: (i). a. $\left(\mathrm{CH}_{3}\right)_{3} \mathrm{SiCl},\left(\left(\mathrm{CH}_{3}\right)_{2} \mathrm{CHCO}\right) \mathrm{O}, \mathrm{C}_{5} \mathrm{H}_{5} \mathrm{~N}$, r.t. 2.5 h; b. aq. $\mathrm{NH}_{3}, 0^{\circ} \mathrm{C}, 30 \mathrm{~min}$; (ii). TBDMSCl, DMF, r.t., $24 \mathrm{~h}$; (iii). a. LDA, toluene, $-78^{\circ} \mathrm{C}, 2 \mathrm{~h}$; b. NFSI; (iv). TBAF, THF, r.t., 1 h; (v). $\left(\mathrm{CH}_{3}\right)_{2} \mathrm{NCH}\left(\mathrm{OCH}_{3}\right)_{2}$, $\mathrm{MeOH}$, r.t., 2 d.

In order to introduce 8-fluoro-2'-deoxyguanosine into oligonucleotides through the phosphoramidite chemistry-based solid phase synthesis, the stability of 8-fluoro- $N$-2-isobutyryl $-2^{\prime}$-deoxyguanosine $\mathbf{1 2}$ in acidic conditions was investigated. This property is of importance as di- or trichloroacetic acid (DCA and TCA, respectively) is typically used for the removal of dimethoxytrityl (DMTr) group during the detritylation reaction. As such, 8-fluoro-2'-deoxyguanosine derivatives will need to be sufficiently stable under the acidic detritylation condition. Thus, experiments were conducted by ${ }^{19} \mathrm{~F}$ NMR spectroscopy to determine the stability of 8 -fluoro- $N$-isobutyryl-2'-deoxyguanosine 4 in acids of different $\mathrm{pKa}$.

As seen in Table 1, 8-fluoro- $N$-isobutyryl-2'-deoxyguanosine 4 is stable in 3\% benzoic acid and $80 \%$ acetic acid in methanol, and relatively stable in monochloroacetic acid (MCA), however, removal of the DMTr group with these acids is reversible. While 8-fluoro- $N$-isobutyryl-2'-deoxyguanosine 4 is relatively unstable in DCA and TCA, It was previously shown that DMTr removal can be effected by DCA and TCA in as little as $20 \mathrm{~s}$ [15], thus, DCA appears to be the most suited for the removal of DMTr groups in solid phase synthesis involving 8-fluoro- $N$-isobutyryl-2'-deoxyguanosine 4 . This nucleoside was subsequently protected with DMTr at $5^{\prime}-\mathrm{OH}$ (as in 10) and then transformed into the corresponding 3'-phosphoramidite $\mathbf{1 1}$ (Scheme 2).

Table 1. Half-lives of 8-fluoro- $N$-isobutyryl-2'-deoxyguanosine 4 under acidic conditions. (TCA: trichloroacetic acid; DCA: dichloroacetic acid; MCA: monochloroacetic acid).

\begin{tabular}{cc}
\hline Acid in MeOH & Half-Life (min) \\
\hline TCA 3\% & 10.5 \\
DCA 3\% $\% 5.2$ \\
MCA 3\% & 145.8 \\
Benzoic 3\% & Stable \\
Acetic 80\% & Stable \\
\hline
\end{tabular}




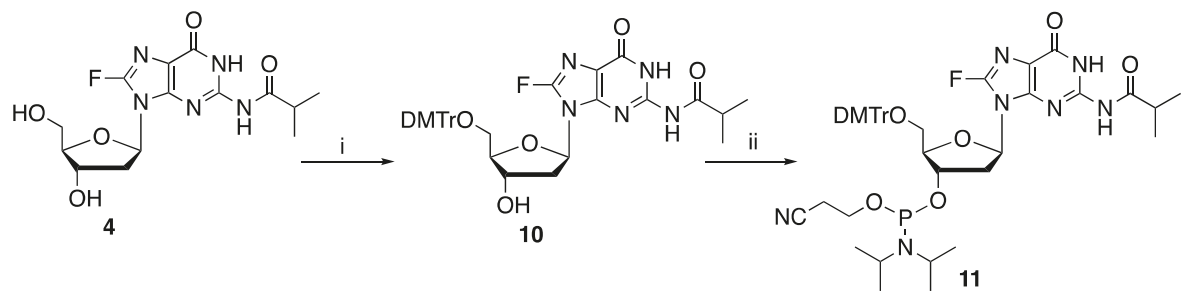

Scheme 2. Synthesis of phosphoramidite 11. Reagents and conditions: (i). DMTr- $\mathrm{Cl}_{1} \mathrm{C}_{5} \mathrm{H}_{5} \mathrm{~N}$, r.t., 30 min; (ii). $\mathrm{NCCH}_{2} \mathrm{CH}_{2} \mathrm{P}(\mathrm{Cl}) \mathrm{N}(i-\mathrm{Pr})_{2}, \mathrm{EtN}(i-\mathrm{Pr})_{2}$, r.t., $30 \mathrm{~min}$.

Solid phase syntheses were carried out using the ABI standard $1 \mu$ mol cycle conditions for the assembly of $d(C G)_{6}$ sequences where a single $d G$ was replaced with 8-fluoro-dG at each of the dG positions. The products were cleaved from the solid support and deprotected by incubation with concentrated aqueous ammonium hydroxide at $55^{\circ} \mathrm{C}$ overnight. All modified sequences were found by mass spectrometry to contain a major species with a mass of $3753 \mathrm{Da}$, which is 87 mass unit higher than the expected sequences $(3665 \mathrm{Da})$. The exact nature of the modification during solid phase synthesis that led to the formation of this higher mass species remains to be identified. It was found that the treatment of 8-fluoro- $\mathrm{N}$-2-isobutyryl-2'-deoxyguanosine $\mathbf{1 2}$ with the activator (5-ethylthio- $1 \mathrm{H}$-tetrazole) for coupling reactions or the oxidation solution containing aqueous iodine in pyridine, did not lead to the formation of displacement products 13 and 14, respectively, which, if reacted with 2,6-lutidine during the capping step, could generate the corresponding modified dG species 15 with the 87 extra mass units found in the oligonucleotides (Figure 2).

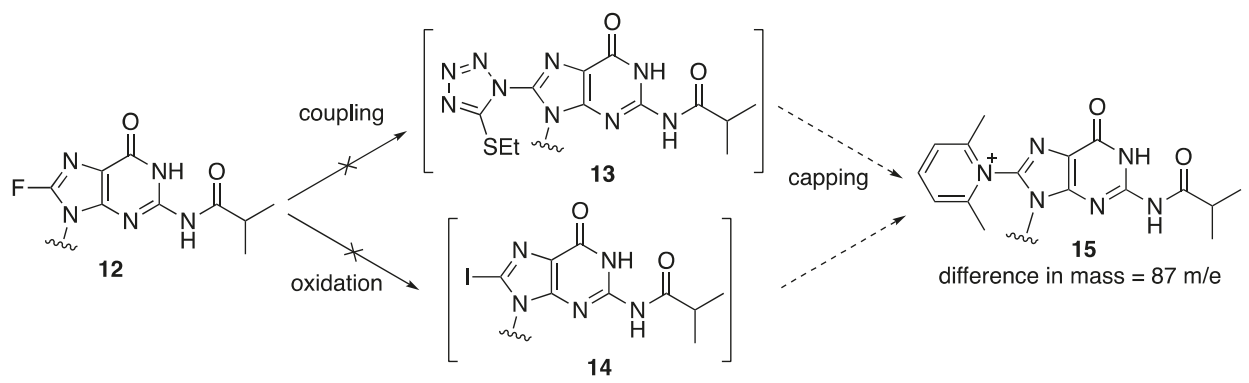

Figure 2. Hypothesized formation of a 2,6-lutidine-guanine adduct $\mathbf{1 5}$ during solid phase synthesis.

Finally, it was found that treatment of 8-fluoro- $N$-isobutyryl-2'-deoxyguanosine 4 (Scheme 3) with concentrated aqueous ammonium hydroxide at $55^{\circ} \mathrm{C}$ overnight, the typical conditions for the deprotection of $\mathrm{N}$-acyl groups, did not give the desired 8-fluoro- $2^{\prime}$-deoxyguanosine 18; instead, a mixture of 8-amino-2'-deoxyguanosine 16 and C8:5'-O-cyclo-2'-deoxyguanosine 17 was obtained in approximately a 2:1 ratio, as indicated by the reverse phase HPLC profile in Figure S28. 


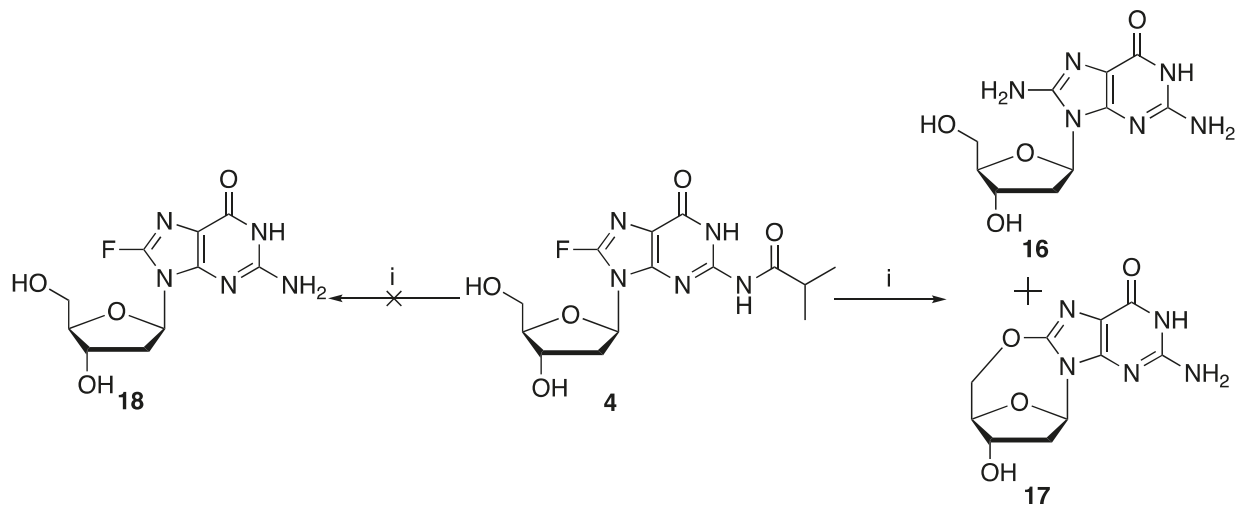

Scheme 3. Attempted deprotection of 8-fluoro- $N$-isobutyryl-2'-deoxyguanosine 4. (i). conc. aq. $\mathrm{NH}_{4} \mathrm{OH}, 55^{\circ} \mathrm{C}$, overnight.

Taken together, these results suggest that 8-fluoro- $N$-isobutyryl-2'-deoxyguanosine 4 is unsuitable for the introduction of 8-fluoro-2'-deoxyguanosine into oligonucleotides via the phosphoramidite chemistry-based solid phase synthesis. Alternative $N^{2}$-protecting groups, as well as modified solid phase synthesis conditions, will be required for successful incorporation of 8-fluoro-2' -deoxyguanosine into oligonucleotides.

\section{Materials and Methods}

${ }^{1} \mathrm{H}$ NMR spectra were measured at $400 \mathrm{MHz}$ with a Bruker Avance 400 Digital NMR spectrometer (Billerica, MA, USA). ${ }^{13} \mathrm{C},{ }^{31} \mathrm{P}$ and ${ }^{19} \mathrm{~F}$ NMR spectra were recorded at 100.6, 162.0 and $376.6 \mathrm{MHz}$ respectively, with the same spectrometer. Chemical shifts and coupling constants ( $J$ values) are given in ppm and Hz, respectively. Deuterated solvents were purchased from C/D/N Isotopes (Montreal, QC, Canada). EI (electron impact) and FAB (fast atom bombardment) mass spectra were obtained with a Thermo Scientific DFS mass spectrometer (Waltham, MA, USA); ESI (electrospray) spectra were measured with a Bruker HCT Plus ion-trap mass spectrometer. Desican silica gel (230-400 mesh) was used for column chromatography. Thin layer chromatography was performed on Silicycle F-254 silica TLC plates using the following solvent mixtures:

Solvent A: methanol-dichloromethane $(5: 95, v / v)$

Solvent B: methanol-dichloromethane $(20: 80, v / v)$

\subsection{Solvents and Chemicals}

Toluene was dried by heating under reflux over sodium in the presence of benzophenone for $4 \mathrm{~h}$ and then distilled under nitrogen. $N, N$-Diisopropylethylamine and pyridine were dried by heating under reflux over calcium hydride for $4 \mathrm{~h}$ and then distilled under nitrogen. $N, N$-Dimethylformamide was dried by heating at $60{ }^{\circ} \mathrm{C}$ over calcium hydride for $4 \mathrm{~h}$ and then distilled under vacuum. Dichloromethane was dried by heating under reflux over phosphorus pentoxide for $4 \mathrm{~h}$ and then distilled under nitrogen. All other reagents were purchased from Sigma-Aldrich or TCI America without further purification prior to use unless stated otherwise.

\subsection{3',5'-Bis(tert-butyldimethylsilyl)-N-isobutyryl-2'-deoxyguanosine (6)}

$N$-Isobutyryl-2'-deoxyguanosine 5 (3.50 g, $10.4 \mathrm{mmol})$, imidazole (4.66 g, $68.6 \mathrm{mmol})$ and tert-butyldimethylsilyl chloride $(6.90 \mathrm{~g}$, $45.7 \mathrm{mmol})$ were stirred in dry dimethylformamide $(30 \mathrm{~mL})$ for $5 \mathrm{~h}$. The resulting slurry was diluted with ethanol $(25 \mathrm{~mL})$ and stored at $-20{ }^{\circ} \mathrm{C}$ for $24 \mathrm{~h}$. White crystals were collected by vacuum filtration to give the title compound ( $4.93 \mathrm{~g}, 84 \%$ ). M.p. $102-104{ }^{\circ} \mathrm{C}$ (ethanol). 
$R_{\mathrm{f}}$ (system A): 0.38. HR-MS (EI) found 565.3099, $\mathrm{C}_{26} \mathrm{H}_{47} \mathrm{~N}_{5} \mathrm{O}_{5} \mathrm{Si}_{2}$ required 565.3116. $\delta_{\mathrm{H}}\left(\mathrm{CDCl}_{3}\right): 0.09$,

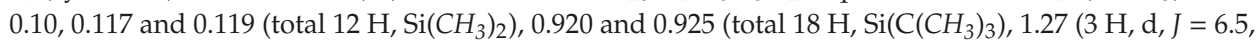
$i \mathrm{Bu}), 1.29(3 \mathrm{H}, \mathrm{d}, J=6.5), 2.37\left(1 \mathrm{H}, \mathrm{ddd}, J=3.8,6.0\right.$ and 10.0, $\left.\mathrm{H}-2^{\prime}\right), 2.47\left(1 \mathrm{H}, \mathrm{m}, \mathrm{H}-2^{\prime \prime}\right), 2.65(1 \mathrm{H}$, $\mathrm{CH}\left(\mathrm{CH}_{3}\right)_{2}$, septet, $\left.J=6.9\right), 3.78\left(2 \mathrm{H}, \mathrm{m}, \mathrm{H}-5^{\prime} / 5^{\prime \prime}\right), 3.99\left(1 \mathrm{H}, \mathrm{q}, J=3.4, \mathrm{H}-4^{\prime}\right), 4.58\left(1 \mathrm{H}, \mathrm{m}, \mathrm{H}-3^{\prime}\right), 6.23(1$ $\mathrm{H}, \mathrm{dd}, J=6.5$ and $\left.6.5, \mathrm{H}-1^{\prime}\right), 7.98(1 \mathrm{H}, \mathrm{s}, \mathrm{H}-8), 8.40(1 \mathrm{H}, \mathrm{s}, \mathrm{NH}), 12.00(1 \mathrm{H}, \mathrm{s}, \mathrm{NH}) . \delta_{\mathrm{C}}\left(\mathrm{CDCl}_{3}\right):-5.51$, $-5.38,-4.77,-4.68,18.0,18.4,18.95,19.01,25.7,26.0,36.6,41.4,62.8,71.8,83.5,88.0,121.5,136.8,147.3$, $147.8,155.5,178.1$.

\subsection{3',5'-Bis(tert-butyldimethylsilyl)-8-fluoro-N-isobutyryl-2'-deoxyguanosine (7)}

$3^{\prime}, 5^{\prime}$-Bis(tert-butyldimethylsilyl)- $N$-isobutyryl-2'-deoxyguanosine $6(4.00 \mathrm{~g}, 7.08 \mathrm{mmol})$ was co-evaporated with dry toluene $(3 \times 15 \mathrm{~mL})$ and dissolved in dry toluene $(80 \mathrm{~mL})$. After the mixture was cooled to $-78{ }^{\circ} \mathrm{C}$ (acetone-dry ice bath), $2.0 \mathrm{M}$ lithium diisopropylamide solution in THF/heptane/ethylbenzene $(17.7 \mathrm{~mL}, 35.4 \mathrm{mmol})$ was added slowly. After $2 \mathrm{~h}$, $\mathrm{N}$-fluorobenzenesulphonamide $(6.68 \mathrm{~g}, 21.2 \mathrm{mmol})$ was added and the mixture was stirred for $1.5 \mathrm{~h}$ at $-78{ }^{\circ} \mathrm{C}$ and then allowed to warm up to room temperature over $30 \mathrm{~min}$. Saturated aqueous ammonium chloride solution $(80 \mathrm{~mL})$ was added and the layers were separated. The aqueous layer was extracted with dichloromethane $(2 \times 40 \mathrm{~mL})$, and the combined organic layers were washed with saturated sodium bicarbonate solution $(100 \mathrm{~mL})$, dried over magnesium sulfate and concentrated under reduced pressure. The residue was purified by column chromatography on silica gel. The appropriate fractions, which were eluted with dichloromethane-methanol (99.3:0.7 v/v), were pooled and concentrated under reduced pressure to give the title compound as a pale yellow solid $(825 \mathrm{mg}$, $20 \%$ ). $R_{\mathrm{f}}$ (system A): 0.41. HR-MS (EI) found 583.3015, $\mathrm{C}_{26} \mathrm{H}_{46} \mathrm{~N}_{5} \mathrm{O}_{5} \mathrm{Si}_{2} \mathrm{~F}$ required 583.3022. $\delta_{\mathrm{H}}\left(\mathrm{CDCl}_{3}\right)$ : $0.04\left(3 \mathrm{H}, \mathrm{s}, \mathrm{Si}\left(\mathrm{CH}_{3}\right)_{2}\right), 0.06\left(3 \mathrm{H}, \mathrm{s}, \mathrm{Si}\left(\mathrm{CH}_{3}\right)_{2}\right), 0.13\left(6 \mathrm{H}, \mathrm{s}, \mathrm{Si}\left(\mathrm{CH}_{3}\right)_{2}\right), 0.89\left(9 \mathrm{H}, \mathrm{s}, \mathrm{Si}\left(\mathrm{C}_{(}\left(\mathrm{CH}_{3}\right)_{3}\right)_{2}\right), 0.93(9 \mathrm{H}$, $\left.\mathrm{s}, \mathrm{Si}\left(\mathrm{C}\left(\mathrm{CH}_{3}\right)_{3}\right)_{2}\right), 1.24\left(3 \mathrm{H}, \mathrm{d}, J=7.0, \mathrm{CH}\left(\mathrm{CH}_{3}\right)_{2}\right), 1.27\left(3 \mathrm{H}, \mathrm{d}, J=7.0, \mathrm{CH}\left(\mathrm{CH}_{3}\right)_{2}\right), 2.26(1 \mathrm{H}, \mathrm{ddd}, J=3.9$, 6.6 and 10.7, $\left.\mathrm{H}-2^{\prime}\right), 2.66\left(1 \mathrm{H}, \mathrm{CH}\left(\mathrm{CH}_{3}\right)_{2}\right.$, septet, $\left.J=6.9\right), 2.78\left(1 \mathrm{H}, \mathrm{m}, \mathrm{H}-2^{\prime \prime}\right), 3.71\left(2 \mathrm{H}, \mathrm{m}, \mathrm{H}-5^{\prime} / 5^{\prime \prime}\right), 3.89$ $\left(1 \mathrm{H}, \mathrm{m}, \mathrm{H}-4^{\prime}\right), 4.59\left(1 \mathrm{H}, \mathrm{m}, \mathrm{H}-3^{\prime}\right), 6.16\left(1 \mathrm{H}, \mathrm{dd}, J=6.8\right.$ and 6.8, $\left.\mathrm{H}-1^{\prime}\right), 8.69(1 \mathrm{H}, \mathrm{s}, \mathrm{NH}), 12.12(1 \mathrm{H}, \mathrm{s}$, $\mathrm{NH}) . \delta_{\mathrm{F}}\left(\mathrm{CDCl}_{3}\right):-101.3 . \delta_{\mathrm{C}}\left(\mathrm{CDCl}_{3}\right):-5.5,-5.4,-4.8,-4.7,18.0,18.4,18.8,19.1,25.8,25.9,36.5,37.9$, $62.7,71.7,82.3,87.7,114.8\left(\mathrm{~d}, J_{\mathrm{C}, \mathrm{F}}=13.9\right), 146.7\left(\mathrm{~d}, J_{\mathrm{C}, \mathrm{F}}=3.3\right), 147.7\left(\mathrm{~d}, J_{\mathrm{C}, \mathrm{F}}=2.7\right), 149.6\left(\mathrm{~d}, J_{\mathrm{C}, \mathrm{F}}=251.1\right)$, $154.8,178.5$.

\subsection{8-Fluoro-N-isobutyryl-2'-deoxyguanosine (4)}

$3^{\prime}, 5^{\prime}$-Bis(tert-butyldimethylsilyl)-8-fluoro- $N$-isobutyryl-2'-deoxyguanosine 7 ( $\left.350 \mathrm{mg}, 0.60 \mathrm{mmol}\right)$ and tetra- $n$-butylammonium fluoride $(391 \mathrm{mg}, 1.5 \mathrm{mmol})$ were stirred in tetrahydrofuran $(12 \mathrm{~mL})$ for $1 \mathrm{~h}$ at r.t., followed by addition of warm water $\left(50{ }^{\circ} \mathrm{C}\right)$ until all salts dissolved. The product crystalized from water to give $127 \mathrm{mg}(60 \%)$ of the title compound as white crystals. M.p.: decomposed at $183-185^{\circ} \mathrm{C}$ (water). $R_{\mathrm{f}}$ (system B): 0.72. HR-MS (EI) found $335.1220, \mathrm{C}_{14} \mathrm{H}_{18} \mathrm{~N}_{5} \mathrm{O}_{5} \mathrm{~F}$ requires 355.1292 . $\delta_{\mathrm{H}}\left(\mathrm{DMSO}^{\mathrm{d}} \mathrm{d}_{6}\right): 1.13\left(6 \mathrm{H}, \mathrm{d}, J=6.6, \mathrm{CH}\left(\mathrm{CH}_{3}\right)_{2}\right), 2.24\left(1 \mathrm{H}, \mathrm{ddd}, J=3.8,6.5\right.$ and $\left.10.2, \mathrm{H}-2^{\prime}\right), 2.76(2 \mathrm{H}, \mathrm{m}$, $\mathrm{H}-2^{\prime \prime}$ and $\left.\mathrm{CH}\left(\mathrm{CH}_{3}\right)_{2}\right), 3.79\left(1 \mathrm{H}, \mathrm{m}, \mathrm{H}-4^{\prime}\right), 4.37\left(1 \mathrm{H}, \mathrm{m}, \mathrm{H}-3^{\prime}\right), 4.84\left(1 \mathrm{H}, \mathrm{t}, J=5.6,5^{\prime}-\mathrm{OH}, \mathrm{ex}\right), 5.35(1$ $\left.\mathrm{H}, \mathrm{d}, J=4.0,3^{\prime}-\mathrm{OH}, \mathrm{ex}\right), 6.17\left(1 \mathrm{H}, \mathrm{t}, J=6.9, \mathrm{H}^{\prime} 1^{\prime}\right), 11.68(1 \mathrm{H}, \mathrm{s}, \mathrm{NH}, \mathrm{ex}), 12.17(1 \mathrm{H}, \mathrm{s}, \mathrm{NH}, \mathrm{ex}) . \delta_{\mathrm{C}}$ $\left(\right.$ DMSO-d $\left._{6}\right): 14.0,19.3,35.3,37.5,62.0,70.7,82.8,88.2,113.9\left(\mathrm{~d}, J_{\mathrm{C}, \mathrm{F}}=13.1\right), 147.5\left(\mathrm{~d}, J_{\mathrm{C}, \mathrm{F}}=3.2\right), 148.9(\mathrm{~d}$, $\left.J_{\mathrm{C}, \mathrm{F}}=2.6\right), 149.5\left(\mathrm{~d}, J_{\mathrm{C}, \mathrm{F}}=247.6\right), 154.4\left(\mathrm{~d}, J_{\mathrm{C}, \mathrm{F}}=2.1\right), 180.6 . \delta_{\mathrm{F}}\left(\mathrm{DMSO}-\mathrm{d}_{6}\right):-102.9$.

\subsection{5'-(4,4'-Dimethoxytrityl)-8-fluoro-N-isobutyryl-2'-deoxyguanosine (10)}

8-Fluoro- $\mathrm{N}$-isobutyryl-2'-deoxyguanosine $4(0.50 \mathrm{~g}$, $1.4 \mathrm{mmol})$ was co-evaporated with dry pyridine $(3 \times 10 \mathrm{~mL})$ and dissolved in dry pyridine $(5 \mathrm{~mL})$, followed by addition of $4,4^{\prime}$-dimethoxytrityl chloride $(0.72 \mathrm{~g}, 2.1 \mathrm{mmol})$. After $30 \mathrm{~min}$, the reaction was quenched with a triethylamine/ethanol $(1: 1 \mathrm{v} / \mathrm{v})$ mixture $(1 \mathrm{~mL})$. The products were diluted with dichloromethane $(50 \mathrm{~mL})$ and extracted with saturated aqueous sodium hydrogen carbonate $(50 \mathrm{~mL})$. The aqueous layer was back-extracted with dichloromethane $(30 \mathrm{~mL})$ and the combined organic layers were dried $\left(\mathrm{MgSO}_{4}\right)$ and evaporated under reduced pressure. The oily residue was purified by column chromatography on silica gel. The 
appropriate fractions, which were eluted with dichloromethane-ethanol-triethylamine (98.2:1.5:0.3 $v / v / v)$, were pooled and concentrated under reduced pressure to give the title compound as a colorless glass $(850 \mathrm{mg}, 92 \%) . R_{\mathrm{f}}$ (system A): 0.27. MS (ESI) found $658.2\left(\mathrm{M}-\mathrm{H}^{+}\right), \mathrm{C}_{35} \mathrm{H}_{37} \mathrm{FN}_{5} \mathrm{O}_{7}{ }^{+}$required 658.2677. $\delta_{\mathrm{H}}\left(\mathrm{CDCl}_{3}\right): 0.98(3 \mathrm{H}, \mathrm{d}, J=6.7), 1.07(3 \mathrm{H}, \mathrm{d}, J=7.0), 2.27\left(1 \mathrm{H}, \mathrm{CH}\left(\mathrm{CH}_{3}\right)_{2}, \mathrm{~m}\right), 2.34(1 \mathrm{H}$, $\mathrm{ddd}, J=4.2,6.2$ and 10.6, $\left.\mathrm{H}-2^{\prime}\right), 3.00\left(1 \mathrm{H}, \mathrm{m}, \mathrm{H}-2^{\prime \prime}\right), 3.24\left(1 \mathrm{H}, \mathrm{dd}, J=5.2\right.$ and $\left.10.3, \mathrm{H}-5^{\prime}\right), 3.36(1 \mathrm{H}, \mathrm{dd}$, $J=3.7$ and $\left.10.3, \mathrm{H}-5^{\prime \prime}\right), 3.74$ and $3.75\left(6 \mathrm{H},\left(\mathrm{OCH}_{3}\right)_{2}\right), 4.09\left(1 \mathrm{H}, \mathrm{ddd}, J=4.1,4.1\right.$ and $\left.8.5, \mathrm{H}-4^{\prime}\right), 4.82(1$ $\left.\mathrm{H}, \mathrm{m}, \mathrm{H}-3^{\prime}\right), 6.14\left(1 \mathrm{H}, \mathrm{dd}, J=6.2\right.$ and $\left.6.2, \mathrm{H}^{\prime} \mathbf{1}^{\prime}\right), 6.74(3 \mathrm{H}, \mathrm{d}, J=3.1), 6.77(3 \mathrm{H}, \mathrm{d}, J=3.1), 7.14-7.23$ $(3 \mathrm{H}, \mathrm{m}), 7.30$ and $7.32(4 \mathrm{H}), 7.44(2 \mathrm{H}, \mathrm{dd}, J=1.5$ and 8.3$) . \delta_{\mathrm{F}}\left(\mathrm{CDCl}_{3}\right):-103.7 . \delta_{\mathrm{C}}\left(\mathrm{CDCl}_{3}\right): 18.75,18.77$, $36.0,36.2,55.2,63.9,71.4,82.8,86.1,86.3,113.1,115.0,126.9,127.8,128.1,129.96,130.0,135.9,136.1$, $144.9,146.9,147.8,148.6,158.5,179.4$.

\subsection{5'-(4,4'-Dimethoxytrityl)-8-fluoro-N-isobutyryl-2'-deoxyguanosine-3'-(2-cyanoethyl)-N,N} -diisopropylphosphoramidite (11)

5'-(4,4'-Dimethoxytrityl)-8-fluoro- $N$-isobutyryl-2'-deoxyguanosine 10 (1.00 g, $1.52 \mathrm{mmol})$ was co-evaporated with dry toluene $(3 \times 10 \mathrm{~mL})$ and then dissolved in dry dichloromethane $(20 \mathrm{~mL})$, followed by addition of dry $\mathrm{N}, \mathrm{N}$-diisopropylethylamine $(1.0 \mathrm{~mL}, 5.7 \mathrm{mmol})$ and (2-cyanoethyl)- $N, N$-diisopropyl phosphochloridite $(0.72 \mathrm{~g}, 3.0 \mathrm{mmol})$. After the reaction mixture was stirred for $30 \mathrm{~min}$, triethylamine $(1 \mathrm{~mL})$ was added and products were concentrated under reduced pressure. The residue was purified by column chromatography on silica gel. The appropriate fractions, which were eluted with hexane-acetone-triethylamine (70:28:2 v/v/v), were pooled and concentrated under reduced pressure. The resulting oil was dissolved in dichloromethane $(2 \mathrm{~mL})$ and added dropwise to pentane $(20 \mathrm{~mL})$ at $-40{ }^{\circ} \mathrm{C}$ under stirring. The cloudy suspension was centrifuged for $20 \mathrm{~min}$ and the supernatant was decanted. The white solid was collected and dried to give the title phosphoramidite $(0.57 \mathrm{~g}, 44 \%)$. HR-MS (FAB) found $858.3787\left([\mathrm{M}+\mathrm{H}]^{+}\right), \mathrm{C}_{44} \mathrm{H}_{54} \mathrm{FN}_{7} \mathrm{O}_{8} \mathrm{P}^{+}$required 858.3755. $\delta_{\mathrm{H}}\left(\mathrm{CDCl}_{3}\right)$ include the following signals: 2.45-2.56 (1 H, m, H-2'), 3.12-3.51 (3 H, m, H-2" , H-5', and $\left.\mathrm{H}-5^{\prime \prime}\right), 3.774,3.777,3.782$ and $3.787(6 \mathrm{H},-\mathrm{OMe}), 4.21-4.29\left(1 \mathrm{H}, \mathrm{m}, \mathrm{H}-4^{\prime}\right), 4.77-4.89\left(1 \mathrm{H}, \mathrm{m}, \mathrm{H}-3^{\prime}\right), 6.19\left(1 \mathrm{H}, \mathrm{m}, \mathrm{H}-1^{\prime}\right), 6.75-6.79$ $(4 \mathrm{H}, \mathrm{m}) . \delta_{\mathrm{F}}\left(\mathrm{CDCl}_{3}\right):-106.27$ and $-104.28 . \delta_{\mathrm{P}}\left(\mathrm{CDCl}_{3}\right): 147.78$ and 147.96.

\subsection{Treatment of 8-Fluoro-N-isobutyryl-2'-deoxyguanosine under Ammonolysis Conditions}

8-Fluoro- $N$-isobutyryl-2'-deoxyguanosine $(4 \mathrm{mg})$ was incubated with concentrated aqueous ammonium hydroxide $(1.0 \mathrm{~mL})$ at $55^{\circ} \mathrm{C}$ for $16 \mathrm{~h}$. Upon cooling the products were lyophilized. The residue was purified by column chromatography using C18-reverse phase matrix $(1 \times 15 \mathrm{~cm})$ on a BioRad DuoFlow FPLC system. The column was eluted with acetonitrile-water (0:100 to 30:70 v/v) in a linear gradient over $60 \mathrm{~min}$. Eluants were collected in $1.0 \mathrm{~mL}$ fractions and lyophilized.

\subsection{Oligonucleotide Synthesis}

Oligonucleotides were synthesized using an ABI 3400 DNA synthesizer (Waltham, MA, USA) under the standard $1 \mu \mathrm{mol}$ cycle conditions. Phosphoramidites were prepared as $100 \mathrm{mM}$ solutions in dry acetonitrile. A solution of 5-(ethylthio)- $1 H$-tetrazole ( $250 \mathrm{mM}$ in dry acetonitrile) was used as the activator, and coupling reaction time was set at $60 \mathrm{~s}$. Detritylation was effected by delivering dichloroacetic acid (3\% in dichloromethane) to reaction columns for $110 \mathrm{~s}$. After solid phase synthesis was complete, the products were cleaved from solid support and deprotected by incubation with ammonium hydroxide at $55^{\circ} \mathrm{C}$ for $24 \mathrm{~h}$ and then lyophilized.

\section{Conclusions}

$3^{\prime}, 5^{\prime}$-O-Bis(tert-butyldimethylsilyl)-8-fluoro- $N$-2-isobutyryl-2'-deoxyguanosine was synthesized by treating $3^{\prime}, 5^{\prime}$-O-bis(tert-butyldimethylsilyl)- $N$-2-isobutyryl-2'-deoxyguanosine with LDA and $\mathrm{N}$-fluorobenzenesulfonimide. Subsequent deprotection afforded 8-fluoro- $\mathrm{N}$-2-isobutyryl-2'-deoxyguanosine. The latter compound was found to be sufficiently stable in $3 \%$ dichloroacetic acid, however, incorporation of the corresponding phosphoramidite into $d(C G)_{6}$ sequences did not lead to the 
formation of the desired 8-fluoro-2'-deoxyguanosine modified oligonucleotides. Treatment of 8 -fluoro- $N$-2-isobutyryl-2'-deoxyguanosine under ammonolysis conditions led to the formation of a mixture of 8-amino-2'-deoxyguanosine and C8:5'-O-cyclo-2'-deoxyguanosine. Future work will explore protecting groups for the exocyclic amine that are readily removable under conditions that do not lead to modification of this nucleoside. Furthermore, cycle conditions for solid phase synthesis need to be modified in order to successfully incorporate 8-fluoro-2'-deoxyguanosine.

Supplementary Materials: The supplementary materials are available online.

Author Contributions: Conceptualization, A.S. and H.Y.; methodology, A.S., J.H., S.O. and H.Y.; experiment, A.S., J.H. and S.O.; writing, review and editing, A.S., J.H., S.O. and H.Y.; supervision, H.Y. All authors have read and agreed to the published version of the manuscript.

Funding: This research was funded by the Natural Sciences and Engineering Research Council of Canada.

Conflicts of Interest: The authors declare no conflict of interest. The funders had no role in the design of the study; in the collection, analyses, or interpretation of data; in the writing of the manuscript, or in the decision to publish the results.

\section{References}

1. Guo, F.; Li, Q.; Zhou, C. Synthesis and biological applications of fluoro-modified nucleic acids. Org. Biomol. Chem. 2017, 15, 9552-9565. [CrossRef] [PubMed]

2. Chen, H.; Viel, S.; Ziarelli, F.; Peng, L. ${ }^{19}$ F NMR: A valuable tool for studying biological events. Chem. Soc. Rev. 2013, 42, 7971-7982. [CrossRef] [PubMed]

3. Solodinin, A.; Gautrais, A.; Ollivier, S.; Yan, H. 5-Fluoro-2'-deoxycytidine as a probe for the study of B/Z-DNA transition by ${ }^{19} \mathrm{~F}$ NMR spectroscopy. Acs Omega 2019, 4, 19716-19722. [CrossRef]

4. Ye, S.; Rezende, M.M.; Deng, W.P.; Kirk, K.L. Convenient synthesis of 2'-deoxy-2-fluoroadenosine from 2-fluoroadenine. NucleosidesNucleotides Nucleic Acids 2003, 22, 1899-1905. [CrossRef]

5. Nóbile, M.; Terreni, M.; Lewkowicz, E.; Iribarren, A.M. Aeromonas hydrophila strains as biocatalysts for transglycosylation. Biocatal. Biotransform. 2010, 28, 395-402. [CrossRef]

6. Zhou, X.; Szeker, K.; Jiao, L.-Y.; Oestreich, M.; Mikhailopulo, I.A.; Neubauer, P. Synthesis of 2,6-dihalogenated purine nucleosides by thermostable nucleoside phosphorylases. Adv. Synth. Catal. 2015, 357, 1237-1244. [CrossRef]

7. Pérez, E.; Sánchez-Murcia, P.A.; Jordaan, J.; Blanco, M.D.; Mancheño, J.M.; Gago, F.; Fernández-Lucas, J. Enzymatic synthesis of therapeutic nucleosides using a highly versatile purine nucleoside 2 '-deoxyribosyl transferase from Trypanosoma brucei. ChemCatChem 2018, 10, 4406-4416. [CrossRef]

8. Krolikiewicz, K.; Vorbrüggen, H. The synthesis of 2-fluoropurine nucleosides. Nucleosides Nucleotides 1994, 13, 673-678. [CrossRef]

9. Ikehara, M.; Yamada, S. Studies of nucleosides and nucleotides. XLIX. Synthesis of 8-fluoroadenosine. Chem. Pharm. Bull. 1971, 19, 104-109. [CrossRef]

10. Kobayashi, Y.; Kumadaki, I.; Ohsawa, A.; Murakami, S.-I. Synthesis of 2' ', 3', 5' -tris-O-acetyl-8-fluoroadenosine. J. Chem. Soc., Chem. Commun. 1976, 12, 430-431. [CrossRef]

11. Barrio, J.R.; Namavari, M.; Keen, R.E.; Satyamurthy, N. The elusive 8-fluoroadenosine. Tetrahedron Lett. 1998, 39, 7231-7234. [CrossRef]

12. Butora, G.; Schmitt, C.; Levorse, D.A.; Streckfuss, E.; Doss, G.A.; MacCoss, M. The elusive 8-fluoroadenosine: A simple non-enzymatic synthesis and characterization. Tetrahedron 2007, 63, 3782-3789. [CrossRef]

13. Barrio, J.R.; Namavari, M.; Phelps, M.E.; Satyamurthy, N. Regioselective fluorination of substituted guanines with dilute F2: A facile entry to 8-fluoroguanine derivatives. J. Org. Chem. 1996, 61, 6084-6085. [CrossRef] [PubMed]

14. Ghosh, A.K.; Lagisetty, P.; Zajc, B. Direct synthesis of 8-fluoro purine nucleosides via metalation-fluorination. J. Org. Chem. 2007, 72, 8222-8226. [CrossRef] [PubMed] 
15. Tram, K.; Sangvi, Y.; Yan, H. Further studies on the detritylation in solid phase oligodeoxyribonucleotide synthesis. Nucleoside Nucleotides Nucleic Acids 2011, 30, 12-19. [CrossRef] [PubMed]

Sample Availability: Samples of the compounds are not available from the authors.

(C) 2020 by the authors. Licensee MDPI, Basel, Switzerland. This article is an open access article distributed under the terms and conditions of the Creative Commons Attribution (CC BY) license (http://creativecommons.org/licenses/by/4.0/). 



\title{
Communication
}

\section{Unexpected Seven-Membered Ring Formation for Muraymycin-Type Nucleoside-Peptide Antibiotics}

\author{
Kristin Leyerer, Stefan Koppermann and Christian Ducho * \\ Department of Pharmacy, Pharmaceutical and Medicinal Chemistry, Saarland University, Campus C2 3, \\ 66123 Saarbrücken, Germany; kristinleyerer@gmail.com (K.L.); stefan.koppermann@uni-saarland.de (S.K.) \\ * Correspondence: christian.ducho@uni-saarland.de; Tel.: +49-(0)681-302-70343
}

Received: 11 February 2020; Accepted: 23 March 2020; Published: 26 March 2020

\begin{abstract}
Naturally occurring nucleoside-peptide antibiotics such as muraymycins or caprazamycins are of major interest for the development of novel antibacterial agents. However, the synthesis of new analogues of these natural products for structure-activity relationship (SAR) studies is challenging. In our synthetic efforts towards a muraymycin-derived nucleoside building block suitable for attachment to a solid support, we came across an interesting side product. This compound resulted from an undesired Fmoc deprotection with subsequent cyclization, thus furnishing a remarkable caprazamycin-like seven-membered diazepanone ring.
\end{abstract}

Keywords: muraymycins; caprazamycins; nucleosides; uridine; cyclization; seven-membered rings

\section{Introduction}

Emerging bacterial strains that are resistant to antibiotics are a severe threat in healthcare [1-3]. To address this problem, novel antibacterial agents with previously unexploited modes of action are urgently needed [4]. A promising class that meets this requirement are uridine-derived nucleosidepeptide antibiotics that interfere with bacterial cell wall biosynthesis [5-7]. They inhibit MraY, an enzyme that catalyzes a membrane-associated step in the intracellular part of peptidoglycan formation [8-13]. Among this structurally diverse class, our research focusses mainly on the subclasses of muraymycins [14,15] and caprazamycins [16-22] (Figure 1). For muraymycins, a co-crystal structure in complex with MraY has been reported, enabling deeper insights into the inhibitor-target interaction [23-25]. However, experimental structure-activity relationship (SAR) studies are still crucial due to the pronounced conformational plasticity of MraY, and have therefore been carried out extensively as exemplified by the according work on muraymycins [26-35].

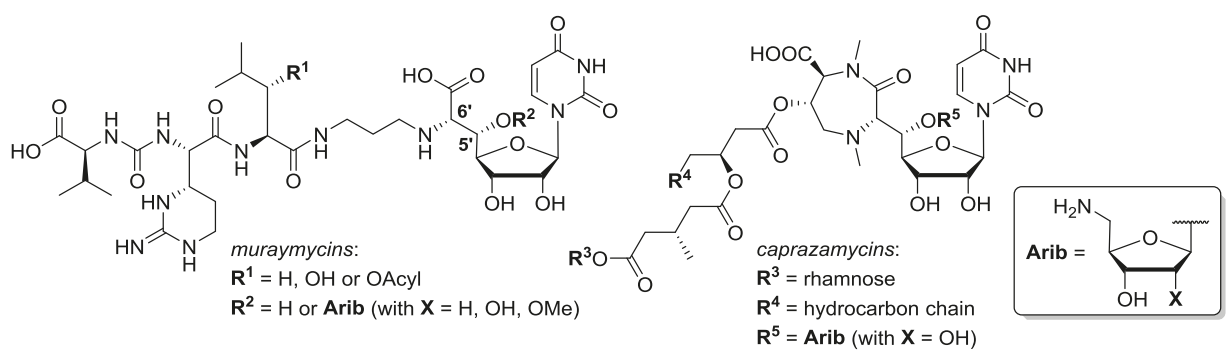

Figure 1. Structures of the nucleoside-peptide antibiotics muraymycins and caprazamycins.

In contrast to previously reported solution-phase syntheses of muraymycin derivatives $[28,30,31]$, we have recently described a solid phase-supported approach for the preparation of structurally 
simplified muraymycin analogues [36]. This novel strategy was based on the stepwise construction of the muraymycin peptide unit on the solid support. As part of our initial studies on this approach, we had also investigated a potential attachment of the muraymycin nucleoside unit (or an analogue thereof) to the solid phase. Hence, we had envisioned to prepare uridine-derived building block 5 (see Scheme 2) that could then be connected to the solid phase. The design of 5 was based on our previously reported strategy to simplify the muraymycin core structure by omission of the $5^{\prime}$-substituent (" 5 '-deoxy" analogues) [30,33,35-38]. Carboxylic acid 5 was intended to be attached to a trityl resin by formation of a trityl ester. In order to then apply standard solid-phase protocols for the assembly of the peptide unit, we chose Fmoc as protecting group for the terminal amino group of the linker moiety. For the preparation of 5, we intended to selectively cleave the tert-butyl ester in the 7 '-position of precursor 4 (Schemes 1 and 2). Studies on this particular transformation have furnished the unexpected side reaction reported in this work.

\section{Results}

The synthesis of the fully protected uridine-derived precursor building block 4 involved protocols that were previously reported by our group. Thus, uridine $\mathbf{1}$ was transformed into the protected nucleosyl amino acid 2 using an established five-step route (Scheme 1) [30,37,38]. This was followed by reductive amination of 2 with Fmoc-protected aldehyde 3 [36]. The reductive amination step was carried out in a similar way as with other Cbz-protected aldehydes as previously reported [30] (i.e., using amberlyst as acidic activator and sodium triacetoxyborohydride as reducing agent). The resultant product 4 was obtained in $71 \%$ yield (Scheme 1 ).

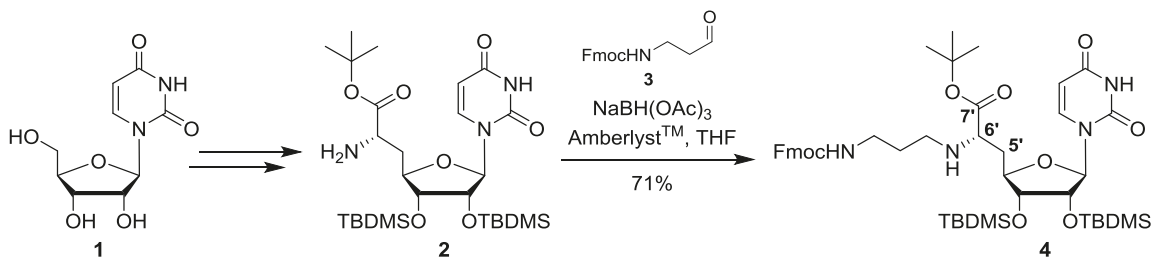

Scheme 1. Synthesis of protected uridine-derived precursor building block 4 .

For the envisioned selective deprotection of the $7^{\prime}$-carboxylate of 4 , we needed a method that would cleave the tert-butyl ester but leave the tert-butyldimethylsilyl (TBDMS) groups intact. We therefore studied the mild acidic cleavage of the tert-butyl ester of 4-as previously reported by us for similar transformations [39] - in order to potentially obtain 5 (Scheme 2). In first attempts, the reaction was carried out by stirring a solution of 4 in toluene in the presence of silica at reflux temperature (i.e., $111^{\circ} \mathrm{C}$ (Table 1, entries 1-3)). The conversion of 4 was monitored by thin layer chromatography (TLC). Surprisingly, a seven-membered diazepanone ring was formed to give main product 6 (without the Fmoc protecting group) in a yield of $41 \%$ (Table 1, entry 1). This was unexpected, as the Fmoc group usually requires basic conditions for its cleavage. We speculated that, under the applied reaction conditions (high temperature, extended reaction period of 5 days), the secondary amine at the $6^{\prime}$-position of 4 might have been sufficiently basic to mediate Fmoc deprotection. The resultant primary amine then probably attacked the $7^{\prime}$-tert-butyl ester of 4 , thus leading to ring formation (proposed mechanism not shown). By significantly decreasing the reaction period, the yield of side product 6 even increased to $68 \%$ (after 1.5 days, Table 1, entry 2 ) and $76 \%$ (after 5 h, entry 3 ), respectively. This demonstrated that 6 was indeed the main product of this transformation at elevated temperatures. Variation of the temperature then revealed that the desired product 5 might have been formed at lower temperatures, but only in small amounts. Target compound 5 was obtained when the reaction mixture was stirred at $80^{\circ} \mathrm{C}$ for 1 day and then at room temperature (rt) for further 2 days, furnishing a moderate yield of $48 \%$ of 5 (Table 1, entry 4). Further attempts to repeat this reaction towards 5 
and possibly improve its yield only gave worse results (i.e., lower yields with significant amounts of unidentified impurities). We also explored other conditions to selectively cleave the tert-butyl ester, mainly the treatment of 4 with TFA (Table 1, entries 5-7) or with pig liver esterase (PLE, entry 8), but none of these experiments afforded satisfying conversions to the desired carboxylic acid 5 .

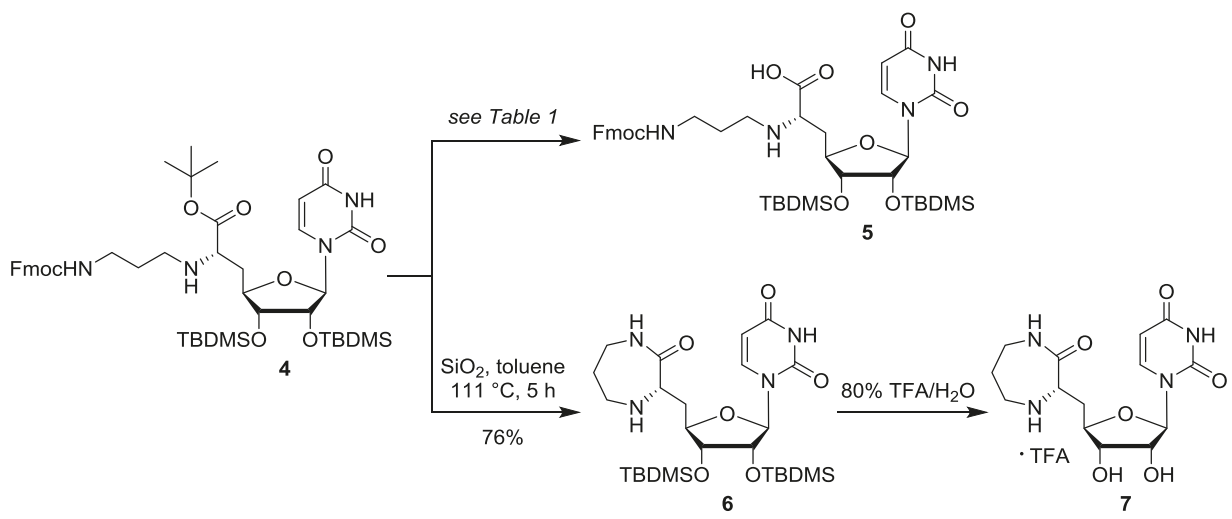

Scheme 2. Attempted deprotection of 4 towards 5, yielding diazepanone 6 as major product instead.

Table 1. Investigated conditions for the attempted reaction of 4 to 5 (see Scheme 2).

\begin{tabular}{|c|c|c|c|c|}
\hline \# & Reagents & Temperature & Reaction Period & Product \\
\hline 1 & $\mathrm{SiO}_{2}$, toluene & $111^{\circ} \mathrm{C}$ (reflux) & 5 days & $41 \% 6$ \\
\hline 2 & $\mathrm{SiO}_{2}$, toluene & $111^{\circ} \mathrm{C}$ (reflux) & 1.5 days & $68 \% 6$ \\
\hline 3 & $\mathrm{SiO}_{2}$, toluene & $111^{\circ} \mathrm{C}$ (reflux) & $5 \mathrm{~h}$ & $76 \% 6$ \\
\hline 4 & $\mathrm{SiO}_{2}$, toluene & $80^{\circ} \mathrm{C}$, then $\mathrm{rt}$ & 3 days & $48 \% 5$ \\
\hline 5 & $80 \% \mathrm{TFA} / \mathrm{CH}_{2} \mathrm{Cl}_{2}$ & $\mathrm{rt}$ & $2 \mathrm{~h}$ & $\begin{array}{l}\text { partial TBDMS } \\
\text { deprotection }\end{array}$ \\
\hline 6 & $80 \%$ TFA $/ \mathrm{CH}_{2} \mathrm{Cl}_{2}$ & $\mathrm{rt}$ & $1 \mathrm{~h}$ & $\begin{array}{c}16 \% 5 \\
\left(24 \% \text { brsm }^{1}\right)\end{array}$ \\
\hline 7 & $50 \% \mathrm{TFA} / \mathrm{CH}_{2} \mathrm{Cl}_{2}$ & $\mathrm{rt}$ & $2.5 \mathrm{~h}$ & full TBDMS deprotection \\
\hline 8 & $\begin{array}{c}\text { PLE, phosphate buffer (pH 7.5, } \\
0.1 \mathrm{M}), \mathrm{DMF}\end{array}$ & $\mathrm{rt}$ & 2 days & no reaction \\
\hline
\end{tabular}

${ }^{1}$ brsm $=$ based on recovered starting material.

Since no reaction conditions were identified that gave the desired uridine-derived building block 5 in robust, reproducible and satisfying yields, this strategy for the solid phase-supported synthesis of muraymycin analogues was discarded, and our reported route (vide supra) was established instead [36]. The obtained diazepanone side product 6 represented an interesting structure as it strongly resembles the core structure ("caprazol") of caprazamycin antibiotics (cf. Figure 1). We therefore intended to evaluate a deprotected derivative of $\mathbf{6}$ for its biological activity. Uridine-derived diazepanone $\mathbf{6}$ was globally deprotected using $80 \%$ aqueous TFA for acidic desilylation (Scheme 2). The resultant fully deprotected caprazol analogue 7 was purified by semipreparative HPLC. In the ${ }^{1} \mathrm{H}$ NMR spectrum of the obtained product, two sets of signals for the H-5 and H-6 protons of the nucleobase were observed, hinting at a uracil-derived impurity that could not be separated from target compound 7 and that could not be identified. However, the amount of this impurity could be estimated from the ${ }^{1} \mathrm{H}$ NMR to be $\sim 30 \%$ based on the uracil-associated signals. We therefore decided to test this mixture of 7 and the unidentified impurity for its potential to inhibit the bacterial target protein MraY, using an established in vitro assay for MraY activity $[32,33,40]$. It was found that the $\mathrm{IC}_{50}$ value of the mixture containing caprazol analogue 7 was outside of the relevant range $\left(\mathrm{IC}_{50}>50 \mu \mathrm{g} / \mathrm{mL}\right)$, thus demonstrating that 7 did not inhibit MraY to a relevant extent (also see Supplementary Materials, Figure S1, for measured data). 


\section{Discussion}

The encountered side reaction from precursor 4 to diazepanone 6 is highly interesting as the construction of the diazepanone scaffold represents one of the main challenges in the total synthesis of caprazamycins and their analogues $[18,19,21,22]$. To the best of our knowledge, a simple thermally promoted nucleophilic attack of the linker unit to a $7^{\prime}$-carboxylic acid ester moiety has not been successfully explored for the diazepanone-forming step before. The good yields of 6 obtained from this reaction strongly suggest that it should be investigated for caprazamycin syntheses in a more systematic way in the future. Additionally, it has not escaped our notion that this transformation might even be considered to be "biomimetic" with respect to the proposed biosynthesis of caprazamycins [41,42]. However, it seems possible that a cyclization precursor decorated with more functional groups (i.e., an analogue of 4 closer resembling a non-simplified caprazamycin precursor) might undergo decomposition reactions at the elevated temperatures needed for diazepanone formation. Such hurdles might be overcome by the choice of more reactive (i.e., less bulky) ester units in the $7^{\prime}$-position, thus potentially allowing lower temperatures for the ring closure reaction after Fmoc deprotection.

The missing inhibitory potential of the deprotected uridine-derived diazepanone 7 towards MraY shows that a simplified 5'-defunctionalized ("5'-deoxy") version of the caprazamycin core structure ("caprazol") does not inhibit this bacterial target protein, at least not in the relevant concentration range. This supports the conclusion that at least some of the functionalized side chain structures found in caprazamycins (cf. Figure 1) are relevant for biological activity.

In summary, we report an interesting and unexpected formation of a caprazamycin-like seven-membered diazepanone ring in a supposedly facile ester cleavage en route to muraymycin analogues. It is particularly remarkable that this side product was obtained in yields much higher than those of the desired product. Additionally, the complete cleavage of the Fmoc group under the (supposedly slightly acidic) reaction conditions was surprising. The observed side reaction might pave the way for the development of more efficient strategies for diazepanone formation in the synthesis of caprazamycin analogues.

\section{Materials and Methods}

\subsection{Synthesis}

General methods: All chemicals were purchased from standard suppliers and used without further purification. Reactions involving oxygen and/or moisture sensitive reagents were carried out under an atmosphere of nitrogen using anhydrous solvents. Anhydrous solvents were obtained in the following manner: THF was dried with a solvent purification system (MBRAUN MB SPS 800, M. Braun, Garching, Germany). All other solvents were of technical quality and distilled prior to use, and deionized water was used throughout. Analytical TLC was performed on aluminum plates precoated with silica gel $60 \mathrm{~F}_{254}$ (VWR, Darmstadt, Germany). Visualization of the spots was carried out using UV light (254 nm) and/or staining under heating $\left(\mathrm{H}_{2} \mathrm{SO}_{4}\right.$ staining solution: $4 \mathrm{~g}$ vanillin, $25 \mathrm{~mL}$ conc. $\mathrm{H}_{2} \mathrm{SO}_{4}, 80 \mathrm{~mL} \mathrm{AcOH}$ and $680 \mathrm{~mL} \mathrm{MeOH}$; $\mathrm{KMnO}_{4}$ staining solution: $1 \mathrm{~g} \mathrm{KMnO}, 6$ g K $\mathrm{KMO}_{3}$ and $1.5 \mathrm{~mL} 1.25 \mathrm{~m} \mathrm{NaOH}$ solution, all dissolved in $100 \mathrm{~mL} \mathrm{H}_{2} \mathrm{O}$; ninhydrin staining solution: $0.3 \mathrm{~g}$ ninhydrin, $3 \mathrm{~mL}$ AcOH and $100 \mathrm{~mL}$ 1-butanol). Preparative TLC was carried out on a Chromatotron ${ }^{\mathrm{TM}}$ 7924T by T-Squared Technology (San Bruno/CA, USA), using glass plates coated with silica gel 60 $\mathrm{PF}_{254}$ containing a fluorescent indicator (VWR, Darmstadt, Germany; thickness depending on the amount of crude material to be separated, for 50-500 mg: $1 \mathrm{~mm}$ layer). Column chromatography was carried out on silica gel 60 (0.040-0.063 mm, 230-400 mesh ASTM, VWR, Darmstadt, Germany) under flash conditions. Semipreparative HPLC was performed on an Agilent Technologies 1200 Series system equipped with an MWD detector (254/280) (Agilent Trechnologies, Waldbronn, Germany) and a LiChroCart ${ }^{\mathrm{TM}}$ column $(10 \times 250 \mathrm{~mm})$ containing reversed phase silica gel Purospher ${ }^{\mathrm{TM}} \mathrm{RP} 18 \mathrm{e}$ ( $5 \mu \mathrm{m}, \mathrm{VWR}$, Darmstadt, Germany). Method: eluent A water, eluent B MeCN; 0-35 min gradient of B (10\%-100\%), 35-39 min 100\% B, 39-40 min gradient of B (100\%-10\%), 40-45 $\mathrm{min} 10 \%$ B; flow $3 \mathrm{~mL} / \mathrm{min}$. 
$500 \mathrm{MHz}^{-1} \mathrm{H}, 126 \mathrm{MHz}^{-13} \mathrm{C}$, and $376 \mathrm{MHz}^{-19} \mathrm{~F}$ NMR spectra were recorded on Bruker AVANCE-500 spectrometers (Bruker, Bremen, Germany). All ${ }^{13} \mathrm{C}$ and ${ }^{19} \mathrm{~F}$ NMR spectra were ${ }^{1} \mathrm{H}$-decoupled. All spectra were recorded at room temperature and were referenced internally to solvent reference frequencies wherever possible. Chemical shifts $(\delta)$ are given in ppm and coupling constants $(J)$ are reported in $\mathrm{Hz}$. Assignment of signals was carried out using ${ }^{1} \mathrm{H},{ }_{1}^{1} \mathrm{H}-\mathrm{COSY}, \mathrm{HSQC}$ and HMBC spectra. High-resolution ESI mass spectra were measured on a Dionex UltiMate 3000 HPLC system and on a Bruker time-of-flight (TOF) maXis (Bruker, Bremen, Germany). Infrared spectra (IR) were measured on a Bruker Vertex 70 spectrometer equipped with an integrated ATR unit (PlatinumATR ${ }^{\mathrm{TM}}$, Bruker, Bremen, Germany). Wavenumbers ( $\tilde{v})$ are quoted in $\mathrm{cm}^{-1}$. UV spectra were measured on an Agilent Cary 100 spectrophotometer (Agilent Trechnologies, Waldbronn, Germany). Wavelengths of maximum absorption $\left(\lambda_{\max }\right)$ are reported in $\mathrm{nm}$.

$N$-Fmoc-protected aminoalkylated uridinyl amino acid tert-butyl ester (4): Protected nucleosyl amino acid 2 [30,37,38] (98.0 mg, $0.167 \mathrm{mmol})$ was dissolved in THF (6 mL) over molecular sieves (4 $⿱$ A). $\mathrm{N}$-Fmoc-protected aldehyde 3 [36] (75.0 $\mathrm{mg}, 0.254 \mathrm{mmol})$ was added and the mixture was stirred at $\mathrm{rt}$ for $21 \mathrm{~h}$. Amberlyst ${ }^{\mathrm{TM}}(7.9 \mathrm{mg}, 37 \mu \mathrm{mol})$ and sodium triacetoxyborohydride $(75.7 \mathrm{mg}, 0.357 \mathrm{mmol})$ were added and the solution was stirred at $\mathrm{rt}$ for further $24 \mathrm{~h}$. The reaction mixture was then filtered, and the molecular sieves were washed with EtOAc. The combined filtrates were washed with saturated (sat.) $\mathrm{Na}_{2} \mathrm{CO}_{3}$ solution $(50 \mathrm{~mL})$ and the aqueous layer was extracted with EtOAc $(50 \mathrm{~mL})$. The organic layer was dried over $\mathrm{Na}_{2} \mathrm{SO}_{4}$ and the solvent was evaporated under reduced pressure. The resultant crude product was purified by column chromatography (100:0 $\rightarrow$ 99:1 $\left.\rightarrow 98: 2, \mathrm{CH}_{2} \mathrm{Cl}_{2}-\mathrm{MeOH}\right)$ to give 4 as a colorless foam $(102 \mathrm{mg}, 71 \%) .{ }^{1} \mathrm{H}$ NMR $\left(500 \mathrm{MHz}, \mathrm{CDCl}_{3}\right): \delta[\mathrm{ppm}]=0.07\left(\mathrm{~s}, 3 \mathrm{H}, \mathrm{SiCH}_{3}\right), 0.07(\mathrm{~s}, 3 \mathrm{H}$, $\left.\mathrm{SiCH}_{3}\right), 0.07\left(\mathrm{~s}, 3 \mathrm{H}, \mathrm{SiCH}_{3}\right), 0.09\left(\mathrm{~s}, 3 \mathrm{H}, \mathrm{SiCH}_{3}\right), 0.88\left(\mathrm{~s}, 9 \mathrm{H}, \mathrm{SiC}\left(\mathrm{CH}_{3}\right)_{3}\right), 0.90\left(\mathrm{~s}, 9 \mathrm{H}, \mathrm{SiC}\left(\mathrm{CH}_{3}\right)_{3}\right), 1.47(\mathrm{~s}$, $\left.9 \mathrm{H}, \mathrm{OC}\left(\mathrm{CH}_{3}\right)_{3}\right), 1.65-1.71\left(\mathrm{~m}, 2 \mathrm{H}, 2^{\prime \prime}-\mathrm{H}\right), 1.83-1.89\left(\mathrm{~m}, 1 \mathrm{H}, 5^{\prime}-\mathrm{H}_{\mathrm{a}}\right), 1.98-2.02\left(\mathrm{~m}, 1 \mathrm{H}, 5^{\prime}-\mathrm{H}_{\mathrm{b}}\right), 2.54-2.59$ $\left(\mathrm{m}, 1 \mathrm{H}, 1^{\prime \prime}-\mathrm{H}_{\mathrm{a}}\right), 2.70-2.75\left(\mathrm{~m}, 1 \mathrm{H}, 1^{\prime \prime}-\mathrm{H}_{\mathrm{b}}\right), 3.24-3.35\left(\mathrm{~m}, 3 \mathrm{H}, 3^{\prime \prime}-\mathrm{H}, 6^{\prime}-\mathrm{H}\right), 3.66-3.68\left(\mathrm{~m}, 1 \mathrm{H}, 3^{\prime}-\mathrm{H}\right)$, 4.10-4.14 (m, 1H, 4'-H), 4.20-4.25 (m, 2H, 2'-H, Fmoc-9-H), 4.33-4.42 (m, 2H, Fmoc- $\left.\mathrm{CH}_{2}\right), 5.41-5.44$ $\left(\mathrm{m}, 1 \mathrm{H}, 3^{\prime \prime}-\mathrm{NH}\right), 5.59\left(\mathrm{~s}, 1 \mathrm{H}, 1^{\prime}-\mathrm{H}\right), 5.71(\mathrm{~d}, J=8.2 \mathrm{~Hz}, 1 \mathrm{H}, 5-\mathrm{H}), 7.29(\mathrm{t}, J=7.4 \mathrm{~Hz}, 2 \mathrm{H}$, Fmoc-3-H, Fmoc-6-H), 7.34 (d, $J=8.2 \mathrm{~Hz}, 1 \mathrm{H}, 6-\mathrm{H}), 7.38(\mathrm{t}, J=7.4 \mathrm{~Hz}, 2 \mathrm{H}$, Fmoc-2-H, Fmoc-7-H), 7.59 (d, $J=$ $7.4 \mathrm{~Hz}, 2 \mathrm{H}$, Fmoc-4-H, Fmoc-5-H), 7.75 (d, $J=7.4$ Hz, 2H, Fmoc-1-H, Fmoc-8-H). ${ }^{13} \mathrm{C}$ NMR $(126 \mathrm{MHz}$, $\left.\mathrm{CDCl}_{3}\right): \delta[\mathrm{ppm}]=-4.74\left(\mathrm{SiCH}_{3}\right),-4.67\left(\mathrm{SiCH}_{3}\right),-4.44\left(\mathrm{SiCH}_{3}\right),-4.02\left(\mathrm{SiCH}_{3}\right), 18.08\left(\mathrm{SiC}\left(\mathrm{CH}_{3}\right)_{3}\right), 18.18$ $\left(\mathrm{SiC}\left(\mathrm{CH}_{3}\right)_{3}\right), 25.88\left(\mathrm{SiC}\left(\underline{\mathrm{CH}}_{3}\right)_{3}\right), 25.95\left(\mathrm{SiC}\left(\underline{\mathrm{CH}}_{3}\right)_{3}\right), 28.21\left(\mathrm{OC}\left(\underline{\mathrm{CH}}_{3}\right)_{3}\right), 29.90\left(\mathrm{C}-2^{\prime \prime}\right), 37.36\left(\mathrm{C}-5^{\prime}\right), 39.30$ $\left(\mathrm{C}-3^{\prime \prime}\right), 45.67$ (C-1"), 47.38 (Fmoc-C-9), 60.03 (C-6'), $66.72\left(\right.$ Fmoc-CH $\left._{2}\right), 74.87\left(\mathrm{C}-2^{\prime}\right), 75.39\left(\mathrm{C}-3^{\prime}\right), 81.08$ $\left(\mathrm{C}-4^{\prime}\right), 81.93\left(\mathrm{OC}\left(\mathrm{CH}_{3}\right)_{3}\right), 92.41\left(\mathrm{C}-1^{\prime}\right), 102.32(\mathrm{C}-5), 120.07$ (Fmoc-C-1, Fmoc-C-8), 125.21 (Fmoc-C-4, Fmoc-C-5), 127.11 (Fmoc-C-3, Fmoc-C-6), 127.75 (Fmoc-C-2, Fmoc-C-7), 140.53 (C-6), 141.40 (Fmoc-C-1a, Fmoc-C-8a), 144.12 (Fmoc-C-4a, Fmoc-C-5a), 150.07 (C-2), 156.61 (urea-C=O), 163.22 (C-4), 173.96 (C-7'). HRMS (ESI): calcd. for $\mathrm{C}_{45} \mathrm{H}_{69} \mathrm{~N}_{4} \mathrm{O}_{9} \mathrm{Si}_{2}: 865.4598[\mathrm{M}+\mathrm{H}]^{+}$, found 865.4608. IR (ATR): $\tilde{v}=2929,2856$, $1687,1450,1251,1151,836,776,739$. UV $\left(\mathrm{CHCl}_{3}\right): \lambda_{\max }=266,301$. optical rotation: $\alpha_{\mathrm{D}}^{20}=+90.0(\mathrm{c}=1.0$, $\left.\mathrm{CHCl}_{3}\right)$. TLC: $R_{\mathrm{f}}=0.20$ (19:1, $\left.\mathrm{CH}_{2} \mathrm{Cl}_{2}-\mathrm{MeOH}\right)$.

$\mathrm{N}$-Fmoc-protected aminoalkylated uridinyl amino acid (5): $\mathrm{N}$-Fmoc-protected aminoalkylated uridinyl amino acid tert-butyl ester $4(54.4 \mathrm{mg}, 62.9 \mu \mathrm{mol})$ was dissolved in toluene $(10 \mathrm{~mL})$. Silica (409 mg) was added, the reaction mixture was heated to $80^{\circ} \mathrm{C}$ and stirred at this temperature for 1 day. Then, the mixture was allowed to cool to rt and stirred at $\mathrm{rt}$ for further 2 days. The mixture was filtered, the silica was washed with a mixture of $\mathrm{CH}_{2} \mathrm{Cl}_{2}$ and $\mathrm{MeOH}(1: 1)$, and the solvent of the combined filtrates was evaporated under reduced pressure. The resultant crude product was purified by preparative TLC (chromatotron, 9:1 $\rightarrow 4: 1, \mathrm{CH}_{2} \mathrm{Cl}_{2}-\mathrm{MeOH}$ ) to give 5 as a yellowish solid (24.6 $\mathrm{mg}$, $48 \%) .{ }^{1} \mathrm{H}$ NMR $\left(500 \mathrm{MHz}, \mathrm{CDCl}_{3}\right): \delta[\mathrm{ppm}]=-0.13\left(\mathrm{~s}, 3 \mathrm{H}, \mathrm{SiCH}_{3}\right),-0.01\left(\mathrm{~s}, 3 \mathrm{H}, \mathrm{SiCH}_{3}\right), 0.07(\mathrm{~s}, 6 \mathrm{H}$, $\left.\mathrm{SiCH}_{3}\right), 0.81\left(\mathrm{~s}, 9 \mathrm{H}, \mathrm{SiC}\left(\mathrm{CH}_{3}\right)_{3}\right), 0.89\left(\mathrm{~s}, 9 \mathrm{H}, \mathrm{SiC}\left(\mathrm{CH}_{3}\right)_{3}\right), 1.78-1.94\left(\mathrm{~m}, 2 \mathrm{H}, 2^{\prime \prime}-\mathrm{H}\right), 2.03-2.33(\mathrm{~m}, 2 \mathrm{H}$, $\left.5^{\prime}-\mathrm{H}\right), 3.02-4.53\left(\mathrm{~m}, 11 \mathrm{H}, 1^{\prime \prime}-\mathrm{H}, 3^{\prime \prime}-\mathrm{H}, 6^{\prime}-\mathrm{H}, 2^{\prime}-\mathrm{H}, 3^{\prime}-\mathrm{H}, 4^{\prime}-\mathrm{H}\right.$, Fmoc-9-H, Fmoc-CH $\left.\mathrm{CH}_{2}\right), 5.02-5.19(\mathrm{~m}, 2 \mathrm{H}$, $\left.1^{\prime}-\mathrm{H}, 3^{\prime \prime}-\mathrm{NH}\right), 5.55-5.71(\mathrm{~m}, 1 \mathrm{H}, 5-\mathrm{H}), 7.26-7.29$ (m, 2H, Fmoc-3-H, Fmoc-6-H), 7.33-7.37 (m, 3H, 6-H, Fmoc-2-H, Fmoc-7-H), 7.51-7.62 (m, 2H, Fmoc-4-H, Fmoc-5-H), 7.72 (d, $J=7.7$ Hz, 2H, Fmoc-1-H, 
Fmoc-8-H). MS (ESI): $m / z=809.51[\mathrm{M}+\mathrm{H}]^{+}$. HRMS (ESI): calcd. for $\mathrm{C}_{41} \mathrm{H}_{61} \mathrm{~N}_{4} \mathrm{O}_{9} \mathrm{Si}_{2}: 809.3972[\mathrm{M}+$ $\mathrm{H}]^{+}$, found 809.3949. TLC: $R_{\mathrm{f}}=0.18\left(9: 1, \mathrm{CH}_{2} \mathrm{Cl}_{2}-\mathrm{MeOH}\right)$.

Protected uridine-derived diazepanone (6): $\mathrm{N}$-Fmoc-protected aminoalkylated uridinyl amino acid tert-butyl ester $4(63.1 \mathrm{mg}, 49.8 \mu \mathrm{mol})$ was dissolved in toluene $(8 \mathrm{~mL})$. Silica $(208 \mathrm{mg})$ was added and the reaction mixture was stirred under reflux for 1.5 days. Then, the mixture was allowed to cool to $\mathrm{rt}$ and the solvent was evaporated under reduced pressure. The resultant crude product was purified by column chromatography ( $95: 5 \rightarrow$ 9:1 $\rightarrow 4: 1, \mathrm{CH}_{2} \mathrm{Cl}_{2}-\mathrm{MeOH}$ ) to give 6 as a colorless oil (19.3 mg, $68 \%) .{ }^{1} \mathrm{H}$ NMR $\left(500 \mathrm{MHz}, \mathrm{CD}_{3} \mathrm{OD}\right): \delta[\mathrm{ppm}]=0.04\left(\mathrm{~s}, 3 \mathrm{H}, \mathrm{SiCH}_{3}\right), 0.09\left(\mathrm{~s}, 3 \mathrm{H}, \mathrm{SiCH}_{3}\right), 0.13(\mathrm{~s}, 3 \mathrm{H}$, $\left.\mathrm{SiCH}_{3}\right), 0.16\left(\mathrm{~s}, 3 \mathrm{H}, \mathrm{SiCH}_{3}\right), 0.89\left(\mathrm{~s}, 9 \mathrm{H}, \mathrm{SiC}\left(\mathrm{CH}_{3}\right)_{3}\right), 0.94\left(\mathrm{~s}, 9 \mathrm{H}, \mathrm{SiC}\left(\mathrm{CH}_{3}\right)_{3}\right), 1.57-1.66\left(\mathrm{~m}, 1 \mathrm{H}, 2^{\prime \prime}-\mathrm{H}_{\mathrm{a}}\right)$, 1.71-1.77 (m, 2H, 2"' $\left.-\mathrm{H}_{\mathrm{b}}, 5^{\prime}-\mathrm{H}_{\mathrm{a}}\right), 2.32-2.37\left(\mathrm{~m}, 1 \mathrm{H}, 5^{\prime}-\mathrm{H}_{\mathrm{b}}\right), 2.90-2.95\left(\mathrm{~m}, 1 \mathrm{H}, 1^{\prime \prime}-\mathrm{H}_{\mathrm{a}}\right), 3.23-3.27(\mathrm{~m}, 2 \mathrm{H}$, $\left.1^{\prime \prime}-\mathrm{H}_{\mathrm{b}}, 3^{\prime \prime}-\mathrm{H}_{\mathrm{a}}\right), 3.35-3.42\left(\mathrm{~m}, 1 \mathrm{H}, 3^{\prime \prime}-\mathrm{H}_{\mathrm{b}}\right), 3.55\left(\mathrm{dd}, J=8.2,5.3 \mathrm{~Hz}, 1 \mathrm{H}, 6^{\prime}-\mathrm{H}\right), 3.99(\mathrm{dd}, J=4.4,3.3 \mathrm{~Hz}, 1 \mathrm{H}$, $\left.3^{\prime}-\mathrm{H}\right), 4.13\left(\mathrm{ddd}, J=10.6,3.3,3.3 \mathrm{~Hz}, 1 \mathrm{H}, 4^{\prime}-\mathrm{H}\right), 4.40\left(\mathrm{dd}, J=5.9,4.4 \mathrm{~Hz}, 1 \mathrm{H}, 2^{\prime}-\mathrm{H}\right), 5.77(\mathrm{~d}, J=8.1 \mathrm{~Hz}, 1 \mathrm{H}$, $5-\mathrm{H}), 5.84\left(\mathrm{~d}, J=5.9 \mathrm{~Hz}, 1 \mathrm{H}, 1^{\prime}-\mathrm{H}\right), 7.67(\mathrm{~d}, J=8.1 \mathrm{~Hz}, 1 \mathrm{H}, 6-\mathrm{H}) .{ }^{13} \mathrm{C}$ NMR $\left(126 \mathrm{MHz}, \mathrm{CD}_{3} \mathrm{OD}\right): \delta[\mathrm{ppm}]$ $=-4.64\left(\mathrm{SiCH}_{3}\right),-4.38\left(\mathrm{SiCH}_{3}\right),-4.35\left(\mathrm{SiCH}_{3}\right),-4.17\left(\mathrm{SiCH}_{3}\right), 18.87\left(\mathrm{SiC}\left(\mathrm{CH}_{3}\right)_{3}\right), 18.97\left(\mathrm{SiC}\left(\mathrm{CH}_{3}\right)_{3}\right)$, $26.34\left(\mathrm{SiC}\left(\mathrm{CH}_{3}\right)_{3}\right), 26.42\left(\mathrm{SiC}\left(\mathrm{CH}_{3}\right)_{3}\right), 31.43\left(\mathrm{C}-2^{\prime \prime}\right), 36.99\left(\mathrm{C}-5^{\prime}\right), 41.99\left(\mathrm{C}-3^{\prime \prime}\right), 51.58\left(\mathrm{C}-1^{\prime \prime}\right), 58.68\left(\mathrm{C}-6^{\prime}\right)$, 75.35 (C-2'), 77.09 (C-3'), 84.67 (C-4'), 91.31 (C-1'), 103.23 (C-5), 143.12 (C-6), 152.28 (C-2), 165.97 (C-4), 178.69 (C-7'). MS (ESI): $m / z=569.33$ [M + H] ${ }^{+}$. HRMS (ESI): calcd. for $\mathrm{C}_{26} \mathrm{H}_{49} \mathrm{~N}_{4} \mathrm{O}_{6} \mathrm{Si}_{2}: 569.3185$ [M + $\mathrm{H}]^{+}$, found 569.3177. IR (ATR): $\tilde{v}=2920,2851,1738,1457,1374,1229,1070,797 . \mathrm{UV}\left(\mathrm{CHCl}_{3}\right): \lambda_{\max }=$ 224. TLC: $R_{\mathrm{f}}=0.24\left(9: 1, \mathrm{CH}_{2} \mathrm{Cl}_{2}-\mathrm{MeOH}\right)$.

Uridine-derived diazepanone (7): Protected uridine-derived diazepanone 6 (6.1 mg, $10.7 \mu \mathrm{mol})$ was dissolved in TFA ( $80 \%$ in water, $3 \mathrm{~mL}$ ). The reaction mixture was stirred at $\mathrm{rt}$ for $24 \mathrm{~h}$ and the solvent was evaporated under reduced pressure. The resultant crude product was purified by semipreparative HPLC to give 7 (TFA salt) as a colorless solid ( $2.0 \mathrm{mg}$ containing $~ 30 \%$ of an unknown uracil-derived impurity; 100\% yield: $4.9 \mathrm{mg}) .{ }^{1} \mathrm{H}$ NMR $\left(500 \mathrm{MHz}, \mathrm{D}_{2} \mathrm{O}\right): \delta[\mathrm{ppm}]=1.77-1.85\left(\mathrm{~m}, 1 \mathrm{H}, 2^{\prime \prime}-\mathrm{H}_{\mathrm{a}}\right), 1.94-2.05$ $\left(\mathrm{m}, 2 \mathrm{H}, 5^{\prime}-\mathrm{H}_{\mathrm{a}}, 2^{\prime \prime}-\mathrm{H}_{\mathrm{b}}\right), 2.50-2.55\left(\mathrm{~m}, 1 \mathrm{H}, 5^{\prime}-\mathrm{H}_{\mathrm{b}}\right), 3.22-3.27\left(\mathrm{~m}, 1 \mathrm{H}, 3^{\prime \prime}-\mathrm{H}_{\mathrm{a}}\right), 3.35-3.37\left(\mathrm{~m}, 1 \mathrm{H}, 1^{\prime \prime}-\mathrm{H}_{\mathrm{a}}\right)$, 3.47-3.52 (m, 2H, 1"'- $\left.\mathrm{H}_{\mathrm{b}}, 3^{\prime \prime}-\mathrm{H}_{\mathrm{b}}\right), 4.07-4.11\left(\mathrm{~m}, 2 \mathrm{H}, 3^{\prime}-\mathrm{H}, 4^{\prime}-\mathrm{H}\right), 4.14-4.17\left(\mathrm{~m}, 1 \mathrm{H}, 6^{\prime}-\mathrm{H}\right), 4.43(\mathrm{dd}, J=$ $\left.5.0,3.9 \mathrm{~Hz}, 1 \mathrm{H}, 2^{\prime}-\mathrm{H}\right), 5.71\left(\mathrm{~d}, J=3.9 \mathrm{~Hz}, 1 \mathrm{H}, 1^{\prime}-\mathrm{H}\right), 5.76(\mathrm{~d}, J=7.7 \mathrm{~Hz}, 1 \mathrm{H}$, unknown, probably $5-\mathrm{H})$, $5.86(\mathrm{~d}, J=8.1 \mathrm{~Hz}, 1 \mathrm{H}, 5-\mathrm{H}), 7.50(\mathrm{~d}, J=7.6 \mathrm{~Hz}, 1 \mathrm{H}$, unknown, probably $6-\mathrm{H}), 7.63(\mathrm{~d}, J=8.1 \mathrm{~Hz}, 1 \mathrm{H}$, 6-H). ${ }^{13} \mathrm{C}$ NMR (126 MHz, $\left.\mathrm{D}_{2} \mathrm{O}\right): \delta$ [ppm] = $26.70\left(\mathrm{C}-2^{\prime \prime}\right), 32.73\left(\mathrm{C}-5^{\prime}\right), 39.77\left(\mathrm{C}-3^{\prime \prime}\right), 48.83\left(\mathrm{C}-1^{\prime \prime}\right), 56.78$ (C-6'), $72.66\left(\mathrm{C}-2^{\prime}\right), 73.15\left(\mathrm{C}-3^{\prime}\right), 80.67\left(\mathrm{C}-4^{\prime}\right), 91.97\left(\mathrm{C}-1^{\prime}\right), 101.10$ (unknown, probably C-5), 102.34 (C-5), 142.95 (C-6), 143.47 (unknown, probably C-6), 151.52 (C-2), 166.31 (C-4), 173.19 (C-7'). ${ }^{19}$ F NMR (376 $\mathrm{MHz}, \mathrm{D}_{2} \mathrm{O}$ ): -75.69 (TFA-CF ${ }_{3}$ ). MS (ESI): $m / z=341.11[\mathrm{M}+\mathrm{H}]^{+}$. HRMS (ESI): calcd. for $\mathrm{C}_{14} \mathrm{H}_{21} \mathrm{~N}_{4} \mathrm{O}_{6}$ : 341.1456 $[\mathrm{M}+\mathrm{H}]^{+}$, found 341.1448. UV $\left(\mathrm{H}_{2} \mathrm{O}\right): \lambda_{\max }=202$, 260. HPLC: $t_{\mathrm{R}}=8.4 \mathrm{~min}$.

\subsection{Overexpression of MraY from S. aureus}

The overexpression of MraY was performed as described before $[32,33,40]$.

\subsection{Fluorescence-Based MraY Assay}

The MraY assay was performed as described before [32,33,40]. Measured data are shown in the Supplementary Materials, Figure S1.

Supplementary Materials: The following are available online, data from the MraY assays, copies of NMR and IR spectra.

Author Contributions: Conceptualization, C.D.; formal analysis, K.L., S.K. and C.D.; funding acquisition, C.D.; investigation, K.L., S.K.; project administration, C.D.; supervision, C.D.; writing-original draft preparation, K.L.; writing-review and editing, K.L., S.K. and C.D. All authors have read and agreed to the published version of the manuscript.

Funding: This research was funded by the Deutsche Forschungsgemeinschaft (DFG), grant DU 1095/5-1. The APC was funded by Saarland University.

Acknowledgments: We thank Jannine Ludwig (Saarland University) for technical assistance.

Conflicts of Interest: The authors declare no conflict of interest. 


\section{References}

1. Taubes, G. The bacteria fight back. Science 2008, 321, 356-361. [CrossRef] [PubMed]

2. Cooper, M.A.; Shlaes, D. Fix the antibiotics pipeline. Nature 2011, 472, 32. [CrossRef] [PubMed]

3. Von Nussbaum, F.; Brands, M.; Hinzen, B.; Weigand, S.; Häbich, D. Antibacterial Natural Products in Medicinal Chemistry - Exodus or Revival? Angew. Chem. Int. Ed. 2006, 45, 5072-5129. [CrossRef]

4. Walsh, C. Where will new antibiotics come from? Nat. Rev. Microbiol. 2003, 1, 65-70. [CrossRef] [PubMed]

5. Winn, M.; Goss, R.J.M.; Kimura, K.; Bugg, T.D.H. Antimicrobial nucleoside antibiotics targeting cell wall assembly: Recent advances in structure-function studies and nucleoside biosynthesis. Nat. Prod. Rep. 2010, 27, 279-304. [CrossRef]

6. Wiegmann, D.; Koppermann, S.; Wirth, M.; Niro, G.; Leyerer, K.; Ducho, C. Muraymycin nucleoside-peptide antibiotics: Uridine-derived natural products as lead structures for the development of novel antibacterial agents. Beilstein J. Org. Chem. 2016, 12, 769-795. [CrossRef]

7. Ichikawa, S.; Yamaguchi, M.; Matsuda, A. Antibacterial Nucleoside Natural Products Inhibiting Phospho-MurNAc-Pentapeptide Translocase; Chemistry and Structure-activity Relationship. Curr. Med. Chem. 2015, 22, 3951-3979. [CrossRef]

8. Struve, W.G.; Neuhaus, F.C. Evidence for an Initial Acceptor of UDP-NAc-Muramyl-Pentapeptide in the Synthesis of Bacterial Mucopeptide. Biochem. Biophys. Res. Commun. 1965, 18, 6-12. [CrossRef]

9. Anderson, J.S.; Matsuhashi, M.; Haskin, M.A.; Strominger, J.L. Lipid-Phosphoacetylmuramyl-pentapeptide and Lipid-Phosphodisaccharide-pentapeptide: Presumed Membrane Transport Intermediates in Cell Wall Synthesis. Proc. Natl. Acad. Sci. USA 1965, 53, 881-889. [CrossRef]

10. Heydanek, M.G., Jr.; Struve, W.G.; Neuhaus, F.C. Initial state in peptidoglycan synthesis. III. Kinetics and uncoupling of phospho- $N$-acetylmuramyl-pentapeptide translocase. Biochemistry 1969, 8, 1214-1221. [CrossRef]

11. Ikeda, M.; Wachi, M.; Jung, H.K.; Ishino, F.; Matsuhashi, M. The Escherichia coli mraY gene encoding UDP-N-acetylmuramoyl-pentapeptide: Undecaprenyl-phosphate phospho- $N$-acetylmuramoyl-pentapeptide transferase. J. Bacteriol. 1991, 173, 1021-1026. [CrossRef] [PubMed]

12. Boyle, D.S.; Donachie, W.D. mraY is an essential gene for cell growth in Escherichia coli. J. Bacteriol. 1998, 180, 6429-6432. [CrossRef] [PubMed]

13. Bouhss, A.; Mengin-Lecreulx, D.; Le Beller, D.; Van Heijenoort, J. Topological analysis of the MraY protein catalysing the first membrane step of peptidoglycan synthesis. Mol. Microbiol. 1999, 34, 576-585. [CrossRef] [PubMed]

14. McDonald, L.A.; Barbieri, L.R.; Carter, G.T.; Lenoy, E.; Lotvin, J.; Petersen, P.J.; Siegel, M.M.; Singh, G.; Williamson, R.T. Structures of the Muraymycins, Novel Peptidoglycan Biosynthesis Inhibitors. J. Am. Chem. Soc. 2002, 124, 10260-10261. [CrossRef] [PubMed]

15. Cui, Z.; Wang, X.; Koppermann, S.; Thorson, J.S.; Ducho, C.; Van Lanen, S.G. Antibacterial Muraymycins from Mutant Strains of Streptomyces sp. NRRL 30471. J. Nat. Prod. 2018, 81, 942-948. [CrossRef] [PubMed]

16. Igarashi, M.; Nakagawa, N.; Doi, N.; Hattori, S.; Naganawa, H.; Hamada, M. Caprazamycin B, a Novel Anti-tuberculosis Antibiotic, from Streptomyces sp. J. Antibiot. 2003, 56, 580-583. [CrossRef] [PubMed]

17. Igarashi, M.; Takahashi, Y.; Shitara, T.; Nakamura, H.; Naganawa, H.; Miyake, T.; Akamatsu, Y. Caprazamycins, Novel Lipo-nucleoside Antibiotics, from Streptomyces sp. J. Antibiot. 2005, 58, 327-337. [CrossRef]

18. Nakamura, H.; Tsukano, C.; Yasui, M.; Yokouchi, S.; Igarashi, M.; Takemoto, Y. Total Synthesis of (-)-Caprazamycin A. Angew. Chem. Int. Ed. 2015, 54, 3136-3139. [CrossRef]

19. Abe, H.; Gopinath, P.; Ravi, G.; Wang, L.; Watanabe, T.; Shibasaki, M. Synthesis of caprazamycin B. Tetrahedron Lett. 2015, 56, 3782-3785. [CrossRef]

20. Hirano, S.; Ichikawa, S.; Matsuda, A. Synthesis of Caprazamycin Analogues and Their Structure-Activity Relationship for Antibacterial Activity. J. Org. Chem. 2008, 73, 569-577. [CrossRef]

21. Linder, R.; Ducho, C. Unified Synthesis of Densely Functionalized Amino Acid Building Blocks for the Preparation of Caprazamycin Nucleoside Antibiotics. Eur. J. Org. Chem. 2019, 2019, 1523-1534. [CrossRef]

22. Sarabia, F.; Vivar-García, C.; García-Ruiz, C.; Martín-Ortiz, L.; Romero-Carrasco, A. Exploring the Chemistry of Epoxy Amides for the Synthesis of the 2"'-epi-Diazepanone Core of Liposidomycins and Caprazamycins. J. Org. Chem. 2012, 77, 1328-1339. [CrossRef] [PubMed] 
23. Chung, B.C.; Zhao, J.; Gillespie, R.A.; Kwon, D.-Y.; Guan, Z.; Hong, J.; Zhou, P.; Lee, S.-Y. Crystal Structure of MraY, an Essential Membrane Enzyme for Bacterial Cell Wall Synthesis. Science 2013, 341, 1012-1016. [CrossRef] [PubMed]

24. Chung, B.C.; Mashalidis, E.H.; Tanino, T.; Kim, M.; Matsuda, A.; Hong, J.; Ichikawa, S.; Lee, S.-Y. Structural insights into inhibition of lipid I production in bacterial cell wall synthesis. Nature 2016, 533, 557-560. [CrossRef]

25. Koppermann, S.; Ducho, C. Natural Products at Work: Structural Insights into Inhibition of the Bacterial Membrane Protein MraY. Angew. Chem. Int. Ed. 2016, 55, 11722-11724. [CrossRef]

26. Yamashita, A.; Norton, E.; Petersen, P.J.; Rasmussen, B.A.; Singh, G.; Yang, Y.; Mansour, T.S.; Ho, D.M. Muraymycins, novel peptidoglycan biosynthesis inhibitors: Synthesis and SAR of their analogues. Bioorg. Med. Chem. Lett. 2003, 13, 3345-3350. [CrossRef]

27. Tanino, T.; Ichikawa, S.; Al-Dabbagh, B.; Bouhss, A.; Oyama, H.; Matsuda, A. Synthesis and Biological Evaluation of Muraymycin Analogues Active against Anti-Drug-Resistant Bacteria. ACS Med. Chem. Lett. 2010, 1, 258-262. [CrossRef] [PubMed]

28. Tanino, T.; Al-Dabbagh, B.; Mengin-Lecreulx, D.; Bouhss, A.; Oyama, H.; Ichikawa, S.; Matsuda, A. Mechanistic Analysis of Muraymycin Analogues: A Guide to the Design of MraY Inhibitors. J. Med. Chem. 2011, 54, 8421-8439. [CrossRef]

29. Takeoka, Y.; Tanino, T.; Sekiguchi, M.; Yonezawa, S.; Sakagami, M.; Takahashi, F.; Togame, H.; Tanaka, Y.; Takemoto, H.; Ichikawa, S.; et al. Expansion of Antibacterial Spectrum of Muraymycins toward Pseudomonas aeruginosa. ACS Med. Chem. Lett. 2014, 5, 556-560. [CrossRef]

30. Spork, A.P.; Büschleb, M.; Ries, O.; Wiegmann, D.; Boettcher, S.; Mihalyi, A.; Bugg, T.D.; Ducho, C. Lead Structures for New Antibacterials: Stereocontrolled Synthesis of a Bioactive Muraymycin Analogue. Chem.Eur. J. 2014, 20, 15292-15297. [CrossRef]

31. Mitachi, K.; Aleiwi, B.A.; Schneider, C.M.; Siricilla, S.; Kurosu, M. Stereocontrolled Total Synthesis of Muraymycin D1 Having a Dual Mode of Action against Mycobacterium tuberculosis. J. Am. Chem. Soc. 2016, 138, 12975-12980. [CrossRef] [PubMed]

32. Koppermann, S.; Cui, Z.; Fischer, P.D.; Wang, X.; Ludwig, J.; Thorson, J.S.; Van Lanen, S.G.; Ducho, C. Insights into the Target Interaction of Naturally Occurring Muraymycin Nucleoside Antibiotics. ChemMedChem 2018, 13, 779-784. [CrossRef] [PubMed]

33. Spork, A.P.; Koppermann, S.; Schier (née Wohnig), S.; Linder, R.; Ducho, C. Analogues of Muraymycin Nucleoside Antibiotics with Epimeric Uridine-Derived Core Structures. Molecules 2018, 23, 2868. [CrossRef] [PubMed]

34. Wiegmann, D.; Koppermann, S.; Ducho, C. Aminoribosylated Analogues of Muraymycin Nucleoside Antibiotics. Molecules 2018, 23, 3085. [CrossRef] [PubMed]

35. Heib, A.; Niro, G.; Weck, S.C.; Koppermann, S.; Ducho, C. Muraymycin Nucleoside Antibiotics: Structureactivity Relationship for Variations in the Nucleoside Unit. Molecules 2020, 25, 22. [CrossRef]

36. Leyerer, K.; Koppermann, S.; Ducho, C. Solid Phase-Supported Synthesis of Muraymycin Analogues. Eur. J. Org. Chem. 2019, 45, 7420-7431. [CrossRef]

37. Spork, A.P.; Ducho, C. Novel 5'-deoxy nucleosyl amino acid scaffolds for the synthesis of muraymycin analogues. Org. Biomol. Chem. 2010, 8, 2323-2326. [CrossRef]

38. Spork, A.P.; Wiegmann, D.; Granitzka, M.; Stalke, D.; Ducho, C. Stereoselective Synthesis of Uridine-Derived Nucleosyl Amino Acids. J. Org. Chem. 2011, 76, 10083-10098. [CrossRef]

39. Schmidtgall, B.; Höbartner, C.; Ducho, C. NAA-modified DNA oligonucleotides with zwitterionic backbones: Stereoselective synthesis of A-T phosphoramidite building blocks. Beilstein J. Org. Chem. 2015, 11, 50-60. [CrossRef]

40. Wohnig, S.; Spork, A.P.; Koppermann, S.; Mieskes, G.; Gisch, N.; Jahn, R.; Ducho, C. Total Synthesis of Dansylated Park's Nucleotide for High-Throughput MraY Assays. Chem. Eur. J. 2016, 22, 17813-17819. [CrossRef]

41. Kaysser, L.; Lutsch, L.; Siebenberg, S.; Wemakor, E.; Kammerer, B.; Gust, B. Identification and Manipulation of the Caprazamycin Gene Cluster Lead to New Simplified Liponucleoside Antibiotics and Give Insights into the Biosynthetic Pathway. J. Biol. Chem. 2009, 284, 14987-14996. [CrossRef] [PubMed]

42. Wiker, F.; Hauck, N.; Grond, S.; Gust, B. Caprazamycins: Biosynthesis and structure activity relationship studies. Int. J. Med. Microbiol. 2019, 309, 319-324. [CrossRef] [PubMed]

(C) 2020 by the authors. Licensee MDPI, Basel, Switzerland. This article is an open access article distributed under the terms and conditions of the Creative Commons Attribution (CC BY) license (http://creativecommons.org/licenses/by/4.0/). 


\title{
Communication \\ Formation of an Isomeric Mixture of Dienynes Instead of a Diallene
}

\author{
Susanne M. Petrova and Leiv K. Sydnes * \\ Department of Chemistry, University of Bergen, Allégt. 41, 5007 Bergen, Norway; susannapetrova@gmail.com \\ * Correspondence: leiv.sydnes@uib.no; Tel.: +47-55-583-450
}

Received: 17 April 2020; Accepted: 7 May 2020; Published: 11 May 2020

\begin{abstract}
Attempts to convert 1,1,2,2,7,7,8,8-octaethoxyocta-3,5-diyne to a symmetric allene by reduction with lithium aluminum hydride failed. Instead reduction accompanied by isomerization occurred and afforded 1,1,2,7,8,8-hexaethoxyocta-2,6-dien-4-yne as a mixture of three isomers in 63\% total isolated yield.
\end{abstract}

Keywords: conjugated diyne; LAH reduction; diacetal; pent-1,2,3,4-tetraene intermediate

\section{Introduction}

Since the synthesis of 3,3,4,4-tetraethoxybutyne (TEB) was reported some 15 years ago [1-3], many of its chemical properties have been uncovered and used to prepare a range of chemical compounds with rich structural diversity [4-15]. Among the most densely functionalized molecules made is 1,1,2,2,7,7,8,8-octaethoxyocta-3,5-diyne (1), which has one ketal moiety in propargylic position to each of the triple bonds [16]. The compound therefore belongs to a group of compounds that can undergo $\mathrm{S}_{\mathrm{N}} 2^{\prime}$ reactions by nucleophilic attack of the triple bond, which is accompanied by $\mathrm{C}-\mathrm{C}$ bond migration that leads to the release of a leaving group from the propargylic carbon and formation of an allene moiety. The most common leaving groups are alkanoates [17-19], bromide [20,21], and chloride [22,23], but examples involving alkoxides have also been published [24-27]. As for the nucleophiles, both carbanions and hydride have been applied [17-27].

On this basis, we envisaged that 1 might be used as a substrate to make a functionalized diallene by two $\mathrm{S}_{\mathrm{N}} 2^{\prime}$ reactions, one at each of the propargylic moieties, using hydride as a nucleophile (Scheme 1). Lithium aluminum hydride (LAH) was deemed to be a suitable reagent [23] but, as reported here, when the reaction was performed, the expected product was not obtained; instead, an isomeric mixture of 1,1,2,7,8,8-hexaethoxyocta-2,6-dien-4-yne (2) was the only product formed.

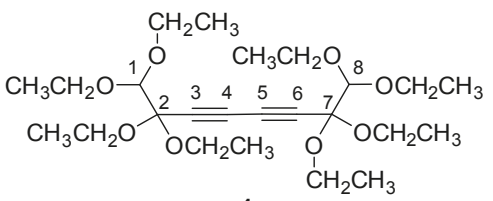

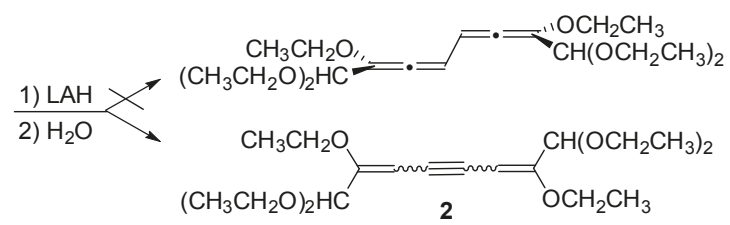

Scheme 1. Expected and obtained products from lithium aluminum hydride (LAH) reduction of $\mathbf{1}$.

\section{Results and Discussion}

The reaction was carried out under anhydrous conditions in refluxing diethyl ether using six equivalents of hydride with respect to diallene formation. The reaction was monitored by TLC and when quenched and worked up after $1 \mathrm{~h}$, three products were detected and subsequently isolated by flash chromatography. All the products had the same molecular weight as the expected product, but 
their IR spectra did not show any absorption in the allene region (1955-1925 $\mathrm{cm}^{-1}$ ) [28], which rules out that diallene formation had occurred. However, absorptions in the $1680-1620 \mathrm{~cm}^{-1}$ and $840-790 \mathrm{~cm}^{-1}$ regions indicate the presence of trisubstituted alkenes [28], and this requires the presence of a $C-C$ triple bond to be compatible with the determined molecular weight. Considering the symmetry of the starting material, the triple bond would be expected to be symmetrically substituted, and this would explain the absence of an absorption in the $2270-2120 \mathrm{~cm}^{-1}$ region [28]. In order to determine whether this was a reasonable assumption, the Raman spectrum of $\mathbf{2}$ was recorded. To our satisfaction, a strong absorption appeared at $2186 \mathrm{~cm}^{-1}$. This observation made the structure elucidation fairly straightforward when ${ }^{1} \mathrm{H}$ - and ${ }^{13} \mathrm{C}$-NMR data were considered, and the three compounds, isolated in $26 \%, 34 \%$ and $3 \%$ yield, were proved to be the $(Z, Z),(E, Z)$ and $(E, E)$ isomers of 1,1,2,7,8,8-hexaethoxyocta-2,6-dien-4-yne, 2a, $\mathbf{2 b}$ and $\mathbf{2 c}$, respectively.

The stereoisomers could be differentiated by a detailed study of the 3.4-5.5 ppm region of their proton NMR spectra, shown in Figure 1. The $(Z, Z)$ and $(E, E)$ isomers both exhibit $C 2$ symmetry, and the methine protons at C-1 and C-8 consequently have the same chemical shift, as do the olefinic protons at C-3 and C-6, and the methylene groups in the ethoxy groups attached to C-2 and C-7. These isomers will therefore show the same number of signals in the 3.4-5.5 ppm region. The asymmetry of the corresponding $(E, Z)$ isomer results in twice the number of signals in this region, giving rise to the middle spectrum in Figure 1, which interestingly is almost identical to that obtained when the top and the bottom spectra are combined.

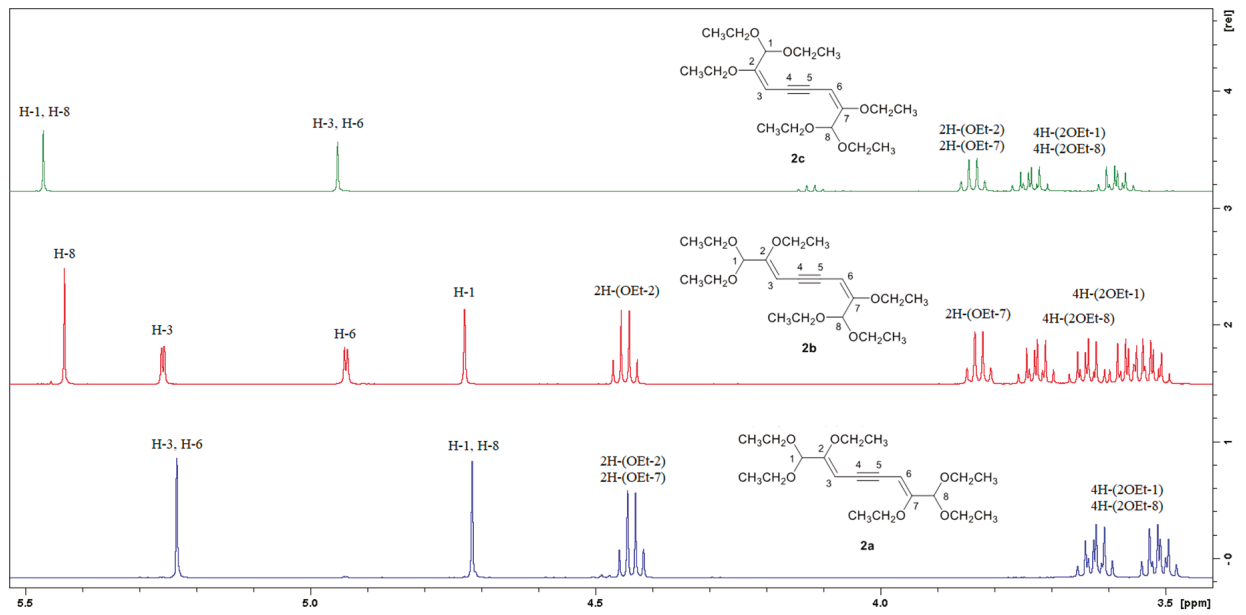

Figure 1. The 5.5-3.4 ppm region of the ${ }^{1} \mathrm{H}-\mathrm{NMR}$ spectra of the three isomers of 2 . The signals in the 4.6-3.4 ppm region are due to the methylene moieties in the ethoxy groups attached to C-1, C-2, C-7, and C-8. To denote the two hydrogen atoms in the methylene group in EtO attached to C-n, the following notation is used: $2 \mathrm{H}-(\mathrm{OEt}-\mathrm{n})$.

The assignments of the proton spectra of $\mathbf{2 a}, \mathbf{2} \mathbf{b}$ and $\mathbf{2 c}$ shown in Figure 1 were arrived at by using information harvested from the DEPT-90, DEPT-135, HSQC, and HMBC spectra of each of the isomers. The DEPT and HSQC spectra confirmed the presence of the methyl, methylene, and methine protons, the olefinic $\mathrm{CH}$ groups, and the quaternary carbon atoms, whereas the HMBC spectrum showed the correlation between hydrogen and carbon atoms two and three bonds apart. The HMBC spectra can therefore be used to assign the H-1, H-8 and H-3, H-6 singlets, which is clearly illustrated by the spectrum for 2c (Figure S13). In this spectrum, the proton singlet at $5.47 \mathrm{ppm}$ correlates through three bonds with the methylene carbon atoms at $63.1 \mathrm{ppm}$ due to the ethoxy groups at C-1 and C-8 and through two bonds with the quaternary carbon atoms at $161.9 \mathrm{ppm}$ (C-2 and C-7); thus, this proton 
singlet is due to $\mathrm{H}-1$ and $\mathrm{H}-8$. This assignment is further supported by correlations between the proton singlet at $4.95 \mathrm{ppm}$ and the olefinic quaternary carbons at $161.9 \mathrm{ppm}(\mathrm{C}-2$ and $\mathrm{C}-7)$ and the acetal carbon atoms at $98.4 \mathrm{ppm}(\mathrm{C}-1$ and $\mathrm{C}-8)$.

In order to differentiate between the $(Z, Z)$ and $(E, E)$ isomers, the chemical shifts of the methine hydrogen at C-1 (and C-8) and the methylene protons in the ethoxy group attached to C-2 (and C-7) in the two isomers were compared. Due to the anisotropy of the triple bond attached to C-3 (and C-6), protons cis to the acetylenic moiety will be deshielded, whereas those in trans position will be shielded [29]. Thus, since the methylene quartet in the bottom spectrum appears at a lower field than in the top spectrum, $4.44 \mathrm{ppm}$ compared to $3.84 \mathrm{ppm}$, and the methine singlet in the bottom spectrum appears at a higher field than in the top spectrum, $4.72 \mathrm{ppm}$ compared to $5.47 \mathrm{ppm}$, the bottom spectrum belongs to $(Z, Z)-2(2 \mathbf{a})$ and the top spectrum to $(E, E)-\mathbf{2}(\mathbf{2} \mathbf{c})$.

The complete absence in the reaction mixture of the expected diallene and any of the by-products this cumulene conceivably could have given under the reaction and work-up conditions [30-33] indicates that $\mathbf{1}$ is not attacked initially at C-4 (and C-5). A likely explanation for this is that the 1,1,2,2-tetraethoxyethyl groups attached to the ends of the buta-1,3-diyne moiety render its termini relatively electropositive and make initial attack of C-3 (and C-6) more favorable. It is also conceivable that coordination of one or several oxygen atoms to species derived from LAH at some stage will facilitate the same sort of attack (see Scheme 2). This leads to formation of a pent-1,2,3,4-tetraene derivative (3), which is unstable in the presence of a hydride source and reacts quickly to give dienyne 1,1,2,7,8,8-hexaethoxyocta-2,6-dien-4-yne (2) (Scheme 2). Thus, the two hydrogens replacing the two ethoxy groups in the conversion of 1 to 2 are attached by hydride attack in a $S_{N} 2^{\prime}$ fashion, not by reaction with water during the quenching of the reaction. In accordance with this, quenching using $\mathrm{D}_{2} \mathrm{O}$ did not lead to deuterium incorporation in 2 . Traces of any intermediate were not detected, neither spectroscopically nor by TLC.

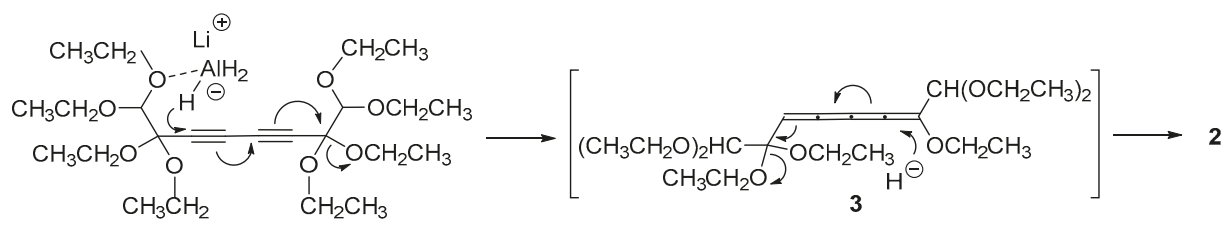

Scheme 2. Possible mechanism for formation of dienyne 2 from diyne $\mathbf{1}$ by two subsequent $\mathrm{S}_{\mathrm{N}} 2^{\prime}$ reactions with hydride as a nucleophile.

\section{Materials and Methods}

\subsection{General}

The chemicals were obtained from commercial suppliers and used without further purification. Thin-layer chromatography (TLC) was performed using pre-coated aluminum TLC plates (Alugram, $0.20 \mathrm{~mm}$ Silica Gel $60 \mathrm{~F}_{254}$ ) and eluting with a 95:5 mixture of hexanes and ethyl acetate. The $\mathrm{R}_{f}$ values were determined after the liquid front had migrated $4-5 \mathrm{~cm}$. Visualization of the chromatograms was done with phosphomolybdic acid $\left.\left(\mathrm{NH}_{4}\right)_{4} \mathrm{MoO}_{4} \cdot 4 \mathrm{H}_{2} \mathrm{O}\right)$ in ethanol followed by heating. Flash-column chromatography (FC) was performed manually using Silica Gel from Fluka Analytical (230-400 mesh) and eluting with a 80:20 mixture of hexanes and ethyl acetate. NMR spectra were recorded on a Bruker Biospin AV500 instrument ( $500 \mathrm{MHz}$ for ${ }^{1} \mathrm{H}, 125 \mathrm{MHz}$ for ${ }^{13} \mathrm{C}$ ) in $\mathrm{CDCl}_{3}$ as solvent, using the solvent peaks as references in both ${ }^{1} \mathrm{H}$ - and ${ }^{13} \mathrm{C}$-NMR spectra (7.26 and $77.16 \mathrm{ppm}$, respectively). The chemical shifts are reported in ppm, the coupling constants $(J)$ in $\mathrm{Hz}$, and the multiplicity is given as $\mathrm{s}$ (singlet), d (doublet), $\mathrm{t}$ (triplet), and $\mathrm{m}$ (multiplet). Infrared (IR) spectra were recorded on a Nicolet Protege 460 FT-IR spectrophotometer with an attenuated total reflectance (ATR) unit attached. Samples were analyzed neat on a ZnSe crystal, and absorption peaks are reported in wavenumbers $\left(\mathrm{cm}^{-1}\right)$ and characterized as strong (s), medium (m), weak (w) and broad (br). Raman spectra were recorded on a 
Kaiser RamanRxn1 ${ }^{\mathrm{TM}}$ instrument operated under standard conditions. High-resolution mass spectra (HRMS) were obtained on a Jeol AccuTOFTM mass spectrometer operated in the ESI mode under standard conditions.

\subsection{Reduction of 1,1,2,2,7,7,8,8-Octaethoxyocta-3,5-diyne (1)}

A two-necked, round-bottom flask, equipped with a magnetic stirring bar, a condenser with a $\mathrm{CaCl}_{2}$ tube, and a septum, was charged with dry diethyl ether $(6 \mathrm{~mL})$ and LAH $(0.099 \mathrm{~g}, 2.6 \mathrm{mmol})$. The suspension was cooled (ice/water) and a solution of $\mathbf{1}(0.399 \mathrm{~g}, 0.87 \mathrm{mmol})$ in dry diethyl ether $(3.0 \mathrm{~mL})$ was added dropwise with a syringe. The bath was removed, and the resulting mixture was stirred under reflux for $1 \mathrm{~h}$. The mixture was then added to some ice and when the ice had melted, a saturated solution of Rochelle salt was added. The hydrolysate was extracted with diethyl ether $(4 \times 10 \mathrm{~mL})$; the combined organic phases were dried $\left(\mathrm{Na}_{2} \mathrm{SO}_{4}\right)$, filtered, and concentrated under vacuum on a rotary evaporator. The residue contained three products (TLC), which were isolated by flash chromatography and proved to be isomers of 1,1,2,7,8,8-hexaethoxyocta-2,6-dien-4-yne (2) based on the following spectroscopic and spectrometric data.

(Z,Z)-1,1,2,7,8,8-Hexaethoxyocta-2,6-dien-4-yne (2a): Yellowish liquid (0.090 g, 26\%); $R_{\mathrm{f}} 0.48$; FT-IR (film): $v_{\max } 2976(\mathrm{~s}), 2930(\mathrm{~m}), 2883(\mathrm{~m}), 2171(\mathrm{w}), 1649(\mathrm{~m}), 1621(\mathrm{~m}), 1180(\mathrm{~s}), 1110(\mathrm{~s}), 1049(\mathrm{~s}), 913(\mathrm{~s}), 841$ $(\mathrm{m}), 793(\mathrm{~m}) \mathrm{cm}^{-1} ;{ }^{1} \mathrm{H}-\mathrm{NMR}\left(\mathrm{CDCl}_{3}, 500 \mathrm{MHz}\right): \delta 5.23\left(\mathrm{~s}, 2 \mathrm{H}, 2 \mathrm{CH}(\mathrm{OEt})_{2}\right), 4.72(\mathrm{~s}, 2 \mathrm{H}, 2-\mathrm{CH}=), 4.44(\mathrm{q}$, $\left.4 \mathrm{H}, J=7.0 \mathrm{~Hz}, 2 \mathrm{OCH}_{2} \mathrm{CH}_{3}\right), 3.65-3.48\left(\mathrm{~m}, 8 \mathrm{H}, 4 \mathrm{OCH}_{2} \mathrm{CH}_{3}\right), 1.30\left(\mathrm{t}, 6 \mathrm{H}, J=7.0 \mathrm{~Hz}, 2 \mathrm{OCH}_{2} \mathrm{CH}_{3}\right), 1.21$ $\left(\mathrm{t}, 12 \mathrm{H}, J=7.0 \mathrm{~Hz}, 4 \mathrm{OCH}_{2} \mathrm{CH}_{3}\right) \mathrm{ppm} ;{ }^{13} \mathrm{C} \mathrm{NMR}\left(\mathrm{CDCl}_{3}, 125 \mathrm{MHz}\right): \delta 158.6(2 \mathrm{C}), 100.1(2 \mathrm{C}), 88.4(2 \mathrm{C})$, $85.7(2 \mathrm{C}), 66.6(2 \mathrm{C}), 62.0(4 \mathrm{C}), 15.6(2 \mathrm{C}), 15.3(4 \mathrm{C}) \mathrm{ppm}$; HRMS Calcd for $\mathrm{C}_{20} \mathrm{H}_{34} \mathrm{O}_{6} \mathrm{Na}^{+}[\mathrm{M}+\mathrm{Na}]^{+} \mathrm{m} / \mathrm{z}$ 393.22531, found $m / z 393.22555$.

(E,Z)-1,1,2,7,8,8-Hexaethoxyocta-2,6-dien-4-yne (2b): Yellowish liquid (0.110 g, 34\%); $R_{\mathrm{f}} 0.36$; FT-IR (film): $v_{\max } 2976(\mathrm{~s}), 2930(\mathrm{~m}), 2882(\mathrm{~m}), 2187(\mathrm{w}), 1641(\mathrm{~m}), 1612(\mathrm{~m}), 1252(\mathrm{~s}) .1110(\mathrm{~s}), 1049(\mathrm{~s}), 839(\mathrm{~m}), 793$ (m) $\mathrm{cm}^{-1} ;{ }^{1} \mathrm{H}-\mathrm{NMR}\left(\mathrm{CDCl}_{3}, 500 \mathrm{MHz}\right): \delta 5.43\left(\mathrm{~s}, 1 \mathrm{H}, \mathrm{CH}(\mathrm{OEt})_{2}\right), 5.26(\mathrm{~d}, 1 \mathrm{H}, J=2.6 \mathrm{~Hz},-\mathrm{CH}=), 4.94(\mathrm{~d}$, $1 \mathrm{H}, J=2.6 \mathrm{~Hz},-\mathrm{CH}=), 4.72\left(\mathrm{~s}, 1 \mathrm{H}, \mathrm{CH}(\mathrm{OEt})_{2}\right), 4.45\left(\mathrm{q}, 2 \mathrm{H}, J=7.0 \mathrm{~Hz}, \mathrm{OCH}_{2} \mathrm{CH}_{3}\right), 3.83(\mathrm{q}, 2 \mathrm{H}, J=7.0 \mathrm{~Hz}$, $\left.\mathrm{OCH}_{2} \mathrm{CH}_{3}\right), 3.76-3.49\left(\mathrm{~m}, 8 \mathrm{H}, 4 \mathrm{OCH}_{2} \mathrm{CH}_{3}\right), 1.36\left(\mathrm{t}, 3 \mathrm{H}, J=7.0 \mathrm{~Hz}, \mathrm{OCH}_{2} \mathrm{CH}_{3}\right), 1.31(\mathrm{t}, 3 \mathrm{H}, J=7.0 \mathrm{~Hz}$, $\left.\mathrm{OCH}_{2} \mathrm{CH}_{3}\right), 1.24\left(\mathrm{t}, 6 \mathrm{H}, J=7.0 \mathrm{~Hz}, 2 \mathrm{OCH}_{2} \mathrm{CH}_{3}\right), 1.22\left(\mathrm{t}, 6 \mathrm{H}, J=7.0 \mathrm{~Hz}, 2 \mathrm{OCH}_{2} \mathrm{CH}_{3}\right) \mathrm{ppm} ;{ }^{13} \mathrm{C} \mathrm{NMR}$ $\left(\mathrm{CDCl}_{3}, 125 \mathrm{MHz}\right): \delta 162.2(1 \mathrm{C}), 158.4(1 \mathrm{C}), 100.1$ (1C), 98.4 (1C), 88.1 (1C), 87.7 (1C), 85.9 (1C), 84.5 (1C), 66.5 (1C), 64.1 (1C), 63.2 (2C), 62.1 (2C), 15.6 (1C), 15.32 (2C), 15.27 (2C), 14.3 (1C) ppm; HRMS Calcd for $\mathrm{C}_{20} \mathrm{H}_{34} \mathrm{O}_{6} \mathrm{Na}^{+}[\mathrm{M}+\mathrm{Na}]^{+} \mathrm{m} / \mathrm{z} 393.22531$, found $m / z$ 393.22566.

(E,E)-1,1,2,7,8,8-Hexaethoxyocta-2,6-dien-4-yne (2c): Yellowish liquid $(0.009 \mathrm{~g}, 3 \%) ; R_{\mathrm{f}}=0.20$; FT-IR (film): $v_{\max } 2976(\mathrm{~s}), 2930(\mathrm{~m}), 2881(\mathrm{~m}), 2172(\mathrm{w}), 1626(\mathrm{~s}), 1254(\mathrm{~s}), 1198(\mathrm{~s}), 1110(\mathrm{~s}), 1048(\mathrm{~s}), 956(\mathrm{~s})$, $794(\mathrm{~s}) \mathrm{cm}^{-1} ;{ }^{1} \mathrm{H}-\mathrm{NMR}\left(\mathrm{CDCl}_{3}, 500 \mathrm{MHz}\right): \delta 5.47\left(\mathrm{~s}, 2 \mathrm{H}, 2 \mathrm{CH}(\mathrm{OEt})_{2}\right), 4.95(\mathrm{~s}, 2 \mathrm{H}, 2-\mathrm{CH}=), 3.84(\mathrm{q}, 4 \mathrm{H}$, $\left.J=7.0 \mathrm{~Hz}, 2 \mathrm{OCH}_{2} \mathrm{CH}_{3}\right), 3.77-3.55\left(\mathrm{~m}, 8 \mathrm{H}, 4 \mathrm{OCH}_{2} \mathrm{CH}_{3}\right), 1.37\left(\mathrm{t}, 6 \mathrm{H}, J=7.0 \mathrm{~Hz}, 2 \mathrm{OCH}_{2} \mathrm{CH}_{3}\right), 1.25$ $\left(\mathrm{t}, 12 \mathrm{H}, J=7.1 \mathrm{~Hz}, 4 \mathrm{OCH}_{2} \mathrm{CH}_{3}\right) \mathrm{ppm} ;{ }^{13} \mathrm{C} \mathrm{NMR}\left(\mathrm{CDCl}_{3}, 125 \mathrm{MHz}\right): \delta 161.9(2 \mathrm{C}), 98.4(2 \mathrm{C}), 87.3(2 \mathrm{C})$, 84.4 (2C), $64.1(2 \mathrm{C}), 63.1(4 \mathrm{C}), 15.3(4 \mathrm{C}), 14.4(2 \mathrm{C}) \mathrm{ppm}$. HRMS Calcd for $\mathrm{C}_{20} \mathrm{H}_{34} \mathrm{O}_{6} \mathrm{Na}^{+}[\mathrm{M}+\mathrm{Na}]^{+} \mathrm{m} / \mathrm{z}$ 393.22531, found $m / z 393.22567$.

Supplementary Materials: The following are available online, Figures S1-S9: IR, ${ }^{1} \mathrm{H}-\mathrm{NMR}$, and ${ }^{13} \mathrm{C}-\mathrm{NMR}$ spectra of compounds 2a, 2b, and 2c; Figures S10-S13: DEPT-90, DEPT-135, HSQC, and HMBC spectra of 2c; Figure S14: Raman spectrum of a mixture of compounds $2 \mathbf{a}, \mathbf{2} \mathbf{b}$, and $\mathbf{2 c}$.

Author Contributions: Conceptualization, L.K.S.; methodology, investigation, S.M.P.; writing-original draft preparation, L.K.S.; writing - review and editing, L.K.S. and S.M.P.; supervision, project administration, funding acquisition, L.K.S. All authors have read and agreed to the published version of the manuscript.

Funding: This research was funded by University of Bergen, the Munin Foundation, and Norges Forskningsråd (Research Council of Norway).

Acknowledgments: We thank Bjarte Holmelid (University of Bergen) for technical assistance. Valuable comments from the reviewers are also highly appreciated.

Conflicts of Interest: The authors declare no conflict of interest. 


\section{References}

1. Sydnes, L.K. Formation of Acetylenes by Ring Opening of 1,1,2-Trihalocyclopropanes. Eur. J. Org. Chem. 2000, 3511-3518. [CrossRef]

2. Kvernenes, O.H.; Sydnes, L.K. Synthesis of 2-Chloroacrolein Diethyl Acetal (2-Chloroprop-2-enal, Diethyl Acetal. Org. Synth. 2005, 83, 184-192.

3. Sydnes, L.K.; Holmelid, B.; Kvernenes, O.H.; Sandberg, M.; Hodne, M.; Bakstad, E. Synthesis and some chemical properties of 3,3,4,4-tetraethoxybut-1-yne. Tetrahedron 2007, 63, 4144-4148. [CrossRef]

4. Sydnes, L.K.; Valdersnes, S. Recent advances in the synthesis of carbohydrate analogues. Pure Appl. Chem. 2007, 79, 2137-2142. [CrossRef]

5. Sydnes, L.K.; Holmelid, B.; Myagmasuren, S.; Hanstein, M. New regiospecific synthesis of tri- and tetrasubstituted furans. J. Org. Chem. 2009, 74, 3430-3443. [CrossRef]

6. Sydnes, L.K.; Isanov, R.; Sengee, M.; Livi, F. Regioselective Synthesis of Tetra-Substituted Furans. Synth. Commun. 2013, 43, 2898-2906. [CrossRef]

7. Erdenebileg, U.; Høstmark, I.; Polden, K.; Sydnes, L.K. Synthesis and reactivity of 4-amino-sustituted furfurals. J. Org. Chem. 2014, 79, 1213-1221. [CrossRef]

8. Farooq, T.; Haug, B.E.; Sydnes, L.K.; Törnroos, K.W. 1,3-Dipolar cycloaddition of benzyl azide to two highly functionalized alkynes. Monatshefte Chem. 2012, 143, 505-512. [CrossRef]

9. Sydnes, L.K.; Kvernenes, O.H.; Valdersnes, S. From 3,3,4,4-tetraethoxybutyne to carbohydrate mimics. Pure Appl. Chem. 2005, 77, 119-130. [CrossRef]

10. Valdersnes, S.; Sydnes, L.K. Preparation of 2-ethoxy-3-hydroxy-4-(perfluoroalkyl)tetrahydropyran derivatives from substituted 4-ethoxybut-3-en-1-ols. Eur. J. Org. Chem. 2009, 5816-5831. [CrossRef]

11. Sengee, M.; Sydnes, L.K. Specific conjugate addition to $\alpha, \beta$-acetylenic ketones. Synthesis 2011, 23, 3899-3907. [CrossRef]

12. Valdersnes, S.; Apeland, I.; Flemmen, G.; Sydnes, L.K. Toward the synthesis of modified carbohydrates by conjugate addition of propane-1,3-dithiol to $\alpha, \beta$-unsaturated ketones. Helv. Chim. Acta 2012, 95, 2099-2122. [CrossRef]

13. Leiren, M.K.; Valdersnes, S.; Sydnes, L.K. Selective transformations of a diprotected 2-oxo-butanedial. Helv. Chim. Acta 2013, 96, 1841-1850. [CrossRef]

14. Nes, I.; Sydnes, L.K. Formation of N-heterocycles from 1,1-diethoxy-5-hydroxyalk-3-yn-2-ones. Synthesis 2014, 47, 89-94.

15. Isanov, R.; Holmelid, B.; Törnroos, K.W.; Sydnes, L.K. Synthesis of (E)-1,1-diethoxy-3-(3-hydroxy-3-arylfuro [2,3-b]quinoxalin-2(3H)-ylidene)propan-2-ones via acid-catalyzed stereoselective 5-Exo-Dig cyclization. J. Heterocycl. Chem. 2015, 52, 711-718. [CrossRef]

16. Holmelid, B.; Sydnes, L.K. Synthesis of 1,1,2,2,7,7,8,8-Octaethoxyocta-3,5-diyne. Molbank 2015, 2015, M840. [CrossRef]

17. Nantz, M.H.; Bender, D.M.; Janaki, S. A convenient terminal allene synthesis from propargylic acetates. Synthesis 1993, 6, 577-578. [CrossRef]

18. Haces, A.; Van Kruchten, E.M.G.A.; Okamura, W.H. On the stereochemistry of organocopper mediated conversion of propargylic esters to allenes. Israel J. Chem. 1985, 26, 140-146. [CrossRef]

19. Elsevier, C.J.; Stehouwer, P.M.; Westmijze, H.; Vermeer, P. Anti-stereoselectivity in the palladium(0)-catalyzed conversion of propargylic esters into allenes by phenylzinc chloride. J. Org. Chem. 1983, 48, 1103-1105. [CrossRef]

20. Mae, M.; Hong, J.A.; Xu, B.; Hammond, G.B. Highly Regioselective Synthesis of gem-Difluoroallenes through Magnesium Organocuprate SN2' Substitution. Org. Lett. 2006, 8, 479-482. [CrossRef]

21. Soler-Yanes, R.; Arribas-Alvarez, I.; Guisan-Ceinos, M.; Bunuel, E.; Cardenas, D.J. NiI Catalyzes the Regioselective Cross-Coupling of Alkylzinc Halides and Propargyl Bromide to Allenes. Chem. Eur. J. 2017, 23, 1584-1590. [CrossRef] [PubMed]

22. Kalli, M.; Landor, P.D.; Landor, S.R. Allenes. XVII. Reaction of dialkyl(lithio)copper reagents with 1-bromoallenes, 1-iodoallenes, and 3-chloro-1-alkynes. J. Chem. Soc. Perkin Trans. 1 1973, 1347-1349. [CrossRef]

23. Jacobs, T.L.; Wilcox, R.D. Dehalogenation of Propargyl and Allenyl Halides. II. J. Am. Chem. Soc. 1964, 86, 2240-2247. [CrossRef] 
24. Cowie, J.S.; Landor, P.D.; Landor, S.R. Allenes. XIV. Preparation of $\alpha$-allenic alcohols from the mono-O-(tetrahydropyran-2-yl) derivatives of 1,4-butynediols. J. Chem. Soc. Perkin Trans. 1 1973, 720-724. [CrossRef]

25. Alexakis, A.; Marek, I.; Mageney, P.; Normant, J.F. Mechanistic Aspects on the Formation of Chiral Allenes from Propargylic Ethers and Organocopper Reagents. J. Am. Chem. Soc. 1990, 112, 8042-8047. [CrossRef]

26. Alexakis, A. Stereochemical Aspects on the Formation of Chiral Allenes from Propargylic Ethers and Epoxides. Pure Appl. Chem. 1992, 64, 387-392. [CrossRef]

27. Boreux, A.; Lonca, G.H.; Riant, O.; Gagosz, F. Synthesis of Trifluoromethylallenes by Gold-Catalyzed Rearrangement Propargyl Benzyl Ethers. Org. Lett. 2016, 18, 5162-5165. [CrossRef]

28. Bellamy, L.J. The Infrared Spectra of Complex Molecules, 2nd ed.; Chapman and Hall: London, UK, 1980; Volume 2.

29. Becker, E.D. High Resolution NMR: Theory and Applications, 3rd ed.; Academic Press: San Diego, CA, USA, 2000; pp. 83-117.

30. Skatteboel, L.; Solomon, S. Thermally induced reactions of some novel allenes. J. Am. Chem. Soc. 1965, 87, 4506-4513. [CrossRef]

31. Mühlstädt:, M.; Graefe, J. Synthesen cycloaliphatischer Ketone aus Cyclodecatrien-(1,5,9). II. Herstellung von Cyclononen durch Hydratisierung cyclischer Allene. Chem. Ber. 1967, 100, 223-227. [CrossRef]

32. Hoff, S.; Brandsma, L.; Arens, J.F. Conversions of allenyl ethers. Rec. Trav. Chim. Pay-Bas 1968, 87, 1179-1184. [CrossRef]

33. Pasto, D.J.; Kong, W. Study of the substituted vinylallene-methylenecyclobutene electrocyclic equilibria. Comparison with the butadiene-cyclobutene and bisallene-bismethylenecyclobutene electrocyclic equilibria. J. Org. Chem. 1989, 54, 4028-4033. [CrossRef]

(C) 2020 by the authors. Licensee MDPI, Basel, Switzerland. This article is an open access article distributed under the terms and conditions of the Creative Commons Attribution (CC BY) license (http://creativecommons.org/licenses/by/4.0/). 


\title{
$4^{\prime}$-(N-(Propan-1,2-dienyl)pyrrol-2-yl)-2,2' $6^{\prime}, 2^{\prime \prime}$-terpyridine
}

\author{
Jérôme Husson * and Laurent Guyard \\ Institut UTINAM UMR CNRS 6213, UFR Sciences et Techniques, Université de Bourgogne-Franche-Comté, \\ 16 Route de Gray, 25030 Besançon CEDEX, France; laurent.guyard@univ-fcomte.fr \\ * Correspondence: jerome.husson@univ-fcomte.fr; Tel.: +33-3-81666291
}

Received: 5 March 2020; Accepted: 10 June 2020; Published: 10 June 2020

Abstract: A new pyrrole-substituted terpyridine derivative that possesses an allene moiety was obtained as an "unexpected" sole product during an attempt to alkylate the N-atom of pyrrole with propargyl bromide in order to obtain an alkyne-functionalized terpyridine.

Keywords: ligand; pyridine derivatives; allenic compounds; $N$-alkylation

\section{Introduction}

Terpyridine ligands (terpy) and their complexes have been widely studied [1]. This can be easily explained by the huge number of terpyridine derivatives that can be obtained by varying the substitution pattern of the ligand as well as the nature of the complexed metal. In particular, terpyridines that contain a five membered heterocycle, such as furan [2] or thiophene [3], have attracted a lot of attention. In fact, they can be used as intermediates in the preparation of materials for solar cells [4] or nanoparticles [5], as biological probes [6], as ligands in catalysis [7], as antimicrobial agents [8], as electrochromic materials [9] or as chromophores [10], to name just a few applications. Although a little less studied, terpyridines that include a pyrrole ring have also been a subject of interest. For example, such terpyridines have been used for the preparation of cytotoxic molecules [11], for application in OLED (organic light emitting diodes) [12] or sensor devices [13] or for the preparation of catalytic materials [14]. Thus, the preparation of terpyridine derivatives that contain a functionalized pyrrole is of interest in the fields of both organic synthesis and material science. This article describes how pyrrole-containing terpyridine $\mathbf{1}$ was obtained as an unexpected product during attempts to prepare compound 2 (Figure 1), which features an alkyne chain for possible future functionalization [15].<smiles>C=C=Cn1cccc1-c1cc(-c2ccccn2)nc(-c2ccccn2)c1</smiles><smiles>C#CCn1cccc1-c1cc(-c2ccccn2)nc(-c2ccccn2)c1</smiles>

Figure 1. Structures of terpyridine compounds (1) and (2).

\section{Results and Discussion}

The synthetic approach towards molecule 2 relies on the $N$-alkylation of the pyrrole moiety of $4^{\prime}$-(pyrrol-2-yl)-2,2':6', 2"'-terpyridine (3) with propargyl bromide (Figure 2), applying a protocol that has been described for the preparation of $\mathrm{N}$-alkyl terpyridine pyrroles [16]. At the end of the reaction, 
a single product was noticed by TLC. This product was easily separated from the starting material by flash chromatography, but ${ }^{1} \mathrm{H}$ NMR did not agree with the structure of 2 .<smiles>c1ccc(-c2cc(-c3ccc[nH]3)cc(-c3ccccn3)n2)nc1</smiles><smiles>CCC(CC)C(Br)CC(C)(C)CBr</smiles>

Figure 2. Synthetic pathway that afforded compound 1 .

Instead, structure 1 was coherent with ${ }^{1} \mathrm{H}$ NMR. In particular, the spectrum exhibits the signals for the allenic protons. In fact, a triplet is observed at $7.14 \mathrm{ppm}(J=6.4 \mathrm{~Hz})$. This signal accounts for the allenic proton e (Figure 3). In addition, a doublet is observed at $5.50 \mathrm{ppm}(J=6.4 \mathrm{~Hz}$ ) for the allenic protons $\mathrm{g}$. These multiplicities and chemical shifts are in accordance with those reported for other allene-functionalized pyrroles [17-19].

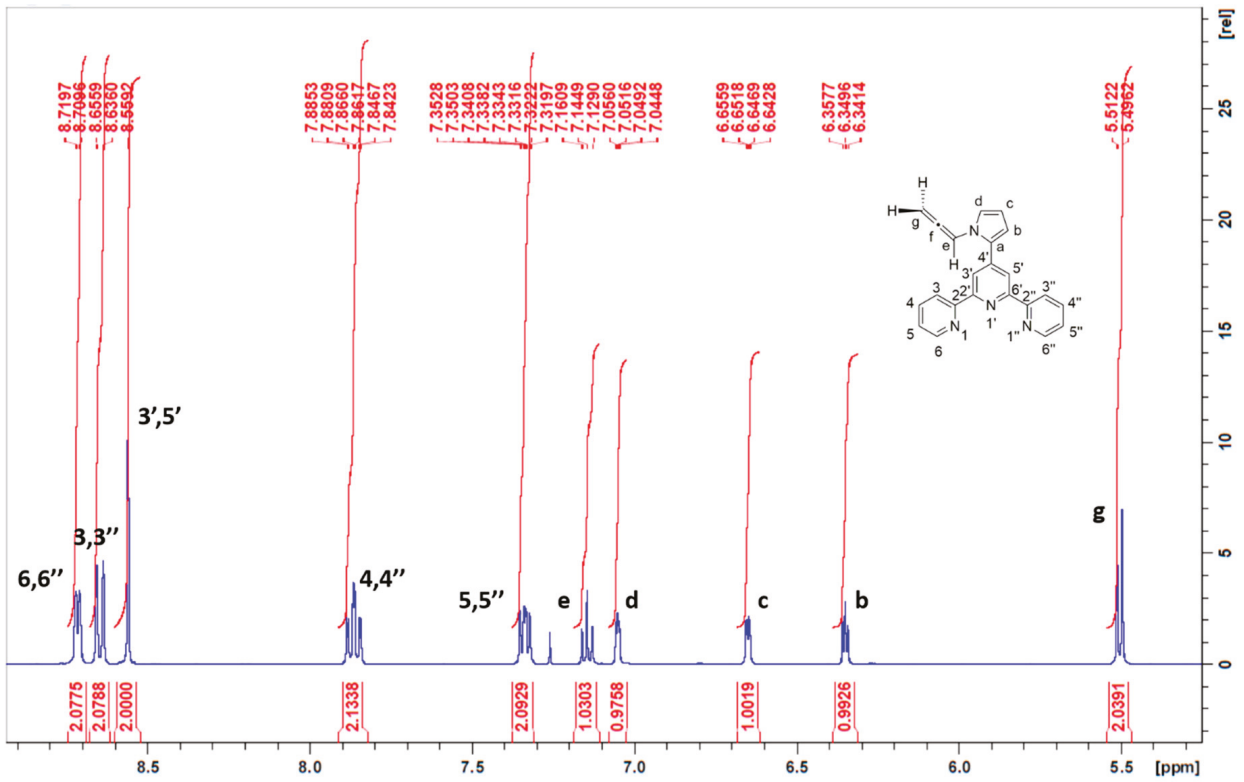

Figure $3 .{ }^{1} \mathrm{H}$ NMR spectra of compound $\mathbf{1}$ (inset: structure and atom numbering of $\mathbf{1}$ ).

All other signals arising from the terpyridine and the pyrrole parts of the molecule are present. Additionally, the structure of $\mathbf{1}$ was further confirmed by Supplementary Materials ${ }^{13} \mathrm{C}$ NMR, as well as by HR-MS. For instance, the ${ }^{13} \mathrm{C}$ NMR spectrum features 15 signals due to the symmetry of the molecule, while mass spectra exhibit the molecular ion peak at 337.14466 (calc. for $\left[\mathrm{C}_{22} \mathrm{H}_{16} \mathrm{~N}_{4}+\mathrm{H}\right]^{+}: 337.14477$ ).

As pointed out in the above-mentioned literature, the formation of compound $\mathbf{1}$ is not so "unexpected". Nevertheless, no trace of alkyne 2 was noticed, while N-propargylation of pyrrole and indole derivatives under similar reaction conditions are described in the literature $[20,21]$. Therefore, the obtention of $\mathbf{1}$ as the sole product is "unexpected". 


\section{Materials and Methods}

All reagents were purchased from commercial suppliers and used as received. The 4'-(Pyrrol-2-yl)-2,2':6', 2"'-terpyridine (3) was prepared according to the literature [16]. A volume of $85 \%$ Potassium hydroxide pellets (VWR Chemicals, France) was powdered using a mortar and a pestle. Anhydrous DMSO and 80\% propargyl bromide solution in toluene were purchased from ACROS Organics (Geel, Belgium) and used as received. Flash chromatography was carried out on a Combiflash Rf+ Lumen (Teledyne ISCO, Lincoln, NE, USA) using a Redisep Rf neutral alumina column (Teledyne ISCO, Lincoln, NE, USA) with a hexane/ethyl acetate mixture (100:0 to 80:20 v:v) as eluent. The ${ }^{1} \mathrm{H}$ and ${ }^{13} \mathrm{C}$ NMR spectra were recorded on a Brucker AC 400 (Bruker, Wissembourg, France) at 400 and $100 \mathrm{MHz}$, respectively, using $\mathrm{CDCl}_{3}$ as a solvent. The melting point was recorded with a Stuart SMP 10 melting point apparatus (Bibby Sterilin, Stone, UK) and was uncorrected. HR-MS was recorded at Sayence SATT, Dijon, France.

$4^{\prime}$-(N-(Propan-1,2-dienyl)pyrrol-2-yl)-2,2':6',2"-terpyridine (1): Into a round bottomed flask, the powdered potassium hydroxide $(0.44 \mathrm{~g} ; 6.7 \mathrm{mmol})$ and dimethylsulfoxide $(35 \mathrm{~mL})$ were successively placed. The resulting suspension was stirred at room temperature under argon for 30 minutes. Then, $4^{\prime}$-(pyrrol-2-yl)-2,2' $: 6^{\prime}, 2^{\prime \prime}$-terpyridine (1.00 g; $3.35 \mathrm{mmol}$ ) was added and the red solution was stirred at room temperature under argon for $30 \mathrm{~min}$. Finally, propargyl bromide ( $80 \%$ solution in toluene, $0.50 \mathrm{~g}$; $3.36 \mathrm{mmol}$ ) was added and the reaction mixture was stirred at room temperature under argon for $24 \mathrm{~h}$. The solution was then poured onto water $(100 \mathrm{~mL})$ and a small amount of brine was added to ensure proper decantation. The aqueous layer was extracted with dichloromethane $(4 \times 25 \mathrm{~mL})$. The organic layers were combined, washed with brine $(100 \mathrm{~mL})$, dried over sodium sulfate and concentrated under vacuo. The crude was purified by flash chromatography. The title compound was obtained as a white solid (0.52-0.66 g) $\mathrm{Mp}=128{ }^{\circ} \mathrm{C} .{ }^{1} \mathrm{H} \mathrm{NMR}\left(\mathrm{CDCl}_{3}, 400 \mathrm{MHz}\right), \delta(\mathrm{ppm}): 8.71$ (d, $\left.2 \mathrm{H} \mathrm{H} 6,6{ }^{\prime \prime}, J=4.0 \mathrm{~Hz}\right)$, $8.65\left(\mathrm{~d}, 2 \mathrm{H}, \mathrm{H} 3,3^{\prime \prime}, J=8.0 \mathrm{~Hz}\right), 8.56\left(\mathrm{~s}, 2 \mathrm{H}, \mathrm{H3}^{\prime}, 5^{\prime}\right), 7.86\left(\mathrm{td}, 2 \mathrm{H}, \mathrm{H} 4,4^{\prime \prime}, J=7.7 \mathrm{~Hz}, J=1.7 \mathrm{~Hz}\right), 7.34$ (ddd, $\left.2 \mathrm{H}, \mathrm{H} 5,5^{\prime \prime}, J=7.4 \mathrm{~Hz}, J=4.8 \mathrm{~Hz}, J=1.0 \mathrm{~Hz}\right), 7.14(\mathrm{t}, 1 \mathrm{H}, \mathrm{He}, J=6.4 \mathrm{~Hz}), 7.05(\mathrm{dd}, 1 \mathrm{H}, \mathrm{Hd}, J=2.7 \mathrm{~Hz}$, $J=1.8 \mathrm{~Hz}), 6.65(\mathrm{dd}, 1 \mathrm{H}, \mathrm{Hc}, J=3.6 \mathrm{~Hz}, J=1.6 \mathrm{~Hz}), 6.35(\mathrm{t}, 1 \mathrm{H}, \mathrm{Hb}, J=3.2 \mathrm{~Hz}), 5.50(\mathrm{~d}, 1 \mathrm{H}, \mathrm{Hg}, J=6.4$ $\mathrm{Hz}) .{ }^{13} \mathrm{C} \mathrm{NMR}\left(\mathrm{CDCl}_{3}, 100 \mathrm{MHz}\right), \delta$ (ppm): 203.5, 156.2, 155.7, 149.2, 141.8, 136.8, 131.6, 123.8, 122.7, $121.3,119.9,112.4,110.4,98.7,87.2$. HR-MS: calc. for $\left[\mathrm{C}_{22} \mathrm{H}_{16} \mathrm{~N}_{4}+\mathrm{H}\right]^{+}$337.14477, found 337.14466.

\section{Conclusions}

A new pyrrole-containing terpyridine has been prepared and characterized. It features an allenic part that is linked via the $\mathrm{N}$-atom of the pyrrole nucleus. Considering the fact that allenes are valuable intermediates in the preparation of polymer [22] or molecular materials [23], and the impressive metal-coordination properties of terpyridine ligands [1], this new compound could be useful for the fabrication of novel metal-containing functional materials.

Supplementary Materials: The following are available online, ${ }^{1} \mathrm{H},{ }^{13} \mathrm{C},{ }^{1} \mathrm{H}-{ }^{1} \mathrm{H}$ COSY and ${ }^{1} \mathrm{H}-{ }^{13} \mathrm{C}$ HSQC NMR, HR-MS spectra of terpyridine 1.

Author Contributions: J.H. conceived and carried out the experiments, analyzed data and prepared the manuscript. L.G. analyzed data and contributed to manuscript preparation. All authors have read and agreed to the published version of the manuscript.

Funding: This research did not receive specific funding.

Conflicts of Interest: The authors declare no conflict of interest.

\section{References}

1. Schubert, U.S.; Hofmeier, H.; Newkome, G.R. Modern Terpyridine Chemistry; Wiley-VCH: Weinheim, Germany, 2006.

2. Husson, J.; Knorr, M. Syntheses and applications of furanyl-functionalised $2,2^{\prime}: 6^{\prime}, 2^{\prime \prime}$-terpyridines. Beilstein J. Org. Chem. 2012, 8, 379-389. [CrossRef] [PubMed]

3. Husson, J.; Knorr, M. 2,2' $: 6^{\prime}, 2^{\prime \prime}$-Terpyridines Functionalized with Thienyl Substituents: Synthesis and Applications. J. Heterocyclic Chem. 2012, 49, 453-478. [CrossRef] 
4. Dehaudt, J.; Husson, J.; Guyard, L. A more efficient synthesis of 4,4',4"'tricarboxy-2,2':6' $2^{\prime \prime}$-terpyridine. Green Chem. 2011, 13, 3337-3340. [CrossRef]

5. Momeni, B.Z.; Doustkhahvajari, F. Heteroleptic complexes of silver(I) featuring $4^{\prime}$-hydroxy and $4^{\prime}$-(2-furyl)-2,2' :6',2"-terpyridine: An easy route for synthesis of silver nanoparticles. Inorg. Chim. Acta. 2019, 487, 145-152. [CrossRef]

6. Shen, Y.; Shao, T.; Fang, B.; Du, W.; Zhang, M.; Liu, J.; Liu, T.; Tian, X.; Zhang, Q.; Wang, A.; et al. Visualization of mitochondrial DNA in living cells with super-resolution microscopy using thiophene-based terpyridine Zn(II) complexes. Chem. Commun. 2018, 54, 11288-11291. [CrossRef]

7. Husson, J.; Guyard, L. 4'-(5-Methylfuran-2-yl)-2,2':6',2"'-terpyridine: A New Ligand Obtained from a Biomass-Derived Aldehyde with Potential Application in Metal-Catalyzed Reactions. Molbank 2018, 2018, M1032. [CrossRef]

8. Njogu, E.M.; Martincigh, B.S.; Omondi, B.; Nyamori, V.O. Synthesis, characterization, antimicrobial screening and DNA binding of novel silver(I)-thienylterpyridine and silver(I)-furylterpyridine. Appl. Organomet. Chem. 2018, 32, E4554. [CrossRef]

9. Liang, Y.W.; Strohecker, D.; Lynch, V.; Holliday, B.J.; Jones, R.A. A Thiophene-Containing Conductive Metallopolymer Using an Fe(II) Bis(terpyridine) Core for Electrochromic Materials. ACS Appl. Mater. Interfaces 2016, 8, 34568-34580. [CrossRef]

10. Fernandes, S.S.M.; Besley, M.; Ciarrocchi, C.; Licchelli, M.; Raposo, M.M.M. Terpyridine derivatives functionalized with (hetero)aromatic groups and the corresponding Ru complexes: Synthesis and characterization as SHG chromophores. Dyes Pigment. 2018, 150, 49-58. [CrossRef]

11. Czerwinska, K.; Machura, B.; Kula, S.; Krompiec, S.; Erfurt, K.; Roma-Rodrigues, C.; Fernandes, A.R.; Shul'pina, L.; Ikonnikov, N.S.; Shul'pin, G.B. Copper(II) complexes of functionalized $2,2^{\prime}: 6^{\prime}, 2^{\prime \prime}$-terpyridines and 2,6-di(thiazol-2-yl)pyridine: Structure, spectroscopy, cytotoxicity and catalytic activity. Dalton Trans. 2017, 46, 9591-9604. [CrossRef]

12. Klemens, T.; Switlicka-Olszewska, A.; Machura, B.; Grucela, M.; Schab-Balcerzak, E.; Smolarek, K.; Mackowski, S.; Szlapa, A.; Kula, S.; Krompiec, S.; et al. Rhenium(I) terpyridine complexes—Synthesis, photophysical properties and application in organic light emitting devices. Dalton Trans. 2016, 45, 1746-1762. [CrossRef] [PubMed]

13. Naidji, B.; Husson, J.; Et Taouil, A.; Brunol, E.; Sanchez, J.-B.; Berger, F.; Rauch, J.-Y.; Guyard, L. Terpyridine-based metallopolymer thin films as active layer in ammonia sensor device. Synth. Met. 2016, 221, 214-219. [CrossRef]

14. Husson, J.; Guyard, L. A new and facile method for the functionalization of a Merrifield resin with terpyridines: Application as a heterogeneous catalyst for the synthesis of biaryls in environmentally friendly solvents. Green Process. Synth. 2016, 5, 331-336. [CrossRef]

15. Busemann, A.; Araman, C.; Flaspohler, I.; Pratesi, A.; Zhou, X.-Q.; van Rixel, V.H.S.; Siegler, M.A.; Messori, L.; van Kasteren, S.I.; Bonnet, S. Alkyne Functionalization of a Photoactivated Ruthenium Polypyridyl Complex for Click-Enabled Serum Albumin Interaction Studies. Inorg. Chem. 2020, 59, 7710-7720. [CrossRef] [PubMed]

16. Husson, J.; Guyard, L. Synthesis of new $4^{\prime}$-(N-alkylpyrrol-2-yl)-2,2':6', 2"'-terpyridines via N-alkylation of a pyrrole moiety. Heterocycl. Commun. 2015, 21, 199-202. [CrossRef]

17. Tarasova, O.A.; Brandsma, L.; Trofimov, B.A. Facile One-Pot Syntheses of 1-Allenylpyrroles. Synthesis 1993, 571-572. [CrossRef]

18. Tarasova, O.A.; Taherirastgar, F.; Verkruijsse, H.D.; Mal'kina, A.G.; Brandsma, L.; Trofimov, B.A. Metallation and functionalization of 1-allenylpyrrole. Recl. Trav. Chim. Pays Bas 1996, 115, 145-147. [CrossRef]

19. Duan, G.-J.; Ling, J.-B.; Wang, W.-P.; Luo, Y.-C.; Xu, P.-F. Organocatalytic formal [2+2] cycloaddition initiated by vinylogous Friedel-Crafts alkylation: Enantioselective synthesis of substituted cyclobutene derivatives. Chem. Commun. 2013, 49, 4625-4627. [CrossRef]

20. Zhao, Y.; Yuan, Y.; Xu, M.; Zheng, Z.; Zhang, R.; Li, Y. Selective synthesis of pyrrolo[1,2-a]azepines or 4,6-dicarbonyl indoles via tandem reactions of alkynone with pyrrole derivatives. Org. Biomol. Chem. 2017, 15, 6328-6332. [CrossRef]

21. Turnu, F.; Luridiana, A.; Cocco, A.; Porcu, S.; Frongia, A.; Sarais, G.; Secci, F. Catalytic Tandem Friedel-Crafts Alkylation/C4-C3 Ring-Contraction Reaction: An Efficient Route for the Synthesis of Indolyl Cyclopropanecarbaldehydes and Ketones. Org. Lett. 2019, 21, 7329-7332. [CrossRef] 
22. Endo, T.; Tomita, I. Novel Polymerization Methods for Allene Derivatives. Prog. Polym. Sci. 1997, 22, 565-600. [CrossRef]

23. Rivera-Fuentes, P.; Diederich, F. Allenes in Molecular Materials. Angew. Chem. Int. Ed. 2012, 51, $2818-2828$. [CrossRef] [PubMed]

(c) BY

(C) 2020 by the authors. Licensee MDPI, Basel, Switzerland. This article is an open access article distributed under the terms and conditions of the Creative Commons Attribution (CC BY) license (http://creativecommons.org/licenses/by/4.0/). 



\title{
Poly[1,3-Dimethyltetrahydropyrimidin-2(1H)-iminium [tri- $\mu_{2}$-cyanido- $\kappa^{6} \mathrm{C}: \mathrm{N}$-dicuprate(I)]]
}

\author{
Peter W. R. Corfield * and Joseph R. Dayrit \\ Chemistry Department, Fordham University, 441 East Fordham Road, Bronx, NY 10458, USA; \\ josephrdayrit@gmail.com \\ * Correspondence: pcorfield@fordham.edu; Tel.: +1-718-817-4454
}

Received: 2 November 2020; Accepted: 21 November 2020; Published: 24 November 2020

\begin{abstract}
The title compound contains a guanidinium cation that was unexpectedly found during X-ray single crystal analysis of a copper(I) cyanide network expected to contain protonated $N, N^{\prime}$-dimethyl-1,3-diaminopropane. The cation was presumably formed by reaction of the amine with cyanide ions in the aqueous sodium cyanide/copper cyanide mixtures used in the synthesis. The structure of the network solid features the guanidinium cation as a guest in an anionic two-dimensional polymeric framework with stoichiometry $\mathrm{Cu}_{2}(\mathrm{CN})_{3}{ }^{-}$. Confirmation of the structure was provided by analytical, thermal gravimetric and infrared data.
\end{abstract}

Keywords: copper; cyanide; network; guanidinium; unexpected iminium cation

\section{Introduction}

Polymeric copper(I) cyanide networks with guest cations continue to attract interest in light of their varied topologies and interesting physical properties, including chemiluminescence [1-5]. Our own work on $\mathrm{CuCN}$ complexes with amine bases, which initially sought to incorporate $\mathrm{Cu}^{\mathrm{II}}$ into these $\mathrm{Cu}^{\mathrm{I}}$ networks to provide neutral polymeric networks, has led to the characterization of both mixed valence $\mathrm{CuCN}$ compounds [6] and $\mathrm{Cu}^{\mathrm{I}} \mathrm{CN}$ networks with protonated amines as guests [7]. We report here the unexpected formation of the cyclic guanidinium complex poly[1,3-dimethyltetrahydropyrimidin-2(1H)-iminium [tri- $\mu_{2}$-cyanido- ${ }^{6} \mathrm{C}: \mathrm{N}$-dicuprate(I)]], $\mathbf{1}$, during an attempted synthesis of a copper cyanide polymer involving the diamine $N, N^{\prime}-1,3$-dimethyldiaminopropane. We had originally hoped for the formation of a crystalline mixed valence $\mathrm{Cu}^{\mathrm{I}} \mathrm{Cu}^{\mathrm{II}}$ cyanide polymer with the $\mathrm{Cu}^{\mathrm{II}}$ atoms stabilized by coordination of the bidentate amine ligands. The lack of color in the crystalline product indicated, however, that only $\mathrm{Cu}^{\mathrm{I}}$ was involved, so we suspected that the amine base would be present as its conjugate acid, to provide charge neutrality for an anionic $\mathrm{Cu}^{\mathrm{I}} \mathrm{CN}$ network, as in the structure reported in reference [6]. Single crystal $\mathrm{X}$-ray diffraction analysis, however, indicated that reaction of the diamine with cyanide had occurred with formation of a cyclic guanidinium cation. Lin et al. have reported a similar structure featuring the unexpected formation of the unsubstituted guanidinium cation [8]. We report here the crystal and molecular structure of $\mathbf{1}$, together with chemical analyses, thermal decomposition and infrared data.

\section{Results}

\subsection{Synthesis}

In a typical synthesis: $0.246 \mathrm{~g} \mathrm{NaCN}(5.0 \mathrm{mmol})$ was dissolved in $2-3 \mathrm{~mL}$ water, $0.279 \mathrm{~g}(3.1 \mathrm{mmol})$ $\mathrm{CuCN}$ was added and the mixture was stirred until all solid had dissolved. Separately, $0.431 \mathrm{~g}$ $N, N^{\prime}$-dimethyl-1,3-diaminopropane was dissolved in $2-3 \mathrm{~mL}$ water, and the solution was added slowly to the $\mathrm{NaCN} / \mathrm{CuCN}$ mixture. Colorless crystals were usually obtained within a week after filtration and water washing. 


\subsection{X-ray Structure}

The single crystal structure indicates a molecular formula $[\mathrm{LH}]\left[\mathrm{Cu}_{2}(\mathrm{CN})_{3}\right]$, where $\mathrm{LH}^{+}$is the cyclic guanidinium cation. The asymmetric unit showing thermal ellipsoids and atom numbering is given in Figure 1. The compound crystallizes as a two-dimensional $\mathrm{CuCN}$ network with the cations as guests; see Figure 2.

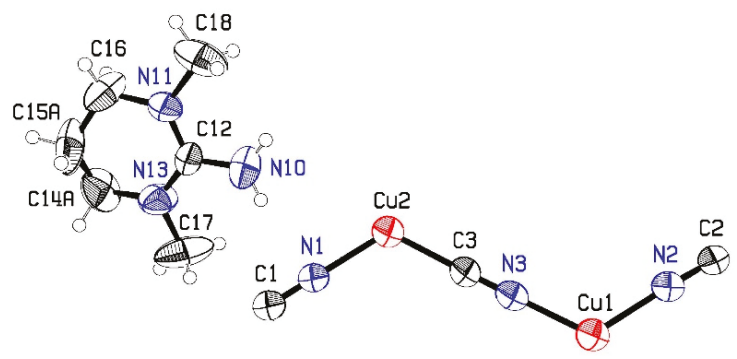

Figure 1. Asymmetric unit for compound 1, showing thermal ellipsoids with $50 \%$ probability. Only one orientation of the disordered CN groups is shown. C14 and C15 are also disordered; only the major component is shown.

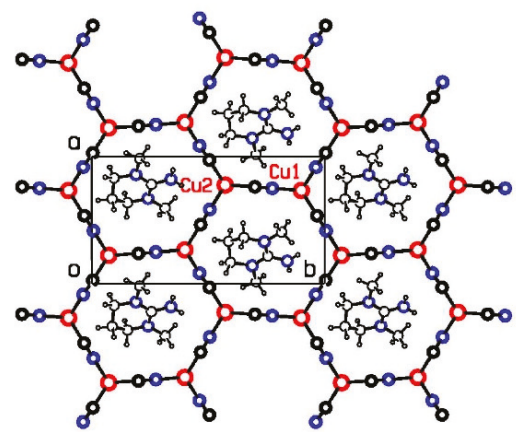

(a)

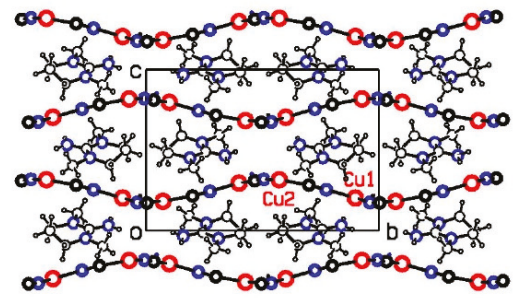

(b)

Figure 2. Packing Diagrams for 1. (a) One CuCN sheet and one cation layer, viewed down the c axis. (b) Sheet edges, viewed down the a axis. Nitrogen atoms are shown in blue, carbon and hydrogen atoms in black and copper atoms in red. $\mathrm{Cu} 1$ and $\mathrm{Cu} 2$ are labeled in their reference positions.

The $\mathrm{CuCN}$ sheets are made up of 18 -membered $\mathrm{CuCN}$ rings in a honeycomb arrangement. They are deformed from planarity, evidently in order to accommodate the guanidinium cations and in contrast to the planar sheets found in our earlier work on a similar structure [7]. The sheet deformation occurs with minimum deviation from ideal geometry for the trigonal planar $\mathrm{Cu}$ atoms: $\mathrm{Cu} 1$ and $\mathrm{Cu} 2$ lie only 0.035(2) and 0.073(2) $\AA$ above the plane through the three atoms bonded to them, and the angles at the $\mathrm{Cu}$ atoms differ from $120^{\circ}$ by at most $2.4(1)^{\circ}$. Bonding at the bridging $\mathrm{CN}$ groups deviates from linearity by an average of $4.1(1)^{\circ}$, with a maximum of $8.1(2)^{\circ}$.

The cation is the cyclic guanidinium cation shown in Figure 1 and not the expected conjugate acid of the base. The new cation appears to have been formed by an oxidation reaction between the cyanide ion and the diamine base: 


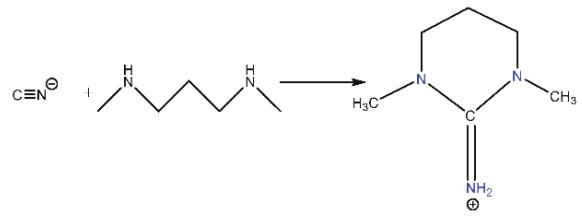

Perhaps the reaction involves a $\mathrm{Cu}^{\mathrm{I}} / \mathrm{Cu}^{\mathrm{II}}$ cyanide system as catalyst-the faint blue color of the solutions during slow formation of the product indicated some $\mathrm{Cu}^{\mathrm{II}}$ being present, presumably from air-oxidation. The central $\mathrm{CN}_{3}$ group of the guanidinium cation is rigidly planar, and the $\mathrm{C}-\mathrm{N}$ bond lengths average 1.318(7) $\AA$, which is close to the expected value. For example, the average $\mathrm{C}-\mathrm{N}$ distance in a series of some 50 structures containing the guanidinium cation $\mathrm{CH}_{6} \mathrm{~N}_{3}{ }^{+}$[9] is $1.321 \AA$. There does not appear to be any significant hydrogen-bonding or other intermolecular interaction between the guanidinium cations and the anionic sheets. The thermal ellipsoids in Figure 1 imply rigid body vibration is occurring about an axis perpendicular to the plane of the molecule, a vibration that would be hampered if the iminium group were involved in significant hydrogen bonding.

\subsection{Thermal Gravimetric Analysis}

On heating a sample of 1 under nitrogen at $50{ }^{\circ} \mathrm{C} / \mathrm{min}$ to $600{ }^{\circ} \mathrm{C}$, the sample suffered a $38 \%$ mass loss by $300{ }^{\circ} \mathrm{C}$, and then further losses in a complex fashion as the mass tended towards the $38 \%$ expected for residual $\mathrm{CuCN}(\mathrm{s})$; see Figure 3a. Similarly, a sharp drop in mass of $38 \%$ was observed when separate samples were heated rapidly to $225^{\circ} \mathrm{C}$ or to $275{ }^{\circ} \mathrm{C}$ (Figure $3 \mathrm{~b}$ ) and held at those temperatures for an hour and a half, during which there was only $1-2 \%$ further loss.

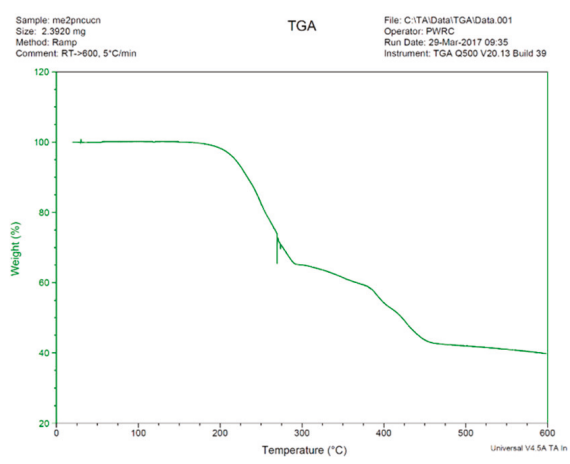

(a)

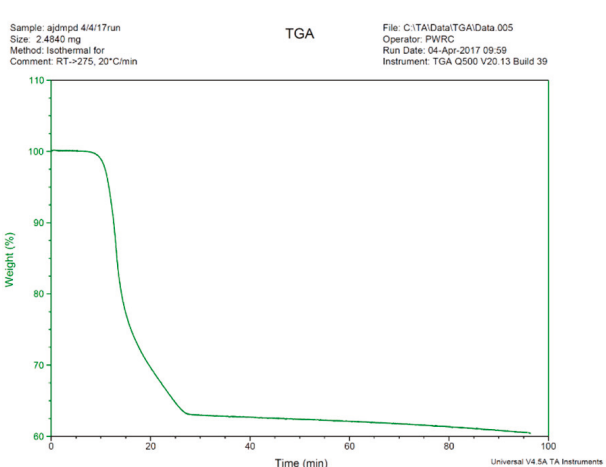

(b)

Figure 3. Thermal gravimetric analysis for 1 : (a) $0-600{ }^{\circ} \mathrm{C}$ at $50{ }^{\circ} \mathrm{C} / \mathrm{min},\left(\right.$ b) $0-275^{\circ} \mathrm{C}$ at $20^{\circ} \mathrm{C} / \mathrm{min}$ and hold $90 \mathrm{~min}$.

Since the molar mass of $[\mathrm{LH}]\left[\mathrm{Cu}_{2}(\mathrm{CN})_{3}\right.$ where $\mathrm{L}$ is the guanidine base is $333.3 \mathrm{u}$, the $38 \%$ mass loss corresponds to a loss of $127 \mathrm{u}$, suggesting that the guanidinium cation in $\mathbf{1}$ loses a proton to form the cyclic guanidine $\mathrm{L}$, with mass $127 \mathrm{u}$, which is then released. If the cation were the expected protonated dimethylpropanediamine, the mass loss would have been very different. The nature of the remaining solid at 225 or $275^{\circ} \mathrm{C}$ is not clear. In similar experiments with an $\mathrm{N}$-methylethanolamine complex [10], the sample lost methylethanolamine and $\mathrm{HCN}$ gas separately at $20{ }^{\circ} \mathrm{C}$ to leave behind $\mathrm{CuCN}$, but the $\mathrm{CuCN}$ in the present case is not formed until much higher temperatures. 


\subsection{Spectroscopy and Analyses}

The infrared spectrum of 1 shows strong absorptions at $2110 \mathrm{~cm}^{-1}(\mathrm{C} \equiv \mathrm{N}$ stretch) and 3406 and $3497 \mathrm{~cm}^{-1}$ (N-H stretch). As expected, the $\mathrm{C} \equiv \mathrm{N}$ stretches are close to those observed in similar compounds. The N-H stretching frequencies are shifted from values in the region $3100-3200 \mathrm{~cm}^{-1}$ found in a number of similar network solids we have made containing protonated amines. Data on infrared data on iminium cations in the literature are sparse, but reference [8] gives $\mathrm{N}-\mathrm{H}$ frequencies at $3427(\mathrm{~s}), 3325(\mathrm{~m})$, and $3268(\mathrm{~m}) \mathrm{cm}^{-1}$ for the unsubstituted guanidinium cation. A lower value of $3115 \mathrm{~cm}^{-1}$ was quoted for the asymmetric N-H stretch in methyl formimidate hydrochloride [11], but the author commented that the low value was likely due to strong N-H ... Cl hydrogen-bonding. We synthesized the hydrochloride salt of 1,1,3,3-tetramethylguanidine, 2, by titration of this base with $\mathrm{HCl}$, since the iminium group in this salt should have a similar molecular environment to the iminium cation in 1. The N-H stretches found for 2 were 3107 and $3281 \mathrm{~cm}^{-1}$. The significant differences in $\mathrm{N}-\mathrm{H}$ frequencies for $\mathbf{1}$ and the model compound 2 perhaps again reflect $\mathrm{N}-\mathrm{H} \ldots \mathrm{Cl}$ hydrogen bonding in 2 compared with the lack of hydrogen bonding to the iminium group in $\mathbf{1}$. The presence of the host CuCN network could also affect the IR spectrum of $\mathbf{1}$.

Elemental analysis of 1 gave $32.59 \% \mathrm{C}, 3.68 \% \mathrm{H}$ and $25.19 \% \mathrm{~N}$, which are comparable with the values calculated for the new product, $\mathrm{C}_{9} \mathrm{H}_{14} \mathrm{Cu}_{2} \mathrm{~N}_{6}-32.43 \% \mathrm{C}, 4.23 \% \mathrm{H}$ and $25.22 \% \mathrm{~N}$, and differ significantly from values of $31.06 \% \mathrm{C}, 5.21 \% \mathrm{H}$ and $22.64 \% \mathrm{~N}$ calculated for the expected product $\mathrm{C}_{8} \mathrm{H}_{16} \mathrm{Cu}_{2} \mathrm{~N}_{5}$, which would have contained the conjugate acid of the dimethyldiaminopropane. Further confirmation of the presence of the guanidinium cation in $\mathbf{1}$ was found in the density of the crystals, which was found by flotation methods to be $1.692(8) \mathrm{g} / \mathrm{cm}^{3}$, the same as the value of $1.698 \mathrm{~g} / \mathrm{cm}^{3}$ calculated from the X-ray data for 1.

\section{Experimental}

Crystal Data for $\mathrm{C}_{9} \mathrm{H}_{14} \mathrm{Cu}_{2} \mathrm{~N}_{6}(\mathrm{M}=333.34 \mathrm{~g} / \mathrm{mol})$, crystals cut from colorless rods, monoclinic, space group $\mathrm{P} 21 / \mathrm{c}($ no. 14$), \mathrm{a}=8.5598(14) \AA, \mathrm{b}=14.825(4) \AA, \mathrm{c}=10.853(2) \AA, \beta=108.570(13)^{\circ}, \mathrm{V}=1305.5(5) \AA^{3}$, $\mathrm{Z}=4, \mathrm{~T}=300(2) \mathrm{K}, \mu(\mathrm{MoK} \alpha)=3.249 \mathrm{~mm}^{-1}, \mathrm{D}_{\text {calc }}=1.698 \mathrm{~g} / \mathrm{cm}^{3}, \mathrm{D}_{\text {meas }}=1.692(8) \mathrm{g} / \mathrm{cm}^{3}$, 21,730 reflections measured from four crystals $\left(2.4^{\circ} \leq \Theta \leq 27.67^{\circ}\right.$, cell dimensions averaged from the four crystals), 3009 unique $\left(R_{\text {int }}=0.052\right)$, which were used in all calculations. The final $R_{1}$ was $0.0340(\mathrm{I}>2 \sigma(\mathrm{I}))$ and $\mathrm{wR}_{2}$ was 0.0951 (all data) for 166 variables. The structure was solved by the heavy atom method from a Patterson map calculated with SHELXS and refined with SHELXL Version 2017 [12]. The CN groups were modeled with 50\% disorder in their orientation, and a disordered model was also used for two of the three propane $\mathrm{C}$ atoms, with restraints on the geometry and temperature factors for atoms at alternative sites; refined occupancies for the $\mathrm{A}$ and $\mathrm{B}$ occupancies were $65(1) \%$ and $35(1) \%$. Hydrogen atoms were constrained at idealized positions, riding on the carbon atoms, with $\mathrm{C}-\mathrm{H}$ distances of $0.96 \AA$ for methyl groups and $0.97 \AA$ for methylene groups, and isotropic temperature factors were $50 \%$ larger than the $\mathrm{U}_{\mathrm{eq}}$ of the bonded $\mathrm{C}$ atoms. Attempts to refine the iminium $\mathrm{H}$ atoms were not successful, so they too were constrained in ideal positions, with $\mathrm{N}-\mathrm{H}$ distances of $0.86 \AA$, and $\mathrm{U}_{\text {iso }}$ was again $50 \%$ of the $\mathrm{U}_{\text {eq }}$ of the $\mathrm{N}$ atom. The cif file for this structure is included in the Supplementary Material for this article and has also been deposited with the Cambridge Crystallographic Data Center as CCDC 2035041. These data can be obtained free of charge via http://www.ccdc.cam.ac.uk/conts/retrieving.html (or from the CCDC, 12 Union Road, Cambridge CB2 1EZ, UK; Fax: +44 1223 336033; E-mail: deposit@ccdc.cam.ac.uk).

\section{Discussion}

This study shows that an unexpected reaction between cyanide ion and $N, N^{\prime}$-dimethyl-1,3-diaminopropane occurred to form a cycle guanidinium cation under the preparative conditions used. We have not found reference elsewhere to the preparation of this cation or to the conjugate base. When syntheses were carried out at lower $\mathrm{pH}$ values, a different crystalline 
product was obtained, for which X-ray diffraction analysis showed an anionic 3D CuCN network, not $2 \mathrm{D}$, as in this case, the expected protonated diamine was a guest, rather than the guanidinium cation found in the present work. This work will be published elsewhere. Further studies will explore the conditions favoring the reaction described here, and a possible mechanism.

\section{Materials and Methods}

Chemicals were used as obtained from suppliers without further purification. Chemical analysis was performed by Robertson Microlit (Ledgewood, NJ, USA). FTIR data were obtained with a Nicolet iS50 FT-IR spectrometer (Thermo Fisher Scientific, Waltham, MA, USA), and thermal gravimetric analyses were carried out under nitrogen with a TGA-Q500 instrument (TA Instruments, New Castle, DE, USA). The X-ray structure was determined with diffraction data collected with a Nonius Kappa CCD system (Bruker Axis LLC, Madison, WI, USA) using graphite monochromated MoK $\alpha$ radiation with $\lambda=0.7107 \AA$.

Supplementary Materials: The following are available online. Figure S1: Checkcif Report, Table S1: MOL File, Table S2: cif file, Figure S2: Infrared spectrum of title compound.

Author Contributions: P.W.R.C.: Designed the experiments, carried out the X-ray analysis, analyzed the results and wrote the manuscript. J.R.D.: Carried out the syntheses, thermal analyses, infrared spectra, and the preparation and infrared spectrum of tetramethylguanidinium chloride, 2. All authors have read and agreed to the published version of the manuscri.

Funding: This research received no external funding.

Acknowledgments: We gratefully acknowledge support from the chemistry department at Fordham University. We thank Emma Cleary, Patricia Luzuriaga, Joseph Michalski and Michelle Ngo and Arjun Sharma for assistance with density measurements and IR spectra, and Richard Kirchner for fruitful discussions.

Conflicts of Interest: The authors declare no conflict of interest.

\section{References}

1. Xu, H.; Zhou, B.-Y.; Yu, K.; Su, Z.-H.; Zhou, B.-B.; Su, Z.-M. Copper cyanide polymers with controllable dimensions modulated by rigid and flexible bis-(imidazole) ligands: Synthesis, crystal structure and fluorescence properties. CrystEngComm 2019, 21, 1242-1249. [CrossRef]

2. Nicholas, A.D.; Bullard, R.M.; Wheaton, A.M.; Streep, M.; Nicholas, V.A.; Pike, R.D.; Patterson, H.H. Synthesis and Luminescence of Optical Memory Active Tetramethylammonium Cyanocuprate(I) 3D Networks). Materials 2019, 12, 1211. [CrossRef] [PubMed]

3. Grifasi, F.; Priola, E.; Chierotti, M.; Diana, E.; Garino, C.; Gobetto, R. Vibrational-Structural Combined Study into Luminescent Mixed Copper(I)/Copper(II) Cyanide Coordination Polymers. Eur. J. Inorg. Chem. 2016, 18, 2975-2983. [CrossRef]

4. Shao, M.; Li, M.-X.; Wang, Z.-X.; He, X.; Zhang, H.-H. Structural Diversity and Vibrational Spectra of Nine $\mathrm{Cu}(\mathrm{I})$-Cyanide Metal-Organic Frameworks with in Situ Generated N-Heterocyclic Ligands. Cryst. Growth Des. 2017, 17, 6281-6290. [CrossRef]

5. Stocker, F.B.; Staeva, T.P.; Rienstra, C.M.; Britton, D. Crystal Structures of a Series of Complexes Produced by Reaction of Copper(I) Cyanide with Diamines. Inorg. Chem. 1999, 38, 984-991. [CrossRef] [PubMed]

6. Corfield, P.W.R.; Sabatino, A. Crystal structures of two mixed-valence copper cyanide complexes with N-methylethylenediamine. Acta Cryst. 2017, E73, 141-146. [CrossRef] [PubMed]

7. Corfield, P.W.R.; Stavola, T.J. Poly[diethylammonium tetra- $\mu_{2}$-cyanido- $\kappa^{8} C: N$-tricuprate(I)]] a two-dimensional network solid. IUCrData 2020, 5, x200968. [CrossRef]

8. Lin, S.-H.; Zhou, X.-P.; Li, D.; Ng, S.W. In Situ Formed Guanidinium Cations as Templates to Direct Fabrication of Honeycomb-like CuCN Networks. Cryst. Growth Des. 2008, 8, 3879-3881. [CrossRef]

9. Horner, M.J.; Holman, K.T.; Ward, M.D. Lamellae-Nanotube Isomerism in Hydrogen-Bonded Host Frameworks. Angew. Chem. Int. Ed. 2001, 40, 4045-4048. [CrossRef]

10. Koenigsmann, C.; Rachid, L.N.; Sheedy, C.M.; Corfield, P.W.R. Synthesis, decomposition studies and crystal structure of a three-dimensional $\mathrm{CuCN}$ network structure with protonated $\mathrm{N}$-methylethanolamine as the guest cation. Acta Cryst. 2020, C76, 405-411. [CrossRef] [PubMed] 
11. Spinner, E. The vibration spectra of the hydrochlorides of methyl formimidate and methyl acetimidate. Aust. J. Chem. 1966, 19, 2153-2157. [CrossRef]

12. Sheldrick, G.M. Crystal structure refinement with SHELXL. Acta Cryst. 2015, C71, 3-8.

Publisher's Note: MDPI stays neutral with regard to jurisdictional claims in published maps and institutional affiliations.

(C) 2020 by the authors. Licensee MDPI, Basel, Switzerland. This article is an open access article distributed under the terms and conditions of the Creative Commons Attribution (CC BY) license (http://creativecommons.org/licenses/by/4.0/). 
MDPI

St. Alban-Anlage 66

4052 Basel

Switzerland

Tel. +41616837734

Fax +41 613028918

www.mdpi.com

Molbank Editorial Office

E-mail: molbank@mdpi.com

www.mdpi.com/journal/molbank

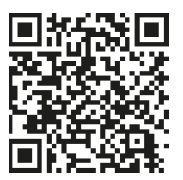



MDPI

St. Alban-Anlage 66

4052 Basel

Switzerland

Tel: +41 616837734

Fax: +41 613028918 